ing

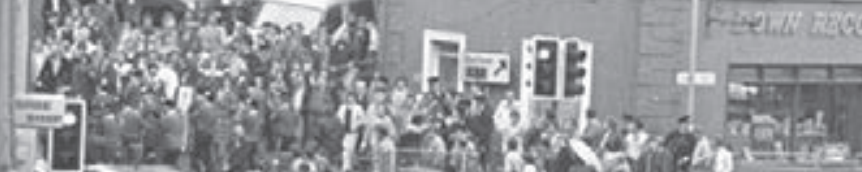

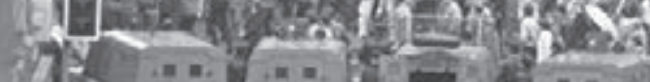

\title{
1
}

Ais:

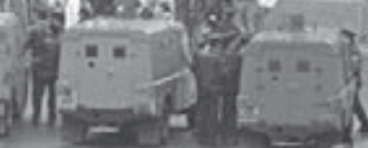

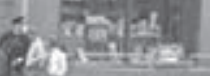

1

aris

BNist

In:

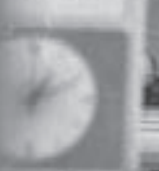

$H=1$

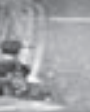

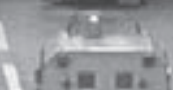
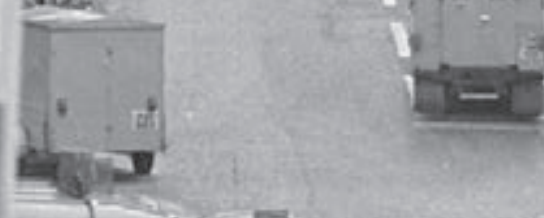

1)

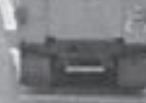

3
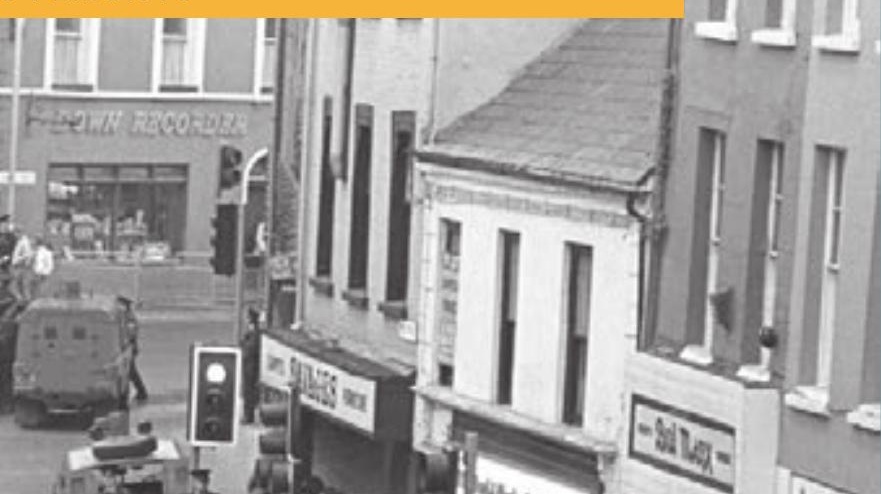

a nom 1
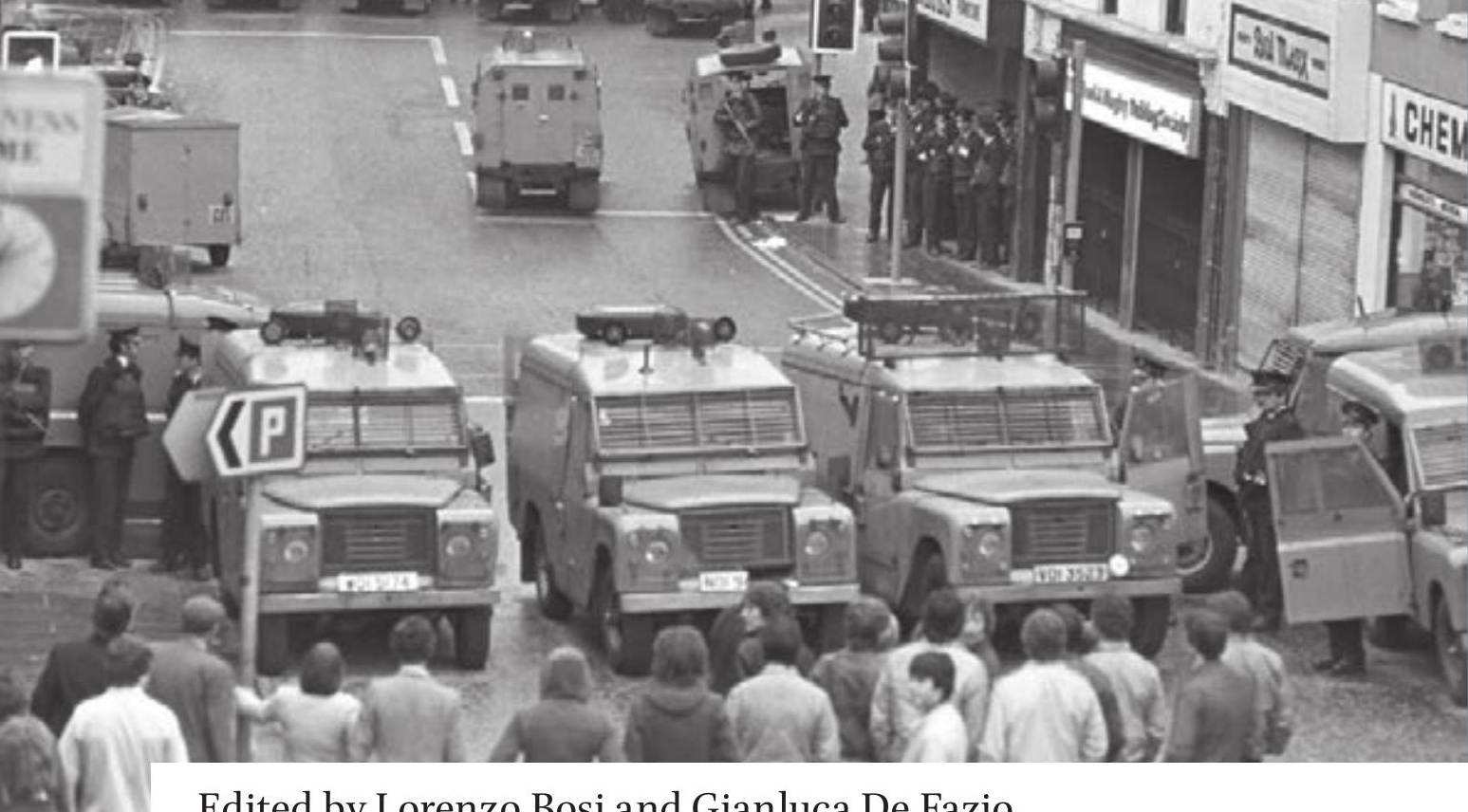

Edited by Lorenzo Bosi and Gianluca De Fazio

The Troubles in Northern Ireland and Theories of Social Movements

Amsterdam

University

Press 
The Troubles in Northern Ireland and Theories of Social Movements 


\section{Protest and Social Movements}

Recent years have seen an explosion of protest movements around the world, and academic theories are racing to catch up with them. This series aims to further our understanding of the origins, dealings, decisions, and outcomes of social movements by fostering dialogue among many traditions of thought, across European nations and across continents. All theoretical perspectives are welcome. Books in the series typically combine theory with empirical research, dealing with various types of mobilization, from neighborhood groups to revolutions. We especially welcome work that synthesizes or compares different approaches to social movements, such as cultural and structural traditions, micro- and macro-social, economic and ideal, or qualitative and quantitative. Books in the series will be published in English. One goal is to encourage nonnative speakers to introduce their work to Anglophone audiences. Another is to maximize accessibility: all books will be available in open access within a year after printed publication.

\section{Series Editors}

Jan Willem Duyvendak is professor of Sociology at the University of Amsterdam. James M. Jasper teaches at the Graduate Center of the City University of New York. 


\title{
The Troubles in Northern Ireland and Theories of Social Movements
}

\author{
Edited by \\ Lorenzo Bosi and Gianluca De Fazio
}


Cover illustration: Two rows of RUC Land Rovers keeping warring factions, the Nationalists (near the camera) and Loyalists, apart on Irish Street, Downpatrick. bho1o64

Bobbie Hanvey Photographic Archives (MS2001.039), John J. Burns Library, Boston College

Cover design: Coördesign, Leiden

Typesetting: Crius Group, Hulshout

Amsterdam University Press English-language titles are distributed in the US and Canada by the University of Chicago Press.

$\begin{array}{ll}\text { ISBN } & 978 \text { 90 } 89649591 \\ \text { e-ISBN } & 9789048528639 \text { (pdf) } \\ \text { DOI } & 10.5117 / 9789089649591 \\ \text { NUR } & 686\end{array}$

\section{(c) $\left(\mathrm{BP} \Theta_{\mathrm{NC}}\right.$}

Creative Commons License CC BY NC ND (http://creativecommons.org/licenses/by-nc-nd/3.o)

@ All authors / Amsterdam University Press B.V., Amsterdam, 2017

Some rights reserved. Without limiting the rights under copyright reserved above, any part of this book may be reproduced, stored in or introduced into a retrieval system, or transmitted, in any form or by any means (electronic, mechanical, photocopying, recording or otherwise). 
Dedicated to the memory of Bob Purdie 



\section{Table of Contents}

Acknowledgements

1 Contextualizing the Troubles

Investigating Deeply Divided Societies through Social Movements

Research

Lorenzo Bosi and Gianluca De Fazio

2 What Did the Civil Rights Movement Want?

Changing Goals and Underlying Continuities in the Transition from

Protest to Violence

Nialló Dochartaigh

3 Vacillators or Resisters?

The Unionist Government Responses to the Civil Rights Movement

in Northern Ireland

Erin-Beth Turner and Gianluca De Fazio

4 White Negroes and the Pink IRA

External Mainstream Media Coverage and Civil Rights Contention in

Northern Ireland

Gregory Maney

5 'We Are the People'

Protestant Identity and Collective Action in Northern Ireland, 1968-1985

Sarah Campbell

6 Ulster Loyalist Accounts of Armed Mobilization, Demobilization, and Decommissioning Neil Ferguson and James W. McAuley

7 Social Movements and Social Movement Organizations Recruitment, Ideology, and Splits

Robert W. White and Tijen Demirel-Pegg 
8 Movement Inside and Outside of Prison

The H-Block Protest

Denis O'Hearn

9 'Mother Ireland, Get Off Our Backs'

165

Republican Feminist Resistance in the North of Ireland

Theresa O'Keefe

10 'One Community, Many Faces'

185

Non-sectarian Social Movements and Peace-building in Northern

Ireland and Lebanon

John Nagle

11 The Peace People

203

Principled and Revolutionary Non-violence in Northern Ireland Lee A. Smithey

Afterword

Social Movements, Long-term Processes, and Ethnic Division in Northern Ireland Joseph Ruane and Jennifer Todd

List of Authors

Index

\section{List of Tables and Figures}

Table 3.1 Predicted Responses to Movement Actions

Figure 7.1 Heuristic Model

Figure 8.1 Layout of an H-Block in Long Kesh prison 


\section{Acknowledgements}

This volume began as we were developing our own interest on the Troubles in Northern Ireland from a social movement perspective. This common denominator contributed to our first exchange of emails as far back as 2005 and to our subsequent meetings in Italy and in the United Kingdom. It was more recently that we saw the opportunity to develop a co-edited book on the topic, considering that a growing number of scholars were applying social movement theories to investigate and understand the Troubles. We share the belief that this growing literature is relevant not only for those who study this extraordinary case, and that these studies are important to further challenge social movement theories as well.

We thank all the authors represented in this volume for their commitment to this project and for their patience with the several rounds of reviews advanced by the editors, as well as external reviewers. To James M. Jasper and Jan Willem Duyvendak, co-editors of Amsterdam University Press' Protest and Social Movements series, we are grateful for their enthusiastic support and constructive criticism, which helped us to further develop and complete this book. Finally, we wish to thank Vanessa de Bueger and Kristin DeMint Bailey and the editorial staff in charge of handling our project at Amsterdam University Press.

Lorenzo Bosi and Gianluca De Fazio

September 2016 



\title{
1 Contextualizing the Troubles
}

\author{
Investigating Deeply Divided Societies through Social \\ Movements Research
}

\section{Lorenzo Bosi and Gianluca De Fazior}

The sheer scale and duration of Northern Ireland's 'Troubles', with 3530 people killed (1840 civilians) and 47,500 injured, between 1969 and 1998, make this conflict as one of the most lethal episodes of contention in postwar Western Europe. This volume relies on social movement research to challenge the exceptional character that has been often attributed to this conflict in the past. At the same time, it asks how research on the Troubles might inform future research on social movements beyond the Northern Ireland case. Despite the increasing importance of ethnonationalist conflicts in the post-Cold War period (Wimmer 2013; Muro 2015), social movement scholars have paid little attention to deeply divided societies (notable exceptions include: Cirulli and Conversi 2010; Cowell-Meyers 2014; Demirel-Pegg, forthcoming; Gorenburg 2003; Khawaja 1995; Martheu 2009; Melucci and Diani 1992; Norwich 2015; Olzak and Olivier 1998; Seidman 2000, 2011; Touquet 2015; Vladisavljevic 2002; Watts 2006), preferring instead to focus on 'stable', Western democracies (McAdam, Tarrow, and Tilly 2001). This book aims to at least partially address this gap by presenting stateof-the-art social movement research on the Northern Ireland's Troubles.

All societies are traversed by divisions, whether based on ethnicity, religion, race, class, or any combination of these and other factors. These fractures tend to exhibit varying degrees of intensity, resiliency, and politicization and are subject to historical and geographical fluctuations. Deeply divided societies are characterized by cleavages that are not pacified, as well as by the widespread belief that the state is actively taking the side of one of the parts in conflict. Regardless of its accuracy, this interpretation of the state acting in favour of a portion of society, rather than for all its citizenry, creates the potential for sociopolitical conflict and deepens its latent virulence, since the legitimacy of the state is ultimately questioned. In this dynamic, the dominant group 'appropriates

1 We would like to thank Devrashee Gupta, James Jasper, Niall Ó Dochartaigh, Joseph Ruane, Lee Smithey, Jennifer Todd, and Robert White, as well as the AUP reviewers, for their thoughtful comments on a previous draft of this chapter. 
the state apparatus and shapes the political system, public institutions, geography, economy and culture' (Yiftachel and Ghanem 2004:650). Thus, in deeply divided societies, subcultural divisions based on antagonized sociopolitical cleavages lead to regimes lacking full legitimacy, a propensity to widespread political violence, and state repression (Nordlinger 1972; Guelke 2012). The Northern Ireland case is a prototypical example of a society deeply divided along an ethnonational cleavage, similar to cases like Cyprus, South Africa, Israel, Lebanon, Iraq, Sudan, Congo, Pakistan, and the former Yugoslavia, among many others. This volume addresses this under-researched domain of cases by focusing on a number of key related questions: How does non-violent mobilization emerge and persist in deeply divided societies? What are the trajectories of participation in violent groups in these societies? What is the relationship between overt mobilization, clandestine operations, and protests among political prisoners? What is the role of media coverage and identity politics? Can there be non-sectarian collective mobilization in deeply divided societies? The answers to these questions do not merely try to explain contentious politics in Northern Ireland; instead, they tackle key issues in contemporary social movement scholarship debates.

In this introduction, we first discuss the main theoretical approach typically used to study deeply divided societies and then suggest how social movement studies may enrich and complement our understanding of the dynamics of contentious politics in these contexts. We examine the existing social movement scholarship on this case and then provide a brief discussion of Northern Ireland's historical context. Finally, we situate each chapter of the volume within the social movement field and emphasize their unique contributions to the Northern Ireland case.

\section{Contentious Politics in Deeply Divided Societies}

While not all deeply divided societies are split along ethnic or national cleavages, the ethnonational perspective has been the most prominent one applied to these cases. The ethnonationalism approach argues that, when in a single territory competing ethnic communities 'want their state to be ruled by their nation, or [...] want what they perceive as 'their' state to protect their nation' (McGarry and O'Leary 1995: 354), ethnonational conflict is likely. Ethnonational communities and their political organizations (violent or non-violent) are at the core of ethnic conflict and the main source of political violence and antagonism. 
For all its descriptive power, however, the ethnonationalist perspective suffers from its reductionist view of what constitutes ethnic communities. Sociologists like Rogers Brubaker have warned against 'the seemingly obvious and uncontroversial point that ethnic conflict involves conflict between ethnic groups' (2002: 166). By interpreting ethnonationalist conflict as a conflict between ethnonationalist groups, scholars have in fact fallen into the trap of 'groupism', or the reification of ethnonationalist groups as if they were monolithic collective actors with distinct, undisputed interests and agency, which statically respond to environmental stimuli (Brubaker 2002: 164-167). ${ }^{2}$ This reduces choice in the face of structural and historical inexorability. The ethnonational approach claims that fixed ethnic identities and ethnic antagonism are the main cause of ethnic violence (i.e. initial conditions). Yet, this is a static and over-deterministic account of conflict, in that it mainly indicates the pre-existing conditions for ethnic contention, but not how and when violence deemed as ethnic-based erupts in certain contingent historical contexts. This has led scholars to underemphasize some specific characteristics of mobilization:1) the trajectory of ethnonationalist mobilizations, their emergence, development, and decline; 2) the intramovement competition and conflict within heterogeneous ethnonationalist groups; and 3) the emergence of new groups and identities that transcend hardened ethnonationalist boundaries.

To understand and explain episodes of ethnic conflict and violence, like the outbreak and trajectory of the Troubles in Northern Ireland, it is thus necessary to theoretically unpack historical processes of popular mobilization and state reactions (Tilly 1978, 2003). It is through these collective processes that certain social boundaries and identities can be created and/ or activated and transformed, leading conflict and political violence to be framed as ethnic (or ethnonational) (Tilly 2004). Ethnonational categories were certainly central in Northern Ireland's own foundation in 1920. Thus, when in the late 1960 s mass protests demanding civil rights against unionist discriminatory rule were met by violent loyalist counter-protests and heavy state repression, all of this re-activated these pre-existing categories as the most salient organizing principle of Northern Ireland's contentious politics. The magnification of ethnonational identities solidified the deep divisions between the different factions appealing to opposite ethnonational claims, ultimately radicalizing their repertoires of contention (De Fazio 2013). As Brubaker and Laitin (1998: 426) pointed out, 'even where

2 For a critique of the 'essentialist' tendencies of ethnonational interpretations of the Troubles, see Ruane and Todd (2004). 
violence is clearly rooted in preexisting conflict, it should not be treated as a natural, self-explanatory outgrowth of such conflict, something that occurs automatically when the conflict reaches a certain intensity'. The transition from structural causes to effects is not automatic and we need to take into account agency as well.

Undeniably, the Irish Republican Army (IRA) had attempted, since the Partition, to overthrow the unionist government through several armed insurgencies (1942-1944; 1956-1962). Nevertheless, these insurgent campaigns were routinely crushed by police repression and lack of support by the Irish Catholic minority, the alleged ethnonational community that the IRA intended to vindicate. Conversely, soon after the Troubles erupted, the IRA was able to garner significant political and social support among many Irish Catholics in vast areas of Northern Ireland. Rather than assuming that the popular support of radical ethnonational claims and repertoires was the obvious and direct product of ethnonational identities, we have to explain why radical contentious claims and repertoires gained support at a particular juncture in Northern Ireland history (for instance, see English 2009: 85-86; White 1989). If the civil rights movement had not gone down to streets politics, or if the unionist establishment had provided a concrete answer to the civil rights demands, then the Troubles might have never happened. Current interpretations of the Troubles as an ethnonationalist conflict are static descriptions that cannot explain why an ethnonational conflict breaks out in a certain historical moment (if it emerges at all), or why the conflict follow the trajectory it does.

In this volume, we argue that recent developments in social movement theories (entailing an actor-based approach and the contextualization of contentious politics) provide a dynamic theoretical framework able to look at the Troubles and, more generally, at conflicts in deeply divided societies as the result of ongoing relational processes. The social movement field has grown rapidly over the last 40 years in both empirical research and theoretical analysis (Snow, Klandermans, and Soule 2004; Della Porta and Diani 2015). As Della Porta and Diani have suggested, this field of studies has focused 'around four main sets of questions, concerning (a) the relationship between structural change and transformations in patterns of social conflict; (b) the role of cultural representations in enabling collective action; (c) the mechanisms that render it rational to mobilize on collective goals; and (d) the effects of the political and institutional context on social movements development and evolution' (Della Porta and Diani 2015:4).

Contemporary social movement research emerged, in the late 196os and early 1970s, in reaction to collective behaviour approaches, which described 
contentious politics as irrational, unorganized, spontaneous, mainly violent, and resulting as a consequence of important structural changes, such as modernization. Following such approaches, individuals who share grievances and generalized beliefs are driven into mobilization rather than willing to mobilize for their purposes. Resource mobilization theory challenged these early socio-psychological approaches and focused on rational actors, at their organizational capacities and resources (material, social-organizational, moral, human, and cultural), moving away from deprivation and grievances. Where social movement organizations are seen as enterprises, individuals are understood then as rational actors who strategically weigh the costs and benefits of alternative courses of action and choose the course of action deemed as most likely to maximize their concrete goals and interests. In the 1980s, new social movement scholars in Europe challenged collective behaviour studies through a social-constructivist perspective by focusing on identity, lifestyles, meanings, and beliefs as possible explanations for understanding social movements. Whereas resource mobilization theory was seeking to answer how collective action emerges, the new social movement approach looked to explain why mobilization happened. Meanwhile, in the United States, social-constructivists scholars started to investigate framing processes: how movements offer solutions to grievances and how movements provide the rationale needed to motivate support for collective action. This approach particularly focused on the role of cognitive, affective, and ideational roots of contention.

In the early 1980s, political process theories rapidly took an almost hegemonic position in the field, stressing that social movements are political rather than psychological phenomena, and that the political context of collective action and the political opportunities it provides (increased access to political decision-making power, instability in the alignment of ruling elites, access to elite allies, declining capacity and propensity of the state to repress dissent) are capable of mobilizing activism as well as decreasing it. These approaches, which have been criticized for being overly structural and static, have been joined by more dynamic ones: contentious politics (McAdam, Tarrow, and Tilly 2001; Tilly and Tarrow 2007), strategic interactions (Jasper 2007; Jasper and Duyvendak 2015; Duyvendak and Jasper 2015), and field theories (Fligstein and McAdam 2012), among others. While different schools of thought in the field exist, with competing concepts, paradigms, and priorities, it is important not to overstate such differences as the work of scholars who are usually associated with one or the other approach are in reality more complex and richer than assumed (Buechler 2011). 
Recent social movement theories challenge overly structural assumptions by recognizing the agency of all political actors participating to contention, from paramilitaries to state authorities and political parties, within their complex organizational fields, emphasizing their shifting strategies as they interact with each other and adapt to their context (Jasper 2004; Maney, McCarthy, and Yukich 2012; Jasper and Duyvendak 2015; Duyvendak and Jasper 2015). It is through the untangling of the ever-changing relationships between the main actors in the conflict, the transformation of their identities, goals, priorities, and tactics, that we can make sense of episodes of violent contention, such as the Troubles. Following this perspective, conflicts in deeply divided societies become de-exceptionalized and deessentialized, without the willingness to equate conflicts in deeply divided societies with conflicts in other types of societies. In looking for agency, social movement approaches are not arguing against structural explanations, but consider the complex interactions between agency and structure and are better able to underline the importance of societal structures in deeply divided societies, constraining and shaping players' choices. We believe that deeply divided societies are capable of showing more clearly how agency may unfold within certain historical structures/institutions/ conditions, and how this relationship changes across time and space (Bosi and Davis, forthcoming; Ruane and Todd, in this volume).

Our goal with this book is to advance our understanding of the Troubles, while also opening new avenues of research for social movement scholars interested in exploring conflict in deeply divided societies from a fresh perspective. We argue that the interactions between social movement actors and other political actors should be at the centre stage of contentious politics (Tilly 2008), and propose a perspective that contextualizes the emergence of political violence, the groups that embrace it, and those that eventually disengage from it (Bosi, Demetriou, and Malthaner 2014; Bosi, Ó Dochartaigh, and Pisoiu 2015). In bringing the analytical power of this perspective to a case of a deeply divided society, we believe that this volume looks as well at a future challenge that we have only started to address thus far. Recognizing that we can use social movement theories to study contentious politics in deeply divided societies, we are compelled to ask what are some of the unique challenges social movements face in these contexts.

Collective movements challenging political authorities, as well as structures of authority, assume a different meaning when they occur in deeply divided societies. In these societies the legitimacy of the political system and the rules of the game are contested, if not openly rejected, by a section of the polity. At the same time, structures of authority alternative to the 
state can be founded within ethnonationalist communities, as these represent 'composite emergent products of a long historical process whereby past successes in organising division lay the foundation for subsequent reproduction of community solidarity and identity' (Ruane and Todd, in this volume). Moreover, the emergence of antagonistic countermovements is far more likely in contexts where competing ethnic or national identities can be activated and made salient in a short period of time (Bob 2012). Political authorities do not have the luxury of ignoring these challenges, as might be the case in traditional liberal democracies; nor, can they simply act as neutral arbiter between conflicting movements. The opposite options of either granting concessions to challengers, or showing intransigence towards them, are both costly strategies for governments (Luders 2010), with outcomes that are hard to predict. In fact, political authorities in deeply divided societies are less likely to repress against the majority community if they need their support in order to maintain the status quo and stay in office (White 1999). Similarly, the policing of protest is not a routine, neutral public order task in a divided society; in the context of a state perceived as partial, if not outright hostile to certain groups, the impartiality and legitimacy of police as representative and enforcer of that state is intrinsically called into question (De Fazio 2007; Guelke 2012). Under certain political, social, and historical conditions, political violence is an option not too far removed from the realm of possibilities in deeply divided societies, where institutional mechanisms for accommodating grievances are missing or underdeveloped. In deeply divided societies, the establishment may oppose the inclusion of certain groups (not necessarily a minority group, as the case of South Africa's apartheid suggests) and do not provide legitimate channels for regime opponents to voice their discontent in non-violent ways. Once political violence, be it state-sanctioned, coming from clandestine organizations, protesters, or vigilante groups, enters into the equation of contentious politics, the search for peaceful solutions becomes increasingly more difficult. Where mobilization does not directly confront the political authorities, but is instead willing to counter deeply entrenched divisions and sectarianism, what is indirectly challenged are the structures of authority on which different players are drawing their legitimacy (this was the case of the Peace People in Northern Ireland, see Smithey, in this volume). These types of mobilizations are capable of generating cross-cutting solidarities and divisions across well-established cleavages (Diani 2000); some movements may be directly attempting to radically transform ethnonational identities, while others embrace pluralist politics to emphasize non-ethnic claims, 
such as LGBT rights (see Nagle's chapter on these types of mobilizations in Northern Ireland and Lebanon).

\section{The Northern Ireland Context and the Troubles}

When Great Britain partitioned Ireland into two separate entities, six counties in the north-eastern historical region of Ulster remained under British rule (Northern Ireland), while the Irish Free State was established in the south. The new province of Northern Ireland was created so that the Protestants loyal to the British Crown, about two-thirds of the local population, could retain their political and cultural union with the United Kingdom. The remaining one-third of the population, the Irish Catholics, instead identified politically and culturally with what would later become the Republic of Ireland in the south. Northern Ireland was thus established as a semi-autonomous province within the United Kingdom, with its own parliament (Stormont), local government, judicial system, and, most importantly, full responsibility for internal security and public order.

Stormont represented the symbolic site where unionist domination over the Irish Catholic minority was created, reproduced, and executed (Ruane and Todd 1996). The Northern Ireland regime basically embodied a confessional state with institutionalized partiality, without the necessary checks and balances to limit systemic excesses and biases and no oversight from the central British government. The latter, in fact, rarely showed interest towards Northern Ireland politics and avoided interfering with what was perceived as a peripheral and troublesome region of the United Kingdom (Rose 1971).

In the aftermath of World War II and with the expansion of the British welfare state, a group of activists in the mid-196os decided to tackle housing, job, and electoral practice discrimination in Northern Ireland by borrowing the rhetoric of the Civil Right Movement in the United States, but, at least initially, not its direct action approach. The reformist goals of the Northern Ireland civil rights movement (CRM) was to outlaw institutional discrimination through a political and legal campaign geared to highlight the unfairness of the political system in the region, especially in comparison with the democratic standards adopted in the rest of the United Kingdom. One of the tactics of the CRM was to provoke Westminster to intervene by pressuring Stormont to put an end to widespread discrimination. In 1968 , the growing frustration with the inability of the unionist government to deliver significant reforms, the encouraging example of the civil 
rights mobilization in the United States, and the closed channels for legal mobilization finally convinced some within the CRM leadership to redirect their efforts towards direct action. Transgressive tactics of non-violent civil disobedience and demonstrations were deemed as more effective weapons in the struggle for civil rights (Purdie 1990).

On 5 October 1968, the unionist Minister of Home Affairs banned a civil rights march planned to take place in Derry, claiming public order reasons; the Royal Ulster Constabulary (RUC) eagerly enforced the ban with excessive and indiscriminate use of force against peaceful marchers as well as bystanders. Police violence against the CRM transformed an otherwise minor protest into a 'transformative event'; the images of police brutality, reminiscent of tactics used against civil rights demonstrations in the US South, rapidly spread throughout the world. A wave of mass civil rights demonstrations had just started, immediately colliding with the dominant majority community and 'its' institutions. In a few months, this sociopolitical crisis opened up the space, first, for extreme communal violence during the summer of 1969; second, for the deployment of the British Army in the streets of Belfast and Derry to restore law and order; third, for the emergence of the Provisional IRA at the end of 1969 , as an answer to loyalist mobs and to the degeneration in the relationship between the British Army and the local residents in Catholic working-class neighbourhoods (Ó Dochartaigh 2005). The deterioration of the situation brought to an end the Stormont regime in March 1972, when Westminster instituted Direct Rule, but violence did not stop for another quarter of a century. In the mid-1970s, a peace movement brought together Catholic and Protestant moderates, but with no success.

The decline of the armed conflict option originated in the early 1980s, when the efficacy of the armed struggle was first questioned and little by little progressed in the next two decades, following the decision of the Provisional IRA leadership, through the role played by Sinn Féin, to participate in the peace process (Bean 2007). After the failures of the Sunningdale experiment (1973) - brought down by the loyalist workers' strike of 1974 - and of the Anglo-Irish Agreement (1985), the Good Friday Agreement (1998) finally created a devolved government in a power-sharing executive supported from both communities (Ó Dochartaigh 2016). However, this has not signified a complete solution to the conflict, as some dissident republican militant groups have not accepted the agreement and refuse to abandon the armed struggle (Evans and Tonge 2012), as well as was the case with the flag dispute in 2012 and the role of loyalist fringes (Ruane 2017). The recent vote of the United Kingdom to exit the European Union, with the majority of Scotland and Northern Ireland voting to remain, might trigger 
a new resurgence of contention over Irish unity, which might destabilize the young post-agreement institutions.

\section{Social Movement Research in Northern Ireland}

Before the turn of the millennium, relatively few scholars engaged with social movement theories to study the Troubles in Northern Ireland. In 1985, John Hannigan's research investigated dilemmas of strategy and ideology within the Provisional IRA, using resource mobilization theories and a political process approach, probably one of the earliest social movement pieces on the Troubles. However, it was Robert W. White who systematically brought social movement theories into his research on the Irish republican movement (1989, 1992, 1993, 1999, 2007, 2010). In more than 20 years of academic research on the subject, White adopted the analytical tools typically used to study peaceful protest to investigate the micro-mobilization, commitment, and post-recruitment activism of the republican movement in Northern Ireland, reconstructing its contentious history and evolution over the course of the conflict. He did so by relying on resource mobilization and political process theories $(1989,1992,1993)$, as well as identity theories $(2007,2010)$, by conducting numerous intensive interviews with militant activists during and after the conflict. Moreover, he collected and analysed quantitative data on the victims and perpetrators of political violence, including state authorities, thus disaggregating the multiple factors behind the strategies of the various actors in the conflict. White's use of these original sources and social movement theories has provided alternative interpretations of the republican armed struggle campaign, in which the outbreak of the violent conflict is contextualized in the interaction between social movements, countermovements and the state. During the 1990s, two further authors adopted social movement theories to study the Northern Ireland Troubles, both from a comparative perspective. Cynthia Irvin (1999) innovatively used social movement theories to compare how armed groups change strategies and engage in institutionalized politics, in the often compared cases of the IRA in Northern Ireland and ETA in the Basque country. Diarmuid Maguire (1993) has instead compared the consequences of protest in Northern Ireland and Italy between 1967 and 1992, challenging the unexceptional character of the ethnonationalist conflict. Well before the growing interest in disengagement processes in the literature on political violence, Irvin's empirically rich work has investigated the strategic and organizational dilemmas faced by clandestine groups to 
give up armed struggle for participating in political institutions and has connected these shifts to a model which links the internal dynamics of the respective clandestine groups with changes in their external environment. Maguire's work has instead used the Northern Ireland case to challenge the naïve assumption that 'greater citizen protest lead inevitably to the introduction of reforms and the expansion of democracy' (1993: 103).

In the past fifteen years, a number of social movement scholars have used the Northern Ireland Trouble as a 'hard case' (Lijphart 1971) to investigate un-explored topics, or to challenge existing ones within the social movement field: the need to investigate transnational networks (Maney 2000); how social movements develop across time (Bosi 2006, 2011); paths from armed rebellion to peaceful activisms and vice versa (Maney 2007); pathways of activists mobilization across time (Bosi 2007, 2012; Bosi and Della Porta 2012; Bosi 2016c); the interaction between mobilization and repression (De Fazio 2007, 2009); new social movements in deeply divided societies (Nagle 2008, 2015; Hayes and Nagle 2016); territoriality and collective action (Ó Dochartaigh and Bosi 2010); countermovement mobilization in deeply divided societies (Smithey 2009, 2011; Smithey and Young 2010); relational dynamics and processes of radicalization (Alimi, Bosi, and Demetriou 2012; De Fazio 2013); legal opportunity and social movement strategy (De Fazio 2012); determinants of political violence against civilians (Maney, McCarthy, and Yukich 2012); within-movement competition (Maney 2012a; De Fazio 2014; Bosi and Davis, forthcoming); the paradox of reforms and processes of social movements institutionalization (Maney 2012b; Bosi 2016a); disengagement processes (Bosi 2013; Duhart 2016; Clubb 2016); and the contextualization of biographical outcomes (Bosi 2016b, 2016c, forthcoming).

While these scholars have used the Northern Ireland case to qualitatively extend social movement scholarship, the analytical power of this perspective also influenced other scholars outside of this circle, as they have increasingly adopted these frameworks to investigate the Troubles. For example, Graham Ellison and Greg Martin (2000) have questioned the assumptions contained in social movement research on policing, seeking their applicability to a deeply divided society such as Northern Ireland. Denis O'Hearn's study (2009) of protest by republican prisoners underlines how the dynamic interaction between protest and repression transformed political prisoners' culture, further investigating the key role of protest leaders in this process. Kevin Bean (2007) has studied the trajectory of the republican movement over the 30 years of conflict, relying on the social movement literature on processes of institutionalization. Christopher Farrington (2008) adopted a contentious politics approach to examine the 
role of unionist counter-mobilization and its interaction with the Northern Ireland state in facilitating the outbreak of the Troubles. Kevin Grisham (2014) compares the Provisional IRA with the Revolutionary Armed Forces of Colombia and the Abu Sayyaf Group, studying their transformation processes through a social movement analytical approach.

Another sign of the relative success of social movement scholarship in shaping the academic debate about Northern Ireland and the Troubles can be seen among several historians. The pioneering work by political historian Bob Purdie and his book Politics in the Streets (1990) put in the foreground the role of the civil rights movement, its strategies, allies, and antagonists in setting in motion the events leading to the Troubles. While not directly engaging with social movement theories, his rigorous scholarship and analytical focus on the emergence of the CRM and its unprecedented direct action campaign, prompted a new interest in the study of mass mobilization during the early years of the Troubles. There is hardly a social movement scholar studying Northern Ireland who does not hold an intellectual debt towards Bob Purdie and his endeavour to position processes of collective mobilization and the 'politics in the streets' of the late 196os at the heart of our understanding of Troubles. Later on, political historians like Niall Ó Dochartaigh and Richard English have more explicitly engaged with the social movement literature on mobilization and political violence. In their histories of local conflict in Derry (Ó Dochartaigh 2005) and the interaction between non-violent and violent politics in Northern Ireland (English 2009), they grapple with social movement concepts and scholarship, injecting key theoretical insights into their rich historical analyses.

\section{Volume Structure}

This volume explores the intersection of social movement scholarship and research on divided societies by inspecting the Troubles in Northern Ireland. It is divided into four sections, each one devoted to investigate from different theoretical and methodological perspectives a specific aspect of the Troubles, from the early years of the conflict, to the post-Good Friday Agreement period. In particular, the four sections will examine: 1) the civil rights years, with a focus on the civil rights movement and its political context; 2) unionist and loyalist contention, dealing with both peaceful collective action and violent strategies inside the Protestant community; 3 ) the republican movement, analysing its trajectory, from the recruitment and mobilization inside prisons, to the emergence of feminist republicanism; 
and 4) non-sectarian mobilizations, in which movements that do not and did not align with the ethnonational cleavage are examined. The chapters in the book have important theoretical and substantive implications for future research on social movements in divided societies and beyond.

The first section of the volume presents three chapters from Niall Ó Dochartaigh, Erin-Beth Turner and Gianluca De Fazio, and Gregory Maney. These opening chapters examine the relationship between the CRM and its larger political and media context. They grapple with how the evolution of the conflict shaped the movement goals, its logic of actions and policy impact, as well as with how the media representation of the movement frames affected the reputation and effectiveness of the movement. These chapters address key debates in social movement research on the formation of social movements, as well as their strategic interactions with authorities and the media. In Chapter 2, Ó Dochartaigh shows how, as the contentious context of the late 1960 s was shifting, so were the goals of the CRM. Adopting a contentious politics approach, Ó Dochartaigh examines protest and violence as being part of a continuum of contention, each one deeply related to the other. In particular, Ó Dochartaigh discusses the failure by the unionist government to implement its reform package promised in late 1968 as the catalyst for increased radicalization and potential for political violence. The very same Five-Point Reform package proposed by the unionist government is one of the main focuses of Erin-Beth Turner and Gianluca De Fazio's Chapter 3. Here they adopt Joseph Luders' (2010) lucid theoretical framework on the logic of social change, based on the rational calculation of disruption and concession costs by the targets of social movement actions, and apply it to the context of Northern Ireland. They show how, following a rational cost-evaluation by O'Neill's unionist government, only limited reforms could have been granted at that particular historical moment. At the same time, they also highlight some of the limitations of Luders framework and call for a more careful inspection of the role of ideology and emotions in the rational evaluations of policy formulations by social movement targets. In Chapter 4, Maney adds another important arena in the political equation of the civil rights years: mainstream international media. In particular, Maney explores the role of international coverage of the CRM in affecting its outcomes and the strategic responses by the unionist government, inserting another layer of complexity to the relational field.

The second section of the volume addresses a longstanding gap in the social movement scholarship on the Troubles: Protestant mobilization. While scholarship on the CRM in Northern Ireland has thrived in the last couple of decades, social movement research has paid only minor attention 
to unionist and loyalist mobilization. More generally, these chapters enrich the growing literature on the conditions for the emergence of countermovements and on disengagement from political violence. In Chapter 5 , Sarah Campbell addresses this gap by looking at the role collective memory and collective identity played in facilitating and galvanizing collective action in the Protestant community. In particular, Campbell traces the trajectory of Protestant mobilization from the reaction to the CRM in the late 196os, through the Ulster Workers' Council strike in 1974 that paralyzed Northern Ireland, up to the (ultimately failed) 'Ulster Says No!' campaign against the Anglo-Irish Agreement in 1985. In Chapter 6, Neil Ferguson and James W. McAuley explore the role of collective identity among loyalists in joining and later abandoning political violence. They analyse the narratives former loyalist paramilitaries exposed during in-depth qualitative interviews, in which they recount how they joined those organizations.

The third section of the volume zooms into the Irish republican movement from different historical and theoretical perspectives. In their respective chapters, Robert W. White and Tijen Demirel-Pegg, Denis O'Hearn, and Theresa O'Keefe examine the internal dynamics of the movement, as they deal with issues of recruitment from a longitudinal angle (White and Demirel-Pegg), the development of mobilization in the H-Block prison (O'Hearn), and the emergence and impact of radical feminism within republicanism in Northern Ireland (O'Keefe). All these chapters contribute to our understanding of the internal functioning of high-risk movements, from activists' differential motivations for participation, to conflicts over strategy and agenda setting. In Chapter 7 , White and Demirel-Pegg dissect the issue of recruitment within the larger republican movement through indepth interviews with activists who have joined the movement at different historical stages, some of them participating in the armed struggle. They explain the transformation of the Provisional IRA and Sinn Féin during the Troubles, as well as the emergence of post-Good Friday Agreement republican dissidents who refused to abandon political violence. In Chapter 8, O'Hearn explores the relationship between republican prisoners and the outside republican movement. In particular, O'Hearn explores how solitary confinement in the infamous H-Blocks produced solidarity and facilitated the unlikely emergence of protest within a total institution such as prison. The analysis focuses specifically on the interaction between the successes of protest inside the H-Blocks (especially the 'blanketmen' protests against prison authorities) and the mobilizing capabilities of the movement outside (and vice versa). It also investigates the conflict inside the republican movement, as the external leadership tried to control and 
direct the protests inside the H-Block, without success. In Chapter 9, O'Keefe inspects an overlooked aspect of the republican movement: republican feminism. O'Keefe describes how the experience of conflict and violence among some republican women generated a unique, even radical form of feminism. In-depth interviews with women active in the republican movement, including some who engaged in political violence, detail how these women developed a feminist sense of self and a collective feminist identity. This collective identity nurtured a subversive politics of feminist resistance that challenged patriarchy both within republicanism and the wider Irish society.

The fourth and last section of the volume deals with movements that do not align with the traditional ethnonational divisions, thus operating from a non-sectarian platform. The two chapters from John Nagle and Lee A. Smithey directly address the issue of how the construction, maintenance, and transformation of collective identity affect social movements and their political context. In Chapter 10, Nagle compares non-sectarian social movements in Northern Ireland and Lebanon, two emblematic divided societies. Ethnic identities are obviously central organizing principles for contentious politics in these divided societies; however, activists' efforts to challenge these identities and provide alternative sources of mobilization are an extremely significant subject of study. Two types of non-sectarian mobilizations can be identified: transformationist movements that seek to transform ethnic identities, and pluralist ones that strive to make the society more receptive to alternative identities. Nagle argues that the power-sharing agreements that rule Northern Ireland and Lebanon are the main factors determining the predominance of one type of movement over the other. Chapter 11 by Smithey focuses on an explicitly non-sectarian movement active in Northern Ireland in the late 1970s: the Peace People movement. The study of the Peace People movement allows the investigation of the life cycle of a non-sectarian movement and the unique challenges it has to face by operating in the context of a deeply divided society. Contrarily to loyalist and republican movements, the Peace People movement adopted nonviolent praxes, countering all political violence and inciting the emergence of a non-sectarian, unifying identity for all Northern Ireland people.

All the chapters in this volume share the goal to explore the multifaceted nature of the Troubles through a social movement perspective. The analytical payoff of this rich theoretical perspective is to dissect the ethnonational divide in Northern Ireland, the societal structure within which contentious politics developed into the Troubles, while focusing on its actors, their strategies, identities, interactions, motivation, conflicts, and outcomes. 
Differently positioned within (or consciously outside) the ethnonational cleavage and its organizations and institutions, political actors at the micro, meso, and macro level interpreted their situations, estimated opportunities, threats, acted on them, while transforming themselves and the political system. Also, in this perspective political violence is not an intrinsic feature of certain groups or the inexorable product of social structures, but is a contested strategic option that can be perceived as palatable or even inevitable according to changing temporal or spatial circumstances. The ultimate contribution of the social movement approach, and we hope of this volume, is to illuminate how these messy and contradictory processes can unfold and inform contentious politics in Northern Ireland, as well as other intricate divided political contexts.

\section{Works Cited}

Alimi, Eitan, Lorenzo Bosi, and Chares Demetriou. 2012. 'Relational Dynamics and Processes of Radicalization: A Comparative Framework'. Mobilization 17.1: 7-26. Bean, Kevin. 2007. The New Politics of Sinn Féin. Liverpool: Liverpool University Press.

Bob, Clifford. 2012. The Global Right Wing and the Clash of World Politics. Cambridge: Cambridge University Press.

Bosi, Lorenzo. 2006. 'The Dynamics of Social Movement Development: Northern Ireland's Civil Rights Movement in the 196os'. Mobilization 11.1: 81-100.

Bosi, Lorenzo. 2007. 'Social Movement Participation and the "Timing" of Involvement: The Case of the Northern Ireland Civil Rights Movement'. In Research in Social Movements, Conflicts and Change, Volume 27, ed. Patrick G. Coy. Bingley: Emerald, 37-61.

Bosi, Lorenzo. 2011. 'From "British Rights" to "British Out": The Northern Ireland Civil Rights Movement between the 196os and Early 1970s'. In Protest Beyond Borders: Contentious Politics in Europe since 1945, ed. Hara Kouki and Eduardo Romanos. Oxford: Berghahn, 125-138.

Bosi, Lorenzo. 2012. 'Explaining Pathways to armed Activism in the Provisional IRA, 1969-1972'. Social Science History 36.3: 347-390.

Bosi, Lorenzo. 2013. 'Safe Territories and Political Violence: The Persistence and Disengagement of Violent Political Organizations'. Nationalism and Ethnic Politics 19.1: 80-101.

Bosi, Lorenzo. 2016a. 'Incorporation and Democratisation: The Long Term Process of Institutionalisation of the Northern Ireland Civil Rights Movement'. In The 
Consequences of Social Movements, ed. Lorenzo Bosi, Marco Giugni, and Katrin Uba. Cambridge: Cambridge University Press, 338-36o.

Bosi, Lorenzo. 2016b. 'Social Movements and Interrelated Effects: The Process of Social Change in the Post-Movement Lives of Provisional IRA Volunteers'. Revista Internacional de Sociología 74.1: e047. doi: http://dx.doi.org/10.3989/ ris.2016.74.4.047.

Bosi, Lorenzo. 2016c. Vite di Lotta Armata. Storie di Attivismo nella Provisional IRA. Roma: Carocci.

Bosi, Lorenzo. Forthcoming a. 'Contextualizing the Biographical Outcomes of Provisional IRA Former Activists: A Structure-Agency Dynamic'. In Activists Forever? The Long-Term Impacts of Political Activism in Various Contexts, ed. Olivier Fillieule and Erick Neveau. Cambridge: Cambridge University Press.

Bosi, Lorenzo, and Donagh Davis. Forthcoming. “What Is to Be Done?”: Agency and the Causation of Transformative Events in Ireland's 1916 Rising and 1969 Long March'. Mobilization.

Bosi, Lorenzo, and Donatella della Porta. 2012. 'Micro-mobilization into Armed Groups: The Ideological, Instrumental and Solidaristic Paths'. Qualitative Sociology 35: 361-383.

Bosi, Lorenzo, Chares Demetriou, and Stefan Malthaner, eds. 2014. Dynamics of Political Violence: A Process-Oriented Perspective on Radicalization and the Escalation of Political Conflict. Burlington: Ashgate.

Bosi, Lorenzo, Niall Ó Dochartaigh, and Daniela Pisoiu, eds. 2015. Political Violence in Context: Time, Space and Milieu. Colchester: ECPR Press.

Brubaker, Rogers. 2002. 'Ethnicity without Groups'. European Journal of Sociology 44.2: 163-189.

Brubaker, Rogers, and David Laitin. 1998. 'Ethnic and Nationalist Violence'. Annual Review of Sociology 24: 423-452.

Buechler, Steven. 2011. Understanding Social Movements: Theories from the Classical Era to the Present. London: Paradigm.

Cirulli, Adriano, and Daniele Conversi. 2010. 'Movimenti e conflitti etnoterritoriali: una introduzione'. Partecipazione e Conflitto 2: 5-14.

Cowell-Meyers, Kimberly. 2014. 'The Social Movement as Political Party: The Northern Ireland Women's Coalition and Campaign for Inclusion'. Perspectives on Politics 10.1: 61-80.

Clubb, Gordon. 2016. Social Movement De-radicalization and the Decline of Terrorism: The Morphogenesis of the Irish Republican Movement. London: Routledge.

De Fazio, Gianluca. 2007. 'Police Knowledge Revised: Insights from the Policing of the Civil Rights Movement in Northern Ireland'. In Research in Social Movements, Conflicts and Change, Volume 27, ed. Patrick G. Coy. Bingley: Emerald, $63-87$. 
De Fazio, Gianluca. 2009. 'Civil Rights Mobilization and Repression in Northern Ireland: A Comparison with the US Deep South'. The Sixties: AJournal of History, Politics and Culture 2.2: 163-185.

De Fazio, Gianluca. 2012. 'Legal Opportunity Structure and Social Movement Strategy in Northern Ireland and Southern United States'. International Journal of Comparative Sociology 53.1: 3-22.

De Fazio, Gianluca. 2013. 'The Radicalization of Contention in Northern Ireland, 1968-1972: A Relational Perspective'. Mobilization 18.4: 475-496.

De Fazio, Gianluca. 2014. 'Intra-Movement Competition and Political Outbidding as Mechanisms of Radicalization in Northern Ireland, 1968-1969'. In Dynamics of Political Violence: A Process-oriented Perspective on Radicalization and the Escalation of Political Conflict, ed. Lorenzo Bosi, Chares Demetriou, and Stefan Malthaner. Farnham: Ashgate, 115-136.

Della Porta, Donatella, and Mario Diani. 2015. Social Movements: An Introduction. New York: John Wiley \& Sons.

Demirel-Pegg, Tijen. Forthcoming. 'The Dynamics of the Demobilization of the Protest Campaign in Assam'. International Interactions. DOI: 10.1080/03050629.2016.1128430.

Diani, Mario. 2000. 'Simmel to Rokkan and Beyond: Towards a Network Theory of (New) Social Movements'. European Journal of Social Theory 3·4: 387-406.

Duhart, Philippe. 2016. 'Directing Disengagement: Movement Centralization, Coordination, and Credibility in the Irish and Basque Peace Processes'. European Journal of Sociology 57.1: 31-63.

Duyvendak, Jan Willem, and James M. Jasper, eds. 2015. Breaking Down the State: Protestors Engaged. Amsterdam: Amsterdam University Press.

Ellison, Graham and Greg Martin. 200o. 'Policing, Collective Action and Social Movement Theory: The Case of the Northern Ireland Civil Rights Campaign'. British Journal of Sociology 51.4: 681-699.

English, Richard. 2009. 'The Interplay of Non-violent and Violent Action in Northern Ireland, 1967-72'. In Civil Resistance \& Power Politics: The Experience of Non-violent Action from Gandhi to the Present, ed. Adam Roberts and Timothy Garton Ash. Oxford: Oxford University Press, 75-90.

Evans, Jocelyn, and Jonathan Tonge. 2012. 'Menace without Mandate? Is There Any Sympathy for 'Dissident' Irish Republicanism in Northern Ireland?' Terrorism and Political Violence 24.1: 61-78.

Farrington, Christopher. 2008. 'Mobilisation, State Crisis and Counter-Mobilisation: Ulster Unionist Politics and the Outbreak of the Troubles'. Irish Political Studies 23.4: 513-532.

Fligstein, Neil, and Doug McAdam. 2012. A Theory of Fields. New York: Oxford University Press. 
Gorenburg, D.P. (2003). Minority Ethnic Mobilization in the Russian Federation. New York: Cambridge University Press.

Grisham, Kevin E. 2014. Transforming Violent Political Movements: Rebels Today, What Tomorrow? Abingdon: Routledge.

Guelke, Adrian. 2012. Politics in Deeply Divided Societies. London: Polity.

Hannigan, John A. 1985. 'The Armalite and the Ballot Box: Dilemmas of Strategy and Ideology in the Provisional IRA' Social Problems 33.1: 31-40.

Hayes, Bernadette, and John Nagle. 2016. 'Ethnonationalism and Attitudes towards Gay and Lesbian Rights in Northern Ireland'. Nations and Nationalism 22.1: 20-41.

Irvin, Cynthia. 1999. Militant Nationalism: Between Movement and Party in Ireland and the Basque Country. Minneapolis: University of Minnesota Press.

Lijphart, Arend. 1971. 'Comparative Politics and the Comparative Method'. American Political Science Review 65.3: 682-693.

Luders, Joseph. 2010. The Civil Rights Movement and the Logic of Social Change. New York: Cambridge University Press.

Jasper, James. 2004. 'A Strategic Approach to Collective Action: Looking for Agency in Social-Movement Choices'. Mobilization 9.1:1-16.

Jasper, James. 2007. Getting Your Way: Strategic Dilemmas in the Real World. Chicago: University of Chicago Press.

Jasper, James, and Jan Willem Duyvendak, eds. 2015. Players and Arenas: The Interactive Dynamics of Protest. Amsterdam: Amsterdam University Press.

Khawaja, Marwan. 1995. 'The Dynamics of Local Collective Action in the West Bank: A Test of Rival Explanations'. Economic Development and Cultural Change 44.1: 147-179.

Maguire, Diarmuid. 1993. 'Protesters, Counterprotesters, and the Authorities' Annals of the AAPSS 528:101-113.

Maney, Gregory M. 2000. 'Transnational Mobilization and Civil Rights in Northern Ireland'. Social Problems 47.2: 153-179.

Maney, Gregory M. 2007. 'From Civil War to Civil Rights and Back Again: The Interrelation of Rebellion and Protest in Northern Ireland, 1955-1972'. In Research in Social Movements, Conflicts and Change, Volume 27, ed. Patrick G. Coy. Bingley: Emerald, 3-35.

Maney, Gregory M. 2012a. 'Agreeing for Different Reasons: Ideology, Strategic Differences, and Coalition Dynamics in the Northern Ireland Civil Rights Movement'. In Strategy in Action: Movements and Social Change, ed. G.M. Maney, R. Kutz-Flamenbaum, D. Rohlinger, and J. Goodwin. Minneapolis: University of Minnesota Press.

Maney, Gregory M. 2012b. 'The Paradox of Reform: The Civil Rights Movement in Northern Ireland'. In Research in Social Movements, Conflicts and Change, Vol. 34, ed. Sharon Erickson Nepstad and Lester R. Kurtz. Bingley: Emerald, 3-26. 
Maney, Gregory M., Michael A. McCarthy, and Grace B. Yukich. 2012. 'Explaining Political Violence against Civilians in Northern Ireland: A Contention-Oriented Approach'. Mobilization 17.1: 27-48.

Martheu, Elisabeth, ed. 2009. Civil Rights Organizations and Protest Movements in Israel: Mobilization around the Israeli-Palestinian Conflict. London: Palgrave.

McAdam, Doug, Sidney Tarrow, and Charles Tilly. 2001. Dynamics of Contention. Cambridge: Cambridge University Press.

McGarry, John, and Brendan O'Leary. 1995. Explaining Northern Ireland: Broken Images. London: Wiley.

Melucci, Alberto, and Mario Diani. 1992. Nazioni Senza Stato: i Movimenti Etnico Nazionali in Occidente. Milano: Feltrinelli.

Muro, Diego. 2015. 'Ethnicity, Nationalism, and Social Movements'. In The Oxford Handbook of Social Movements, ed. Donatella della Porta and Mario Diani. Oxford: Oxford University Press, 185-199.

Nagle, John. 2008. 'Challenging Ethno-National Division: New Social Movements in Belfast'. Social Movement Studies 7.3: 305-318.

Nagle, John. 2015. “Sectarianism: Danger”: Nonsectarian Social Movements and Identity Politics in Divided Societies'. In The Identity Dilemma: SocialMovements and Collective Identity, ed. A. McGarry and James Jasper. Philadelphia: Temple University Press, 45-64.

Nordlinger, Eric A. 1972. Conflict Regulation in Divided Societies. Cambridge, MA: Harvard University Press.

Norwich, Llora. 2015. 'Fighting by the Rules: A Comparative Framework for Exploring Ethnic Mobilization Patterns in Democratic Contexts', Ethnopolitics 14.4: 354-381.

Ó Dochartaigh, Niall. 2005. From Civil Rights to Armalites: Derry and the Birth of the Irish Troubles. Basingstoke: Palgrave Macmillan.

Ó Dochartaigh, Niall. 2016. 'Northern Ireland since 1920'. In The Princeton History of Modern Ireland, ed. Richard Bourke and Ian McBride. Princeton: Princeton University Press, 141-167.

Ó Dochartaigh, Niall, and Lorenzo Bosi. 2010. 'Territoriality and Mobilization: The Civil Rights Campaign in Northern Ireland'. Mobilization 15.4: 405-424.

O'Hearn, Denis. 2009. 'Repression and Solidary Cultures of Resistance: Irish Political Prisoners on Protest'. American Journal of Sociology 115.2: 491-526.

Olzak, Susan, and Johan L. Olivier. 1998. 'Racial Conflict and Protest in South Africa and the United States'. European Sociological Review 14.3: 255-278.

Purdie, Bob. 1990. Politics in the Streets: The Origins of the Civil Rights Movement in Northern Ireland. Belfast: Blackstaff Press.

Rose, Richard. 1971. Governing without Consensus: An Irish Perspective. Boston: Beacon Press. 
Ruane, Joseph. 2017. 'Modelling Ireland's Crises: North, South, and North-South Intersections'. In Dynamics of Political Change in Ireland: Making and Breaking a Divided Island, ed. Niall Ó Dochartaigh, Katy Hayward, and Elizabeth Meehan. London: Routledge (forthcoming).

Ruane, Joseph, and Jennifer Todd. 1996. The Dynamics of Conflict in Northern Ireland:Power, Conflict and Emancipation. Cambridge: Cambridge University Press.

Ruane, Joseph, and Jennifer Todd. 2004. 'The Roots of Intense Ethnic Conflict May Not in Fact Be Ethnic: Categories, Communities and Path Dependence'. European Journal of Sociology 45.2: 209-232.

Seidman, Gay W. 2000. 'Blurred Lines: Nonviolence in South Africa'. PS: Political Science \& Politics 33.2: 161-168.

Seidman, Gay W. 2011. 'Guerrillas in their Midst: Armed Struggle in the South African Anti-apartheid Movement'. Mobilization 6.2: 111-127.

Smithey, Lee A. 2009. 'Conflict Transformation, Cultural Innovation, and Loyalist Identity in Northern Ireland'. In Culture and Belonging in Divided Societies: Contestation and Symbolic Landscapes, ed. M. Ross. Philadelphia: University of Pennsylvania Press, 85-106.

Smithey, Lee A. 2011. Unionists, Loyalists, and Conflict Transformation in Northern Ireland. Oxford: Oxford University Press.

Smithey, Lee A., and Michael P. Young. 2010. 'Parading Protest: Orange Parades in Northern Ireland and Temperance Parades in Antebellum America'. Social Movement Studies 9.4: 393-410.

Snow, David, Sarah Soule, and Hanspeter Kriesi, eds. 2004. The Blackwell Companion to Social Movements. John Wiley \& Sons.

Tilly, Charles. 1978. From Mobilization to Revolution. Reading: Addison.

Tilly, Charles. 2003. The Politics of Collective Violence. Cambridge: Cambridge University Press.

Tilly, Charles. 2004. 'Social Boundary Mechanisms'. Philosophy of the Social Sciences 34.2: $211-236$.

Tilly, Charles. 2008. Contentious Performances. Cambridge: Cambridge University Press.

Tilly, Charles, and Sidney Tarrow. 2007. Contentious Politics. Oxford: Oxford University Press.

Touquet, Heleen. 2015. 'Non-ethnic Mobilisation in Deeply Divided Societies: The Case of the Sarajevo Protests'. Europe-Asia Studies 67-3: 388-408.

Vladisavljevic, Nebojsa. 2002. 'Nationalism, Social Movement Theory and Grass Roots Movement of Kosovo Serbs, 1985-1988'. Europe-Asia Studies 45.5: 771-790.

Watts, Nicole F. 2006. 'Activists in Office: Pro-Kurdish Contentious Politics in Turkey. Ethnopolitics 5.2:125-144. 
White, Robert W. 1989. 'From Peaceful Protest to Guerrilla War: Micro-mobilization of the Provisional Irish Republican Army'. American Journal of Sociology 94.6: 1277-1302.

White, Robert W. 1992. 'Political Violence by the Non-aggrieved: Explaining the Political Participation of Those with No Apparent Grievances'. In International Social Movement Research: Participation in Clandestine Political Organizations, ed. Donatella della Porta. Greenwich, CT: JAI Press, 79-103.

White, Robert W. 1993. Provisional Irish Republicans: An Oral and Interpretive History. Westport, CT: Greenwood Press.

White, Robert W. 1999. 'Comparing State Repression of Pro-state Vigilantes and Anti-state Insurgents: Northern Ireland, 1972-75' Mobilization 4.2: 189-202.

White, Robert W. 2007. "I'm Not Too Sure What I Told You the Last Time”: A Methodological Note on the Consistency of the Accounts of Activists in Political Violence'. Mobilization 12: 287-306.

White, Robert W. 2010. 'Structural Identity Theory and the Post-Recruitment Activism of Irish Republicans: Persistence, Disengagement, Splits, and Dissidents in Social Movement Organizations'. Social Problems 57-3: 341-370.

Wimmer, Andreas. 2013. Waves of War: Nationalism, State Formation, and Ethnic Exclusion in the Modern World. Cambridge: Cambridge University Press, 2012. Yiftachel, Oren, and As'ad Ghanem. 2004. 'Understanding “Ethnocratic” Regimes: The Politics of Seizing Contested Territories'. Political Geography 23.6:647-676. 


\title{
2 What Did the Civil Rights Movement Want?
}

Changing Goals and Underlying Continuities in the Transition from Protest to Violence

\author{
Niall Ó Dochartaigh
}

\section{Introduction}

Early social movement research tended to draw a sharp distinction between peaceful protest and armed conflict. One consequence of this was that social movement researchers tended to focus on stable democratic societies rather than divided societies where political violence was an important part of the repertoire of contention. This sharp distinction between protest and political violence has been strongly challenged over the past two decades by research that locates both forms of contention within a broader continuum of contentious politics and explores the strong links and continuities between them. Della Porta's groundbreaking work on the transition from protest to violence in 1970s Germany and Italy (1995) was one of the first studies to show just how intimately they were interrelated. Robert White's work on the Provisional Irish Republican Army (IRA) (1989) was one of the earliest social movement analyses of these links in the Irish context. The development of the contentious politics frame (see, for example, McAdam, Tarrow, and Tilly 2001; Tilly 2003; Tilly and Tarrow 2007) has reinforced this understanding. As Tilly (2003: 238) puts it:

$[C]$ ollective violence [...] emerges from the ebb and flow of collective claim making and struggles for power. It interweaves incessantly with nonviolent politics $[. .$.$] and changes as a consequence of essentially the$ same causes that operate in the nonviolent zones of collective political life.

A growing body of work in recent years demonstrates the very close links between protest and subsequent outbreaks of violence, the persistence of peaceful protest tactics alongside the use of violence, and the important continuities in terms of social relations and political dynamics (for a review, see Bosi and Malthaner 2015). 
Despite this, the literature continues to see a sharp distinction between protests and political violence in certain respects. Political violence seems to be accompanied by radically different aims and goals. Protests seeking reform and amelioration of grievances within existing structures give way to violent groups with strong ideologies and demands for dramatic territorial and constitutional change. This argument has frequently been made in analyses of the shift from civil rights protest to republican armed struggle in Northern Ireland after 1969. Modest demands for reform in housing allocation, the franchise and employment discrimination were replaced by the aim of reunifying Ireland and expelling the British state from Northern Ireland. Armed organizations might have emerged from a context of peaceful protest but their goals seemed to indicate a sharp break rather than continuity with the goals of protestors.

This chapter re-examines and reassesses the aims and goals of the civil rights movement and finds surprising continuities in goals between these two different phases of contention. It argues that these continuities are directly related to the distinctive political dynamics at work in divided societies where differential access to state power and institutions is at the heart of political disagreement and conflict.

The chapter begins by outlining contemporary debates on the character, sincerity, and material basis of the movement's goals and aims and the way in which those debates were linked to wider struggles over the allocation of political responsibility for the turn to violence. These debates shaped the first wave of academic analysis of the civil rights movement's goals. The chapter outlines how this first wave of scholarship on movement aims has been augmented in recent years by a large body of new work within the social movement tradition. This more recent work emphasizes political process and the dynamic and contested character of movement goals. The chapter then examines the importance of two major continuities in the goals of the movement, relating to repression and to the institutionalization of the power of the minority. It examines the extent to which these goals were present before mass mobilization and continued to be central to the programmes of armed republican organizations after the outbreak of violence. It explains the failure of reform and the transition to violence as the result, in part, of the failure of the movement to achieve these underlying goals. Finally, it looks at the way in which Provisional IRA negotiating positions during the conflict show surprisingly strong continuity with key underlying aims of the civil rights movement.

The chapter is based on extensive empirical research by the author over the course of more than two decades, including interviews with civil 
rights activists, former IRA members, unionist and nationalist politicians and intermediaries; newspaper coverage in local newspapers; the private papers of republican leaders and intermediaries; and a wide range of ephemeral primary sources. This includes an exhaustive study of coverage of the civil rights campaign and the escalation of violence (1968-1972) in two local newspapers in Derry, the capital city of the civil rights campaign. These two local newspapers, the Derry Journal and the Londonderry Sentinel, catered to nationalist and unionist audiences respectively and act as an important check on each other. Primary sources that inform the chapter also include documentation on the IRA's goals and negotiating positions over the course of the conflict drawn from private papers and state archives. Sources are described in more detail in Ó Dochartaigh (1999, 2005, 2011, 2015).

\section{Debating the Goals of the Movement}

As the civil rights movement reached the peak of its influence in late 1968 questions about its goals were posed with increasing urgency. What would satisfy the protestors? What would bring an end to the agitation and restore order and stability? The argument that the movement had secured its goals and that the primary responsibility of its leadership was to secure demobilization and work to stabilize a reformed Northern Ireland emerged at a very early stage. After the first reforms in November 1968, for example, the liberal Church of Ireland Bishop of Derry Charles Tyndall was 'quite happy [that] everything seems to have come to a peaceful conclusion' and 'hoped it would stay that way' (Derry Journal 1968). When protests continued into 1969 , and were increasingly associated with violent rioting, liberal unionists argued that the demands of the movement had now been met and that there remained no legitimate cause for complaint. After the deployment of British troops and the direct involvement of the British government in August 1969 a more far-reaching reform programme was introduced. When the IRA subsequently re-emerged as a major force, the British government moved closer to the unionist position that the goals of the civil rights movement had been met.

The liberal unionist and British government argument that the goals of the movement were limited and reformist, seeking only to remedy egregious abuses, found a strange echo at the other end of the political spectrum. Republicans who subsequently launched an armed campaign to end British rule also argued that protestors had only been looking for their 
rights', seeking an end to discrimination and exclusion. The repression of the civil rights movement and resistance to its limited demands were used by republicans as evidence that peaceful protest was not effective and to justify the IRA campaign. As Gerry Adams puts it: 'The civil rights movement had been looking for democratisation of the state, but the state had made abundantly clear the fact that it would not and could not implement democratic reforms' (Adams 1986: 34). According to this version the protestors were seeking only universal rights but were beaten off the streets. The reforms that did come were too little too late. When the British Army was deployed it became implicated in this repression, upholding the power of a sectarian state. Where liberal unionists and British ministers characterized repression as regrettable and responsive, republicans focused on repression as the arena in which civil liberties were flouted most egregiously and flagrantly. The anti-internment marches by the Northern Ireland Civil Rights Association (NICRA) in late 1971 and early 1972 are seen from this perspective as fully continuous with the early civil rights mobilization. And the killing of thirteen civilians by British soldiers at the NICRA march on Bloody Sunday in 1972 is seen as the apotheosis of the state's repressive response to mass civil rights mobilization.

Liberal unionists and the British government disagreed with republicans on the relationship between the civil rights agenda and the subsequent violence but they shared the same view of the movement's initial goals and aims. A quite different view of these aims was expressed in the contemporary loyalist placards proclaiming 'IRA = CRA'. Unionist right-wingers argued that civil rights was a front for the IRA and viewed the movement as dishonest and deceitful. As one prominent unionist put it: '[T] he civil rights movement was seen as a Trojan horse or stalking horse for Republicanism' (Clifford Smyth, quoted in Maney 2007: 22).

They argued that the movement's true goals, to weaken the Unionist government, destroy Northern Ireland, and reunify Ireland, were deliberately concealed. The fact that violence escalated despite reform was confirmation of this insincerity.

This view finds a strange echo at the far end of the spectrum, from left-wing radicals such as Eamonn McCann who emphasized far-reaching goals of social transformation and deliberately sought to provoke a repressive state reaction in order to radicalize people (McCann 1993). These contrasting contemporary analyses of the movement's goals, as limited and reformist or covertly radical, set the terms for subsequent academic debate. 


\section{From Conspiracy Theory to Political Process Theory}

Scholarly debate on the goals of the movement moved through two distinct phases. The first phase began with Paul Arthur's 1974 study The People's Democracy and was subsequently dominated by John Whyte's key article on discrimination (1983) and exchanges between Hewitt (1981, 1983), O'Hearn (1983), and Kovalcheck (1987) in the British Journal of Sociology. Debates centred on the sincerity and the substance of the movement's declared aims. Hewitt argued that demands for reform masked a nationalist agenda:

Since many nationalists believed that a separate 'Six County' state could not survive if Catholics 'got their rights' we can explain why they joined the civil rights movement. They were not implicitly accepting partition by demanding civil rights but instead confident that this was the strategy which would end partition. (Hewitt 1981: 374)

Hewitt argued too that the grievances the movement articulated were unfounded or grossly exaggerated: 'one must abandon the position that Catholics were severely discriminated against in Northern Ireland' (1981: 368). O'Hearn's reply focused accordingly on the question of whether discrimination did indeed take place, an issue addressed too in Whyte's (1983) 'How Much Discrimination Was There under the Unionist Regime?' Whyte concluded in his firmly understated way that serious discrimination had indeed taken place, but that it was concentrated in Unionist-controlled local authority areas west of the Bann.

The second element in this debate - the sincerity of the movement's stated aims - was first addressed forensically in Bob Purdie's 1988 article 'Was the Civil Rights Campaign a Republican/Communist Conspiracy?' The question of the 'real' goals of the movement and their relationship to the subsequent IRA campaign were dealt with at greater length in his Politics in the Streets (1990). Purdie was the first to systematically and convincingly demonstrate the extent of republican involvement. More recently, Maney's analysis of more than 200 civil rights events has established that republicans were involved in organizing almost 80 per cent of them (2007: 20). These findings are unsettling for those who seek to put clear blue water between the civil rights movement and the IRA. Purdie also found, however, that republicans did not see the movement as a means to prepare the ground for an armed campaign by the IRA (1990: 129-130). In fact, for many of the Marxist republican enthusiasts for civil rights it was conceived as part of a broader shift away from militarism and towards broad-based political 
activism, even if they still aimed for the reunification of Ireland in the long-term.

Although radical forces were involved and never abandoned their longterm aims, their immediate ambitions for the movement were quite limited and reformist. Brian Hanley has recently brought to light an important new source of information on IRA thinking during this period, a report of a meeting in County Tipperary in August 1967 of 25 IRA officers, 'including almost all the IRA's leading figures' (Hanley 2013). One of them, Liam McMillen, was actually a member of the NICRA executive but the civil rights campaign was not even discussed at the meeting. There is little sense in these minutes that the IRA leaders regarded the civil rights movement as a particularly promising or important initiative or that they felt they were on the verge of a major political transformation. And there is no indication that the civil rights association formed any significant part of their military thinking.

This first phase in the academic debate concluded therefore that there was at least some substance to the grievances and goals of the movement. It demonstrated that republicans were more deeply involved than was acknowledged at the time but this did not mean that their support for the reformist goals of the movement was insincere or that reform was not significant and important to them in its own right. In confirming the extent of republican involvement in the movement, it did, however, undermine the argument that these two phases of contention - civil rights and the IRA campaign - were separate and distinct phenomena.

The last ten to fifteen years has seen a second wave of scholarship on the civil rights movement (Bosi 2006, 2007, 2008, 2016; De Fazio 2007; Hancock 2014; Maney 2000, 2007, 2012a, 2012b; Ó Dochartaigh 1999, 2005; Ó Dochartaigh and Bosi 2010; Prince 2007; Prince and Warner 2012). Much of this work focuses on key debates in the social movement literature, analysing the dynamics of mobilization, the diffusion of repertoires of contention, and looking at the relationship between protest and political violence. It includes comparative work on the US Civil Rights Movement which provides a kind of academic echo of the political comparisons made at the time (Dooley 1998; De Fazio 2009).

This work is characterized by a focus on process and on the dynamic and shifting character of the movement. It demonstrates that there were shifts in the composition of the leadership and in grass-roots support but there were shifts too in the movement's demands and goals. Bosi (2006:83), for example, argues that a shift in structural conditions after the Second World War 'created conditions in which the CRM's initial reformist message (1960-1968) was able to resonate with selected segments of Northern Irish society' but 
that 'sectarian cleavages in Northern Ireland reasserted themselves, and this led to the privileging of an antisystem master frame' by 1968. Maney, similarly references political process theory and emphasizes the changing political opportunity structure, arguing that: 'trajectories of contention alter the stated objectives and forms of collective action of insurgents' (2007:5).

This work stresses that the civil rights movement was a site of struggle between political actors with competing agendas. The formal goals of the movement reflected a compromise between competing political forces, a product of complexity and struggle rather than conspiracy or insincerity. Bosi puts it clearly:

[I]deologically diverse groups of activists began to forge new ties and relationships that spanned several groups in order to 'symbolically produce' a reformist mobilizing message of civil rights, social justice, and progressive politics, rather than getting mired in time-worn discussions about partition. (2006: 86)

In these circumstances we would not expect the stated goals to reflect the full extent of the political aims of those involved in the movement. They were a lowest common denominator around which all could unite. From this perspective, violence emerged as part of an unpredictably unfolding process in which expectations, demands, goals and political priorities all changed in response to circumstances. As violence and confrontation with the RUC and loyalists escalated through 1969, the movement's supporters and leaders focused increasingly on the issue of repression and Unionist political control. As Bosi puts it:

Mobilizing messages [...] are social constructions reflecting complex interactions between significant actors in the political system. They do not simply exist a priori in a condition of stasis but they change repeatedly, generating identity shifts, collective redefinitions of opportunities, new alliance structures, strategy changes, and goal transformations. (2006: 83)

Bosi et al. (2014) identify movement-state interaction as one of the four processes that are crucial in radicalization and the transition from protest to political violence. It was direct confrontation with the unionist government and with state forces on the streets that brought the issues of repression and unionist political control to the fore.

This process was further intensified by loyalist counterdemonstrations which greatly increased the opportunities for violent confrontation. On 
several occasions the security forces were seen to facilitate loyalist violence or even to work in tandem with loyalist civilians, at Burntollet in January 1969 and in Derry in August 1969, for example. De Fazio, who emphasizes the importance of interaction with counter-movement activists in radicalization, argues that these confrontations 'prompted an object shift among activists, as loyalist violence on civil rights demonstrations helped to displace the initial reformist agenda of the CRM' (2013: 484; emphasis in original).

The focus on repression and political control rather than discrimination and voting rights was the direct outcome of interaction with the state during the process of mobilization. But although these issues took on a new urgency and prominence during the campaign, they were not entirely new issues and the continuities here are just as important as the changes. The following sections trace the continuities in the aims of the civil rights movement as they related to those two key issues of state repression and the exclusion of the minority from political power.

\section{Challenging Repression}

At the peak of its influence the civil right movement was identified with two main goals: reform of the franchise ('one man one vote') and an end to discrimination in housing and employment. The NICRA constitution of 1967 makes no explicit mention of either voting rights or discrimination, however. Its five objectives were stated in rather general terms:

(1) To defend the basic freedoms of all citizens. (2) To protect the rights of the individual. (3) To highlight all possible abuses of power. (4) To demand guarantees for freedom of speech, assembly and association. (5) To inform the public of their lawful rights. (Purdie 1990:133)

We might reasonably argue that discrimination and the franchise were implicit in NICRA's aims of 'highlighting all possible abuses of power' and 'protecting the rights of individuals' but it is striking nonetheless that the word 'discrimination' is not used once. One demand is, however, spelled out in quite specific terms - for 'freedom of speech, assembly and association'. While there is a tendency sometimes to pass quickly over this, it indicates that repression and state restrictions on protest were a central issue even before the marching campaign began.

The Unionist government enjoyed extensive repressive powers under the Special Powers Act, including internment and the power to ban assemblies, 
marches, publications, and parties. These powers had a freezing effect that was combined with occasional violent repression to control and restrict oppositional protest. Successful state repression of nationalist and republican demonstrations and protests in the 1950s and 196os closed down the space for the opposition to exert pressure outside the formal parliamentary system. When the Nationalist Party tried to march in Derry city centre in 1952, for example, the march was banned and then broken up violently by an RUC baton charge (Derry Journal 1952). One consequence of such demonstrations of police force was a great reluctance to defy these bans. The next march to defy a ban in Derry was the civil rights march of October 1968 whose violent dispersal marked the beginning of the conflict.

Republican parades took place at Easter every year throughout the 1950s and 1960 s but were banned from urban centres and often hedged about by restrictions on the display of symbols and on the routes they could follow. Sometimes they were banned outright, as in 1967 when Stormont banned the centenary commemorations of the Fenian Rising of 1867 (Purdie 1990: 134). The official history of NICRA states that the association began to realise in early 1968 'that a ban on demonstrations was an effective government weapon against political protest' and that marches would provide a more effective way of exerting political pressure than letter-writing (Purdie 1990: 135). The importance attached to challenging restrictions on protest was emphasized in spring 1968, a few months before NICRA organized its first march. In April 1968, republicans successfully defied a Unionist government ban on the annual Easter parade in Armagh. At around the same time republicans pressed for NICRA to begin a campaign of protest marches (Hanley 2013). The marching campaign was aimed in part at pushing back against state limitations on protest and asserting the right to protest. The banning of marches and the defiance of such bans were not therefore incidental to the campaign for civil rights. Challenging the restrictions on protest and clearing the political space for the use of mass mobilization to exert political pressure was one of the key goals of many of those within the civil rights movement. It was explicitly stated in that NICRA aim of 'freedom of speech, assembly and association'.

From the moment that the RUC baton-charged the march in Derry in October 1968 repression of protest became the central mobilizing issue (Ó Dochartaigh 2005: 291-292). Grievances surrounding discrimination and the franchise had mobilized very small numbers of activists in the previous years. The baton charge, however, immediately sparked offlarge-scale street rioting in the Bogside and spurred thousands of people to turn up at public meetings and join subsequent protests. The issue of repression, of how the 
state treated oppositional forces associated with the minority community, generated mass mobilization in a way that no other issue could. It generated 'moral outrage' (Wood 2003) in a much more immediate and visceral way than the obscure workings of the franchise and housing discrimination.

By 1969, a grudging start had been made in addressing the franchise and housing discrimination, but the problem of state repression had been exacerbated immeasurably. The breakdown of order, the failure of police reform, and the militarization of policing in nationalist areas preceded the IRA campaign and the failure to resolve these issues opened up the political space for that campaign.

Now that repression had been placed at the heart of the political debate and its effectiveness eroded through mass mobilization by the minority population, how was order to be maintained? Those who argued that demands had been met and that protest should be ended provided one answer - renewed quiescence. This brings us to the second of those continuities in the goals of the movement.

\section{Institutionalizing Oppositional Power}

The argument that the civil rights movement aspired to relatively minor adjustments to Unionist rule obscures one of its most important goals. The various wings of the civil rights movement had different visions of the future, different strategic priorities, and different ideological preferences but for all of them a central element in that vision of transformation was the ending of the Unionist Party's 50-year monopoly of political power in Northern Ireland. Ending that domination, rather than simply presenting a fleeting challenge to it, would require some kind of institutionalization of oppositional power.

The civil rights movement stretched well beyond nationalists and republicans. Northern Ireland Labour Party and Liberal Party activists played a prominent role along with Marxists of several different varieties, from both Catholic and Protestant backgrounds. It was not a nationalist movement but it was nonetheless a movement that challenged unionist domination and the unionist monopoly on political power. This was one of the main reasons why even liberal unionists steered clear of it. There was a Young Unionist Party member on the first NICRA executive but not on any subsequent executive, and there were no Unionist Party members in the Derry activist groups or the Campaign for Social Justice. Protestant activists in the movement such as Ivan Cooper of the Labour Party or Claude 
Wilton of the Liberals belonged to a broader unionist cultural community but they were anti-unionist in the sense that the Unionist Party was their primary political opponent. Although the different wings of the movement envisaged different paths by which the Unionist Party's monopoly on power might be broken, this aim nonetheless provided a unifying focus for almost all of those involved.

One possible route was through the building of an anti-unionist electoral coalition. This was precisely the role that some Marxist republicans saw for the civil rights movement and social agitation in general. Protestants would unite with Catholics on social issues and eventually form an antiUnionist majority in parliament. Unionist domination would be ended and oppositional power institutionalized through the electoral system. This was not a narrow nationalist vision but a vision of Catholic and Protestant unity based on a shared goal of social transformation. The ending of Unionist Party domination was nonetheless at its centre.

The alliance of republicans and left-wing activists in Derry from the early 1960 focused on a variety of social issues and their agenda looked quite different to that of NICRA. They invoked the rhetoric of civil rights as early as 1963 and 1964 but their primary concerns were poor housing and high unemployment and they were driven by much broader goals of social transformation.

These activists asserted their independence from communal loyalties by stressing that they opposed both 'Green' and 'Orange' Tories, both the Nationalist Party and the Unionists. But the 'Green Tories' were a permanently marginalized, ineffectual, and demoralized opposition party with no power whatsoever. Ending 'Tory' power meant above all ending Unionist Party domination of government and politics. While Labour Marxists and republican Marxists differed in their views on the relative importance and significance of Irish reunification in this process, neither faction was seeking simply to end the most egregious abuses of the system. They sought a much broader social transformation, central to which was the ending of the frozen politics of the North and the domination of the Unionist Party.

As violence escalated the various forces that had united in the civil rights movement began to reformulate their goals. After British troops were deployed in August 1969, local defence committees demanded the abolition of the Stormont parliament as a condition for the removal of the barricades. By the early 1970 s both the SDLP and Provisional republicans were demanding an end to unionist domination through the transformation of structures of government. The SDLP worked towards power-sharing arrangements that would guarantee the representation of the Catholic 
minority in the North's government along with all-Ireland structures that would give a role to the Irish government. Provisional republicans also sought the abolition of the Unionist-controlled parliament at Stormont. They wanted to institutionalize oppositional power and the position of the nationalist minority through a reunification of Ireland that would make Northern Catholics once again part of an all-Ireland nationalist majority. From the perspective of many unionists this shift from a demand for the ending of discrimination to demands for institutional transformation was evidence that the movement had concealed its true goals. These shifts took place in response to rapidly changing and dramatic events. But they also reflect deep underlying continuities. From the beginning forces within the civil rights movement sought to bring an end to Unionist one-party domination.

\section{The Failure of Institutionalization}

The first reform programme was announced by the Unionist government in November 1968 under intense pressure from the British Prime Minister, Harold Wilson. Key reforms included the abolition of Derry Corporation, the end of restrictions on the franchise for elections to Stormont, and the introduction of a points system for housing (see Turner and De Fazio, in this volume).

One major problem with these changes was that the Unionist Party remained securely in control of government with only one significant threat to its parliamentary majority - the threat from the unionist right. This dynamic ensured that reforms were minimized for fear of losing right-wing unionist support. For example, the reforms included a points system for allocating public housing but left it up to local authorities to devise their own systems. Most importantly, this package did not end the restricted franchise in local government and included no measures that would actually guarantee the end of unionist control of districts where nationalists were a majority, except for Derry where a development commission was to take charge. The second difficulty was reversibility. All of the important levers of power remained in the hands of the Unionist Party. When local government was re-organized, when new ward boundaries were drawn, when decisions were made on how much power local authorities would have, Stormont would decide. If opposition parties won control of more local authorities the Unionist Party could ensure that important powers were moved to Stormont where oppositional forces were a permanent minority. 
This would be difficult if there was intense scrutiny and direct pressure from the British government of the kind that was applied during the civil rights campaign. But this was a big if. The British government had breached the convention that Westminster should not interfere but this change was not put on any firm institutional footing. British involvement would only be assured if there was continuing disorder and pressure from oppositional forces in the North.

McAdam points out that the key problem facing actors outside the political system 'is to devise some way to overcome the basic powerlessness' of their position. Mass mobilization can do this but it is very difficult to sustain over the long term and for a movement to survive 'it must either parlay its initial successes into positions of institutionalized power [...] or continue to experiment with non-institutional forms of protest' (McAdam 1983: 735). If the campaign subsided now before there were major changes to the system of government it could prove extremely difficult to get the British government to intervene in a similarly decisive way in the future. And if sections of the movement were co-opted through a limited institutionalization of their power that left existing power structures intact it could split the movement and remove the more moderate voices.

The most important way in which the power of the civil rights movement was institutionalized was through the setting up of the Social Democratic and Labour Party (SDLP) in 1970. It was set up by civil rights leaders such as John Hume and Ivan Cooper who had been elected to the Stormont parliament in 1969 along with other MPs who had supported the movement. But the limits of parliamentary power were illustrated at a very early stage. In spring 1969 Hume and Cooper announced that they no longer supported street protest due to the increasing likelihood of violence. Instead, they would move their activism into the parliamentary arena. Their first major stand in parliament was to oppose the Unionist government's new public order bill which outlawed a range of protest tactics, including sit-downs. But the unionist government had the same secure majority that it had enjoyed for the previous half century and the bill passed. The failure of parliamentary opposition in this case indicated that without a transformation of political structures, or ongoing pressure on the streets, unionist power could be restored and reinforced. It made clear the limits of British willingness to intervene on behalf of the nationalist minority. The power of the moderates within the civil rights movement had been institutionalized in parliament. But because this process was not accompanied by institutional change it served mainly to highlight the limits of this form of institutionalization. This form of co-optation separated moderates from more radical sections 
of the movement rather than providing the basis for the co-optation of the movement as a whole (Bosi 2016).

The subsequent escalation was a consequence in part of what Maney (2012b) has called the 'paradox of reform' whereby reforms that are slowly and reluctantly conceded serve to demobilize moderate elements within a protest movement. But because reforms are limited, potentially reversible, slowly implemented, and accompanied by a violent counter-movement backlash, those who remain active are more likely to be convinced of the value of armed action. Turner and De Fazio (in this volume) further illuminate this dialectic between reform, counter-movement violence, and escalation. They describe how the Unionist government attempted 'to navigate high disruption and concession costs by alternating limited concessions and repression [...] a rational response to a very vulnerable political situation'.

This first wave of reforms did nothing to address the issue of repression and in fact intensified the restrictions on protest. The next major wave of reforms would address this issue directly, however. In August 1969 the Unionist government requested the deployment of British troops on the streets to restore order because their own coercive capacity had been exhausted. The price of assistance was a major reform package, including reform of policing. It also saw a strengthening of the British government's role in Northern Ireland with the appointment of a UK representative to liaise with the Unionist government. This was reinforced by the appointment of senior British officials to oversee police reform and of an English policeman, Sir Arthur Young, as Chief Constable of the RUC. The UK representative Oliver Wright now began to consult regularly with Cardinal Conway, the Armaghbased Primate of All Ireland, thus opening up a channel of communication with elements of the Catholic minority (Patterson 2008).

In the face of unionist and loyalist resistance, however, the British government retreated from its ambitious programme of change, allowing Stormont to reverse the effect of some of the most important reforms (Ó Dochartaigh 2016; Maney 2007: 17-18). The impact of the single most important reform - the disarming of the RUC - was entirely nullified by the intensified militarization of policing through deployment of the British Army in nationalist areas. Minority political influence remained very weak after these reforms, even as repression, the primary mobilizing issue of the civil rights movement, became an ever more urgent issue. The Sunningdale power-sharing initiative in 1973-1974 failed due to unionist and loyalist opposition and continued IRA violence and it would take almost 30 years before a system that gave institutionalized political power to the Catholic minority was established on a firm footing (Bosi 2016: 354-355). 


\section{The Civil Rights Movement and the Goals of the IRA}

On the face of it, the Provisional IRA, which escalated its violence from 1970 onwards, had completely different aims to the civil rights movement, seeking to expel the British state by force and reunite Ireland as an independent republic. But while these ultimate aims served to keep the movement united and to motivate armed activists, the negotiating positions the republican leadership adopted during the conflict show very strong continuities with the underlying concerns that had driven the civil rights mobilization. One striking illustration of this is the front page of An Phoblacht, the weekly newspaper of the movement, on 24 December 1972. At the height of the IRA's violence, the paper chose to blazon across its front page four preconditions for the end of the IRA campaign:

WE DEMAND

Abolition of Repressive Legislation

British Troops be Withdrawn

Release of All Political Prisoners

Full Support for Civil Rights

Then - and only then - will we have a true and lasting peace in Ireland.

(An Phoblacht1972)

There is no mention here of Irish unification, of self-determination, or of core republican ideological positions. It does not mean that the movement had abandoned its goals of Irish unity and sovereignty. The republican leadership was seeking to provide space for a negotiated settlement with the British government in which they would have to compromise on ideological goals. But it is striking that in formulating their negotiating position they stripped it back to a set of issues that resonated very strongly with the original concerns of the civil rights movement and its focus on state repression. None of the demands directly involved Irish self-determination. These limited bargaining positions co-existed with strongly ideological and uncompromising rhetoric that suggested that the movement did indeed have completely different aims to those that underlay the civil rights mobilization. But this strong rhetoric had multiple functions. It was used to keep the movement united and ideologically coherent, to sustain morale and support, and to strengthen its bargaining position with the British state by presenting the movement as strong and confident. In a situation of violent conflict where people are risking their lives to pursue political goals, an ambitious transformative political programme is important in 
motivating activists. But the fact that the IRA's bargaining position was so dominated by key issues that motivated the civil rights mobilization show that the highly ideological rhetoric of the IRA obscured deep continuities in goals and aims with the civil rights mobilization that preceded it.

\section{Conclusion}

The debate on the goals of the civil rights movement is connected to much broader questions in the social movement literature about the relationship between peaceful protest and political violence in cycles of contention. For many who seek to assert the peacefulness and legitimacy of the civil rights movement it has been important to draw a sharp distinction between these two phases. The way in which the goals of the civil rights movement developed and changed as confrontation intensified demonstrates, however, just how tightly and intimately linked these two phases were, as does the negotiating position the IRA adopted during its armed campaign.

It is widely agreed now in the social movement literature that protest and political violence can usefully be analysed as part of a continuum of contention. In understanding the transition from one phase to the next the discussion of movement aims and goals tends to focus primarily on change. Demands for reform are displaced by calls for revolutionary transformation. Interaction with the state, and with counter-movement forces as well as intraparty competition are important in understanding why new demands emerge and radicalization is defined in part by that transformation of goals and aims.

But given that the concept of continuum emphasizes the links between these different phases, a more systematic exploration of the continuities in goals and aims that run through these different phases of contention might enrich our understanding of this process of change. In the course of the civil rights campaign in Northern Ireland demands relating to discrimination and the restricted suffrage were superseded by the issues of repression and unionist political control. But these latter two issues had provided the deep underlying motivation for many of the movement's founders, before the dramatic confrontations that brought them to the centre of debate. These two issues were to the fore as well in the bargaining positions the IRA leadership adopted in the early 1970s when it engaged directly with the British state.

As well as identifying the importance of these issues in the initial emergence of the civil rights movement we can also trace them forward through the following 30 years to the peace settlement of 1998. That 
settlement rested on two pillars. The first was new political institutions which included guaranteed representation of all significant parties in the Northern Ireland government. It firmly institutionalized the power of oppositional forces. The second was conflict resolution measures, including major reforms of policing and the withdrawal of troops from the streets. That is, the settlement secured an end to violent conflict by addressing two major issue areas that had been important to the establishment of the civil rights movement in the first place and that had become its primary focus by 1969 .

Given how important these issues were in the settlement that brought a negotiated end to violence, the continuities in movement goals and demands may be as important as the changes. These continuities are directly related to the distinctive political dynamics at work in divided societies where differential access to state power and institutions, and control of the means of legitimate coercion, are at the heart of political disagreement and conflict. When the legitimacy of the state is contested it calls into question its right to monopolise the forces of coercion. In these circumstances political mobilization of a minority through peaceful protest is much more likely to be superseded by violent conflict. While violent conflict brings with it an escalation of demands, partly because of the intensified need to sustain morale, solidarity, and commitment in very difficult circumstances, the key goals that motivated the initial protests and dominated the peaceful phase of contention may well remain at the heart of armed groups' goals and aims, even if intensified rhetoric can obscure this. In excavating and tracing continuities in goals and aims from the earliest stages of mobilization through the most intense phase of radicalization we might ask which of these goals armed militants retain from the early stages of mobilization and which they abandon. Research should focus especially on the negotiating positions adopted. It is only here that goals and aims crystallize in a way that allows us to clearly trace the continuities with previous peaceful phases of contention. Bargaining positions, even if they are communicated indirectly, and even if negotiations are tacit, provide a crucial site at which to understand strategic interactions between challengers and targets and to 'unpack the decision-making processes within movements and authorities alike' (Turner and De Fazio, in this volume). Tracing these continuities might help to identify the underlying issues that run through all of these phases of mobilization, that help to power a violent challenge to the state but that were also present in the reformist phase and are therefore susceptible to resolution through negotiated compromise rather than revolutionary transformation. 


\section{Works Cited}

Adams, Gerry. 1986. The Politics of Irish Freedom. Dingle: Brandon Books.

An Phoblacht. 1972. An Phoblacht, 24 December.

Arthur, Paul. 1974. The People's Democracy 1968-73. Belfast: Blackstaff Press.

Bosi, Lorenzo. 2006. 'The Dynamics of Social Movement Development: Northern Ireland's Civil Rights Movement in the 196os'. Mobilization 11.1: 81-100.

Bosi, Lorenzo. 2007. 'Social Movement Participation and the "Timing” of Involvement: The Case of the Northern Ireland Civil Rights Movement'. In Research in Social Movements, Conflicts and Change, Volume 27, ed. Patrick G. Coy. Bingley: Emerald, 37-61

Bosi, Lorenzo. 2008. 'Explaining the Emergence Process of the Civil Rights Protest in Northern Ireland (1945-1968): Insights from a Relational Social Movement Approach1'. Journal of Historical Sociology 21.2-3: 242-271.

Bosi, Lorenzo. 2016. 'Incorporation and Democratisation: The Long Term Process of Institutionalisation of the Northern Ireland Civil Rights Movement'. In The Consequences of Social Movements, ed. Lorenzo Bosi, Marco Giugni, and Katrin Uba. Cambridge: Cambridge University Press, 338-36o.

Bosi, Lorenzo, and Stefan Malthaner. 2015. 'Political Violence'. In The Oxford Handbook of Social Movements, ed. Donatella della Porta and Mario Diani. Oxford: Oxford University Press, 439-451.

Bosi, Lorenzo, Chares Demetriou, and Stefan Malthaner, eds. 2014. Dynamics of Political Violence: A Process-oriented Perspective on Radicalization and the Escalation of Political Conflict. Burlington: Ashgate.

De Fazio, Gianluca. 2007. 'Police Knowledge Revised: Insights from the Policing of the Civil Rights Movement in Northern Ireland'. In Research in Social Movements, Conflicts and Change, Volume 27, ed. Patrick G. Coy. Bingley: Emerald, $63-87$

De Fazio, Gianluca. 2009. 'Civil Rights Mobilization and Repression in Northern Ireland: A Comparison with the US Deep South'. The Sixties: AJournal of History, Politics and Culture 2.2: 163-185.

De Fazio, Gianluca. 2013. 'The Radicalization of Contention in Northern Ireland, 1968-1972: A Relational Perspective'. Mobilization 18.4: 475-496.

Della Porta, Donatella. 1995. Social Movements, Political Violence, and the State: A Comparative Analysis of Italy and Germany. Cambridge: Cambridge University Press.

Derry Journal. 1952. Derry Journal, 19 March.

Derry Journal. 1968. Derry Journal, 26 November.

Dooley, Brian. 1998. Black and Green: The Fight for Civil Rights in Northern Ireland and Black America. London: Pluto. 
Ellison, Graham, and Martin, Greg. 2000. 'Policing, Collective Action and Social Movement Theory'. British Journal of Sociology 51.4: 681-699.

Hancock, Landon. 2014. 'We Shall Not Overcome: Divided Identity and the Failure of NICRA 1968'. Ethnopolitics 13.5: 501-521.

Hanley, Brian. 2013. "The Needs of the People”: The IRA Considers Its Future, 1967-68'. Saothar 38: 83-90.

Hewitt, Christopher. 1981. 'Catholic Grievances, Catholic Nationalism and Violence in Northern Ireland during the Civil Rights Period: A Reconsideration'. British Journal of Sociology 32.3: 362-380.

Hewitt, Christopher. 1983. 'Discrimination in Northern Ireland: A Rejoinder'. British Journal of Sociology 34.3: 446-451.

Kovalcheck, Kassian A. 1987. 'Catholic Grievances in Northern Ireland: Appraisal and Judgment'. British Journal of Sociology 38.1: 77-87.

Maney, Gregory M. 2000. 'Transnational Mobilization and Civil Rights in Northern Ireland'. Social Problems 47.2: 153-179.

Maney, Gregory M. 2007. 'From Civil War to Civil Rights and Back Again: The Interrelation of Rebellion and Protest in Northern Ireland, 1955-1972'. In Research in Social Movements, Conflicts and Change, Volume 27, ed. Patrick G. Coy. Bingley: Emerald, 3-35.

Maney, Gregory M. 2012a. 'Agreeing for Different Reasons: Ideology, Strategic Differences, and Coalition Dynamics in the Northern Ireland Civil Rights Movement'. In Strategy in Action: Movements and Social Change, ed. G.M. Maney, R. Kutz-Flamenbaum, D. Rohlinger, and J. Goodwin. Minneapolis: University of Minnesota Press.

Maney, Gregory M. 2012b. 'The Paradox of Reform: The Civil Rights Movement in Northern Ireland', Research in Social Movements, Conflicts and Change, Vol. 34, ed. Sharon Erickson Nepstad and Lester R. Kurtz. Bingley: Emerald, 3-26.

McAdam, Doug. 1983. 'Tactical Innovation and the Pace of Insurgency'. American Sociological Review 48.6: 735-775.

McAdam, Doug, Sidney Tarrow, and Charles Tilly. 2001. Dynamics of Contention. Cambridge: Cambridge University Press.

McCann, Eamonn. 1993. War and an Irish Town. London: Pluto.

Mulholland, Marc. 2000. Northern Ireland at the Crossroads: Ulster Unionism in the O'Neill Years, 196o-9. New York: St. Martin's.

Ó Dochartaigh, Niall. 1999. 'Housing and Conflict: Social Change and Collective Action in Derry in the 196os'. In Derry and Londonderry: History and Society, ed. Gerard O'Brien. Dublin: Geography Publications, 625-645.

Ó Dochartaigh, Niall. 2005. From Civil Rights to Armalites: Derry and the Birth of the Irish Troubles. Basingstoke: Palgrave Macmillan. 
Ó Dochartaigh, Niall. 2011. 'Together in the Middle: Back-Channel Negotiation in the Irish Peace Process'. Journal of Peace Research 48.6: 767-780.

Ó Dochartaigh, Niall. 2015. 'The Longest Negotiation: British Policy, IRA Strategy and the Making of the Northern Ireland Peace Settlement'. Political Studies 63.1: 202-220.

Ó Dochartaigh, Niall. 2016. 'Northern Ireland since 1920'. In The Princeton History of Modern Ireland, ed. Richard Bourke and Ian McBride. Princeton: Princeton University Press, 141-167.

Ó Dochartaigh, Niall, and Lorenzo Bosi. 2010. 'Territoriality and Mobilization: The Civil Rights Campaign in Northern Ireland'. Mobilization 15.4: 405-424.

O'Hearn, Denis. 1983. 'Catholic Grievances, Catholic Nationalism: A Comment'. British Journal of Sociology 34.3: 438-445.

Patterson, Henry. 2008. 'The British State and the Rise of the IRA, 1969-71: The View from the Conway Hotel'. Irish Political Studies 23.4: 491-511.

Prince, Simon. 2007. Northern Ireland's '68: CivilRights, Global Revolt and the Origins of the Troubles. Dublin: Irish Academic Press.

Prince, Simon, and Geoffrey Warner. 2012. Belfast and Derry in Revolt: A New History of the Start of the Troubles. Dublin: Irish Academic Press.

Purdie, Bob. 1988. 'Was the Civil Rights Movement a Republican/Communist Conspiracy?' Irish Political Studies 3.1: 33-41.

Purdie, Bob. 1990. Politics in the Streets: The Origins of the Civil Rights Movement in Northern Ireland. Belfast: Blackstaff Press.

Tilly, Charles. 2003. The Politics of Collective Violence. Cambridge: Cambridge University Press.

Tilly, Charles, and Sidney Tarrow. 2007. Contentious Politics. Boulder, CO: Paradigm Publishers.

White, Robert W.1989. 'From Peaceful Protest to Guerrilla War: Micro-mobilization of the Provisional Irish Republican Army'. American Journal of Sociology 94.6: 1277-1302.

Whyte, John. 1983. 'How Much Discrimination Was There Under the Unionist Regime, 1921-68?' In Contemporary Irish Studies, ed. Tom Gallagher and James O'Carroll. Manchester: Manchester University Press, 1-36.

Wood, Elisabeth. 2003. Insurgent Collective Action and Civil War in El Salvador. New York: Cambridge University Press. 


\section{$3 \quad$ Vacillators or Resisters?}

The Unionist Government Responses to the Civil Rights

Movement in Northern Ireland

Erin-Beth Turner and Gianluca De Fazio

\section{Introduction}

How do authorities respond to social movement tactics, campaigns, and demands? Early research on social movement outcomes typically focused on the characteristics of the challengers (e.g. the size of protests, the number and type of tactics adopted, the goals and ideologies of protest campaigns, etc.) to address this key question. This strand of research aimed to analyse the strategies adopted by authorities to deal with protesters, from symbolic concession and co-optation to resistance and outright repression, by examining mostly movement-centric variables (for an early review of this literature, see Giugni 1998). This relatively static and reactive view of states responses, however, has been recently challenged by various scholars (see Bosi, Giugni, and Uba 2016). A growing wealth of scholarship is now inspecting the strategic interactions between social movements and systems of authority (e.g. Duyvendak and Jasper 2015; for a review, see Bosi and Uba 2016), attempting to unpack the decision-making processes within movements and authorities alike. In The Civil Rights Movement and the Logic of Social Change, Joseph Luders further expanded on how to assess social movement outcomes by focusing on target action motivations. While not the first scholar to note the lack of target-centric theorizing (e.g. Burstein and Linton 2002; Andrews 2004), Luders was the first one to explicitly detail how to analyse targets' role. Examining the Civil Rights Movement in the United States in the 196os, he argued that social movement success could be predicted by estimating target perception of disruption and concession costs (Luders 2010: 1-5). He contended that both movements and third parties, like countermovements and the media, should be examined to determine the perception of costs by movement targets, differentiating between movement demands. Based on these assessments, targets are predicted to act according to one of four ideal typical responses (detailed below).

In this chapter, we apply Luders' model of rational disruption and concession costs to analyse the unionist government responses to the civil rights 
movement (CRM) in Northern Ireland. More specifically, we adopt Luders' analytic design and adapt it to the Northern Ireland context to examine the evolution of the Five-Point Plan put forth by Prime Minister Terence O'Neill in November 1968. We estimate disruption and concession costs of the Unionist cabinet relative to two specific civil rights demands (fair access to housing and universal suffrage), to test the empirical validity of the framework. Close readings of historical documents and primary sources unveil the decision-making process of the targets of the CRM in Northern Ireland.

This chapter thus transposes the analytical framework proposed by Luders into the novel setting of Northern Ireland. This case study raises important theoretical and empirical questions: was rational cost evaluation the primary mechanism behind target responses in Northern Ireland? In the context of a society riven by an ethnonational divide, are target decisions still mostly based on a conscious calculation of concession and disruption costs? Does the activation of competing ethnonational identities and claims alter the perceptions of political threats and therefore the ideological/emotional evaluation of concession and disruption costs by various state actors?

Luders' focus on targets agenda, motivations, and rational evaluations represents an innovative way of looking at social movement outcomes. As far as we know, this chapter is the first attempt to inspect the consequences of the CRM in Northern Ireland from this original theoretical perspective. We believe that Luders' framework is very promising in proposing better explanations of social movement outcomes, even though it requires some modifications to broaden its analytical power. In particular, we will argue that emotional and ideological costs need to be recognized and factored in the decision-making processes to provide a fuller account of movementauthorities strategic interactions.

\section{Theoretical Framework}

Luders $(2006,2010)$ contends that target action is motivated not by ideology or emotion, but by a rational assessment of potential disruption and concession costs of different courses of action. Disruption costs are those directly caused by a movement: whether stemming directly or indirectly from social movement actions, the movement causes these costs. This variable measures the amount of leverage a movement has, or the amount of pressure it can exert on its targets. Concession costs are the 'actual or 
anticipated losses resulting from acceding to movement demands' (Luders 2010: 3). The degree of vulnerability of a target is also a key factor to understand its calculation of costs, which explains why identical tactics from the same movement may affect different targets in different ways (Luders 2010: 7). The interactions between disruption and concession costs are summarized in the target classification matrix shown below. This table predicts target response, and therefore movement success, through targets' perception of costs.

Table 3.1 Predicted Responses to Movement Actions

\begin{tabular}{lll}
\hline & Low Concession Costs & High Concession Costs \\
\hline Low Disruption Costs & $\begin{array}{l}\text { Conformers: Target will } \\
\text { conform to local customs. }\end{array}$ & $\begin{array}{l}\text { Resisters: Target will offer } \\
\text { solid resistance to move- } \\
\text { ment goals. }\end{array}$ \\
High Disruption Costs & $\begin{array}{l}\text { Accommodators: Target will } \\
\text { Vacillators: Target will } \\
\text { concede to movement. } \\
\text { concessions, negotiation } \\
\end{array}$ & and repression. \\
\hline
\end{tabular}

Source: Adapted from Luders 2010: 5

Depending on the targets evaluation of concessions and disruption costs, four different types of responses can be predicted: Conformers, Accommodators, Resisters, and Vacillators. Luders used in-depth qualitative analysis (internal documents, interviews, newspaper articles) to understand what weighs on targets in regard to specific movement demands. He analysed the CRM in the United States to show how different targets - be they political authorities (Luders 2010) or businesses (Luders 2006) - acted upon these costs evaluations in the decision-making process.

In his efforts to maintain target decision-making as rational, Luders, however, underestimates the emotional and ideological contributions to target actions. He aims to illustrate that targets are not monolithic political or economic structures acting only as the system allows, nor are they 'irrational' actors responding solely to prejudiced beliefs. While we agree that targets are comprised of a set of rational players, in much the same way as social movements are, to deny the ideological or emotional connections to or against a cause is to limit the theory's applicability. The introduction of cost-benefit reasoning is necessary for understanding target reactions to movement tactics and, thus, predicting movement success; yet, neglecting the effect of ideological or emotional ties substantially weakens the model's effectiveness. 
Social movement research has abundantly showed the role of emotions (e.g. Goodwin, Jasper, and Polletta 2009; Flam and King 2007) and ideology (e.g. Oliver and Johnston 2000; Zald 2000) in movement decision-making processes. In fact, emotions 'are a core part of action and decisions, which we analysts ignore at our peril. Actions, whether consciously made as choices or not, come with long lists of potential risks, costs, and benefits. We need to include the emotional risks, costs, and benefits because these help shape actions and choices' (Jasper 2011: 298). While research applies these lenses almost exclusively to social movement actors, in this chapter we propose to examine the emotional/ideological cost of actions and decisions to state actors too. Rather than taking away rationality from target decision-making, this additional analytic dimension acknowledges that real-world decisions are not absolute processes, but often the result of an interactive compromise between 'rational' costs evaluations and emotional and ideological beliefs, thus broadening the applicability of Luders' approach.

\section{Methodology}

The first step in testing a theory's applicability is a 'most similar' case study research design (Gerring 2007). If the theory works in the new environment, then further stepwise-dissimilar case studies can advance the realm of its empirical validity (Seawright and Gerring 2008). Northern Ireland and the southern United States have been consistently compared within a 'most similar' case research design (see De Fazio 2009, 2012; Rose 1976), due to their being divided along ethnic or racial lines, respectively, making this case study an apt one to assess Luders' theory. Moreover, this case is a good test of the analytical power of this framework, as the Five-Point Plan, the main object of this study, was itself the result of negotiations and concessions between the Stormont and Westminster cabinets. According to this and other perspectives emphasizing agency and strategic interaction, state actors should be analytically treated as 'players', as well as 'arenas' where conflicts and compromises are central features of the decision-making process (Duyvendak and Jasper 2015: 9-11). This study thus further explores the actor-based approach embraced in this volume, as it also tries to contextualize the power dynamics behind state responses to contentious politics.

The guiding methodology for analysis in this project involves processtracing (Bennett 2010). Process-tracing focuses on the mechanisms of change within a case, herein policy reform. Using a variety of in-depth sources, and temporal sequencing within a clearly defined model like 
Luders', process-tracing can successfully assess case variables. Typically, it examines intervening variables to identify a causal mechanism. However, this chapter applies Luders' model to the Northern Ireland case, hence using process-tracing to corroborate Luders' hypothesized causal mechanisms of decision-making and evaluate its strength and limitations (Bennett 2010). A close reading of historical documents, including cabinet documents, internal letters, and concurrent interviews aims to unveil the rational motivation behind targets' decision-making processes and cost estimation, ascertaining the sources of different and countervailing pressures, and how reluctant government officials perceived and acted on them. Furthermore, the documents and interviews demonstrate how it is the interplay of concession and disruptions costs, together with the vulnerability of the targets, which will determine what category the target falls into. By considering the interplay of pressure and relief offered to targets, a picture of each decision's price in the target's eyes will emerge.

\section{Analysis: The Five-Point Reform Package}

As Luders (2010:7) points out, rather than viewing movements as single-goal monolithic entities, it is important to recognize their separate goals to properly estimate the specific costs perceived by targets for each movement demand. When it emerged in the late summer of 1968 , the CRM in Northern Ireland had three main objectives: ending discrimination in employment, equalizing access to public housing for the Irish Catholic minority, and universal suffrage (see Ó Dochartaigh, in this volume). Here, we specifically examine the latter two goals, as they were strictly related. Local voting in Northern Ireland was ratepayer-based, thus unbiased housing allocation was vital to proper representation in government (Campaign for Social Justice 1969: 13).

\section{The Civil Rights Movement Campaign}

The civil rights march on 5 October 1968 and the subsequent formation of People's Democracy (PD) were particularly influential in the Five-Point Plan's passage. The 5 October march in Derry is commonly recognized as the key event in the civil rights campaign against the injustices in housing allocation, employment, and enfranchisement (Purdie 1990: 159). Those attending the march included three British Labour and Stormont MPs and an RTÉ television crew. Organized by the Derry Housing Action Committee (DHAC) and supported by the Northern Ireland Civil Rights Association 
(NICRA), the march was promised retaliation by the loyalist organization of the Apprentice Boys of Derry (Deutsch and Magowan 1973:10). This tactic was common for loyalists, as it provided the Royal Ulster Constabulary (RUC), the police force in Northern Ireland, a reasonable prediction of public disruption, violence, and property damage (Farrington 2008: 529). For example, a civil rights march planned on 24 August 1968 was rerouted by the RUC and banned from entrance in most of the city of Dungannon (Sterritt 1968). Though billed as maintaining order, ${ }^{1}$ the CRM accused the RUC tactic of banning, or carefully rerouting, their marches as purposefully stifling the civil rights campaign. ${ }^{2}$

In a move typifying future governmental actions, on 3 October, Minister of Home Affairs William Craig had announced a parade ban in Derry's Waterside area and city centre, utilizing the public disorder threat as a justification. NICRA and DHAC chose to continue as planned, encountering RUC blockades. However, what separated this interaction from a simple reroute were the RUC baton-charging the civil rights marchers, captured by the Irish RTÉ television, leading to international news coverage. The police brutality left several protesters injured, including MPs, and resulted in two days of rioting between the RUC and Derry's Catholic residents (Deutsch and Magowan 1973: 10-11). International news coverage increased pressure on Westminster (see Maney, in this volume), and that escalating pressure factored prominently into the reform package's creation and passage.

Only four days later, the student-organized PD formed in Belfast (Arthur 1974). About 2000 students from Queen's University of Belfast organized a march in response to the recent police brutality. Ian Paisley and his loyalist supporters forced the already-rerouted march away from Shaftesbury Square, but a three-hour sit-in occurred when students met the police behind City Hall, at which point Paisley also moved to City Hall. Most students returned to campus and decided to form PD. This increased peaceful, radical mobilization placed further stress on Stormont, trapped between their loyalist voter bloc and the movement's ever-increasing disruption costs. ${ }^{3}$ This latter cost would soon intensify, as the CRM proved to be capable to compel Westminster into action.

1 'Public order was kept due to the civil rights march being re-routed, a step taken solely in the interests of law and order [...] Police intervention was based solely on their duty to keep the peace and not in any way on party or sectarian grounds' (PRONI 1968c).

2 Martin Melaugh, http://cain.ulst.ac.uk/events/crights/chron.htm.

3 As Ó Dochartaigh noted, the civil rights 'campaign proved impossible to repress or ignore. It exerted pressure on the Unionist government of Northern Ireland [...] The pressure operated on the ground, and also via media coverage, through Westminster and Dublin' (2005: 19). 
As a response to the wave of civil rights contention, on 22 November 1968, Prime Minister O'Neill released a Five-Point Plan aiming to improve equality in housing allocation, introduce an ombudsman to deal with complaints, and review the Special Powers Act. The plan contained a very limited voting reform, as it eliminated the company vote, but failed to grant universal suffrage in local elections, one of the most important requests of the CRM. The Five-Point Plan thus sidestepped the issue of full enfranchisement, while allowing Stormont to claim formal support for voter equality. The content of these proposed reforms is also interesting because the release of the plan divided the CRM, emphasizing the ideological and tactical rift between $\mathrm{PD}$ and other civil rights organizations. While moderate groups like NICRA responded to the plan by calling a truce, PD planned a controversial march (Purdie 1990: 212-213) that would contribute to radicalizing the political situation in Northern Ireland (De Fazio 2013, 2014; Bosi and Davis, forthcoming).

\section{The Five-Point Plan: Origins and Development}

On 13 November 1968, Craig announced a ban on all non-customary marches and parades in Derry for one month. Excluding 'customary' marches protected loyalist parades, thus ensuring recently established CRM marches remained the true target of the ban. A later letter by the RUC's Chief Inspector detailed the meeting between senior RUC officers and government officials, including Craig, to determine the ban's extent. Initially, the Londonderry police officers argued that 'the march [organized by NICRA in Derry to take place on 16 November] should be permitted to proceed along the full route' proposed by the organizers, but Craig responded with letters from loyalist groups warning of retaliation should the march proceed as planned (Kennedy 1968a). This spurred the police to re-route the march. Craig then went on to 'initiate a discussion on the question of a ban of all processions and meetings'. The Chief Inspector reminded Craig that 'it is clear that the police did not advise you to impose a ban or, indeed, to interfere with the marchers at all' (Kennedy 1968a; emphasis added). The ban on civil rights marches was thus largely inspired by a single cabinet member, Craig, rather than derived organically from the RUC.

In a meeting at 10 Downing Street on 4 November 1968 among several Stormont and Westminster cabinet members, just nine days before the meeting with the senior RUC officials, Craig had expounded on the importance of the Special Powers Act at the time, citing potential IRA involvement in the movement. The meeting was attended by O'Neill and 
various Stormont cabinet members, as well as by British Prime Minister Wilson. Meeting minutes report that Craig argued that:

If circumstances were normal most of the various regulations under the Acts could have been put into cold storage, but, unfortunately, some disquieting news about I.R.A. policy had come to light which gave grounds for thinking that a new campaign of violence might be mounted [...] Mr. Craig gave other details of I.R.A. activities in Northern Ireland to illustrate the need for retaining the Special Powers legislation, which he considered indispensable in present circumstances. (PRONI 1968b)

Later, the British Minister of State, Education and Science, Alice Bacon, stressed that:

In Great Britain there was today, thanks to the television coverage of the Londonderry Riot, a strong feeling supporting the demand for 'one man - one vote' [...] She had difficulty in understanding Mr. Craig's argument about 'dust bin' functions; if in fact local authorities were to be given such exiguous duties surely there could be no objection to allowing everybody to vote in Council elections. (PRONI 1968b)

She reiterated the pressure put on the issue earlier in the meeting by Wilson, exacerbated by Great Britain's popular support for the issue, pushing for full enfranchisement. Craig retorted that power should be taken away from local government and transferred to Stormont:

The emphasis so far had been on reducing numbers [of local government representatives] but must now be switched to a consideration of the functions which it was proper to ask Local Government to carry out in the future. There were arguments [made by Craig] for transferring the responsibility for some of the more important functions to the Northern Ireland Government leaving local authorities with such minor services as street-lighting and refuse collection. (PRONI 1968b)

Craig aimed not just to reduce the number of locally elected officials, but, more importantly, to reduce their overall power. Thus, even if the CRM had gained its equal voting demand, Craig's proposal would have essentially rendered the local vote less consequential. He then established a timetable for this project, vis-à-vis 'one man, one vote': 
The aim was to complete the Local Government investigation within a period of three years [...] [Craig] found it difficult to speculate on what the franchise should be in the new conditions after re-shaping. If, for example, the new local authorities were to be entrusted with only the simplest functions, such as refuse collection, capable of being financed entirely out of the rates there could clearly be a case for a ratepayers' franchise. Northern Ireland was accused of resisting a move towards one man - one vote but it should be realized that as more and more houses were built the discrepancy between the size of the two franchises was always diminishing [...] [Craig] thought that when the re-distribution of functions as between Stormont and the local authorities was settled the matter could be re-examined - particularly if Stormont were seen to be taking over functions from local councils. (PRONI 1968b)

It is clear that, even when openly criticized before Wilson and O'Neill, Craig maintained that there was little difference between 'one man, one vote' and ratepayer/company votes, wherein housing determines voting abilities and landlords are granted more voting power than tenants. Craig held that power should be removed from local government over the next three years, at which time the issue of enfranchisement may be raised again.

Up to this point, Craig can still fit within Luders' cost assessment model. He may aim to gain power by transferring local government's responsibilities to Stormont. Considering his future actions makes this motivation less likely, however, and Craig emerges as a potential contradiction of Luders' prediction. His refusal to concede to the CRM even when his position would suffer as a result, and his lifelong opposition to the movement despite high disruption and concession costs over time, fall outside of the model's predictions. Craig's outspoken resistance led to his dismissal and subsequent power loss. However, he gained notoriety outside Stormont. Once dismissed, he led the Ulster Loyalist Association. In 1972, when Stormont was suspended leaving Northern Ireland under direct British rule, he left the Ulster Unionists to form the Vanguard Unionists. Craig not only offered 'durable resistance' to the CRM while in office, eventually losing his cabinet position, but continued to oppose it years later. His legacy is as a hard-line Unionist (see Watson 2013).

It is clear that in this instance Craig was torn between letters from loyalist supporters representing a potential threat to his political position, and the increasing disruption costs of the civil rights demonstrations. Based on Luders' rational model, Craig should be a 'vacillator', yet he consistently embodies a 'resister', in that his policy initiatives 'offer durable opposition 
to [the] movement'. Luders fails to correctly assess this target's response. Craig may be a case of ideological or emotion-based decision-making taking priority over cost assessment, particularly when we consider the direction of his political career after losing his position in the government. Even decades later, Craig felt a stronger allegiance to the British crown rather than Northern Ireland. ${ }^{4}$ This points more to an ideological belief and emotional attachment, than a careful cost-benefit analysis.

\section{External Pressure from Westminster}

In a Stormont cabinet meeting on 20 November 1968, just two days before the reform's passage, policy reform and possible legislative actions were discussed vis-à-vis the current Northern Irish and British policymakers. The primary concern of the cabinet meeting is the maintenance of law and order in Derry, specifically as related to enforcing the ban on all demonstrations within Derry's walls (PRONI 1968a). ${ }^{5}$ The RUC Chief Inspector argued that the ban was unenforceable and that 'further really firm police action could lead to the most serious and prolonged disorder in Londonderry and elsewhere [...] The police view was given that unless the heat could be taken out of events by political means, the law and order situation could get completely out of control' (PRONI 1968a).

This is of particular importance, touching directly upon potential disruption costs mentioned in the previous meeting. The relentless stream of civil rights demonstrations gave Northern Ireland an appearance of instability, presenting a power threat should Westminster deem it necessary to intervene (see Warner 2005: 17-23). At Wilson's request, O'Neill, Craig, and Minister of Commerce Brian Faulkner, had already met with him to discuss the situation. At that meeting, Wilson repeatedly expressed this threat. First, in the opening of the meeting Wilson immediately mentioned that the situation embarrassed not only Stormont, but himself and his colleagues, and that 'the United Kingdom government did not need to get involved in a constitutional crisis in order to exert its will on Northern Ireland but could have recourse to other possibilities, for example, the financial contributions made to Northern Ireland expenditure', which he called 'generous' (PRONI 1968b). Judging the 'Northern Ireland scene' as 'irksome,

4 'The government was not loyal to the crown. The government compromised the crown' (BBC 2011).

5 The memo first lists all present MPs, then begins with 'The Maintenance of Law and Order in Londonderry', indicating the issue's importance for cabinet members. 
including the Londonderry situation and the Local Government franchise', Wilson further stated that the Special Powers Act, which Craig strenuously defended, required a special exception in the international Human Rights agreement the United Kingdom had recently signed (PRONI 1968b). This 'weakened the United Kingdom's standing abroad and gave other countries an excuse to criticize' (PRONI 1968b). The CRM thus proved to be capable to threatening Westminster's international reputation directly.

British Home Secretary Callaghan had also explicitly asked to prioritize the local government franchise over job creation as Stormont's 'prime objective' during the 4 November meeting. ${ }^{6}$ Wilson then threatened Stormont with 'complete liquidation of all financial agreements with Northern Ireland' should the voting matter remain unresolved (PRONI 1968b). Thus, the actions of the CRM cost Stormont directly, and also presented a larger financial burden should the instability maintain its level. Even greater than the financial threat, however, was the concrete possibility of a direct power loss. Under Section 75 of the Government of Ireland Act, 'the United Kingdom has residual responsibility [...] [for] Northern Ireland's [...] internal affairs' and while Wilson 'recognized that the issues under discussion were the constitutional responsibility of the Northern Ireland Government, [they were] subject, however, to the residual rights of the United Kingdom Government' (PRONI 1968b).

At that very 20 November Stormont cabinet meeting, Craig pointed out that removing the ban might upset the loyalist movement. The minutes indicate that Craig 'expressed great concern that, if the ban were to be removed at this stage, elements hostile to the Civil Rights demonstrators might take the law into their own hands' (PRONI 1968a). The cabinet minutes continue that it was the 'general opinion of [other] Ministers, however, that the police advice that they simply could not enforce the ban could not be ignored' (PRONI 1968a). Craig is corroborated in a letter from Chief Inspector Kennedy dated 25 November 1968, wherein the Chief Inspector comments on oppositional forces' inability to distinguish between CRM and IRA. groups,

6 The minutes record the Home Secretary's comments as follows: 'Many people in Northern Ireland seemed to think that new jobs constituted the prime objective of Government policy but so far as the United Kingdom administration was concerned, there were other matters that also seemed important, e.g. the local government franchise. He did not see how the Prime Minister could possibly defend at Westminster such things as the company vote and the failure in Northern Ireland to grant the local government vote to all over 21 years of age. If Northern Ireland were to concede only the abolition of the multiple vote then it was natural that attention should focus on the question of adult suffrage.' 
and thus their perception as a constitutional threat (Kennedy 1968b). ${ }^{7}$ Rather than decrease tension or gain loyalist support, the ban on marches placed the cabinet in a precarious political situation. As the civil rights machination kept a constant state of political instability in Northern Ireland, the unionist government had to respond to the protests, due to concession costs of loyalist violence and disruption costs of Westminster intervention.

The cabinet minutes identify potential financial and power losses from instability, detailing the pressure exerted by Westminster, in particular Wilson, over Stormont. A much-discussed letter from Wilson stating that 'if [Stormont] refused to accept universal adult suffrage, it would be imposed by Westminster', best exemplifies London pressure on the Stormont cabinet (PRONI 1968a). O'Neill also reminded the cabinet that 'if the current agitation was not brought under control, a situation could arise in which Mr. Wilson could say law and order in Northern Ireland was not being maintained', and Westminster would intervene (PRONI 1968a). This explicit loss of power further reinforces how CRM's creating an image of instability represented a sizeable disruption cost for the unionist regime.

\section{Cost Evaluations and the Five-Point Plan}

The majority of ministers at the cabinet meeting asserted that introducing profound and radical legislative change during what was continually referred to as a time of 'duress', would be unwise and 'most unacceptable' (PRONI 1968a). The ministers' perception of voter reform concession costs makes them reluctant to pass effective legislative reform. This placed the cabinet in the almost impossible position of having high disruption costs of ongoing movement actions (political instability and Westminster threat to reduce Stormont power) on the one hand, and high concession costs in response to universal adult enfranchisement (loyalist counterdemonstrations and voter backlash) on the other hand. Clearly, the cabinet was torn between impending universal adult suffrage legislation and an inability to ensure its enforcement without violent disturbances. They faced scrutiny on the issue from all sides, even their own party, and had to find the 'politically feasible' solution: a reform package that avoided dealing directly with universal suffrage.

7 Craig repeatedly claimed, both publicly and privately, that the CRM was an IRA front. He claimed the Derry march was primarily IRA members when Wilson suggested eliminating the Special Powers Act. The meeting minutes recorded Craig thusly: 'Baulked in its efforts to use Republican Clubs as recruiting grounds by the ban on such clubs, [... the IRA] had turned its attention to the civil rights movement'. 
Even though it may have been unenforceable, the ban on marches was enacted to appease the loyalist countermovement and maintain party support, demonstrating the unionist cabinet concession costs evaluation. Revoking the ban would endanger the loyalist voting bloc necessary to maintain the majority needed for the cabinet to retain power. The threat was actually twofold, as a reform with an impact as wide as 'one man, one vote' would likely incur a backlash from loyalist supporters, and enfranchise a larger section of the Irish Catholic minority hostile to unionist domination. Stormont's Chief Whip explicitly referenced this concession cost, arguing that if the cabinet 'announced a 'package' of proposals but did not deal with the franchise, the current agitation would continue and the pressures, internal and external, would not be relieved. [...] Roman Catholic votes must be secured if the constitutional position was to be maintained' (PRONI 1968a). The concession costs were thus quite high. While housing, employment, and minor local governmental restructuring were issues which would lose votes from loyalists if the cabinet acted in favour of movement demands, none were as volatile as 'one man, one vote'. The constant references to the 'wrong time' for this change reflected cabinet members' high level of vulnerability to both internal and external pressures. The cabinet was in a weak position as the disruption and concession costs had put its members into a corner, forcing them into action.

According to Luders' cost-benefit matrix, a target facing both high concession and high disruption costs will vacillate between minor or token concessions, and movement repression. The ban indicated in the letter from the RUC Chief Inspector to Craig was a concrete method of repression against the CRM, trying to suppress one of their most successful tactics. ${ }^{8}$ Thus, we see the first step in vacillation between repression and token reform that Luders predicts. The enfranchisement bill which was drafted in the end, the Electoral Law Act (Northern Ireland) 1968, Chapter 20, addressed a range of movement demands: the permanent Boundary Commission directly dealt with the accusations of unionist gerrymandering, and it abolished the University as well as the Business vote in Stormont elections (Deutsch and Magowan 1973: 13). The Five-Point Plan, publicly announced by O'Neill on 22 November, touched on housing, local government reforms, and the Company vote, but never mentioned the 'one man, one vote' issue.

8 The effectiveness of the civil rights marches are further demonstrated by the fact that the British Prime Minister was involved enough to send letters and privately meet with O'Neill to discuss enfranchisement, specifically mentioning in the meeting the marches and their mishandling by the RUC. 
Failure to include it makes the act a 'limited reform', as it ameliorated minor aspects, while ignoring the movement's primary demand. Rather than the emotional or ideological reasoning usually assigned to target reactions, Luders allows us to see how this reform package was the result of a build-up of pressure from Westminster, as well as third parties like the loyalist countermovement and international media, and a consistent level of pressure from the CRM.

\section{Conclusions}

The analysis of decision-making processes is becoming more prominent in social movement scholarship (e.g. Jasper and Duyvendak 2015). However, studies of the target's decision-making process (usually not the analytical focal point) largely ignore the nuances of why targets align against issues, whether on an ideological basis, or through rational cost evaluation (see Uba 2016). Because analyses typically adopt a movement-centric perspective, target decisions are often depicted as a force to react $t o$, rather than rationally motivated decisions. If the target's decision is incorporated, it is as a result of the political structure itself, either allowing or disallowing concessions, not governing bodies (targets) evaluating actions on a case-by-case basis.

This chapter examined the Five-Point Reform package to examine the validity of Luders' model outside of its original application, and to assess whether targets rationally evaluate action costs in their decision-making process. The target actions analysed in this case correspond with Luders' theory, generally upholding the proposed cost-evaluation model. Prime Minister O'Neill and most of his cabinet turned out to be 'vacillators', attempting to navigate high disruption and concession costs by alternating limited concessions and repression towards the CRM and its main demands. However, the model fails to correctly assess Craig's political actions as Minister of Home Affairs during the second half of 1968. While the model would predict him to follow Prime Minister O'Neill's lead as a vacillator, Craig exhibited consistent oppression and resistance to the CRM, even after losing his position, unto his deathbed. Craig's case demonstrates that while targets do rationally assess options based on cost calculations and vulnerabilities, completely eliminating ideological and emotional influences on those decisions is imprudent.

Depending on time frame and domain, Craig's case could be construed differently, however. An argument could be made that, despite his resistance costing him power, Craig was still following Luders' model: once he lost 
his cabinet position, he sought external power by maintaining his strong resistance stance, finding himself at the forefront of the loyalist political movement. Then, when Stormont was dissolved and Westminster imposed direct rule on Northern Ireland in 1972, he was in a prime position to fight for status in the resulting power vacuum. Delving into Craig's political ambitions after his dismissal might thus yield a different interpretation of his actions and decisions. However, this does not negate the fact that Luders' model would predict Craig acting as a vacillator while a minister in Stormont, yet, he is a hard-line resister prior to and after his dismissal.

Luders' approach opens new avenues of research: by considering the target, rather than simply the movement, scholars can begin to understand under which circumstances social movement actions may have the best result. When the target is analytically unpacked as both a player and an arena (Duyvendak and Jasper 2015), with motivations that transcend governmental structures, weighing costs and ideological beliefs, we eliminate the monolithic 'target' and can attune movement analysis to the target. Moreover, movements themselves can learn from and incorporate this perspective, and Luders breakdown of targets, into their tactical decisions. Actors participating in contentious politics, be they movements, countermovements, authorities, or third parties, utilize some rational evaluation to determine the best course of action from their vantage point. This is even true in the context of an ethnically divided society like Northern Ireland, where the unionist government's early responses to the civil rights requests of public housing and universal suffrage can be correctly interpreted as that of a vacillator. The mix of repression and limited reform was the rational response to a very vulnerable political situation with high disruption and concession costs and no easy way out. The re-emergence of the loyalist threat increased significantly the concessions costs for O'Neill, who would a few months later resign as Prime Minister, while opening up the political space for ethnic entrepreneurs like Ian Paisley and William Craig.

Divided societies then add an additional layer of complexity to contentious politics. In the context of competing ethnonational mobilizations and a state not fully legitimized (see Bosi and De Fazio, in this volume), conceding to movement demands might represent a particularly costly strategy for the state. If concessions to movement requests are perceived to impinge directly, or even symbolically, on an opposite ethnonational faction, then the threat of political violence could be substantially higher than in other democratic regimes, making concession costs prohibitively high. Ethnonational claims can in fact elicit ideological and emotional reactions that make compromises very hard to reach, inevitably altering 
the vulnerability of targets, as well as their 'rational' evaluation of costs. Future research should attempt to replicate this model in similar contexts to further advance our understanding of the dynamics of contentious politics in divided societies.

\section{Works Cited}

Andrews, Kenneth. 2004. Freedom Is a Constant Struggle: The Mississippi Civil Rights Movement and Its Legacy. Chicago: University of Chicago Press.

Arthur, Paul. 1974. The People's Democracy 1968-73. Belfast: Blackstaff Press.

BBC. 2011. 'Obituary of Former Vanguard Leader Bill Craig'. BBC.com, 26 April. http://www.bbc.co.uk/news/uk-northern-ireland-13191551.

Bennet, Andrew. 2010. 'Process Tracing and Causal Inference'. In Rethinking Social Inquiry: Diverse Tools, Shared Standards, ed. Henry Brady and David Collier. Lanham, MD: Rowman \& Littlefield, 207-220.

Bosi, Lorenzo, and Donagh Davis. Forthcoming. "What Is to Be Done?": Agency and the Causation of Transformative Events in Ireland's 1916 Rising and 1969 Long March'. Mobilization.

Bosi, Lorenzo, and Katrin Uba. 2016. 'Political and Institutional Confrontation'. In Protest Cultures: A Companion, ed. Kathrin Fahlenbrach, Martin Klimke, and Joachim Scharloth. Oxford: Berghahn, 451-461.

Bosi, Lorenzo, Marco Giugni, and Katrin Uba, eds. 2016. The Consequences of Social Movements. Cambridge: Cambridge University Press.

Burstein, Paul, and April Linton. 2002. 'The Impact of Political Parties, Interest Groups, and Social Movement Organizations on Public Policy: Some Recent Evidence and Theoretical Concerns'. Social Forces 81.2: 380-408.

Campaign for Social Justice. 1969. Northern Ireland:The Plain Truth. $2^{\text {nd }}$ ed. Dungannon: CSJ.

De Fazio, Gianluca. 2009. 'Civil Rights Mobilization and Repression in Northern Ireland: A Comparison with the US Deep South'. The Sixties: AJournal of History, Politics and Culture 2.2: 163-185.

De Fazio, Gianluca. 2012. 'Legal Opportunity Structure and Social Movement Strategy in Northern Ireland and Southern United States'. International Journal of Comparative Sociology 53.1: 3-22.

De Fazio, Gianluca. 2013. 'The Radicalization of Contention in Northern Ireland, 1968-1972: A Relational Perspective'. Mobilization 18.4: 475-496.

De Fazio, Gianluca. 2014. 'Intra-Movement Competition and Political Outbidding as Mechanisms of Radicalization in Northern Ireland, 1968-1969'. In Dynamics of Political Violence: A Process-Oriented Perspective on Radicalization and the 
Escalation of Political Conflict, ed. Lorenzo Bosi, Chares Demetriou, and Stefan Malthaner. Farnham: Ashgate, 115-136.

Deutsch, Richard, and Vivien Magowan. 1973. Northern Ireland 1968-73: A Chronology of Events: Volume 1, 1968-71. Belfast: Blackstaff Press.

Duyvendak, Jan Willem, and James M. Jasper, eds. 2015. Breaking Down the State: Protestors Engaged. Amsterdam: Amsterdam University Press.

Farrington, Christopher. 2008. 'Mobilisation, State Crisis and Counter-Mobilisation: Ulster Unionist Politics and the Outbreak of the Troubles'. Irish Political Studies 23.4: 513-532.

Flam, Helena, and Debra King, eds. 2007. Emotions and Social Movements. London: Routledge.

George, Alexander, and Andrew Bennett. 2004. Case Studies and Theory Development in the Social Sciences. Boston: MIT Press.

Gerring, John. 2007. 'Is There a (Viable) Crucial-Case Method?' Comparative Political Studies 40.3: 231-253.

Giugni, Marco. 1998. 'Was It Worth the Effort? The Outcomes and Consequences of Social Movements'. Annual Review of Sociology 24: 371-393.

Goodwin, Jeff, James Jasper, and Francesca Polletta, eds. 2009. Passionate Politics: Emotions and Social Movements. Chicago: University of Chicago Press.

Jasper, James. 2011. 'Emotions and Social Movements: Twenty Years of Theory and Research'. Annual Review of Sociology 37: 285-303.

Jasper, James, and Jan Willem Duyvendak, eds. 2015. Players and Arenas: The Interactive Dynamics of Protest. Amsterdam: Amsterdam University Press.

Kennedy, A. 1968a. Letter from A. Kennedy, Chief Inspector of the RUC, to the Minister of Home Affairs, Belfast, 22 November 1968. HA/32/2/30, Public Record Office of Northern Ireland.

Kennedy, A. 1968b. Letter from A. Kennedy, Chief Inspector of the RUC, to the Minister of Home Affairs, Belfast, 25 November 1968. HA/32/2/28, Public Record Office of Northern Ireland.

Luders, Joseph. 2006. 'The Economics of Movement Success: Business Responses to Civil Rights Mobilization'. American Journal of Sociology 111.4: 963-998.

Luders, Joseph. 2010. The Civil Rights Movement and the Logic of Social Change. New York: Cambridge University Press.

Ó Dochartaigh, Niall. 2005. From Civil Rights to Armalites: Derry and the Birth of the Irish Troubles. Cork: Cork University Press.

Oliver, Pamela, and Hank Johnston. 2000. 'What a Good Idea! Ideologies and Frames in Social Movement Research'. Mobilization 5.1: 37-54.

PRONI. 1968a. 'Conclusions of a Meeting of the Cabinet', 20 November. CAB/4/1418, Public Record Office of Northern Ireland. 
PRONI. 1968b. 'Meeting at 10 Downing Street on $4^{\text {th }}$ November, 1968'. Northern Ireland Information Office. CAB/4/1413, Public Record Office of Northern Ireland. PRONI. 1968c. 'Press Release', 26 August 1968. Ministry of Home Affairs. $\mathrm{CAB} / 9 / \mathrm{B} / 205 / 7$, Public Record Office of Northern Ireland.

Purdie, Bob. 1990. Politics in the Street: The Origins of the Civil Rights Movement in Northern Ireland. Belfast: Blackstaff Press.

Rose, Richard. 1976. 'On the Priorities of Citizenship in the Deep South and Northern Ireland'. Journal of Politics 32.2: 247-291.

Seawright, Jason, and John Gerring. 2008. 'Case Selection Techniques in Case Study Research: A Menu of Qualitative and Quantitative Options'. Political Science Quarterly 61.2: 294-308.

Sterritt, G. 1968. County Inspector of the RUC in County Tyrone, 'Public Order Act (Northern Ireland) 1951', 23 August 1968. HA/32/2/27, Public Record Office of Northern Ireland.

Uba, Katrin. 2016. 'Protest against the School Closures in Sweden: Accepted by Politicians?' In The Consequences of Social Movements, ed. Lorenzo Bosi, Marco Giugni, and Katrin Uba. Cambridge: Cambridge University Press, 159-184.

Warner, Geoffrey. 2005. 'Putting Pressure on O'Neill: The Wilson Government and Northern Ireland 1964-69'. Irish Studies Review 13.1: 13-31.

Watson, Garry. 2013. "Meticulously Crafted Ambiguities": The Confused Political Vision of Ulster Vanguard'. Irish Political Studies 28.4: 536-562.

Zald, Mayer. 200o. 'Ideologically Structured Action: An Enlarged Agenda for Social Movement Research'. Mobilization 5.1: 1-16. 


\title{
$4 \quad$ White Negroes and the Pink IRA
}

\author{
External Mainstream Media Coverage and Civil Rights \\ Contention in Northern Ireland ${ }^{1}$
}

\section{Gregory Maney}

As emphasized in the introductory chapter to this volume, levels and forms of ethnonationalist contention vary over time and are shaped by contingent historical contexts. Local, national, and transnational processes may all impact contention. Surprisingly little scholarship has focused upon how transnational processes have shaped political contention in Northern Ireland.

Social movements scholars studying other cases have devoted considerable attention to international mainstream media coverage as a transnational process. Regarding forms of contention, McAdam and Rucht (1993) highlight the international media as a non-relational mechanism that sends protest ideas across borders. Even in the context of new social media, Aday et al. (2013) stress the ongoing importance of the international mainstream media to bringing about the Arab Spring. With respect to the outcomes of contention, some studies find that the mainstream media hinders the ability of social movements to achieve their objectives (e.g. Solomon 2001; Rosie and Gorringe 2009) while others find the opposite relationship (Layton 2000).

Below I develop an analytical framework that uses the concepts of movement and media-generated master frames to help explain these contrasting findings. An analysis of external media coverage of civil rights contention in Northern Ireland lends empirical support for the approach. By impacting the legitimacy of the British and the Northern Ireland governments, coverage that aligned movement and media master frames initially generated moral and material pressure for concessions to civil rights demands. As the forms, leaders, and goals of civil rights protests shifted, and as the Northern Ireland government developed its communications infrastructure and strategy, a change in media master frames no longer generated this pressure. If anything, external coverage legitimated repressive responses to the civil rights movement. Beyond demonstrating the relevance of a transnational process to the outcomes of contention, the analysis presented

1 This research was funded, in part, through a grant from the National Science Foundation (SES-0958743). 
in this chapter yields three additional, significant findings that highlight the interplay between agency, culture, and structure. First, local actors were often successful in their efforts to encourage or discourage external journalists to align movement and media master frames in their coverage of contention. Second and consistent with the analysis provided by Turner and De Fazio (in this volume), the ability of external media coverage to legitimate or de-legitimate movements, opponents, and targets by generating moral shock suggests that responses to contentious events are often deeply emotion-laden and identity-driven. Third, changes in the forms, goals, and primary participants over the course of contention (as noted by Ó Dochartaigh and White and Demirel-Pegg, both in this volume) can influence which master frame is applied by journalists.

This analysis was made possible through collecting a sample of news coverage of civil rights contention in Northern Ireland by external media outlets along with discussions of external media communications strategies by participants in contention using several sources, including clippings of and references to coverage found in the archives of organizations based in Northern Ireland (Linen Hall Library Political Collection and an anonymous collection) and the United States (American Irish Historical Society), the archives for the Stormont cabinet (Public Records Office of Northern Ireland), a regular feature in the Derry Journal on external media coverage, a search of two issues per week of The Times (of London), and the memoirs of participants in the civil rights movement, opponents, targets and bystanders. The findings of others scholars (e.g. Wilson 1995; Ward 1984) collecting similar news coverage samples are referenced below and cross-validate my analysis of predominate coverage frames at different points of contention.

\section{Movement and Media-Generated Master Frames}

Snow and Benford (1992: 138) theorize that master frames are responsible for the emergence of international cycles of protest. The authors state that like collective action frames, master frames are 'modes of punctuation, attribution and articulation'. The key difference between the two lies in that master frames 'may color and constrain those of any number of movement organizations'. Drawing from Tarrow (1983: 36-39), the authors describe international protest cycles as 'sequences of escalating collective action that are of greater frequency and intensity than normal' that occur on an international level. 
Like activists, journalists frame collective action. Just as movements can develop frames that spawn a host of imitators and produce an international protest cycle in the process, journalists can develop frames for covering these same movements; frames that are used repeatedly in coverage of subsequent movements emerge during the cycle. Media master frames are likely to emerge during international protest cycles. Time and space constraints compel journalists to develop news routines (Tuchman 1973). The standardization of coverage of protests is particularly necessary during periods when many such events occur. Because of the exigencies of news routines, journalists look for hooks for their pieces. Furthermore, the more the frame is used, the more its potency increases. In an effort to make foreign events interpretable to domestic audiences, reporters often apply the same themes and topics used in coverage of domestic news (Gans 1980; Ward 1984). For all of these reasons, coverage that is faithful to a frame underlying previous coverage of similar protests is likely to appeal to mass audiences.

Differences between movement and media master frames can have important implications for contention. In a longitudinal study of the German peace movement, Cooper (2002) finds that divergences between the collective action frames used by activists and the coverage frames used by the media resulted in lower levels of mobilization. Not all movements taking place during a protest cycle are framed the same way by the mainstream media. Divergences are most likely to occur when organizations within a movement make demands for fundamental social change, or engage in violent or destructive tactics. Events involving such organizations are likely to be covered using extremist, deviant, and dismissive frames (e.g. Hertog and McLeod 1995; Boykoff 2006). By impacting claims, demands, and tactics, changes in the organizational composition and the power dynamics within a movement can result in changes in the media master frame that is applied. It is also possible that contention itself can have radicalizing effects upon actors previously making moderate claims and demands and engaging in non-violent tactics (e.g. Tarrow 1994; Kriesi, Koopmans, Dyvendak, and Giugni 1995; Alimi, Demetriou, and Bosi 2015; Ó Dochartaigh and White and Demirel-Pegg, both in this volume). Such radicalizing effects can result in a divergence between movement and media frames to the detriment of the movement.

In addition, non-violent movements can be eclipsed by, as well as conflated with, armed rebellions whose actors can attempt to legitimate their violence by referencing claims and demands by non-violent movements. Newspaper editions, radio broadcasts, and television programmes have limited space/time within which to present news (Gans 1980; Ryan 1991). Thus 
the chance of any particular event getting in the news is a function not only of its own news value, but also of the sheer number and news value of other potential news events that day. An event that would ordinarily be news can be crowded out by bigger news (Baumgartner and Jones 1993). The space/ time available for coverage of foreign political events is generally smaller than the space/time devoted to domestic affairs. Moreover, political events in over 160 countries compete with one another for attention. As a result, only events considered to be highly newsworthy and easily interpretable to domestic audiences receive coverage. This makes it likely that non-violent protests, if mentioned, are covered as a minor subset of news items focusing upon armed rebellion. To maintain thematic consistency, journalists are likely to apply the same frame to protesters and armed insurgents.

With regard to the possible influence of media coverage on outcomes, Rojas (2006) hypothesizes that protests can bring about social change through de-legitimating targets, imposing material costs, or encouraging targets to mimic or imitate other comparably positioned actors making concessions to protesters. I argue that media master frames that converge with movement master frames are likely to contribute to each of these mechanisms of pressure. Conversely, media master frames that diverge from movement frames are likely to impose material costs upon movements, de-legitimate them, and encourage targets to mimic other comparably positioned actors repressing protesters. During international cycles of protest, coverage of events by mainstream media outlets based outside of the primary geographic site of contention is particularly likely to influence outcomes. Beyond interstate competition for spheres of influence (Layton 2000), outside media coverage can also influence outcomes by prompting external intervention and international isolation, damaging international legitimacy, jeopardizing inward investment, and deepening intra-party divisions (e.g. Risse-Kappen, Ropp, |and Sikkink 1999; Maney 2000; Turner and De Fazio, in this volume).

While the concept of an international media master frame may suggest an inability of participants in contention to shape coverage, this is not the case. Because of the possible consequences of coverage, movements, targets, and opponents often develop communication strategies. Media master frames are either harnessed or challenged depending upon their perceived favourableness (Maney, Woehrle, and Coy 2005). Savvy activists will harness movement master frames that have converged with media master frames so as to garner sympathetic coverage of their events. Conversely, savvy targets and opponents will challenge these media master frames and harness media master frames that diverge from movement master frames. 
Often this involves efforts to persuade journalists that the movement is not what it seems, and is more like a movement to which negative media master frames have been applied. The implementation of these conflicting communication strategies constitutes a discursive form contention - a battle of words for the hearts, minds, and choices of frames of journalists. I now present a case study that inspired the development of this framework and illustrates its potential.

\section{External Mainstream Coverage of Civil Rights Contention2}

External media coverage of Northern Ireland politics during the late $1960 \mathrm{~s}$ and early 1970 s provides an example of the interactive relationship between contention and transnational processes. Coverage of protest events taking place in other societies not only shaped the goals and forms of contention prevailing in Northern Ireland, but also influenced the frames applied by external media outlets. External media coverage was initially favourable to the civil rights movement and helped to generate pressure on behalf of its demands. Later coverage, however, was less favourable and de-legitimated the movement.

Two master frames were developed with regard to mainstream media coverage of protests during the 1950 os and 1960s. First, as an early riser in the international protest cycle, the civil rights movement in the United States influenced other movements' framing both domestic and abroad. The movement's framing also became dominant among mainstream media outlets covering civil rights protests. Second, the emergence of the New Left in the United States influenced student movements' framing in other societies (McAdam and Rucht 1993). In contrast to civil rights contention, the mainstream media, on the whole, diverged from the movement's framing in favour of extremist, deviant, and trivializing frames (Gitlin 1980). Both media master frames were applied to civil rights contention in Northern Ireland. Both were cultivated by opposing actors. Coverage using the different media master frames had contrasting effects upon the civil rights movement's ability to achieve its goals.

2 This study examines coverage of contention in Northern Ireland by mainstream media outlets located outside of Northern Ireland, including outlets in Great Britain and the Republic of Ireland. Because many consider Northern Ireland to be a part of the United Kingdom or, alternatively, a part of the Republic of Ireland, I have chosen to use the term external rather than international. 


\section{Media Framing of Early Mass Civil Rights Contention in Northern Ireland}

The reformist, non-violent orientation of the US Civil Rights Movement, combined with the Cold War-infused salience of egalitarian and democratic discourses, legitimated the movement in the eyes of influential mainstream media outlets throughout the world (Layton 2000). Dooley (1998: 108) suggests that the initial, positive media coverage of the civil rights movement in Northern Ireland was a welcomed, but largely unanticipated product of contention. In contrast, my research indicates that while journalists may have independently drawn parallels between the struggles of African Americans and Irish nationalist activists, the latter left little to chance.

During the first mass civil rights march in Northern Ireland from Coalisland to Dungannon in August of 1968, Fionbarra Ó Dochartaigh received loud applause when he declared, 'We are the white negroes of Northern Ireland' (Farrell 1988: 57). Key organizers had their sights focused upon producing favourable international publicity. An organizer of the march, Austin Currie (1998:16), writes: 'A prime objective of the proposed civil rights marches was to publicise internationally injustices to Northern Ireland and to force the British government to intervene to redress them'. External media coverage of protests, therefore, was envisioned as the primary tool for generating pressure on behalf of civil rights demands.

International condemnation over the actions of the police force in Birmingham, Alabama, and other instances of brutality against civil rights protesters in the US offered an important tactical lesson; repression of peaceful demonstrators asking for equal rights would prompt extensive outside media coverage and widespread condemnation of the government. Organizers of the 5 October 1968 civil rights march in Derry/Londonderry were fully aware that their publicly stated plans to march through the Diamond would probably produce a violent response by the police and loyalist civilians (McCann 1993: 92-97). As anticipated, a repressive response to the Derry/Londonderry march by the Northern Ireland Minister of Home Affairs William Craig and the Royal Ulster Constabulary brought a worldwide outpouring of criticism and demands for British government intervention. The publicity surrounding the event underscored the efficacy of taking to the streets and remaining non-violent in the face of repression (e.g. Ó Dochartaigh 1994: 26-27).

Most observers agree that in the year following 5 October, the civil rights movement in Northern Ireland had won 'the media war' (e.g. Moloney 
1998: 139-141; Dooley 1998: 108-110). External television coverage focused on images of brutality against non-violent demonstrators (Farrell 1976: 247; Guelke 1988: 86). After examining coverage in ABC, NBC, and CBS evening news broadcasts, Newsweek, and Commonweal, Andrew Wilson (1995: 21) concluded that police assaults on civil rights marchers received extensive coverage in the United States. Cued by civil rights activists and eager to make foreign events intelligible to a domestic audience, these outlets highlighted similarities between African Americans and Catholic nationalists. By highlighting minority grievances, newspapers outside of Northern Ireland also legitimated their civil rights demands.

From October of 1968 through August of 1969, the mainstream international media largely dismissed allegations by Unionists that the civil rights movement in Northern Ireland consisted of communists, republicans, Trotskyites, and anarchists. Northern Ireland Minister of Home Affairs William Craig's repeated assertion that 'the Pink IRA' was behind the 5 October march was derided as paranoid fantasy. An editorial in the Baltimore Evening Sun on 15 October stated: 'Take some civil rights protesters. Place them in reach of policemen who tend to 'overreact'. Throw in an underground conspiratorial movement on which to blame all the blood and broken heads that result from the proximity of the first two. Where are you? Chicago? No, this time the scene is Londonderry, N. Ireland' (Derry Journal 1968a). The piece was not exceptional in rejecting efforts by Stormont officials and loyalists to apply extremist frames to civil rights activists.

Even after Stormont announced a series of reforms on 22 November 1968, the media continued to cast a critical eye upon the government. During an evening news broadcast, $\mathrm{ABC}$ covered a civil rights march from Belfast to Derry/Londonderry in early January of 1969 . With demonstrators singing 'We Shall Overcome' in the background, the television network's reporter Bill Beutal noted that 'some observers have compared the plight of the ghetto residents in Northern Ireland to ghetto residents in this country' (Ward 1984: 204). Overall, external media coverage of political contention in Northern Ireland initially favoured the civil rights cause. The consequences of civil rights activists' winning the early rounds of media contention will now be examined.

A consensus exists among both participants and observers of the period that international publicity surrounding civil rights events in late 1968 placed significant pressure upon Stormont to enact reforms. Civil rights activists like John Hume (1998:4) believe that it was the critical component to success: 
The positive effect of October 5 was very strong. It had a worldwide impact through television. It led to the establishment of the Derry Citizens' Action Committee of which I was proud to be a member. Harnessing the maximum strength of the city against injustice, the DCAC achieved more change than had been achieved in the 50 years previous in 48 days in response to the massive national and international pressure created by the consequences of October 5 .

The effects of coverage upon domestic and international public opinion prompted the British government to intervene. Negative publicity beyond the United Kingdom jeopardized Stormont's international standing and, in the process, threatened the vitality of an economy heavily dependent upon external investment. Within Northern Ireland, negative publicity deepened splits among Unionists. Each of these sources of pressure is now reviewed in turn.

First, negative publicity prompted British government intervention by de-legitimating Stormont. By wrapping its demands in sacrosanct principles of British political culture, the civil rights movement in Northern Ireland ensured sympathetic media coverage that, in turn, placed moral pressure upon the Labour Party-led British government to intervene on its behalf. With the emphasis upon equal rights as British citizens, government officials could not easily turn a blind eye to the forceful denial of civil rights within its own backyard. With the public focused upon events in Northern Ireland, feelings of hypocrisy helped to override a longstanding aversion to intervening in Irish affairs.

Beyond moral pressure, negative publicity created practical political incentives for intervention. Inaction threatened not only a possible revolt by Labour backbenchers at Westminster, but also a backlash at the polls. Just as the call for equal rights under the law by African Americans generated considerable sympathy and support among liberal Americans, similar demands by the nationalist minority in Northern Ireland resonated widely and deeply with British public opinion. In the words of the Northern Ireland Minster of Commerce and future Prime Minister, Brian Faulkner (1978: 48):

It sounded to a world attuned to such protests, a positive humanitarian cry from an oppressed people. It also seemed to involve a very basic right [...] Many well-meaning but ill-informed people, even in Britain, were under the impression that the 'evil Unionist government' had made it illegal for Catholics to vote in elections. 
By creating moral shock (Jasper and Poulsen 1995), coverage of police brutality placed British public opinion even more firmly behind the demonstrators and their demands. The British government could only ignore these sentiments at its peril.

Stormont found itself unprepared to fight a war of words with civil rights activists. Ministers and civil servants were soon overwhelmed in trying to respond to a barrage of criticism issued from media outlets throughout the world. By deliberately avoiding issues of partition, civil rights activists had rendered standard Unionist counter-frames obsolete. Without sufficient public-relations capacities to counteract civil rights propaganda, Stormont capitulated to British government demands for changes, announcing a series of reforms on 22 November 1968.

The reforms package, however, did not alleviate the pressure caused by negative publicity. The pattern established in late 1968 of negative international publicity, ineffective public-relations efforts, and policy concessions would repeat itself. British media coverage of violence against civil rights demonstrators participating in the march from Belfast to Derry/ Londonderry in early January of 1969 gave the government another black eye. Stormont responded by trying to develop its publicity machinery. Less than a week after the march, the cabinet decided to provide the RUC with a senior press officer from the Government Information Service until the recently created Police Public-relations Officer position could be filled (PRONI 1969a:1-2). Agreeing that 'publicity arrangements must be reviewed and improved both at the Government and Party levels', the cabinet also reactivated its publicity committee. Only by March of 1969, however, did the government begin to formulate a coherent strategy. The following month, O'Neill committed the government and the Unionist Party to universal franchise in local elections.

With the ousting of O'Neill as Prime Minister in late April 1969 and the strengthening of the government's public relations capacities, loyalists intensified their efforts to block reforms. When dramatic political events on the streets of Northern Ireland once again focused the international media spotlight on Northern Ireland, the usual pressures for concessions to the civil rights movement resurfaced. British media coverage of the August 1969 riots prompted the Labour government to once again intervene. British Prime Minister Harold Wilson stated that:

[E]very London news reporter and leader-writer, whatever the political complexion of the paper for which he was writing, was appalled by the situation he had to describe. It was the culmination of three centuries 
of atavistic intolerance. It was also the culmination of nearly fifty years of the unimaginative inertia and repression of successive, unchallenged and, because of Ulster's history unchallengeable, Ulster Unionist Governments. (1971: 692)

With the British Prime Minister and the British Home Secretary knocking at the door, Northern Ireland Prime Minister James Chichester-Clark agreed to announce further concessions. The cabinet agreed to set up an advisory body to review the organization and practices of the police forces. Two months later, the Hunt Commission would recommend the disbanding of a part-time, auxiliary police force, the B Specials, and the disarming of the RUC. More immediately, on 19 August, the British and Northern Ireland governments issued a joint declaration stating their mutual agreement that 'it is vital that the momentum of internal reform shall be maintained' (Deutsch and Magowan 1973: 152). By the end of the month, the two governments issued another joint statement. The communiqué focused upon both implementing promised reforms and taking additional initiatives envisioned, such as introducing legislation to establish 'machinery for the investigation of citizens' grievances against local authorities or other public authorities'.

As evidenced by its preoccupation, Stormont would not have readily signed the statement in the absence of increased British government pressure resulting from negative publicity. The day before the joint communiqué, the Minister of Development, Brian Faulkner, called for 'an urgent examination of the publicity machinery and the methods needed to improve the Government's public-relations' (PRONI 1969b: 2). In addition, the Prime Minister asked the Publicity Committee of the cabinet to meet later to 'consider how outside professional advice could best be harnessed'. Beyond the threats posed by British intervention, negative international publicity placed other policy priorities in jeopardy.

Second, negative publicity imposed material costs. As a devolved government, Stormont officials worried primarily about how the British government would respond to international criticism. The government, however, also had a more direct economic stake in keeping its own reputation in good standing among foreign nations. Negative publicity stemming from civil rights contention threatened to undermine the government's efforts to attract inward investment. Speaking to a Publicity Association luncheon, the Minister of Commerce, Brian Faulkner, voiced his concern:

Bad publicity costs nothing. And it travels further, faster and with more immediate effect than good publicity. That is a hard fact of life illustrated 
only too clearly by the news coverage given to the recent disturbances in Londonderry. 'Image' is a much overworked word. But it is vitally important that a true image of Northern Ireland is projected to the world at large. This is not just a question of pride or prestige. The picture which others have of Ulster can affect us in a most direct way - financially. (PRONI 1968)

External organizations supporting the civil rights movement like the American Congress for Irish Freedom sought to take advantage of Northern Ireland's external financial dependence by threatening to take legal action against US corporations with operations in Northern Ireland that discriminated against nationalists. Stormont's concerted efforts to counteract the campaign provide evidence of the degree of pressure generated by these activities.

Third, while the case provides support for the expectations that sympathetic external media coverage would create moral and material pressure on behalf of the civil rights movement, there was no support for Rojas' mimicry hypothesis. Nonetheless, the case reveals an additional source of pressure, namely how coverage created a political opportunity for the civil rights movement by deepening ideological and strategic splits among Unionists. Most researchers and participants have stressed the importance of loyalist mobilization in limiting the scope of reforms. Few, however, have highlighted the role of Unionists in promoting reforms. Some Unionist politicians agreed with the depiction of Northern Ireland presented by the outside media and sought to use it to their advantage. Bolstered by the negative external reaction to the events of 5 October, some government officials spoke about the moral imperative of reforms. During a speech to a Unionist gathering at Larne, the Unionist Chief Whip, Roy Bradford, stated:

A turning point has been reached in Northern Ireland's history and if the Unionist Party does not keep abreast of the tide of change they will be swamped by events instead of fashioning them to our own purpose. We have never had a worse press. Our reputation with our fellow-British citizens of the UK has been badly tarnished. Any talk of UDI [Unilateral Declaration of Independence] for Ulster was dangerous lunacy. There is a high road and a low road in politics. The high road is the road of fair play and enlightened government. The low road is the road of repression which ends in anarchy. We must act now to clear our name of any allegations of injustice. To do nothing is to invite shame as well as violence. (Derry Journal 1968b) 
In summary, multiple pressures resulting from external media coverage of civil rights contention between 1968 and 1969 forced Stormont to announce reforms and reaffirm its commitment to implementing them. The lack of similar instances of political accommodation in over 40 years prior to the advent of modern mass communications underscores the importance of external mainstream media coverage to the policy gains achieved by the civil rights movement. Nonetheless, just as this coverage contributed to initial victories, it also contributed to the civil rights movement's subsequent inability to 'maintain the momentum of internal reform' (NICRA 1978: 7).

\section{External Media Framing of Later Civil Rights Contention in Northern Ireland}

As the main forms, demands, and leaders of civil rights protests shifted, the tenor of external media coverage changed. Beginning in 1969, correspondents increasingly focused their attention on violent civil rights protests and outspoken activists using New Left and republican frames. Along with the emergence of armed rebellion in 1970, these developments resulted in the use of extremist, deviant, and trivializing frames in coverage of civil rights activists and events. As a result, the pressure for reforms and for the restraint of repression that outside media coverage had once placed upon Stormont largely dissipated. Just as civil rights activists had cultivated international publicity to promote their objectives, their opponents exploited the sea change to discredit the movement.

As civil rights demonstrations turned increasingly violent in 1969, external media coverage focused upon the actions of protesters rather than their messages. For example, following a civil rights protest in Newry involving violence by a large number of demonstrators on 11 January 1969 , Van Wormer (1998: 46) recalls: 'Predictably the next day's headlines are devastating: "Riot Breaks Out during Civil Rights Protest". The press also began to convey Stormont's spin on events, viewing their assertions as being empirically credible. An article in the Dublin-based Irish Times quoted Northern Ireland's Minister for Home Affairs, Captain Long. Long asserted that the aim of the civil rights protesters 'now appears to be the creation of civic strife in an attempt to disrupt the harmonious relationships which have grown up among all sections of the community in recent years' (Irish Times 1969).

Starting in 1969, a New Left student group, People's Democracy (PD), took the lead in organizing a series of civil rights protests. With striking similarities in opinions, appearances, and actions, foreign correspondents 
drew upon the same frames used to cover student protests at home. The pictures painted were hardly flattering. Weary and wary of student protests in their societies, the mainstream media applied extremist frames when reporting violence by civil rights demonstrators in Northern Ireland. In late April 1969, PD held a sit-down in Lurgan. As the RUC wielded their batons, protesters fought back. Subsequently, PD remarked about the way journalists portrayed the event: "The events at Lurgan during the Easter PD march have been represented by the press as trouble-making, long-haired students being restrained by our peace loving police' (PD Voice 1969: 3).

When some student civil rights activists vocally asserted their socialist agenda, the content of media coverage outside of Northern Ireland became increasingly negative. Their youth and controversial views made good copy. As a result, outside reporters sought them out disproportionately in relation to more conservative civil rights leaders. During her visit to the United States in August 1969, Bernadette Devlin openly advocated a Socialist Workers' Republic of Ireland. A growing number of papers in the US came to agree with the Unionist characterization of the MP as 'Fidel Castro in a miniskirt' (Wilson 1995: 33). During a speech in Detroit as part of a fundraising tour for the civil rights movement, members of the audience heckled Devlin when she called for civil rights in the United States. Devlin responded by having the person employed to sing John McCormack songs sing instead the African American civil rights anthem 'We Shall Overcome' (McAliskey 1988: 87). A number of Irish-American dignitaries seated in the front row refused to stand for the song. After the event a Detroit News staff editorial described Devlin as a 'mini-skirted Danny the Red' (Dooley 1998: 107). Establishment anxieties over social unrest permeated several subsequent features.

Other journalists went beyond Devlin to apply extremist frames to the civil rights movement as a whole. A month after the August riots, the British Daily Mail ran a series of articles entitled 'How World Revolutionaries Took the Lead in Ulster's Civil Rights Struggle: The Professionals behind the Barricades'. Whereas the pre-split republican leadership took great pains to stay in the shadows of the civil rights movement so as not to discredit it, New Left activists like Devlin, Farrell, and McCann basked in the media spotlight, welcoming the opportunity to expound upon their beliefs.

Once international correspondents wielded the red paint, they smeared it rather indiscriminately. After verifying Unionist allegations of communist involvement, the external media increasingly portrayed the Northern Ireland Civil Rights Association (NICRA) as an 'extreme socialist' organization (Farrell 1988: 62). An organizer's report discussed the organization's 'bad 
image': 'Image-wise, NICRA has been accused of being a Republican, Communist or Provisional Front. We are also called "extremists". A lot of this smearing has stuck. So that now the media distinguishes between the early Civil Rights movement and the NICRA of today' (NICRA 1974: 1). Beyond image problems, civil rights organizations faced declining coverage with the emergence of armed rebellion which was generally deemed to be more worthy of coverage.

The outbreak of armed conflict in the early 1970 accelerated the decline in outside media coverage of civil rights events in Northern Ireland. Riots and bombings were deemed more newsworthy than civil rights marches. An NBC correspondent told one researcher: 'We cover Northern Ireland, but the stuff that gets on the air is the rough stuff. If there's something fairly peaceful, or something that involves their parliament, it's hard to get it on' (Epstein 1973: 247). NICRA's campaign to end internment, repeal the Special Powers Act, and secure passage of a bill of human rights at Westminster rarely made the papers. Even statements by those interned often did not make the papers. Two years into the rent and rates strike against interment, NICRA continued to experience difficulties in getting coverage of its campaign (e.g. NICRA 1973a). Paramilitary violence crowded non-violent civil rights events out of the media spotlight.

After 1969, the frames that outside correspondents used to interpret events in Northern Ireland changed. With its soldiers on the streets of Belfast and Derry/Londonderry and its sovereignty under direct challenge, the British mainstream media generally responded to events in Northern Ireland in a nationalistic manner. Reporters mostly portrayed British soldiers as a peacekeeping force. Upon the introduction of internment in August 1971, the British press frequently omitted reference to allegations of the torture of nationalist detainees during interrogations by British officers (see Sunday Times 1972: 289-291; Curtis 1983: 30).

Beyond Britain, armed rebellion also resulted in a changing of frames used by the media to interpret political contention in Northern Ireland. Parallels with the Vietnam War became the primary frame deployed by US correspondents (e.g. Ward 1984: 207). As British soldiers became targets of republican paramilitary operations starting in 1970, the US media drew parallels between British troops in Northern Ireland and US troops in Vietnam. The media also highlighted republican violence against civilians. Whereas mainstream journalists internationally viewed peaceful protests for civil rights as legitimate, they viewed armed challenges to an ostensibly democratic state's sovereignty as illegitimate. Increased political violence in Western societies heightened anxieties and disdain for armed insurgency. 
With the introduction of direct rule in Northern Ireland by the British government in March 1972, Irish republican activities were further de-legitimated. While sometimes criticizing its repressive policies, the Western media generally refrained from a frontal assault on the credibility of the British government and its rule over Northern Ireland. Along with its geopolitical power, the British government's superior public-relations capacities, including control over the BBC's coverage, helped to insure this transformation. Like Stormont did prior to its dissolution, the British government put a self-serving spin on events in Northern Ireland (see ACUJ 1972: 1). As the wave of international media coverage deploying terrorist frames to characterize rebellion in Northern Ireland grew to tidal proportions, the civil rights movement got caught up in the swell.

Just as the international media increasingly red-baited civil rights organizations, it frequently portrayed them as republican fronts. As a consequence, even the most egregious acts of repression against civil rights activists received justification from some quarters of the outside media. An editorial by the Daily Express asserted in regard to NICRA that 'many members of this organization are neither civil nor right. They simply promote the aims of the IRA' (Dooley 1998: 113). The uniform condemnation of the RUC's actions on 5 October 1968, vanished even in coverage of Bloody Sunday - the most repressive response to a civil rights demonstration in Northern Ireland's history. The policy consequences of the shift were equally contrasting.

While sympathetic international media coverage contributed to the ability of the civil rights movement to force Stormont to agree to reforms, subsequent negative coverage alleviated pressures to follow through on promised reforms and to restrain repressive activities. After 1969, the British public's clamour for intervention on behalf of civil rights demands died down. In September 1972, NICRA's Executive Committee introduced a resolution at a special conference stating: 'One of the main tasks facing NICRA is to re-win the support of British democracy [...] for our basic demands. This support was lost through the bombing campaign' (NICRA 1972). NICRA also recognized the success of the British and Northern Ireland governments in promoting the use of anti-extremist frames in outside media coverage (e.g. NICRA 1973b). In an open letter to the press, the Tyrone Regional Executive of NICRA stated:

It must now be obvious that violence in Northern Ireland in opposition to the British Government's policies merely results in the perpetrators being manipulated by that Government to create a climate of opinion favourable to Britain's policy of changing the structures of the old outdated 
system rather than implementing democratic standards of political, administrative and social behaviour. (NICRA 1973b)

Beyond the United Kingdom, international media coverage no longer placed the international reputation of the British government in jeopardy. Reflecting upon the development, NICRA (1978: 46) lamented:

The British Army is free to harass, arrest and brutalise and the UDR is actively encouraged to continue with its policies of sectarian violence. In brief Britain is determined to put the boot in. It is a policy easily justifiable to the world press in the light of seven years of para-military violence.

In the relative absence of negative domestic and international publicity, the British government focused more singularly upon ending rebellion. Subsequent reforms reflected counter-insurgency strategies more than a direct response to civil rights movement demands for the policy changes.

With the resurgence of armed republicanism, Unionists found themselves on more familiar ground. The 'Orange card' could once again be played effectively. Their efforts to both red-bait and republican-bait civil rights organizations contributed to increasingly negative coverage. In the process, moderate Unionist pressure largely dissipated. Efforts to sustain momentum for reforms through the formation of the Alliance Party failed as reflected by its weak showing at the polls. Both parliamentary and extra-parliamentary mobilization resulted in the ascendance of hard-line Unionists in the Orange Order, in the Unionist Parliamentary Party, and in the Stormont cabinet. Unionists' economic fears remained, but armed rebellion, not civil rights mobilization, most threatened inward investment. In the relative absence of external pressures for reform, Stormont opted (until its demise in March 1972) to pursue political and economic stability through intensified repression.

\section{Conclusion}

Social movements research to date assists us in understanding the role of external media coverage in civil rights contention in Northern Ireland during the 1960s and the early 1970s. Media coverage of the civil rights movement in the United States as well as the New Left student movements in Great Britain, France, and elsewhere diffused protest ideas, influencing minority insurgents in Northern Ireland; specifically, what demands 
were made, how demands were framed, and the ways that demands were pursued. At the same time, a closer examination of the Northern Ireland case assists in building social movement theory by helping to explain contradictory findings regarding the effects of media coverage, and by filling in gaps in the literature; gaps such as lack of attention to the communication strategies of movements and their opponents, and the specific mechanisms by which media coverage influences the outcomes of contention. The role of the external media in the dynamics and outcomes of the case studied here mirror those of the first Intifada (see Wolfsfeld 1997), suggesting that ethnonationalist insurgents engaged in political violence are likely to be de-legitimated internationally. Further research is needed to ascertain the generalizability of the findings to other ethnically divided societies.

\section{Works Cited}

ACUJ. 1972. 'Critique of the Critchley Plan for Northern Ireland'. (American Committee for Ulster Justice) Newsletter, 1 July, p. 1.

Aday, Sead, Henry Farrell, Deen Freelon, Marc Lynch, John Sides, and Michael Dewar. 2013. 'Watching From Afar: Media Consumption Patterns around the Arab Spring'. American Behavioral Scientist 57.7: 899-919.

Alimi, Eitan, Chares Demetriou, and Lorenzo Bosi. 2015. The Dynamics of Radicalization: A Relational and Comparative Perspective. New York: Oxford University Press.

Baumgartner, Frank, and Brian D. Jones. 1993. Agendas and Instability in American Politics. Chicago: University of Chicago Press.

Boykoff, Jules. 2006. 'Framing Dissent: Mass-Media Coverage of the Global Justice Movement'. New Political Science 28.2: 201-228.

Cooper, Alice Holmes. 2002. 'Media Framing and Social Movement Mobilization: German Peace Protest against INF Missiles, the Gulf War, and NATO Peace Enforcement in Bosnia'. European Journal of Political Research 41.1: 37-80.

Currie, Austin. 1998. 'Breaching the Walls of Injustice'. Irish News Souvenir Supplement, 5 October, p. 16.

Curtis, Liz. 1983. Ireland: The Propaganda War: The British Media and the Battle for Hearts and Minds. London: Pluto Press.

Derry Journal. 1968a. 'Worldwide Publicity'. Derry Journal, 22 October, pp. 4-5.

Derry Journal. 1968b. Untitled article. Derry Journal, 1 November, p. 4.

Deutsch, Richard, and Vivien Magowan. 1973. Northern Ireland, 1968-73: A Chronology of Events. Belfast: Blackstaff Press. 
Dooley, Brian. 1998. Black and Green: The Fight for Civil Rights in Northern Ireland and Black America. London: Pluto.

Epstein, Edward J. 1973. News from Nowhere: Television and the News. New York: Random House.

Farrell, Michael. 1976. Northern Ireland: The Orange State. London: Pluto.

Farrell, Michael, ed. 1988. Twenty Years On. Dingle: Brandon.

Faulkner, Brian. 1978. Memoirs of a Statesman. London: Weidenfeld and Nicholson.

Gans, Herbert. 1980. Deciding What's News: A Study of CBS Evening News, NBC Nightly News, Newsweek and Time. New York: Vintage.

Gitlin, Todd. 1980. The Whole World Is Watching: Mass Media in the Making and Unmaking of the New Left. Berkeley: University of California Press.

Guelke, Adriane. 1988. Northern Ireland: The International Perspective. Dublin: Gill and Macmillan.

Hertog, James, and Douglas M. McLeod. 1995. 'Anarchists Wreak Havoc in Downtown Minneapolis: A Multi-level Study of Media Coverage of Radical Protest'. Journalism \& Mass Communication Monographs 151: 1-47.

Hume, John. 1998. 'It Was the Worst "Example of Injustice” in that State'. Irish News Souvenir Supplement, 5 October, p. 4.

Irish Times. 1969. Untitled article. Irish Times, 11 January, p. 1.

Jasper, James, and Jane Poulsen. 1995. 'Recruiting Strangers and Friends: Moral Shocks and Social Networks in Animal Rights and Antinuclear Protest'. Social Problems 42.1: 493-512.

Kriesi, Hanspeter, Ruud Koopmans, Jan Willem Dyvendak, and Marco G. Giugni. 1995. New Social Movements in Western Europe: A Comparative Analysis. Minneapolis: University of Minnesota Press.

Layton, Azza Salama. 2000. International Politics and Civil Rights Policies in the United States, 1941-196o. Cambridge: Cambridge University Press.

Maney, Gregory M. 200o. 'Transnational Mobilization and Civil Rights in Northern Ireland'. Social Problems 47.2: 153-179.

Maney, Gregory M., Lynne Woehrle, and Patrick Coy. 2005. 'Harnessing and Challenging Hegemony: The US Peace Movement after 9/11'. Sociological Perspectives 48.3: 357-381.

McAdam, Doug, and Dieter Rucht. 1993. 'The Cross-National Diffusion of Movement Ideas'. Annals of the American Academy of Political and Social Science 528: 56-74.

McAliskey, Bernadette Devlin. 1998. 'A Peasant in the Halls of the Great'. In Twenty Years On, ed. Michael Farrell. Dingle: Brandon Books, pp. 75-88.

McCann, Eamonn. 1993. War and an Irish Town. Boulder, CO: Pluto Press.

Moloney, Ed. 1988. 'The Media: Asking the Right Questions?' In Twenty Years On, ed. Michael Farrell. Dingle: Brandon Books. 
NICRA. 1972. 'Political Statement submitted by the NICRA EC to the Special General Conference of All NICRA Members in Coalisland', 17 September. Northern Ireland Civil Rights Association. Belfast: Linen Hall Political Collection.

NICRA. 1973a. Press statement, c. 1973. Northern Ireland Civil Rights Association. Belfast: Linen Hall Political Collection.

NICRA. 1973b. Letter, 11 October. Northern Ireland Civil Rights Association. Belfast: Linen Hall Political Collection.

NICRA. 1974. 'NICRA Organiser's Report for the April 1974 AGM'. Northern Ireland Civil Rights Association. Belfast: Linen Hall Political Collection.

NICRA. 1978. 'We Shall Overcome': The History of the Struggle for Civil Rights in Northern Ireland 1968-1978. Belfast: Northern Ireland Civil Rights Association, 1978.

Ó Dochartaigh, Fionnbarra. 1994. Ulster's White Negroes: From Civil Rights to Insurrection. San Francisco, CA: AK Press.

PD Voice. 1969. 'Lurgan - Good Friday'. PD Voice, June, p. 3.

PRONI. 1968. 'Speech by the Minister of Commerce, Rt. Hon. Brian Faulkner, DL, MP, at Publicity Association Luncheon in the Midland Hotel at 12:30PM on Tuesday, $22^{\text {nd }}$ October, 1968'. Northern Ireland Information Office. CAB/9B/205/7, Public Record Office of Northern Ireland.

PRONI. 1969a. 'Conclusions of a Meeting of the Cabinet Held at Stormont Castle on Friday, $10^{\text {th }}$ January 1969 at 10:30 am'. Northern Ireland Information Office. $\mathrm{CAB} / 4 / 1426$, Public Record Office of Northern Ireland.

PRONI. 1969b. 'Conclusions of a Meeting of the Cabinet Held at Stormont Castle on Thursday, $28^{\text {th }}$ August 1969'. Northern Ireland Information Office. CAB/4/1469, Public Record Office of Northern Ireland.

Risse-Kappen, Thomas, Stephen C. Ropp, and Kathryn Sikkink. 1999. The Power of Human Rights: International Norms and Domestic Change. Cambridge: Cambridge University Press.

Rojas, Fabio. 2006. 'Social Movement Tactics, Organizational Change and the Spread of African-American Studies'. Social Forces 84.4: 2147-2166.

Rosie, Michael, and Hugo Gorringe. 2009. "'The Anarchists' World Cup": Respectable Protest and Media Panics'. Social Movement Studies 8.1: 35-53.

Ryan, Charlotte. 1991. Prime Time Activism: Media Strategies for Grassroots Organizing. Boston: South End Press.

Snow, David A., and Robert Benford. 1992. 'Master Frames and Cycles of Protest'. In Frontiers in Social Movement Theory, ed. Aldon D. Morris and Carol McClurg Mueller. New Haven, CT: Yale University Press, 133-155.

Solomon, Norman. 2001. "A Different World Is Possible": Porto Alegre vs. the Corporate Media'. Socialism and Democracy 15.2: 25-39.

Sunday Times. 1972. Insight Team, Ulster. London: Penguin. 
Tarrow, Sidney.1983. Struggling to Reform: Social Movements and Policy Change during Cycles of Protest. Ithaca, NY: Western Societies Program, Cornell University. Tarrow, Sidney. 1994. Power in Movement: Social Movements, Collective Action and Politics. New York: Cambridge University Press.

Tuchman, Gaye. 1973. 'Making News by Doing Work: Routinizing the Unexpected'. American Journal of Sociology 79.1: 110-131.

Van Wormer, Katherine Stuart. 1998. 'Protesting for Civil Rights in the US and Northern Ireland: A Personal Reminiscence'. Proteus March: 43-48.

Ward, Ken. 1984. 'Ulster Terrorism: The US Network News Coverage of Northern Ireland, 1969-1979'. In Terrorism in Ireland, ed. Yonah Alexander and Alan O'Day. London: Croom Helm, pp. 198-2015.

Wilson, Andrew J. 1995. Irish America and the Ulster Conflict, 1968-1995. Washington, DC: Catholic University of America Press.

Wilson, Harold. 1971. The Labour Government, 1964-1970: A Personal Record. London: Penguin.

Wolfsfeld, Gadi. 1997. Media and Political Conflict: News from the Middle East. Cambridge: Cambridge University Press. 


\title{
5 'We Are the People'
}

\author{
Protestant Identity and Collective Action in Northern \\ Ireland, 1968-1985
}

\section{Sarah Campbell}

The period after 1968 could be described as one of retreat and political defeat for unionists in Northern Ireland (Gillespie 2007). While the civil rights movement has been thoroughly accounted for (see, for example, Bosi 2006; Prince 2007; Ó Dochartaigh 1997; Purdie 1990), there has been an academic neglect of Protestant protest and collective action in Northern Ireland during the 'Troubles' (with the exceptions of Novosel 2013; Gillespie 2004; Nelson 1984). There have been several occasions during the 35 years of conflict when sections of the loyalist community have tried to use the industrial might of Protestant workers in a national stoppage or strike to achieve a political end, some which have been successful, and others with only a limited success, or unsuccessful. The most successful of these protests was the Ulster Workers' Council strike in May 1974, which brought down the power-sharing executive agreed at Sunningdale. The protests surrounding the Anglo-Irish Agreement a little over a decade later, in 1985-1986, while failing to achieve any political changes, were successful in mobilizing Protestant collective action.

Why were these protests more successful at mobilizing unionists than others during this period? And why was the collective action surrounding the 1985 campaign not as successful as that in 1974 ? This chapter seeks to answer these questions by examining the role of collective memory and its relationship with activism. Using the 1974 and 1985 campaigns as empirical cases, this research will demonstrate how mnemonic processes play a central role in the articulation of narratives for mobilization. I argue that collective memories help to bring the past into the present, and create responsibilities to those who came before. The result is a mutually constituting relationship between memory and activism (Farthing and Kohl 2013), both where an instrumental construction of collective memories reinforces the collective identity process, and where memories of previous mobilizations influence which activities are considered helpful or successful. Memories can also be considered, simultaneously, as outcomes of mobilization and significant factors in shaping further mobilization (Meyer 2006). Drawing on Fredrick Harris's (2006) theory that collective memory frames collective action, this 
chapter probes how political entrepreneurs appropriated the memories and events intrinsic to a Protestant sense of the past and identity, and used them to stimulate collective action and mobilization. It will explore the processes and functions of memory and narratives in divided societies and how they inform each other to explain their significance for mobilization efforts and will suggest that individual participants in these movements were empowered through identifying themselves with history and the sense of making history (Eyerman 2015). The use of historically based collective identities is more significant in deeply divided societies. A defining feature of ethnonationalism is an emphasis on collective memories, shared grievances, and communal claims-making (McGrattan 2013) and a vicious cycle involving identity and retributive collective action becomes almost seamless (Smithey 2012: 87). Furthermore, this ethnonational divide itself became a source of collective identity. The collective identity that was fostered by Protestants between 1968 and 1985 was constructed and reconstructed from origin myths, historical narratives, commentary on contemporary states of affairs and teleological visions, especially as religion served as a resource for identity construction (Smithey 2012: 87). By providing a deeper understanding of the relation between memory and mobilization, this chapter will also question how the politics of memory shapes cultural meaning-making in movements or collective action.

This research draws on a number of qualitative sources: archival materials, secondary sources, newspaper and journal accounts, a semi-structured focus group with nine former loyalists and trade union activists, personal oral testimonies available online, ${ }^{1}$ and autobiographies. Archival research at the Public Records Office of Northern Ireland (PRONI), the Northern Ireland Political Collection (NIPC) at the Linen Hall Library and the Conflict Archive on the internet ${ }^{2}$ supplied valuable documentation on various loyalist groups, particularly the Ulster Workers' Council and Vanguard, and loyalist newspapers, including the Protestant Telegraph, the Ulster Loyalist, and the Loyalist News. I also conducted a four-hour-long focus group with nine former loyalists and trade union activists on the topic of 'How effective has the Protestant working class been at collective action?' in August 2014. ${ }^{3}$

1 Recorded testimonies from activists at a commemoration event on Sunningdale in Belfast on 19 May 2014 are available at: https://audioboom.com/playlists/ 1255041-uwc40-ulster-workers-council-strike-4oth-anniversary-conference-at-qub.

2 Located online at http://cain.ulst.ac.uk/.

3 The participants of the focus group were identified by a 'gatekeeper' who introduced me to those who were willing to participate. I am grateful to Dr Aaron Edwards, who works with members of the loyalist community in his research, for playing this role. 
This allowed for comments on broader issues as well as those specific to both 1974 and 1985 and the collection of some impressions on the ideological and discursive structures shared by participants. What was important with this group was to examine what memories (collective and individual) were discussed and what role the memories played in both mobilizing support and informing repertoires of action. It also allows for an examination of an underestimated aspect of memory and mobilization: constraint within movements. Memory can help collective action by drawing on symbolic material from the past, but at the same time can constrain people's ability to mobilize, imposing proscriptions and prescriptions (Zamponi 2013). This becomes important for understanding why the collective action surrounding the 1985 campaign was not as successful as in 1974 .

\section{Collective Memory, Collective Identity, and Grievances}

Three key areas of social movement study are important for understanding how the past and its public representation influence mobilization, as well as how social movements or collective action participate in the construction of public memory - these include collective memory, collective identity and grievance frameworks, and these three areas of focus are interrelated. A lot of the research has addressed these issues or approaches in paralleled grounds, separate from each other, rather than in conversation with each other. This has the potential of missing the substantial connections between memory, identity and grievances and the way the processes inform each other. In order to understand Protestant mobilization in 1974 and 1985 , it is crucial to examine how their identities were reinforced and institutionalized through collective memory and grievance frames.

\section{Collective Memory}

Collective memories are partial and constructed experiences of the past, inevitably shaped by a standpoint in the present, and also often a vision of the future (Lee and Guobin 2007: 2). Collective memory is not given but socially constructed (Halbwachs 1992: 48). Halbwachs suggests that 'while the collective memory endures and draws strength from its base in a coherent body of people, it is individuals as group members who remember' (1992: 22). It is, of course, individuals who remember, not groups or institutions, but these individuals, being located in a specific 
context, draw on that context to remember or recreate the past. Halbwachs believed that the present generation becomes conscious of itself in counterposing its present to its own constructed past. He argued that through participation in commemorative rituals with group members of the current generation we can recreate through imaginatively re-enacting a past that would otherwise slowly disappear in the haze of time (1992: 24). Collective memory, then, is the result of an interactive process of selecting, processing, and organizing past events or periods within a framework that grants them political or social significance (Gongaware 2003: 32; 2010).

Charles Tilly has alluded to two aspects of memory's politics: both the substantive claims and the action repertoire of contentions are shaped by how and what people retrieve and conceive of their past: 'From the past, people take not only a history of their relations to potential objects of their claims and a more general sense of their own common identity but also histories of the particular forms of claim making they have at their disposal [...] These pasts frame collective ideas of what actions are generally possible, permissible and desirable' (Tilly 1994: 247). Gongaware (2003) agrees with this idea and contends that collective memory processes provide the framework that organizes the past for present use, provides information used for the collective identity process, and aides in the development of unity and continuity.

If we understand memory as social remembering (Misztal 2003) and as a contested struggle over the meaning of the past, then social movements are an important part of that struggle. Social movements make strategic use of the past and are important social forces in carrying the past into the future (Eyerman 2015: 83). They are the bearers and shapers of individual and collective memory (Eyerman 2015: 83). The theory of collective memory and collective action can broaden our understanding of the micro-dynamics of collective action. Just as a group's sense of identity or its political culture may provide a lens through which to interpret grievances and political opportunities, so collective memory can serve similar purposes for social groups by offering solidarity incentives to engage in cooperative action (Harris 2006: 32). Kubal and Becerra (2014) claim that tactical repertoires and cultural repertoires provide the resources needed to construct collective memories, and repertoires empower memory activists to engage the political sphere, create change, and nurture solidarity within movement organization. Collective memories, therefore, are conduits connecting past experiences with present ones in the formation of collective identity. This is important in the collective identity process 
as it provides, through narratives interactively exchanged, an additional source of identity.

\section{Collective Identity}

While changing class structures and political opportunities should be viewed as crucial to the political context in which collective action occurs, alone they are insufficient as explanations for popular mobilization. Political structures may influence, but they do not determine, the values and expectations of social actors. Social movement scholarship has developed the concept of collective identity to analyse movement emergence, mobilization, strategic choices, and cultural effects left unanswered by resource mobilization and political process models (Polletta and Jasper 2001). One important focus of their research explores the sense of unity in a social movement. This unity is the result of a process of collective identity (Melucci 1997). Collective identity is defined as 'individuals' cognitive, moral and emotional connection with a broader community, category, practice, or institution' (Polletta and Jasper 2001: 285). Pre-existing collective identities are often used for mobilization, for the strategic framing of those identities is critical in recruiting members (2001: 291). Similarly, scholars examining collective memory contend that groups of people gain a sense of cohesion through the interactional construction of collective memories (Gongaware 2003). Despite its wide application, collective identity is still a notoriously abstract concept. Flesher Fominaya (2010) suggests that it could be described as a process that is generated through the interaction of movement members as they attempt to mobilize for a shared goal.

To mobilize their groups, ethnic elites aim at creating a collective sense of unity and solidarity amongst their members (Saleh 2013: 164). Collectively significant events can become (selectively) incorporated in social representations that enable the positioning of ethnic identities and leads to the construction of Protestant narratives that shape collective memory and produce specific political identities that are mutually exclusive.

\section{Grievance Framework}

Oberschall (1973) has posited that '[i]deas and beliefs that have a revolutionary potential are usually present and are available for use by a protest leadership. Sentiments of opposition, of being wronged, are also frequently present in the lower orders and can be easily linked with more elaborate ideologies and world views' (quoted in Gamson 1992a: 53). Gamson identifies three 
components of collective action frames ${ }^{4}$ as injustice, agency, and identity (Gamson 1992b: 7). The injustice frames allow movement actors to construct - and ordinary people to make sense of - their grievances through a sense of moral indignation. Injustice frames not only provide evaluations about what is fair, but they also provide activists with a politicized consciousness to challenge whatever perceived harm or suffering they have encountered (Gamson 1992b: 7). Likewise, Jasper (2014) suggests that anger and indignation, the morally grounded form of anger, are crucial to many aspects of protest. They not only motivate participation (Van Stekelenburg and Klandermans 2013), but they direct blame for social problems, create sympathy and admiration for protestors, and guide strategic choices. The mere existence of relative deprivation, however, is not sufficient to mobilize collective action. Transforming such deprivations and grievances into collective action requires a politicization of ethnic identity. As Esman (1994: 28) compellingly argues:

Mobilization is the process by which an ethnic community becomes politicised on behalf of its collective interests and aspirations. This process requires awareness, usually promoted by ethnic entrepreneurs, that political action is necessary to promote or defend the community's vital collective interests. This awareness results in the recruitment of individuals into the movement or into organizations that purport to speak for the movement.

The next sections will examine how important memory processes are in the allocation of meaning to events by Protestants in Northern Ireland to trigger action in 1974 and 1985 . It will suggest that the meaning allocation process takes place in mobilization through grievance articulation, but it will also focus on the mnemonic elements that are involved previous to and alongside the articulation of identity and grievances that trigger mobilization.

\section{Memories, Myths, and 'Ulster Resistance'}

Popular memories of unionist resistance in 1912-1914 emerged as a political and cultural force during the post-1969 period in loyalist communities in

4 Snow and Benford (1992: 133-137) demonstrate that collective action frames - defined as 'action-orientated sets of beliefs and meanings that inspire and legitimate the activities and campaigns of a social movement organisation' - are the mechanisms that assist activists and would-be activists in crystallizing their grievances. 
Northern Ireland. As people struggled for moral and cognitive frameworks to understand, assess, and sometimes resist the significant changes in their lives, ${ }^{5}$ memories of earlier successful resistance flourished. Events such as resistance to Home Rule in 1912 represented structures of meaning that that were constructed through a process of streamlining their representations and imagery. The excess of meaning that these structures carried made them potential triggers of mobilization, which provided power to the narratives that articulated them (Vélez-Vélez 2013: 56). Jackson (1992: 164) argues that the unionist rulers of Northern Ireland saw in the issues and personalities of 1912-1914 an important moral prop in the same way as varieties of nationalism have sought to cultivate the legacies of Wolfe Tone or Patrick Pearse.

A traumatic consequence of the past 35 years for the Protestant working class, however, has been its crisis of identity. Loyalist ideology is constructed so as to draw on class, community, sectarianism, and national identities. All these, however, are subordinate to the dominant representation of that ideology, the notion of 'Britishness' within the collective whole (McAuley 1994; Hall 1994; Nelson 1984; Novosel 2013). Rolston reinforces this point, arguing that the very variety of mural imagery in loyalist areas reflects the lack of political consensus, while playing a central role in the construction of community identity and ideals (Rolston 1992; Graham 1992). Movement leaders also commonly overlay different collective memories to unify divergent groups who often present a fragmentary list of demands (Farthing and Kohl 2013: 9-10). The mural discourse demonstrates the importance of past events to Protestant identity and the role of historical precedent in contemporary attitudes and decision-making. ${ }^{6}$ The events of 1912-1914 serve as a useful foundation or creation myth for unionists in Northern Ireland. In 1968, the Protestant Telegraph declared:

In 1912 Ulster was in the peculiar position whereby she would have had to oppose British troops in order that she, Ulster, might remain British. That day may come again [...] Our fathers had to arm themselves in defence of previous traitors in Westminster, and it seems as if history is going to

5 For Protestants in particular, these changes included the disbandment of the 'B-Specials' in 1969, the proroguing of Stormont in 1972, and the introduction of a power-sharing executive in 1974 .

6 Critical events in Protestant time include the 1641 Rebellion, the Siege of Derry in 1689 , the Battle of the Boyne in 1990, the defiance of Home Rule between 1912-1914, and 1 July 1916 when the $36^{\text {th }}$ (Ulster) Division was destroyed near Thiepval on the first day of the Battle of the Somme. 
repeat itself. Wilson and Lynch will not be dealing with weaklings like O'Neill when they come to deal with the hard core of Ulster Protestants. (Protestant Telegraph 1968)

The narrative behind the slogan 'We Are the People' is crucial in the shared identity of Protestants in Northern Ireland. Shirlow and McGovern (1997: 1) argue that whether it is written on the walls of Belfast, spoken by the Apprentice Boys of Derry, or sung at Windsor Park, the phrase 'We Are the People' is a clear and unequivocal statement of loyalty and devotion to and from the Protestant people of Ulster. As such, this adage is a grand signifier of loyalty, devotion, and identity. Declan McGonagle (2006: 114) remembered Protestant protesters in Northern Ireland shouting, 'We are the people' in the face of the emerging civil rights campaign of the late 1960 . The battle cry, in other words, represented a fundamental mind-set, a selfvalidating sense that was based on a myth of the way that things naturally and elementally are and must be. If anything, it is a constant reminder of a self-identified community who sense that they are besieged and threatened by sociopolitical and cultural oblivion. The slogan, therefore, fabricates notions of cultural solidarity and collective power. This foundation narrative became increasingly important among grass-roots unionism during the late 1960 s and 1970s, as the descent into violence created a crisis of confidence in this community.

The ways in which Protestant leaders exploited collective memories of Edward Carson and his resistance to Home Rule in 1912, and later the Ulster Workers' Council strike's success in bringing down the power-sharing government in 1974, highlight the ways collective memories can have a homogenizing effect, constructing a collective identity among activists and creating conditions for mobilization. The significance in examining the narratives is to highlight the dependence of these constructs with the mnemonic structures to convey and elicit meaning. For instance, the experience of resistance in 1912 and loyalty during the First World War as mnemonic structures are seen as giving meaning to the claim of resisting power-sharing in 1974. So as loyalists equated the resistance of Home Rule in 1912 with the ultimate tool of resisting any further erosion of Protestant identity through power-sharing, the recollections of the 1912 movement and involvement in the First World War as a collective memory are the ones that substantiate the claim as legitimate and significant.

The fiftieth anniversary of the opening of Stormont in 1971 was met by the signing of a pledge that was modelled on the Ulster Solemn League and Covenant (1912). The language of both is almost identical, with the 
1971 pledge committing the signatories: '[T]hroughout this our time of threatened calamity to stand by one another in defending our cherished position of citizenship in the United Kingdom and in using all lawful means to defeat any conspiracy to overthrow our Parliament'.

\section{Siege Mentalities and Protestant Working-Class Grievances}

While Protestant opinion perceived the civil rights as a Catholic movement, many working-class Protestants could identify with its demands. Resentment existed, however, that it seemed to only be addressing Catholics (as noted in interviews carried out by Ferguson and McAuley, in this volume).

Jackie Redpath, a community activist in the Protestant working-class Shankill area of Belfast in the 1970s, explained the sense of grievance felt by many Protestants at the time:

From a Protestant working class point of view, from a Protestant community point of view $[. .$.$] what was happening was the very quick stripping$ away of almost everything of what you had known as certainty [...] It felt like everything you had known was now up for grabs and everything you had known was being stripped away. And it stirred up that old sense, which was hundreds of years old, of being a community under siege [...] [The loss of Stormont and the increasingly deteriorating security situation meant] it was a time when your very identity was under question. There were no more certainties. (Redpath 2014)

While grievances were related to identity to a larger extent, they also had an economic dimension. By the time of the civil rights movement's agitation, Northern Ireland was an employment black spot within the United Kingdom. In 1984, for example, a year before demonstrations against the Anglo-Irish Agreement, almost 70 per cent of households in the Protestant Rathcoole estate in Newtonabbey were in receipt of state benefits, with those in work largely on very low incomes.

\section{The Mobilization of Workers: The Ulster Workers' Council Strike, 1974}

Protestants responded to the suspension of Stormont and the introduction of direct rule by Westminster in a number of ways. Even before this 
event, Protestants had begun to mobilize - the lack of confidence in the established authorities which was felt by grass-roots unionism, and particularly working-class loyalists, led to the emergence of new groups in several key areas. New political movements were formed, including a major new loyalist paramilitary organization, the Ulster Defence Association (UDA), organizations of industrial workers, the Loyalist Association of Workers, led by shipyard worker, Billy Hull, and Ulster Vanguard, led by Bill Craig (Gillespie 2004). Ian Paisley and his Democratic Unionist Party (DUP) also came to prominence in the late 196os and took centre stage in Protestant mobilization efforts in 1970s.

Ulster Vanguard was an attempt to re-create the anti-Home Rule alliance of politicians, physical force militants, and industrial workers in a threewing movement against various enemies of 'true loyalism' (Nelson 1984: 101). Vanguard focused its policies on a collective memory of Protestant privilege in the pre-1968 era. The policy of Vanguard related, in its entirety, to sovereignty in Northern Ireland and a return to the pre-1968 status quo. It was an expression of the Protestant 'siege mentality', couched in constitutional terms (Nelson 1984:101). Between February and March 1972, in reaction to British plans to remove internal security from Stormont's remit, Vanguard organized a number of progressively larger rallies. These culminated in a final demonstration in Belfast's Ormeau Park on 18 March with approximately 60,000 in attendance (although estimated at 92,000 by organizers). Drawing on the historical collective memory of Edward Carson and the founding of the Ulster Volunteer Force (UVF) in 1913, a noteworthy feature of the protests was the inspection of persons drawn up in ranks. A Home Affairs report noted that " $t$ ] his militaristic pose was more notable at the final Rally in Belfast where a guard of honour was formed by members of the U.S.C. association; the Colours of the old U.V.F were paraded; women in uniform type clothing were drawn up in ranks and a contingent from the Oldpark Defence Association paraded in dark glasses and desert-hats, etc.' (PRONI 1972). The Loyalist Association of Workers also connected the current situation in 1972 and historical collective memories of Carson in 1912 and the rebellion and massacres of 1641 . One of their pamphlets from March 1972 reflected:

Portadown certainly lived up to its reputation on Saturday last with thousands of its Loyalist citizens displaying their loyalty to VANGUARD, as their Fathers did to Carson. This is the action we expected from the loyal provincial town, and by quoting Col. Saunderson when Home Rule was suggested 50 years ago - 'It may pass the House of 
Commons but it won't pass Portadown'. So today the sons of the men 50 years ago say exactly that. NOT AN INCH! (Loyalist Association of Workers 1972)

The decision to suspend Stormont was also met by a two-day strike. Many thousands of Protestant workers stayed home from work, paralysing the region and bringing industry, commerce, and public services to an almost complete halt (Irish Times 1972). This show of popular discontent demonstrated the effectiveness of the strike and convinced loyalists of all shades that such tactics could be used again for political ends. The tactic was used again in February 1973 in reaction to the internment of two UDA members, the first loyalists to be interned, following a grenade attack on a Catholic works bus. This strike, however, did not appeal to the wider unionist community on account of its narrow grievance framing, and because the violence that accompanied it alienated many Protestants. Yet, both these instances showed unionists the political effectiveness of using the industrial might of Protestant workers in a national stoppage.

In May 1974, an assorted collection of Protestant industrial workers and paramilitaries succeeded in bringing down the power-sharing Northern Ireland Executive. The Ulster Workers' Council (UWC) strike was called in protest to the political and security situation in Northern Ireland and more particular at the proposals in the Sunningdale Agreement, which would have given the government of the Republic of Ireland a direct say in the running of the region. The strike lasted two weeks and succeeded in bringing down the power-sharing Northern Ireland Executive. For the two weeks of the strike, effective political power was in the hands, not of Westminster nor of elected Northern Irish politicians, but of factory workers and labourers (Nelson 1984: 155). Martin Dillon (1994) has commented that " $\mathrm{t}$ ]he modern rebellion of 1974 is one of the most significant - and intriguing - events of the last 25 years of conflict [...] It was an episode of complex political, social and military events [...] The rebellion, by a large section of the loyalist and Unionist community, is a landmark in the history of the period'.

In early April 1974, the magazine of the UDA, the Ulster Loyalist, alerted its readers to the existence of the Ulster Workers' Council. The Northern Ireland that the council would fight for, it was stressed, would be one free of privilege and discrimination and notice was served on politicians, 'whatever banner they operate under, that the workers are no longer tools to be used to forward their political ambitions but equal 
partners and that the future of Northern Ireland will no longer be decided behind closed doors between rival groups of politicians, each jockeying for the best advantage for himself and to hell with the workers' (Ulster Loyalist 1974). The group emerged from what Glenn Barr (2014) called an 'abysmal' lack of leadership in Protestant working-class communities, in an attempt to fill this void. Acutely aware of the success of miners in Britain in forcing industry down to a three-day working week by reducing electricity supplies, the UWC adopted this action as a tactic in their protest (Barr 2014).

The results and impact of the collective action in May 1974 had farreaching consequences for future action. 1974 became central to loyalist collective memory. It was remembered because it met two conditions: activists considered the event commemorable and it met the mnemonic capacity to create a commemorative vehicle (Armstrong and Crage 2006). Disruptive, violent, large-scale events are more likely to be viewed as newsworthy. Direct participation or perception that an event caused a change (for better or worse) in the fate of a group also enhances commemorability (Armstrong and Crage 2006).

\section{The Ghost of Carson and 1985}

While the strike may have ostensibly brought an end to the power-sharing executive, and so was seen as a victory for loyalists, Sarah Nelson (1976: 223) notes that the stoppage could not be seen as a 'victory for the working class' because the strike itself was not fundamentally about a class issue. Further, while some of those who were active in the constituent groups of the UWC joined the United Ulster Unionist Council and ran in elections for the Constitutional Convention in the aftermath of the fall of Sunningdale, thereby politicizing some of the gains made on the streets; the grass-roots movement itself dissipated in the months after the strike. Gillespie argues that in those months it became clear that the UWC as an organization hardly existed. It had, however, provided the glue which held together a disparate coalition of loyalist workers, politicians, and paramilitaries just long enough to force the collapse of the power-sharing executive (Gillespie 2004: 129-130). Meyer (2006: 202) also contends that the stories people hear about the past influence how they view future possibilities and, most significantly, their prospective role in making it. Thus, 1974 would be seen as a success by mobilizing forces in unionism and would be used in future. 
It would take a new confluence of events and grievances to establish the same momentum in order to lead to mass collective action again. As Andy Tyrie, chairman of the UDA remarked a couple of months after the strike:

Let's be honest about it. As far as the loyalist paramilitary organisations are concerned, they will never be the same again until there's a crisis situation. All we can do is hold on to a good nucleus of men and build and organise, and wait for the opportunity to ride the waves again. (Fortnight 1985)

In the weeks and months after the Anglo-Irish Agreement was signed on 15 November 1985 between Britain and the Republic of Ireland on what amounted to joint-sovereignty of Northern Ireland, there were two models which could be followed by leaders hoping to mobilize unionist reaction: the first was Edward Carson's leadership in 1912 against Home Rule; the second was the UWC strike of 1974. Both events had inspired many unionists to believe that loyalist mass mobilization, backed up by the threat of industrial disruption and physical force, would be enough to frustrate the plans of the British government (Focus Group 2014). Loyalist strategy sought a dramatic demonstration of community solidarity. At the same time, these two moments of popular Protestant activism were remembered as a golden age of resistance, and ones that should be emulated.

While the threat of strike on the same scale of 1974 was implied, loyalist leaders evoked 1912 and Carson to mobilize their supporters. One very clear connection between 1912 and 1985 was the establishment of 'Ulster Clubs'. The Ulster Clubs were set up by radical unionists in the rural areas of Northern Ireland after the signing of the Anglo-Irish Agreement in November 1985 . This was an attempt to provide both organization and muscle to the unionist campaign against the initiative. In their conscious mimicry of Carson's Ulster Clubs in the fight against Home Rule at the beginning of the twentieth century, they represented a classic instance of unionism's tendency to look back to past victories in order to deal with the present crises (Cochrane 1997: 86; McBride 2001).

Ulster Club spokesman, Alan Wright, commented: 'It is a case of history repeating itself. In 1893 when the first Home Rule Bill for Ireland was presented to Parliament, the Unionists got together and formed a Unionist Club. So we decided that we needed a structure that everyone could come together under' (Fortnight 1986). With a direct reference to Carson, Wright stated, '[we] need to have what Carson had which was a people's army to make this country totally ungovernable to bring this government to its 
knees'. But Wright also recognized the need to conjure the memory of 1974, and the role that ordinary, working-class Protestant mobilization played in the result:

Obviously comparisons are being made to '74. We have to recall that in February 1974 the politicians went back with a massive mandate to smash Sunningdale. But the politicians didn't smash Sunningdale. They started the momentum but the workers and the ordinary people reminded the government that it was still, very much loyalist fingers on all the buttons in this society [...] We see this Agreement as being the first half mile in the road to Dublin rule. And that is nauseating, repugnant and totally unacceptable. I believe you will see something even greater than 1974 . (Fortnight 1986).

The most obvious expression of loyalist opposition was the massive 'Ulster Says No!' rally in Belfast on 23 November 1985 , where the crowd was reported to be 100,000 (although unionists claimed 200,000). In his speech to the crowd, Ian Paisley directly quoted Carson: 'We ask for no privileges, but we are determined none shall have privilege over us'. While the links between collective memories and collective action seemed much stronger in 1985 than they were in 1974, mobilization of Protestants against the Anglo-Irish Agreement failed to reach the same level as that of Sunningdale. Leaders were unable to secure unified support on what action to take. The Belfast Telegraph, conducted a poll of Catholics and Protestants in January 1986 and noted that only 22 per cent of those surveyed were in agreement with taking industrial action against the agreement (though considerably stronger amongst the working-class), and 74 per cent disagreed (Belfast Telegraph 1986). ${ }^{7}$ Jackson (1992: 174) has suggested that the Unionist command has shown itself capable of occasionally mobilizing its resources; but it has also proved to be much less adept at coping with its own transient success and lacks the ability to supply coherent direction or a long-term flexible plan of campaign. This certainly seems to have been the case in 1985-1986. There are a number of reasons for this. Firstly, as outlined in Bosi and De Fazio (in this volume), scholars tend to underemphasize specific characteristics of mobilization, including the intra-movement competition and conflict within heterogeneous ethnonationalist groups. This appears to have been

7 Among the Protestants from the $\mathrm{C}_{2} \mathrm{DE}$ group who were surveyed, 37.1 per cent were in favour of taking industrial action in protest to the Agreement (compared to 25.9 per cent in the $\mathrm{ABC} 1$ group). 
the case in 1985 more so than in 1974. Those within the movement could not be considered a monolithic collective and there were divisions over what sort of action to take. A memo from J.E. McConnell of the Political Affairs Division of the Northern Ireland Office on the aftermath of the 'Day of Action' in March 1986 noted that: 'All the people who rang me [...] are deeply opposed to the Agreement but while they supported the strike, they are extremely concerned about the rejection of the Downing Street talks by their leaders [...] They now feel that Unionists in Northern Ireland are in an impossible position' (PRONI 1986). The collective identities constructed from historical myths by movement mobilizers around opposition to the Anglo-Irish Agreement are largely based on polarized identities that are found in deeply divided societies. When groups define themselves and each other in terms of the conflict, they collude in perpetuating the psychological bases for destructive conflict (Northrup 1992). Further, this zero-sum stance means that compromise becomes impossible and the protest is seen as ineffective when it does not achieve the aims it sets out to.

Also, while memories of particular transformative events, such as 1912, are produced and reproduced at times of political crises in unionism, which enhance the capacity of the community to mobilize, it can also constrain it. Benford (2002) argues that narrative and storytelling can act as a means of social control in social movements. This could be seen in two ways in the 1985 campaign. Firstly, the state used the idea of historically based narratives and collective identities to control the action that protesters took. It was noted in a memo that civil disobedience (non-payment of rent, rates, electricity, and water) could be used by unionists to oppose the Anglo-Irish Agreement. This was seen as one of the more problematic actions unionists could take because the arrangements for dealing with non-payment of such items would not cope with mass refusal. Ministers were, therefore, encouraged to 'emphasise traditional values of Protestant ethic to counter any pressure for such action' (PRONI 1985).

Secondly, there were divisions over the use of violence and this did not sit easily with constructions of identity based on the past. On reactions to the 'Day of Action' in March 1986, it was noted: 'The general feeling is one of revulsion against the behaviour of many of the strike supporters on Monday [...] There is no doubt that many supporters of the strike have been frightened at the ferocity of the action taken by the "hardmen"' (PRONI 1986).

Nonetheless, while the collective action was not sustained, nor did it achieve any meaningful political change envisaged by the protesters, it does demonstrate that collective memory played a significant role in mobilizing the masses, even if only for a short period of time. 


\section{Conclusion}

Collective memories help bring the past into the present, and create responsibilities to those who came before. These memories meet a number of needs and people are likely to turn to them when they are struggling to make sense of events in times of uncertainty. Collective memory links a sense of the past to present day injustices. In Northern Ireland, the social appropriation of collective memories, particularly historical memories, is extensively used by community leaders and politicians (McGrattan 2013). These pre-existing narratives and memories can be drawn upon by leaders to build lines of solidarity and/or forge strategies for collective action. Events are transformed into collective memories through the process of social appropriation. This process of social appropriation triggers collective action as actors use the event to construct action frames that signal favourable environmental conditions. Consequently the event is incorporated into a social group's memory repertoire. The capacity of mnemonic practices to provide meaning to current events in light of the past, and potentially directing future ones, brings about the quality of memory processes to engage audiences into action (Vélez-Vélez 2013: 61). This does not always have the desired effect, as is seen by the 1985 example. While the collective memory of Carson was once again re-appropriated to mobilize support, the support was limited, signalling that other factors are indeed necessary to sustain action, as well as suggesting that movement narratives can have a constraining effect, in tandem with a mobilizing one.

As Lee and Yang (2007) demonstrate, nostalgic and critical memory is not sufficient to bring about sufficient collective action. The emergence of labour unrest also depends on the local structure of economic and political opportunities and the organizational capacity of workers' communities. Nonetheless, because collective memories represent more than recollections of shared events and happenings, and also entail the prescription of symbolic events in relation to present (and future) ones, a focus on memory and collective action adds a meso level of analysis to social movement research. Ferguson and McAuley's research (in this volume) explores the role of collective identity among loyalists and the importance of narratives in its creation. They suggest that these narratives either perpetuate violence or can be reformulated to abandon political violence in a post-conflict society. This makes the process of collective memory and identity constructs in mobilizing communities even more worthy of consideration. 


\section{Works Cited}

Anderson, Don. 1994. Fourteen May Days: The Inside Story of the Loyalist Strike of 1974. Dublin: Gill and Macmillan.

Armstrong, Elizabeth, and Suzanna Crage. 2006. 'Movements and Memory: The Making of the Stonewall Myth'. American Sociological Review 71: 724-751.

Barr, Glenn. 2014. 'Strike leader Glenn Barr recounting events from 40 years ago (part 1)', available: https://audioboom.com/boos/2176343-uwc40-strike-leaderglenn-barr-recounting-events-from-40-years-ago-part-1 (Accessed 10 January 2015). 19 May.

Belfast Telegraph. 1986. Opinion Poll, 14 January. Northern Ireland Political Collection, Linen Hall Library.

Benford, Robert. 2002. 'Controlling Narratives and Narratives of Control within Social Movements'. In Stories of Change: Narrative and Social Movements, ed. Joseph E. Davis. Albany, NY: SUNY Press, 53-78

Bosi, Lorenzo. 2006. 'The Dynamics of Social Movement Development: Northern Ireland's Civil Rights Movement in the 1960s'. Mobilization 11.1: 81-100.

Bruce, Steve. 1994. The Edge of the Union: The Ulster Loyalist Political Vision. Oxford: Oxford University Press.

Campbell, Sarah. 2015. Gerry Fitt and the SDLP: 'In a Minority of One'. Manchester: Manchester University Press.

Cochrane, Fergal. 1997. Unionist Politics and the Politics of Unionism since the AngloIrish Agreement. Cork: Cork University Press.

Dillon, Martin. 1994. 'Foreword'. In Fourteen May Days: The Inside Story of the Loyalist Strike of 1974, by Don Anderson. Dublin: Gill and Macmillan, ix-xi.

Doerr, Nicole. 2014. 'Memory and Culture in Social Movements'. In Conceptualizing Culture in Social Movement Research, ed. Britta Baumgarten, Priska Daphi, and Peter Ullrich. London: Palgrave Macmillan, 206-226.

Edy, Jill. 2006. Troubled Past: News and the Collective Memory of Social Unrest. Philadelphia: Temple University Press.

Esman, Milton. 1994. Ethnic Politics. Ithaca, NY: Cornell University Press.

Eyerman, Ron. 2015. 'Social Movements and Memory'. In Routledge International Handbook of Memory Studies, ed. Anna Lisa Tota and Trever Hagen. London: Routledge, 79-83.

Eyerman, Ron, and Andrew Jamison. 1998. Music and Social Movements:Mobilizing Traditions in the Twentieth Century. Cambridge: Cambridge University Press.

Farthing, Linda, and Benjamin Kohl. 2013. 'Mobilizing Memory: Bolivia's Enduring Social Movements'. Social Movement Studies 12.4: 361-376.

Flesher Fominaya, Cristina. 2010. 'Collective Identity in Social Movements: Central Concepts and Debates'. Sociology Compass 4.6: 393-404. 
Focus Group. 2014. With Protestant members of trade unions, political groups and former paramilitaries. Sarah Campbell as facilitator. Belfast. 29 August.

Gamson, William A. 1992a. 'The Social Psychology of Collective Action'. In Frontiers in Social Movement Theory, ed. Aldon Morris and Carol McClurg Mueller. New Haven, CT: Yale University Press, 53-76.

Gamson, William A. 1992b. Talking Politics. Cambridge: Cambridge University Press.

Gillespie, Gordon. 2004. 'The Origins of the Ulster Workers' Council Strike: Structure and Tactics'. Études Irlandaises 29.1: 129-140.

Gillespie, Gordon. 2007. 'Sunningdale and the 1974 Ulster Workers' Council Strike'. HistoryIreland 15.3. http://www.historyireland.com/2oth-century-contemporaryhistory/sunningdale-and-the-1974-ulster-workers-council-strike/.

Gongaware, Timothy B. 2003. 'Collective Memories and Collective Identities: Maintaining Unity in Native American Educational Social Movements'. Journal of Contemporary Ethnography 32.5: 483-520.

Gongaware, T.B. 2010. 'Collective Memory Anchors: Collective Identity and Continuity in Social Movements.' Sociological Focus 43-3: 214-239.

Graham, Brian. 1992. 'Contested Images of Place among Protestants in Northern Ireland'. Political Geography 17.2: 129-144.

Halbwachs, Maurice. 1992. On Collective Memory. Chicago: University of Chicago Press.

Hall, Michael. 1994. Ulster's Protestant Working Class: A Community Exploration. Antrim: Island Publications.

Harris, Fredrick C. 2006. 'It Takes a Tragedy to Arouse Them: Collective Memory and Collective Action during the Civil Rights Movement'. Social Movement Studies 5.1: 19-43.

Irish Times. 1972. 'Two-day strike against suspension of Stormont'. Irish Times, 28 March.

Jackson, Alvin. 1992. 'Unionist Myths, 1912-1985'. Past and Present 136.1: 164-185.

Jasper, James M. 2014. 'Constructing Indignation: Anger Dynamics in Protest Movements'. Emotion Review 6.3: 208-213.

Kubal, Timothy, and Rene Becerra. 2014. 'Social Movements and Collective Memory'. Sociology Compass 8.6: 865-875.

Loyalist Association of Workers. 1972. Pamphlet, March.

Lee, Ching Kwan, and Guobin Yang, eds. 2007. Re-envisioning the Chinese Revolution: The Politics and Poetics of Collective Memories in Reform China. Stanford, CA: Stanford University Press.

McAuley, James W. 1994. The Politics of Identity: A Loyalist Community in Belfast. Aldershot: Avebury. 
McBride, Ian. (ed.) 2001. History and Memory in Modern Ireland. Cambridge: Cambridge University Press

McGonagle, Declan. 2006. 'Myths and Mind-sets, or How Can We Be Real?'. In Reimagining Ireland, ed. A.H. Wyndham. Charlottesville: University of Virginia Press.

McGrattan, Cillian. 2013. Memory, Politics and Identity: Haunted by History. Basingstoke: Palgrave Macmillan.

Melucci, Alberto. 1989b. 'The Symbolic Challenge of Contemporary Movements'. Social Research 52: 781-816

Meyer, David. 2006. 'Claiming Credit: Stories of Movement Influences as Outcomes'. Mobilization 11.3: 281-298.

Misztal, Barbara. 2003. Theories of Social Remembering. Maidenhead: Open University Press.

Nelson, Sarah. 1976. 'Developments in Protestant Working Class Politics'. Paper delivered at the Institute of Irish Studies, Queen's University Belfast, 10 February. Northern Ireland Political Collection, Linen Hall Library.

Nelson, Sarah. 1984. Ulster's Uncertain Defenders: Loyalists and the Northern Ireland Conflict. Belfast: Appletree Press.

Northrup, T.A. 1992. 'The collusion of enemies: Identity and conflict in Northern Ireland.' Program on the Analysis and Resolution of Conflict, Maxwell School of Citizenship and Public Affairs, Syracuse University.

Northern Ireland Political Collection, Linenhall Library. 1968. 'Extracts from Protestant Telegraph. Protestant Telegraph, 2 November.

Novosel, Tony. 2013. Northern Ireland's Lost Opportunity: The Frustrated Promise of Political Loyalism. London: Pluto Press.

Oberschall, Anthony. 1973. Social Conflict and SocialMovements. Englewood Cliffs, NJ: Prentice-Hall.

Ó Dochartaigh, Niall. 1997. From Civil Rights to Armalites: Derry and the Birth of the Irish Troubles. Cork: Cork University Press.

Polletta, Francesca, and James Jasper. 2001. 'Collective Identity and Social Movements'. Annual Review of Sociology 27.1: 283-305.

Prince, Simon. 2007. Northern Ireland's '68: Civil Rights, GlobalRevolt and the Origins of the Troubles. Dublin: Irish Academic Press.

PRONI. 1972. 'Ulster Unionist Vanguard', 23 March. HA/32/5/10, Public Record Office of Northern Ireland.

PRONI. 1985. 'Anglo-Irish Agreement: Unionist Reactions', 22 November. CENT/3/25A, Public Record Office of Northern Ireland.

PRONI. 1986. 'Day of Action: Aftermath', 5 March. CENT/1/15/47A, Public Record Office of Northern Ireland.

Purdie, Bob. 1990. Politics in the Street: The Origins of the Civil Rights Movement in Northern Ireland. Belfast: Blackstaff Press. 
Redpath, Jackie. 2014. '40 Years On: The strike that brought down Sunningdale', Queen's University Belfast. Available at: https://audioboom.com/boos/2177442uwc40-panel-of-civilians-henry-sinnerton-jackie-redpath-nell-mccafferty (Accessed 10 January 2015). 19 May.

Rolston, Bill. 1992. Drawing Support: Murals in the North of Ireland. Belfast: Beyond the Pale.

Saleh, Alam. 2013. 'Relative Deprivation Theory, Nationalism, Ethnicity, and Identity Conflicts'. Geopolitics Quarterly 8.4: 156-174.

Shirlow, Peter, and Mark McGovern, eds. 1997. Who Are the People? Unionism, Protestantism and Loyalism in Northern Ireland. London: Pluto Press.

Smithey, Lee. 2012. 'Conflict Transformation, Cultural Innovation and Loyalist Identity in Northern Ireland'. In Culture and Belonging in Divided Societies: Contestation and Symbolic Landscapes, ed. Marc Howard Ross. Philadelphia: University of Pennsylvania Press, 85-106.

Snow, David A., and Robert Benford. 1992. 'Master Frames and Cycles of Protest'. In Frontiers in Social Movement Theory, ed. Aldon D. Morris and Carol McClurg Mueller. New Haven, CT: Yale University Press, 133-155.

Tilly, Charles. 1994. 'Afterword: Political Memories in Space and Time'. In Remapping Memory: The Politics of TimeSpace, ed. Jonathan Boyarin. Minneapolis: University of Minneapolis Press, 241-256.

Ulster Loyalist. 1974. 'The formation of the Ulster Workers Council'. Ulster Loyalist, 28 March.

Ulster Solemn League and Covenant. 1912. 'In Defence of Northern Ireland'. Box on Loyalist Ephemera, Northern Ireland Political Collection (NIPC), Linen Hall Library.

Van Stekelenburg, Jacquelien, and Bert Klandermans. 2013. 'The Social Psychology of Protest'. Current Sociology 61.5-6: 886-905.

Vélez-Vélez, Roberto. 2013. 'Moving memories in Vieques: Towards a memory approach in mobilization research.' International Journal of Liberal Arts and Social Science 1.2: 53-66.

Zamponi, Lorenzo. 2013. 'Collective Memory and Social Movements'. In The WileyBlackwell Encyclopedia of Social and Political Movements, ed. David A. Snow et al. Chichester: Wiley-Blackwell, DOI: 10.1002/9780470674871.wbespmo40 


\title{
6 Ulster Loyalist Accounts of Armed Mobilization, Demobilization, and Decommissioning
}

\author{
Neil Ferguson and James W. McAuley
}

\begin{abstract}
A section of the population here tried to overthrow the state by force of arms, and the British government, after the fall of Stormont, failed in their fundamental right, or the fundamental thing for them was to protect life and to me they failed in that. I could have easily got involved with the RUC, because, I mean, I wasn't involved in any criminal activity before I joined the Ulster Volunteer Force, but I felt that we had been let down by our government, who had handcuffed the security forces with their policy of appeasement and restraint rather than the same sort of policy they used in the conflict in the Falklands. If they had had the same attitude towards republicans, I don't think it would have been a war. I think it would have been a conflict that could have been put down in a couple of years. (Interview with UVF Volunteer, Belfast, Ferguson 2007)
\end{abstract}

This quote is from a former member of the Ulster Volunteer Force (UVF) and former prisoner who served thirteen years of a life sentence for murdering a republican paramilitary and who is now actively involved in conflict transformation, reflecting on why he decided to join the UVF during the 1970s. It is a quote that resonates with many of the accounts given by former loyalist paramilitaries about their reasons for shunning the 'legitimate' state forces in an attempt to combat violent militant Irish republicanism. This chapter will explore narratives shared by former loyalist paramilitaries which explored their participation in armed loyalist movements and actions, and how the paramilitary ceasefires and peace process facilitated their disengagement from politically motivated violence and their transfer into more civic or political roles within their community. These narratives were collected in a series of interviews conducted by both authors and their respective research teams over a decade from 2000 to 2010.

The fragmented response of loyalism ${ }^{1}$ gave rise to a multitude of paramilitary organizations, based in the Protestant working class. As the response

1 See Campbell (in this volume) for an extended discussion of working class loyalist mobilization and the collective memories which fuelled loyalist responses in the early 1970s. 
began to become more structured, two main paramilitary organizations dominated, one was the Ulster Defence Association/Ulster Young Militants grouping; the other was the UVF/Red Hand Commando grouping. The Ulster Defence Association (UDA) founded in 1971 grew out of the wide network of vigilante groups that had appeared in loyalist districts and the UVF, which (although it had surfaced in 1966) began to organize and recruit heavily in the early 1970s. The dynamic behind growing paramilitary membership continued to draw on existing notions, especially narratives of siege and community defence. It also gave expression to the conviction felt by many Protestants that the constitutional position of Northern Ireland was under direct threat, that the government response was weak, and that Northern Ireland faced a challenge that was not being effectively met by state forces, which were unable or unwilling to effectively engage militant republicanism. It must also be remembered that the motivations for young Protestants joining one armed grouping over another are complex and will vary across location and time depending on the legitimacy, popularity, and strength of the organizations in that locality and the current threats the community faced. Indeed in the tightly knit communities of Belfast, living in one particular street instead of the one around the corner may be the only significant factor in choosing to join the Red Hand Commando (RHC) over the UVF or the UDA. Furthermore, even the coherence of the UDA and the UVF as singular organizations is questionable, and at times battalions or brigades move in contradictory directions to the overall organization (McAuley 1994).

In line with Bosi and De Fazio (in this volume) and Fillieule (2010, 2015), the narrative accounts of mobilization and disengagement presented here are broadly supportive of the wider literature surrounding engagement in political protest, viewing social mobilization as a dynamic process involving individual agency and interaction between political actors, groups, and the context in fuelling engagement and disengagement in political protest and violence. As the narratives will demonstrate, any analysis of the paths in and out of armed groups must incorporate the repeated interplay between micro, meso, and macro factors as demonstrated in recent research with the Irish Republican Army (IRA) and the Italian Red Brigades (Bosi and Della Porta 2012), rather than relying on static grand macro theories (Fillieule 2015).

These narratives accounts explain how people sustain political protest (see Van Stekelenburg and Klandermans 2007, 2013) and the role of political socialization in that process (McLeod and Shah 2009; Petrovic, Van Stekelenburg and Klandermans 2014). In particular, these narrative 
accounts share much with the work of Klandermans and his colleagues (1997, 2003; Van Stekelenburg and Klandermans 2007) and illustrate the importance of social identity and shared emotion in the interviewees' personal understanding of their engagement in politically motivated violence. In terms of political socialization, the narrative accounts illustrate that while the political socialization is a lifelong process, with movement into conflict transformation after the ceasefires of 1994 and the Good Friday Agreement testament to this, late adolescence and early adulthood is the key period for the political socialization of the former paramilitaries, as it is with many people who engage in protest or join social movements in other contexts (Ferguson, Burgess, and Hollywood 2008; McLeod and Shah 2009; Silke 2003). For all our interviewees it was during this period of their lives that they decided to join loyalist paramilitary groups.

The individuals providing these accounts of mobilization into loyalist groups share similarities; they all came from urban working-class backgrounds. Indeed many of the interviewees reflected on how their living conditions and socio-economic opportunities were similar to the Catholics who were agitating for civil rights.

The questions that we have to ask, like when you look at civil rights, the people living in Brown Square and the Shankill were living in the same type of accommodation, the same type of conditions as the people in the Falls. There was no difference. They all had outside toilets. They all lived twelve to fourteen to a two-bedroomed house. So, I mean, what was the difference? (Interview with UVF Volunteer, Belfast, Ferguson 2007)

One of the key differences from their Catholic neighbours was that they had been socialized in the working-class loyalist traditions of band parades and Eleventh Night bonfires, while many had family members who had been in the Orange Order or who had attended political rallies organized by Protestant demagogues such as Ian Paisley:

There was a very strong community spirit, very loyalist, very unionist, very Orange. My father would have been in the Orange Order, I grew up in the junior Orange Order, you know, as you do. Follow in the family and community traditions [...] I suppose you didn't think you were sectarian. You weren't even aware of it. You weren't aware of being a bigot or anything like that. It was just your traditions you grew up with. (Interview with RHC Volunteer, Belfast, Ferguson 2007) 
Many of the loyalists we interviewed spoke of how they viewed Ian Paisley as a role model or looked up to him, or were naïve enough to believe in his 'black and white' rhetoric which fuelled their fears and pushed them towards loyalist paramilitary groups: 'I thought Ian Paisley was God. I thought whatever he said had to be true because he was a leader and he wore a collar and everything like that' (Interview with Ferguson 2004). While Paisley's role in recruiting young men into paramilitary groups was fiercely contested by himself and others (Taylor 1999; Tonge et al. 2014), he had a number of associations with members of paramilitary groups throughout his career and was involved in the creation of a number of quasi-paramilitary groups with links to members of the UVF and UDA, such as the Ulster Protestant Volunteers (UPV) in the 1960s, along with 'Third Force' and 'Ulster Resistance' in the 1980s.

However, Paisley had no proven involvement with the instigation of violence and he always stated that he never advocated the use of violence. Regardless of his role in these groups, his powerful speeches resonated with the fears of Ulster Protestants that they were being 'sold out' by Westminster and their lives and livelihoods were under threat from Irish Catholics and republicans. His messages and status as a 'man of God' had a profound influence on many working-class Protestants, an influence which caused many to consider using violence to defend Ulster and pushed some of them towards paramilitarism.

While these young paramilitary recruits had strong Protestant, unionist, loyalist (PUL) identities, were closely bound to their community, and had their fears amplified by Paisley and others, their political ideas were naïve and relatively unformed when they joined loyalist paramilitary groups:

I didn't see us as setting out to achieve anything. I saw us more as a reaction, as a deterrent. I always hoped that the IRA would desist from what they were doing and then the UVF would be able to reciprocate, which I'm hoping is happening now, albeit a long time later. At that time [the early 1970s] I don't think anybody my age would have thought we'd be going into thirty years of conflict. (Interview with UVF Volunteer, Belfast, Ferguson 2004)

At a time when governments, academia, and the media are focused on radicalization and the role of radicalization in leading to engagement in political violence, it is important to remember that many purveyors of politically motivated violence are not radical or have not been radicalized 
(Della Porta and La Free 2012). Many are politically and ideologically naïve, and their violence is the result of the more implicit pressures of group solidarity and/or explicit threats or feelings of threat than political intention (Fillieule 2015).

The interviewees were all young men living in a time of huge flux at the beginning of the 1970s and this offered lots of opportunity for adventure and risky behaviour, which provided novelty and excitement and led to some of them joining the Young Citizen Volunteers (YVC) or Ulster Young Militants (UYM) while most engaged in rioting and clashes with the neighbouring Catholic community or the security forces.

At the age of eleven I can remember listening to gun battles between the $B$ Specials and the IRA. So my earliest memory of some of the Troubles is that, coz at the bottom of the street was a wee off-licence or wee bar that used to be there called - and bullet holes riddled it the next morning. I was a child so it was a bit of excitement [...] From that age then until I think about sixteen or something I remember being involved in the riots. I laugh when I tell people [that] we were the first ones to be stoning the British troops. I think it was the Fusiliers or the Welsh Fusiliers. I can remember as clear them coming round on their wee jeep with none of this armour stuff that you have today, and it was a new experience for everybody, I think. It was certainly a new experience for a teenager. (Interview with UVF Volunteer, Belfast, Ferguson 2008)

Prior research within Northern Ireland and in other contexts has shown that eventual membership of armed political groups is the result of an incremental process of increasing acts of insurgence (Burgess, Ferguson, and Hollywood 2005; Ferguson, Burgess and Hollywood 2008; Oberschall 2004). The following is an example of such views:

There was a number [of reasons for joining a loyalist paramilitary group], the main one was one of my best friend's father was shot dead. He was a UDR [Ulster Defence Regiment] man. His young sister was eleven years old. She was shot in the legs. My hometown had been completely destroyed by IRA bombs twice. There were four or five other UDR men in the area who were shot. There was a couple of British soldiers that had been shot dead in Lurgan outside the hospital. A couple of local policemen [were] shot in the town. So, just that whole environment at that time. I went to the funeral of my friend's father. His young sister was screaming for her daddy to come back. I can remember crying. I left that, but swore 
[that] if I ever get the chance for revenge then I would [take it], so it was mostly a human response to what was happening around me. (Interview with UVF Volunteer, mid-Ulster, McAuley 2007)

Many of our interviewees discussed how they would begin on the fringes of the conflict, perhaps running with gangs and getting involved in riots, before being approached by, or approaching armed groups and becoming involved in assassinations or bombings. Even when they engage in their initial political activity, protest, or violence it is usually as the result of local-level reactions to the events taking place around them and is without any coherent or developed political strategy - it is a simple reaction to the perceived unjust action of others. As mentioned earlier, much of this initial activity is born from a frustration with the inability of the state to contain or counter republican violence, again reiterated here by another former UVF volunteer:

We wanted to smash back or hit back, and living in that area was a perfect place to do it. So that was how I became involved. It's yes I wanted to defend my area, yes I wanted to smash back at those who were creating the mayhem and the havoc and [I] genuinely and honestly felt that the police weren't doing enough, you know, they weren't defending us. (Interview with UVF Volunteer, Belfast, Ferguson 2008)

It is important to identify the necessary context for constructing loyalist identity, the role of community within that identity, and the place of a self-contained social system, which provides a coherence of meaning within loyalism. Feelings of grievance, frustration, and perceived injustice are common factors which promote movement participation (Klandermans 1997; Van Stekelenburg and Klandermans 2013), especially when these feelings are based on group-level comparisons which induce feelings of fraternalistic deprivation (Runciman 1966) and which also resonate with personal experiences (Foster and Matheson 1999). For many of our interviewees, this movement from an apolitical life into active political participation was the result of some incident that had a dramatic impact on their world view. Most of these critical events related to someone they knew being harmed or killed, or that the violence of the Troubles was 'getting a bit near to home'. In the words of a former loyalist paramilitary, membership in paramilitary groups 'was an explosion waiting to happen and it happened when I was fourteen, and by the time I was nineteen I had made a conscious decision to join the UVF. Not before that.' This interviewee had heard that a young 
man killed by one of 22 bomb explosions on 'Bloody Friday' in July 1972 shared the same name and age as himself. The effect this incident had on him was dramatic: 'And I thought, 'That's my fence sitting days over', and I joined the UVF. And there's so many stories like that where you talk to republicans and loyalists and you find out there was a moment. There was a moment when they crossed the Rubicon' (Interview with UVF Volunteer, Belfast, Ferguson 2004).

An unplanned and unpredictable occurrence or a critical incident, such as the Bloody Friday bombings, increases a person's chances of political mobilization by impacting on them in two distinct ways. Firstly, an individual's sense of collective identity is heightened as ethnocentrism increases as a reaction to the increased threat facing his or her community. Second, the critical incident precipitates a period of self-reflection that helps the individual to determine a boundary demarking acceptable and unacceptable expectations, treatment, and/or conditions. As with other interviewees, experiencing this critical event caused him to re-evaluate his life and the outcome was his decision to 'return the serve'. He began to engage in a campaign of violence against Irish republicans and the wider Catholic community, which led to his incarceration in HMP Maze for over half a decade.

During this period of self-reflection, the individual weighs up their 'resources', efficacy, social capital, and options for action and inaction, bringing in personal history, current circumstances, socialization experiences, socio-economic considerations, education experiences and prospects, sociopolitical context, etc., together as they try to make sense of the incident and create a future path for themselves. A number of scholars, including the philosopher Karl Jaspers (1970), have recognized the importance of the Grenzsituation (boundary situation) created by having to deal with a situation that prior knowledge or rational objective reasoning cannot prepare a person to overcome. These boundary situations or critical life events then force people to radically reconsider and reformulate their life trajectory. These boundary situations also demonstrate the dynamic linkage between macro-, meso-, and micro-level events interacting and producing the conditions for an individual to facilitate engagement in political violence and are common in other accounts of micro-mobilization in activist careers, criminal life histories, and engagement with terror groups (Fillieule 2015; Goodey 2000; Horgan 2014).

Interestingly, these young, politically naïve men are now engaged in politically motivated violence and actively engaged in committing murder or attempting to kill. Research has demonstrated that engaging in these 
activities has significant negative implications for psychological and physical wellbeing and personal freedom (Burgess, Ferguson, and Hollywood 2007; Ferguson, Burgess, and Hollywood 2010, 2015; Grossman 1996; Jamieson, Shirlow, and Grounds 2010), yet while mobilized they are not politically or ideologically radicalized. In becoming 'radicalized' we mean they enter a process of political and ideological awakening and develop deeper political understanding, ideals, and aspirations. For our sample, their political education or radicalization did not begin until they were imprisoned.

The prison years had a profound impact on their political life, with their protests continuing in prison, but now focused on the prison regime; in these encounters they also honed their negotiation and communication skills, which would assist them in their political careers post-incarceration. Prison also offered them the opportunity to develop their political thinking and engage in prison education programmes; indeed, for many of the loyalists incarcerated, prison provided their first real attempt at education. The 'opportunities' prison provided began to fuel this process of political and ideological radicalization (McAuley 2000, 2001). These developments are succinctly expressed by a former UVF volunteer:

I've been involved for something like 35 years and the next stage obviously when you get involved in the conflict, the more operations you carry out, the more you get involved, the bigger chance you've got of getting caught or killed. So I was caught, and put in prison, so I had those prison years where, and it should be no surprise to anybody, because some of the best leaders in the world developed their political thinking in prisons, Nelson Mandela [...] so it should come as no surprise that people in prison do develop because you've been removed from the conflict. (Interview with Ferguson UVF Volunteer, Belfast, 2006)

It is also clear that these prison years provided the space to think, which prompted these loyalist prisoners to reformulate their ideas and see the conflict from a fresh perspective while also developing a longer-term political strategy, that was only possible to develop in isolation from the action-reaction cycle of sectarian violence taking place on the streets of Belfast and elsewhere. Once released they found their thinking had moved forward and they were on a different page, in comparison to those continuing the conflict outside the prison walls. As another interviewee observed:

Prison just gives you an opportunity to be detached from the conflict. It's a dubious way to be detached, but you're detached from it and it 
gives you time to think. You come out with pretty clear ideas in your head. It's pretty difficult after that period of time when you're away and you go back and see your friends and colleagues from before and some of them are thinking in exactly the same way as they did in the early seventies. How's this happening like? And then they think because you've been in prison it's softened you or broken you or whatever, but that's not the case. It's just common sense, pragmatism. You can't go on killing each other forever. Some time you're going to have to talk, so why not do it now rather than go through another ten, twenty (or whatever) years of conflict? (Interview with UVF Volunteer, Belfast, Ferguson 2006)

So this reformulation and a renewed focus on education prepared them to leave prison ready for the next stage of their political journey, a stage which was exemplified by a move away from the employment of violence to a desire to engage with their local community to create the conditions for community development and conflict transformation. For most of the former loyalist combatants interviewed, one of the key reasons they began to disengage from political violence after the paramilitary ceasefires in 1994, was the desire not to witness another generation of children have the same experiences of political violence they had endured: 'Hopefully my kids will never see trouble like I seen. No never in my life do I want them to see that. I have a wee lad there and another child on the way' (Interview with UVF Volunteer, Belfast, Ferguson 2007). While social movement research and research from terrorism studies provide well-developed theoretical frameworks to explain mobilization into political movements, research on the processes involved in leaving social movements or disengaging from terrorist activities is much more limited (Ferguson 2011; Fillieule 2015; Horgan 2009; Klandermans 2003).

However, recent research on loyalist paramilitaries (Ferguson, Burgess, and Hollywood 2015), republican paramilitaries and members of the Italian Red Brigades (Bosi and Della Porta 2012), and with other armed groups from across the globe, such as Al-Qaeda-affiliated groups (Horgan 2009; Rashwan 2009; Vidino 2011), Euskadi Ta Askatasuna (ETA) (Reinares 2011), or neo-Nazi groups (Blee 2002; Bjorgo 2009), illustrate that a range of push-and-pull factors (e.g. losing faith in group ideology, burn out, change of circumstances, etc.) are involved in promoting or hindering an individual's demobilization from armed political groups.

Across the globe disarmament, demobilization, and reintegration (DDR) processes have become a common and critical aspect of post-conflict 
reconstruction initiatives (Knight 2008), with the reintegration of combatants into productive civilian life viewed as key to post-conflict security and recovery. Kingma (2000) provides four important reasons for engaging in DDR, namely, humanitarianism - many combatants are victims of the conflict in addition to being perpetrators of violence; compensatory justice - soldiers have done their duty and expect compensation because of their potential contribution - ex-combatants can be a major force in rebuilding war-torn societies; and finally, they are potential 'spoilers' who can jeopardize the peace process or engage in criminal activities which threaten economic and democratic stability and thus need to be dealt with.

However, there is no singular DDR programme and some approaches have been much more successful than others. One common measure of success is simply to count the numbers of combatants successfully demobilized, but there is a need to look beyond the numbers to explore the success of the reintegration of combatants into civilian society and this becomes much more difficult. Particularly when researchers try to understand the micro- or individual-level determinants of successful demobilization and reintegration. ${ }^{2}$ So while the consensus is that these processes are fundamental to building peace, increasing security and assisting in economic post-conflict recovery (Doyle and Sambanis 200o), their complex nature makes it difficult to distinguish which strategy or intervention makes what specific beneficial contribution (Humphreys and Weinstein 2007).

However, as in the case with every political conflict across the globe, Northern Ireland is a unique situation in terms of conflict transformation, DDR, and the lessons which can be learned and exported (Ferguson 2010; Rolston 2007; Shirlow and McEvoy 2008). Thus, all potential lessons need to be carefully considered before application elsewhere. Just as with any analysis of mobilization, any analysis of demobilization and disengagement must be a multilevel analysis which considers the interactions between the micro, meso and macro. In this context, any individual demobilization narrative from a loyalist paramilitary needs to be understood against the backdrop of a wider organizational disarmament process which began in 1998 and concluded in 2009 for the UVF and RHC and 2010 for the UDA, which were also part of the wider Northern Irish peace process.

For our interviewees the key drivers for demobilization came from within the organizations, rather than necessarily from within themselves. In particular, the leadership and the ability of the leadership to 'turn the tanker' and guide the rank-and-file membership towards a less militarized 
and more civilianized role was key to them disengaging from politically motivated violence:

I've seen people at the top and it's starting to filter slowly, slowly, slowly. A lot of stuff now going on is the foot soldiers, the ceasefire soldiers [...] and I know there are these thoughts within organizations, how do we address these kids? How do we basically get rid of them, you know what I mean, without them falling into ruin the way the LVF [Loyalist Volunteer Force] went, you know. (Interview with UVF Volunteer, Belfast, Ferguson 2008)

However, guiding the membership towards a new violence- and crime-free future is not as easy as many outsider observers, or loyalist leaders would like it to be. In particular, the paramilitaries fear that the peace process would make them 'redundant' and negatively impact on their ability to finance themselves. Or that this inactivity and lack of direction would in turn lead to the development of schisms within the organizations, such as that witnessed in the 1996 with the birth of the LVF, or the degeneration of different companies into organized crime gangs:

At this point in time, the paramilitaries are disintegrating or mutating into gangs because it's, since 1994 when the ceasefire was called, it's what do you do now mate, we're redundant aren't we? [...] How do paramilitaries justify their existence if there's no conflict? Yes, we've tried to move and alter culture, trying to get people involved in the community, trying to get people involved in politics and some people just want to be by themselves, so we do try. But the greed, the money, I mean you're talking about big money. (Interview with UVF Volunteer, Belfast, Ferguson 2007)

While the role of the loyalist leadership in providing direction was often praised by the former loyalist paramilitaries, the leadership, or, more precisely, the lack of leadership and strategic direction within loyalism was viewed as a barrier to demobilization by former combatants. Generally, the barriers discussed usually related to the lack of capable leadership within loyalism and unionism more broadly or the lack of a grand political project within loyalism. The lack of a long-term political project was very much related to the nature of loyalism being focused on maintaining the status quo or simply combating the IRA, without any grand goal, such as achieving a united Ireland, to rally the troops around. The interviewees also tended to make comparisons with Sinn Féin and the Provisional IRA and bemoan how Sinn Féin and the IRA were better placed to provide opportunities to 
their volunteers post-agreement than loyalism could. This former loyalist paramilitary sums up these problems:

The educated, your articulate, you never got them in loyalist paramilitaries. I mean, that was one thing that there was a major, major shortage of. You had nobody to speak, to formulate policy, to talk about strategy, to talk about the way forward. It didn't exist. You had one or two thinkers, but not in the same degree as you would have had within the republican circles, so it was more or less a blind man fumbling in the dark. Where do we go from here and how do we go from here? How can we be used? (Interview with UVF Volunteer, Belfast, Ferguson 2008)

It is also important to note that while these former paramilitarists began their journey into these political movements from a start position of political naivety and only became politically educated and radicalized through their lengthy involvement or during imprisonment, when they disengaged from politically motivated violence they did not become de-radicalized or disengaged from political activity.

Since the ceasefires many former Northern Irish paramilitaries became involved in community and youth work as a form of community capacitybuilding or conflict transformation (Mika 2006), and likewise, the majority of our interviewees were now working on a variety of projects, such as, truth recovery and storytelling, co-ordinating restorative justice programmes, setting up mobile phone contacts to diffuse interface tension, developing sports and community activities, promoting racial tolerance, and/or were involved in local politics.

Thus, we have a paradox that while the political agency of the participants fuelled decades of conflict and political violence; violence that has left peace process of Northern Ireland stagnating under the shadow of the Troubles, yet it means they are also uniquely placed to initiate the attitudinal and behavioural changes necessary to persuade the younger generations not to continue the cycle of violence. Former political prisoners have been able to work together across community boundaries in a way that is less apparent among mainstream political parties (McAuley 2002; Shirlow and McEvoy 2008).

Indeed, the leadership shown by former prisoners has been instrumental in preventing the resumption of organized political and communal violence across Northern Ireland rather than successful policing or elite political accommodations (Shirlow et al. 2005; Shirlow et al. 2010). This point is clearly articulated by one of the former loyalist prisoners we interviewed: 
If anybody thinks that the PSNI [Police Service of Northern Ireland] are maintaining the peace in the interfaces, they are living in cloud cuckoo land. The paramilitaries are maintaining the peace at the interfaces. But that's good news. Some people would say, 'That's terrible - it shows the power they have', but given the year we had last year, and the year before that, and the year before that, and the year before that, it's not bad that we have this degree of calm at this point in time. (Interview with UVF Volunteer, Belfast, Ferguson 2007)

For the vast majority of our participants, their political lives were now focused on using non-violent means to bring future political changes. So while the participants were politically naïve when their journeys begin in the early days of the Troubles, after 30 years or more of being politically active their journey continues, yet for many the direction of their journey has changed to match the wider changes in Northern Irish society, however, their political identity and radical beliefs have not waned.

For the interviewees there was also a realization that to have a 'normal' peaceful society there would be a need for former combatants to become reintegrated into mainstream society and shake off the labels and associated stigma attached to being an 'ex-prisoner' or 'former paramilitary'.

I've got to a position, which you know it is a position within the community, doing a lot of work the schools recognize, the police recognize, loads of things. I've dropped the tag of ex-prisoner and all that stuff, dropped that a long time ago. You know, some people feel that they still need to use that and we were saying, people like [David] Ervine ${ }^{3}$ were saying, like there has to come a stage where you leave that behind [...] you have to move beyond that and move forward. (Interview with UVF Volunteer, Belfast, Ferguson 2008)

However, many have found this difficult especially as they felt rejected by mainstream society and the political elite; which tended to blame them solely for the Troubles:

As someone who has worked towards trying to create a transition I realize all the difficulties involved in that and that again creates resentment [...]

3 David Ervine was a UVF member and former prisoner who became leader of the Progressive Unionist Party (PUP) and was elected to the Northern Irish Assembly. For a detailed biography, see Moloney (2010) or Sinnerton (2003). 
when you realize how tirelessly a lot of people worked to try and make that happen these people [middle-class unionists] have really simplistic views of the way things work. You just don't wind down thirty years of militarism and paramilitarism just like that. You can't turn it off. (Interview with UVF Volunteer, Belfast, Ferguson 2008)

During the interviews it was clear the narratives were still being written and many were still active in politics, while for others the war was over and it was time to move on and give time back to their families and/or communities as a means of reparation for the time spent in prison. This enduring politicization should not be surprising as research in other settings has clearly demonstrated that while collective action is contingent on holding a strong collective identity (Huddy 2001) once people are spurred into action, it is difficult to simply switch it off (Van Stekelenburg and Klandermans 2007).

It is clear that the accounts provided here demonstrate the dynamic role of identity in collective action, and how, while the introduction of a peace accord and the resultant societal change are powerful, they may not cause individuals to de-radicalize and de-politicize and simply reintegrate into the masses. Instead, we see continued radicalization and a strong attachment to collective identity - just channelled into a new direction more fitting with the new sociopolitical context.

Part of this process will also involve cognitive dissonance (Festinger 1957). In that, once people make a decision to follow a particular course of action, they have to create justifications for pursuing this course. So the more behavioural commitment to the group and group goals, the stronger the feelings and cognitive justifications for this behaviour and the more likely they will continue their activism in spite of the costs. As McCauley and Moskalenko (2008) illustrate, the activist is likely to feel more pride in group success and more anger and humiliation with group failure as they rationalize and defend their actions and devise reasons to rationalize and explain their behaviour.

\section{Conclusion}

Mobilization into loyalist paramilitary groups during the Troubles in Northern Ireland shares much in common with social movement theories and research with other protest groups from Europe and beyond. In particular, these narratives bear a remarkable resemblance to the narratives provided 
by the IRA and Red Brigade volunteers interviewed by Bosi and Della Porta (2012), especially with the participants who followed the 'instrumental' and 'solidaristic' paths into these groups. These narrative accounts of mobilization, engagement in political action, and the processes involved in disengagement from politically motivated violence illustrate the complex range of factors which require consideration in order to understand the drivers pushing individuals in and out of these social movements. It must also be noted the majority of the participants in this study joined the UVF, UDA, or RHC in first decade of the Troubles, thus their experiences and motivations will differ from more recent recruits, and especially from those who joined after the 1994 ceasefire. Future research with a variety of ideologically different violent and non-violent groups from across the globe, who maybe are still actively engaged or have perhaps disengaging or even disbanded, will allow theory to develop and provide researchers and policymakers with an improved means of conceptualizing the scale and intricacy of mobilization and demobilization processes.

\section{Interviews}

Conducted by Ferguson, Belfast, 2004

Conducted by Ferguson, Belfast, 2006

Conducted by Ferguson, Belfast, 2007

Conducted by Ferguson, Belfast, 2008

Conducted by McAuley, mid-Ulster, 2007

\section{Works Cited}

Blee, Kathleen, M. 2002. Inside Organized Racism: Women in the Hate Movement. Berkeley: University of California Press.

Bjorgo, Tore. 2009. 'Processes of Disengagement from Violent Groups of the Extreme Right'. Leaving Terrorism Behind: Individual and Collective Disengagement, ed. Tore Bjorgo and John Horgan. London: Routledge, 30-48.

Bosi, Lorenzo, and Donatella della Porta. 2012. 'Micro-mobilization into Armed Groups: The Ideological, Instrumental and Solidaristic Paths'. Qualitative Sociology $35: 361-383$.

Burgess, Mark, Neil Ferguson, and Ian Hollywood. 2005. 'Violence Begets Violence: Drawing Ordinary Civilians into the Cycle of Military Intervention and Violent Resistance'. Australasian Journal of Human Security 1: 41-52. 
Burgess, Mark, Neil Ferguson, and Ian Hollywood. 2007. 'Rebels' Perspectives of the Legacy of Past Violence and of the Current Peace in Post-Agreement Northern Ireland: An Interpretative Phenomenological Analysis'. Political Psychology 28.1: 69-88.

Della Porta, Donatella, and Gary La Free. 2012. 'Guest Editorial: Processes of Radicalization and De-radicalization'. International Journal of Conflict and Violence 6: 4-10.

Doyle, Michael W., and Nicholas, Sambanis. 2000. 'International Peacekeeping: A Theoretical and Quantitative Analysis'. American Political Science Review 94.4: 779-801.

Ferguson, Neil. 2010. 'Disarmament, Demobilization, Reinsertion and Reintegration: The Northern Ireland Experience'. In Post-Conflict Reconstruction, ed. Neil Ferguson. Newcastle upon Tyne: Cambridge Scholars Publishing, 151-164.

Ferguson, Neil. 2011. 'Disengaging from Terrorism'. In The Psychology of CounterTerrorism, ed. Andrew Silke. London: Routledge, 111-122.

Ferguson, Neil, Mark Burgess, and Ian Hollywood. 2008. 'Crossing the Rubicon: Deciding to Become a Paramilitary in Northern Ireland'. International Journal of Conflict and Violence 2.1: 130-137.

Ferguson, Neil, Mark Burgess, and Ian Hollywood. 2010. 'Who Are the Victims? Victimhood Experiences in Post Agreement Northern Ireland'. Political Psychology 31.6: 857-886.

Ferguson, Neil, Mark Burgess, and Ian Hollywood. 2015. 'Leaving Violence Behind: Disengaging from Politically Motivated Violence in Northern Ireland'. Political Psychology 36.2: 199-214.

Festinger, Leon. 1957. A Theory of Cognitive Dissonance. Stanford, CA: Stanford University Press.

Fillieule, Olivier. 2010. 'Some Elements of an Interactionist Approach to Political Disengagement'. Social Movement Studies 9.1: 1-15.

Fillieule, Olivier. 2015. 'Disengagement from Radical Organizations: A Process and Multilevel Model of Analysis'. In Movements in Times of Democratic Transition, ed. Bert Klandermans and Cornelis van Stralen. Philadelphia: Temple University Press, 34-63.

Foster, Mindi D., and Kimberly Matheson. 1999. 'Perceiving and Responding to the Personal/Group Discrimination Discrepancy'. Personality and Social Psychology Bulletin 25: 1319-1329.

Goodey, Jo. 200o. 'Biographical Lessons for Criminology'. Theoretical Criminology 4: $473-498$.

Grossman, Dave. 1996. On Killing: The Psychological Cost of Learning to Kill in War and Society. New York: Back Bay Books. 
Horgan, John. 2009. Walking away from Terrorism: Accounts of Disengagement from Radical and Extremist Movements. London: Routledge.

Horgan, John. 2014. The Psychology of Terrorism. London: Routledge.

Huddy, Leonie. 2001. 'From Social to Political Identity: A Critical Examination of Social Identity Theory'. Political Psychology 22.1: 127-165.

Humphreys, Macartan, and Jeremy M. Weinstein. 2007. 'Demobilization and Reintegration'. Journal of Conflict Resolution 51.4: 531-567.

Kingma, Kees. 2000. Demobilization in Sub-Saharan Africa: The Development and Security Impacts. Basingstoke: Macmillan.

Klandermans, Bert. 1997. The Social Psychology of Protest. Oxford: Blackwell.

Klandermans, Bert. 2003. 'Collective Political Action'. In Oxford Handbook of Political Psychology, ed. David O. Sears, Leonie Huddy, Robert Jervis. Oxford: Oxford University Press, 670-709.

Knight, Mark. 2008. 'Expanding the DDR Model: Politics and Organisations'. Journal of Security Sector Management 6: 1-18.

Jamieson, Ruth, Peter Shirlow, and Adrian Grounds. 2010. Ageing and Social Exclusion among Former Politically Motivated Prisoners in Northern Ireland and the Border Region of Ireland. Belfast: Changing Age Partnership.

Jaspers, Karl. 1970. Existenial Eluicidation. Chicago: University of Chicago Press.

McAuley, James W. 1994. The Politics of Identity: A Loyalist Community in Belfast. Aldershot: Avebury.

McAuley, James W. 2000. 'Mobilising Ulster Unionism: New Directions or Old?'. Capital and Class 70: 37-64.

McAuley, James W. 2001. 'Redefining Loyalism - An Academic Perspective'. IBIS Working Paper No. 4. Dublin: Institute for British-Irish Studies.

McAuley, James W. 2002. 'The Emergence of New Loyalism'. In Changing Shades of Orange and Green, ed. J. Coakley. Dublin: University College Press, 106-122.

McCauley, Clark, and Sophia Moskalenko. 2008. 'Mechanisms of Political Radicalization: Pathways toward Terrorism'. Terrorism \& Political Violence 20.3: 415-433.

McLeod, Jack M., and Dhavan V. Shah. 20og. 'Communication and Political Socialization: Challenges and Opportunities for Research'. Political Communication 26.1: 1-10.

Mika, Harry. 2006. 'Community-Based Restorative Justice in Northern Ireland: An Evaluation'. Institute of Criminology and Criminal Justice, Queens University Belfast.

Moloney, Ed. 2010. Voices from the Grave: Two Men's War in Ireland. London: Faber \& Faber.

Oberschall, Anthony. 2004. 'Explaining Terrorism: The Contribution of Collective Action Theory'. Sociological Theory 22: 26-37. 
Petrovic, Igor, Jacquelien van Stekelenburg, and Bert Klandermans. 2014. 'Political Socialization and Social Movements: Escaping the Political Past'. In The Palgrave Handbook of Global Political Psychology, ed. Catarina Kinvall, Paul NesbittLarking, and Tereza Capelos. London: Palgrave, 403-422.

Rashwan, Diaa. 2009. 'The Renunciation of Violence by Egyptian Jihadi Organizations'. In Leaving Terrorism Behind: Individual and Collective Disengagement, ed. Tore Bjorgo and John Horgan. London: Routledge, 113-132.

Reinares, Fernando. 2011. 'Exit from Terrorism: A Qualitative Empirical Study on Disengagement and Deradicalization among Members of ETA'. Terrorism and Political Violence 23: 780-803.

Rolston, Bill. 2007. 'Demobilization and Reintegration of Ex-Combatants: The Irish Case in International Perspective'. Social \& Legal Studies 16.2: 259-280.

Runciman, Walter G. 1966. Relative Deprivation and SocialJustice. London: Routledge. Silke, Andrew. 2003. 'Becoming a Terrorist'. In Terrorists, Victims and Society: Psychological Perspectives on Terrorism and Its Consequences, ed. Andrew Silke. Chichester: Wiley, 29-53.

Sinnerton, Henry. 2003. David Ervine: Uncharted Waters. Dingle: Brandon.

Shirlow, Peter, and Kieran McEvoy. 2008. Beyond the Wire: Former Prisoners and Conflict Transformation in Northern Ireland. London: Pluto.

Shirlow, Peter, Brian Graham, Kieran McEvoy, Felim O'hAdhmaill, and Dawn Purvis. 2005. Politically Motivated Former Prisoner Groups: Community Activism and Conflict Transformation: A Research Report Submitted to the Northern Ireland Community Relations Council. Belfast: NICRC.

Shirlow, Peter, Jonathan Tonge, James W. McAuley, and Catherine McGlynn. 2010. Abandoning Historical Conflict? Former Paramilitary Prisoners and Political Reconciliation in Northern Ireland. Manchester: Manchester University Press, 2010.

Taylor, Peter. 1999. Loyalists. London: Bloomsbury.

Tonge, Jonathan, Máire Braniff, Thomas Hennessey, James W. McAuley, and Sophie A. Whiting. 2014. The Democratic Unionist Party: From Protest to Power. Oxford: Oxford University Press.

Van Stekelenburg, Jacquelien, and Bert Klandermans. 2007. 'Individuals in Movements: A Social Psychology of Contention'. In The Handbook of Social Movements across Disciplines, ed. Conny M. Roggeband and Bert Klandermans. New York: Springer, 157-204.

Van Stekelenburg, Jacquelien, and Bert Klandermans. 2013. 'The Social Psychology of Protest'. Current Sociology 61.5-6: 886-905.

Vidino, Lorenzo. 2011. 'The Buccinasco Pentiti: 'A Unique Case Study Of Radicalization'. Terrorism and Political Violence 23: 398-418. 


\title{
$7 \quad$ Social Movements and Social Movement Organizations
}

\author{
Recruitment, Ideology, and Splits ${ }^{1}$
}

Robert W. White and Tijen Demirel-Pegg

\section{Social Movements and Social Movement Organizations}

A common interpretation of the Irish 'Troubles' is that they began in the late 196 os when counterdemonstrators supported by the Royal Ulster Constabulary (RUC) attacked peaceful civil rights protesters. 'Out of the Ashes' of August 1969 arose the Provisional Irish Republican Army (IRA) and 'Provisional' Sinn Féin. It is also widely assumed that the conflict ended in 1998 when the Provisionals accepted the Good Friday Agreement and settled for a reformed Northern Ireland (see also Bosi and De Fazio, in this volume).

The transformation of the Provisionals from revolutionaries to constitutional politicians is only part of the story, however. The Provisional IRA and Sinn Féin were not the Irish republican movement. They were two of several 'players' in the Irish republican 'arena' between 1969 and 1998 (Jasper 2015; Mische 2015; Bosi and Della Porta 2012). Other organizations included Cuman na mBan and the Irish National Liberation Army. Placing the Provisionals in the context of the Irish republican movement allows an examination of their origins and how they changed over time, and shows how they were part of a series of waves of Irish republicanism.

Tarrow (1989) argues that mobilization occurs in waves and focuses on processes of escalation and de-escalation in recruitment. Placing an organization in the context of the social movement as a whole provides insight on organizational dynamics during waves of recruitment and during the 'lean' years between waves.

The timing of recruitment, the geographic location of new members, and their political background/upbringing, influence the new recruit's understanding of what s/he joined (ideology). When founding members

1 Revised paper presented at the first annual Ruairí Ó Brádaigh Summer School, Roscommon, Ireland, June 2014. Thanks to Lorenzo Bosi, Gianluca De Fazio, Dieter Reinisch, Margaret White, and Terry F. White for their help and comments. 
Figure 7.1 Heuristic Model

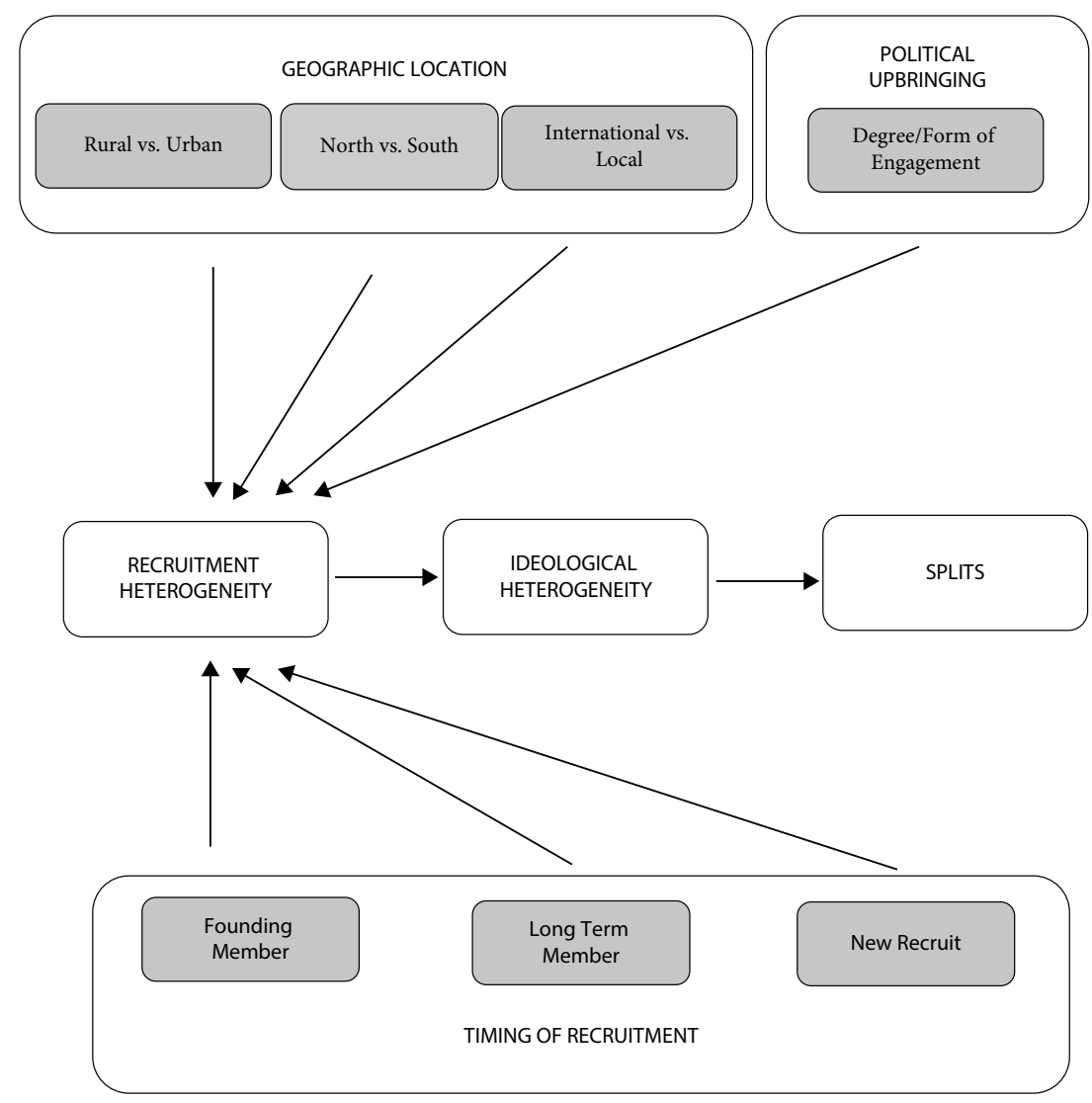

recruit new members, the new recruits enter an organization whose members have already established an understanding of who they are and what they are about. Even if new recruits join because of a commitment to the organization's ideology, a certain level of heterogeneity is inevitably introduced (see also White 1993, 2017; Weinstein 2007). The politics of where the new members live, their upbringing and family politics, and the timing of recruitment also influence the level of cohesion and homogeneity among members. Membership heterogeneity influences the likelihood of splits. For example, heavy state repression may create conditions for mass mobilization, but it may also bring in members who are more likely to be co-opted. An end to repression may satisfy new recruits but not founding members whose significant sacrifices in pursuit of a full victory pre-date the arrival of the new recruits. In summary, geographic location, family political background/upbringing, and the timing of recruitment contribute 
to the heterogeneity of movements, leading to factions and splits (Garner and Zald 1987; Freeman 1978; Gamson 1990; Demirel-Pegg forthcoming).

Figure 7.1 is a heuristic. We acknowledge, for example, that the timing of recruitment may directly influence ideology and that external factors influence splits (e.g. Balser 1997). The figure does not convey the full dynamics of activism. Instead, it is an attempt to convey important mechanisms associated with activism, as found in the following case study of Provisional Irish republicans within the context of the Irish republican movement.

\section{In the Beginning: The Wave of the Early 1970 s}

In August 1969, the RUC was unable to maintain order in Derry and violence spread to other areas of Northern Ireland. In Belfast, nationalist/Catholic neighbourhoods were attacked by Protestant/loyalist vigilantes and the RUC. A Belfast respondent described what happened in his neighbourhood ${ }^{2}$ :

Clonard republican: I lived in an area that was called the Clonard. The Clonard area in '69, Bombay Street is in the area, right? The Clonard is completely - it's smaller, it has thirteen streets, right? At the bottom of the street it - [it is a] fringe off the Shankill Road area. In '69 the area was attacked from the Shankill Road along Lawnbrooke Avenue by B Men, which were sort of paramilitary reservish policemen. The loyalists attacked the area. At that time there was only a couple of hunting guns in the area. Like shotguns. Nobody was able to defend the area, right? So, I decided, myself decided, the best way to defend the area is to get involved in the republican movement.

The respondent joined Na Fianna Éireann, the youth wing of the Irish republican movement.

Unrest from both communities escalated and on 9 August 1971 the British gave the Northern Irish government permission to introduce internment without trial. Even though nationalists and unionists had engaged in violence, only nationalist areas were targeted. Hundreds of nationalists were

2 Data collection began in 1984 and has continued through 2016. Respondents include a variety of activists - women and men, senior and junior level, from across Ireland, etc. The initial wave of interviews $(1984 / 85)$ may be the most representative data ever collected from activists associated with a social movement engaged in an armed campaign(White 1993). Some quotations have been presented elsewhere. 
interned without charge or trial (McGuffin 1973). This respondent joined the Provisionals after the introduction of internment:

Belfast republican: I'd seen many people shot dead. I'd seen friends' fathers who had been taken away and interned. I had friends whose relatives and maybe brothers and things like that were taken to Holywood, the interrogation centre at the time, and tortured. And all that from 1969 right up to just after internment, that was a real awakening for me on the injustices of the state.

On Sunday, 30 January 1972, at an anti-internment march, British soldiers shot dead thirteen unarmed nationalist/Catholics; a fourteenth died later. 'Bloody Sunday' influenced this respondent, from Derry:

Derry republican: It wasn't an emotional response, that 'I hate the Brits it's about time I did something', you know? It was just that I'd always been concerned, I'd always been motivated towards things Irish and it was just another - it was just another act of political vandalism on Irish people. [...] The British were killing our people, they were locking them up and they were nothing more than Stormont [the Northern Ireland government].

These respondents were influenced by violence, defending a neighbourhood from loyalists and suffering repression at the hands of the RUC and the British Army (see also De Fazio 2013; Demirel-Pegg 2014).

Not every Northern Irish recruit immediately joined the Provisionals in response to state or loyalist violence. Factors like the belief that political violence would be effective and camaraderie with peers influenced their decision-making processes (Bosi and Della Porta 2012; Klandermans 1984; McAdam 1999; White 1989). The repression also interacted with family background. Persons from republican backgrounds were more easily and more quickly recruited. The respondent from Clonard was from a republican family and joined relatively quickly in response to August 1969. The respondent from Derry, who was not from a republican family, joined the Provisionals more than a year after Bloody Sunday (see also Bosi 2012). Also, the violence did bring in recruits who were not from Northern Ireland but were mobilized because state violence was an affront to their sense of national identity.

What is important is that the state violence created a fertile ground for the founders of the Provisionals as they sought recruits from all over Ireland. As the state's response de-legitimated the state's authority, young Northern Irish nationalists came to believe that they were second-class citizens in 
a state that could not be reformed. Their best political choice, it seemed, was to support armed struggle for a united Ireland via the Provisional IRA and Sinn Féin. Family upbringing may have facilitated recruitment, but state repression turned the Provisionals into a mass movement in Northern Ireland (Bell 1979; White 2017).

Understanding this mass mobilization and the heterogeneity it introduced is essential for understanding why the Provisionals were willing to settle for the Good Friday Agreement. As the conflict continued, young northerners - many of whom were recruited in the early 1970s - came to dominate the Provisionals. Belfast ended up with more Provisionals than any other area of Ireland. Key younger people moved into leadership positions, including Gerry Adams in Belfast and Martin McGuinness in Derry. Finally, because those in the war zone suffered disproportionately, the Northern voice became especially important.

At some point in the early 199os, the new Provo leadership realized that armed struggle was not going to lead to a united Ireland. A negotiated peace that fell short of a united Ireland but led to a reformed Northern Ireland where they would have a political voice became an attractive option for people who had been deeply influenced by state violence in the early 1970s. The Good Friday Agreement, which promised that Irish nationalists would no longer be treated as second-class citizens in Northern Ireland, was a significant achievement. The people who settled for reform were not necessarily the people who created the Provos, however.

\section{Before the Provisionals}

Modern Irish republicanism dates from the failed Easter Rising of 1916. Between 1919 and 1921, the IRA and Sinn Féin re-grouped and pursued a guerrilla war and a political campaign for an independent Irish republic. In response, the British passed the Government of Ireland Act (1920) and partitioned Ireland into the six counties of Northern Ireland, where the majority Protestant population wanted to remain a part of the United Kingdom, and the Irish Free State (declared the Republic of Ireland in 1949), where the vast majority of the people were Catholic and wanted an independent Irish Republic. The IRA and Sinn Féin split over the Anglo-Irish Treaty (1921), which confirmed separate parliaments in Dublin and Belfast. Irish republicans who rejected the treaty lost the Irish Civil War that followed but maintained the IRA and Sinn Féin and continued their pursuit of an all-Ireland republic. There were failed IRA campaigns in the 1940s and 1950s in pursuit of an independent and united Ireland (Bell 1979). 
When the violence flared in Northern Ireland in August 1969, Irish republicans disagreed on the most appropriate response. The then leadership of the IRA and Sinn Féin, veterans from the 1940 s and 1950s, argued that the IRA and Sinn Féin should recognize the Dublin, Belfast, and London parliaments and combine armed struggle with constitutional politics. The people who created the Provisional IRA and Sinn Féin were also veterans from the 1940 s and 1950s. This group of people believed that recognizing those parliaments violated fundamental principles and would be a strategic mistake. Their view was that participation in constitutional politics would inevitably lead to co-optation and settling for reforms that were short of a united Ireland. The disagreement led to a split of the IRA in December 1969 into the 'Official' IRA and the 'Provisional' IRA. In January 1970, Sinn Féin split into 'Official' Sinn Féin and 'Provisional' Sinn Féin.

Most important, the people who created the Provisionals were different from the young recruits of $1969-1972$. The people who created the Provisionals were involved in the movement prior to August 1969. In Tyrone's Struggle, Gerard Magee quotes a pre-1969 IRA volunteer who said, 'I didn't need to be struck over the head by an RUC baton to become an active republican' (Magee 2011:124). To paraphrase a critic of Martin McGuinness, 'He got his start throwing rocks at the RUC'. The Irish republican movement spans Ireland. In August 1969, and because of where they lived, some Irish republicans were not in a position to be hit by officers of the Royal Ulster Constabulary.

Joe Cahill (1920-2004) helped create the Provisionals. He was born in Belfast in 1920. In contrast to many of the young northerners of 1969-1972, he was born into the Irish republican tradition:

Interviewer: [...] why in general did you get involved in the movement?

Joe Cahill: Yeah. I suppose it was the environment that I grew up in the '3os - poverty, and unemployment, and that sort of thing, you know? I felt that something had to be done about it. I became involved with various groups as a young lad. But I soon came to the conclusion that the root of all the trouble in Ireland was British occupation. And I suppose education through reading about Tone, people like that. The only way forward was to break the connection with England [...].

Interviewer: You're from a republican background?

Joe Cahill: I would be, yeah. Both my father and mother had been involved one way or another in the Republican Movement. 
Cahill grew up in an environment where state repression was a part of life and armed struggle for a united Ireland was an accepted response. He joined the IRA in the 1930s and was jailed during the IRA campaigns of the 1940 s and 1950s. He resigned from the IRA in the mid-196os because they were not militant enough. In August 1969, he returned and with others in Belfast helped create the Provisionals.

Most of the people who created the Provisionals did not live in Belfast or even Northern Ireland, however. Of the seven people on the Provisional IRA's first Army Council, five of them lived in 'southern Ireland' (the exceptions were Joe Cahill and Leo Martin, from Belfast). ${ }^{3}$ Of the 20 people on the 'Provisional' Sinn Féin Caretaker Executive established in 1970, only two were from Northern Ireland.

Ruairí Ó Brádaigh (1932-2013), from Longford in the Irish midlands, was Chairman of the Caretaker Executive. He was the son of an IRA veteran wounded in 1919:

Ruairí Ó Brádaigh: He and another man, another volunteer, Willie McNally, attempted to disarm two members of the Royal Irish Constabulary, the predecessors of the RUC and the PSNI, and they were overcome by the two policemen. And both of them were wounded, my father very severely wounded, and he was disabled for life.

Ó Brádaigh's mother was a veteran of Cumann na mBan, an independent women's organization founded in 1914:

Ruairí Ó Brádaigh: She was O/C or captain of the Cumann na mBan branch in Donegal Town in 1917 and '18 and then when she went to Dublin as a student at University College Dublin. She was a member of the college branch of Cumann na mBan and took part in all its activities.

Like Joe Cahill, Ó Brádaigh grew up in a household that valued Irish culture:

Ruairí Ó Brádaigh: Tuesday and Friday evening, paying a penny each, we were sent to Irish classes in the town, from five o'clock to seven. The first hour being Irish language and history and second hour being ceili dancing, Irish dancing, and with an annual fancy dress ceili and all that - cultural activities.

3 'Southern Ireland' refers to the Irish Free State/Republic of Ireland, parts of which are north of Northern Ireland. We argue that Irish Republicans born and raised in Northern Ireland are politically and socially different from persons born and raised elsewhere. 
Ó Brádaigh joined Sinn Féin in $195^{\circ}$ and the IRA in 1951. He was Chief of Staff at the end of the 1956-1962 IRA campaign. He was on the Provisional IRA's first Army Council and became the first President of 'Provisional' Sinn Féin (henceforth, Sinn Féin). The founders of the Provisionals, Joe Cahill, Ruairí Ó Brádaigh, and their contemporaries, were middle-aged men and veteran activists.

When the Provisionals were created, there were also other organizations, including the 'Official' IRA and 'Official Sinn Féin'. Cumann na mBan opposed the 1921 treaty and after the Irish Civil War held political values parallel to those of the IRA and Sinn Féin. Peig King joined in Dublin in the 1940s. Like Cahill and Ó Brádaigh, she was from a republican family. When she joined, her older sister was already a member:

Interviewer: Why did you get involved in Cumann na mBan?

Peig King: In Cumann na mBan? I knew about Cumann na mBan, my mother was in it. And all along the line, my father and mother was involved...

Interviewer: When did she get involved?

Peig King: She was involved when - she was in Dublin in 1916. [...] She was involved all along, right. My father was involved as a young man. [...]

Interviewer: Was he an IRA Veteran?

Peig King: Yes, he was. Yes. Yeah.

In $1969 / 70$, the Cumann na mBan leadership agreed with the political analysis of those who founded the Provisionals (Reinisch 2016). Peig King, while still a member of Cumann na mBan, joined Sinn Féin in 1970.

\section{Recruitment, Ideology, and Resistance to Change - And a Second Wave of Recruits}

Joe Cahill, Ruairí Ó Brádaigh, Peig King, and their contemporaries, joined small, clandestine organizations, not mass movements. They shared political backgrounds and accepted the view that the Dublin and Belfast governments established by the Government of Ireland Act (1920) were illegitimate. Their allegiance was to an all-Ireland government that was 
suppressed in the 1920 s and abandoned by former comrades of their parents.

Depending upon where they were born and raised, however, the people who created the Provisionals grew up in very different worlds. Joe Cahill grew up in Northern Ireland, which was predominantly Protestant and proUnion, and where Catholics/nationalists were second-class citizens. Ruairí Ó Brádaigh grew up in the Irish Free State/Republic of Ireland, which was predominantly Catholic and Irish nationalist in outlook. Because of their politics, both of them suffered repression at the hands of their respective governments. Cahill and his fellow northerners were also victims of social oppression because of their religion and their sense of national identity. For many northerners, the Dublin government was not legitimate, but it was also distant and appeared relatively benign.

As the Provisionals carried on their campaign to re-unite Ireland, some of their founders, including Joe Cahill and Ruairí Ó Brádaigh, were arrested. Others aged and left the scene. With time, younger people - especially people born and raised in Northern Ireland - moved into leadership positions. With them came change. For example, at the initiative of young northerners, the Provisional IRA adopted a cell structure (small active service units) in the late 1970s.

The new leaders also tried to disband Cumann na mBan and fold its members into the Provisionals. From their perspective, the Provisionals were progressive and there was no need for a separate women's organization. From the Cumann na mBan perspective, there was a concern that the new leadership was trying to find a way to better control women activists. Cumann na mBan refused to go along with the plan (though some women did leave for the Provos):

Interviewer: Why is it important that there's a separate women's organization?

Cumann na Mban activist: I think it's important from the point of view that women tend to become subsumed - well at that particular time [1970s] women's role was more I think subservient than it would be now, you know? Women were only just kind of standing up and being counted. And I think it was always important for the Republican Movement that women had a separate voice and could stand up for themselves. Because even now I think that women in the male military organization are very much at the mercy of their male counterparts. And I would rather, as a woman, have my own voice and be able to make it known. 
The key point here is that the beliefs and ideology of members of a preexisting organization were so strong that they refused to be absorbed into a larger movement organization with the same goal. This did not stop the younger people from changing the Provisionals in other ways.

A second wave of new recruits, generated by the 1980-1981 hunger strikes, solidified the control of the younger and northern leadership (White 2017; see also O'Hearn, this volume). Led by Gerry Adams, Martin McGuinness, and Danny Morrison, the new leaders changed Sinn Féin's policy so that elected representatives could take seats in the Dublin parliament. They also promised that they would never take seats in a Northern Ireland parliament. That promise made it easier for senior northerners, like Joe Cahill, to accept the change.

The opposition to taking seats in the Dublin parliament was led by people recruited long before there were Provisional Irish republicans, senior 'southerners' (or, non-northerners) like Ruairí Ó Brádaigh. They, and their families, had personally experienced repression at the hands of the Irish Free State/ Republic of Ireland; the illegitimacy of the Dublin government was immediate for them. They walked out of the 1986 Sinn Féin Ard-Fheis (convention) and created two rival social movement organizations, Republican Sinn Féin (RSF) and the Continuity IRA. Cumann na mBan also opposed taking seats in the Dublin parliament.

The 1986 split has several implications for studying social movements and their organizations. What happens in one movement organization, like Sinn Féin, influences other movement organizations, like Republican Sinn Féin and Cumann na mBan. From 1986 on, RSF and Cumann na mBan (two small organizations) adopted a mutually supportive approach and several members of Cumann na mBan would become officers in RSF; today, Peig King is the 'Patron' of Republican Sinn Féin. Cumann na mBan did not join RSF en masse or through bloc recruitment, but their influence on RSF is undeniable (Ní Chathmmhaoil and Reinisch 2014).

The split also shows that when and where someone is recruited influences that person's understanding of what s/he has joined and the course of his/her activism, which has been noted previously (see also White 1993; White 2010; Weinstein 2007; Viterna 2013). As Sarah Campbell (in this volume) nicely demonstrates, collective identities promote solidarity among members of a social movement. At the same time, differences in collective identities across subgroups of activists in the same organization may promote factions and splits. This was demonstrated a second time in 1997.

Eleven years after the first split, the senior northerners still active in the Provisionals, including Joe Cahill, went along with the (still relatively) young leadership as they negotiated the Irish peace process. The primary 
opposition was a group of activists who were willing to accept Sinn Féin taking seats in the Dublin parliament but who questioned the Provisional IRA's ceasefire in 1997 and, later, the Good Friday Agreement. They challenged the leadership and created the 32 County Sovereignty Committee, which they described as a pressure group within Sinn Féin. Of the 16 people on the committee's 'Executive', only four were from Northern Ireland. They were committed to a united Ireland, not a reformed Northern Ireland where many of them did not live. After being expelled from Sinn Féin, they re-organized as the 32 County Sovereignty Movement. It is alleged that the 32 CSM is the 'political wing' of the Real IRA (Mooney and O'Toole 2003).

\section{The Irish Republican Movement: 1998 to Today}

The Irish republican movement did not end with the Good Friday Agreement in 1998. Post-1998, Sinn Féin politics dominated the Provisionals to the extent that the Provisional IRA formally ended its campaign and decommissioned weapons in 2005. And the peace process has been good to Sinn Féin. In Northern Ireland, they are the second largest party and Martin McGuinness served as the Deputy First Minister of the Northern Ireland Assembly until 2017 - in spite of having promised to never serve in such an assembly. In the Republic of Ireland, Sinn Féin is the third largest political party and Gerry Adams is leader of their parliamentary party in Dáil Éireann (the Dublin parliament). North and south, Sinn Féin's representatives still advocate for a united Ireland.

Republican Sinn Féin, the Continuity IRA, the 32 County Sovereignty Movement, the Real IRA, and Cumann na mBan, all rejected the Good Friday Agreement and continued as social movement organizations. After 2005 more organizations appeared, including Éirigi, the Republican Network for Unity (RNU), and the Óglaigh na hÉireann (ÓNH). A focus on the Irish republican movement brings the activities of these groups into view, and also provides more insight on the transformation of the Provisionals.

Indeed, this case study offers insight on what happens between waves of mobilization and de-mobilization. The process of recruitment to organizations that reject the Good Friday Agreement appears to be similar to the recruitment process of those who joined after the mass mobilization of 1916-1923 but prior to the mass mobilization of the early 1970s. The following is from an activist who joined Republican Sinn Féin in 2000:

Republican Sinn Féin activist 1: I would like to say I just woke up one morning and decided I wanted to see the freedom of my country, but I was 
brought up in a very republican household, in the republican tradition [...] I've been reared in the republican tradition and I've always known that, you know, we're under occupation and that the freedom of your country is a noble aspiration, it's not something you should be ashamed of.

Like Joe Cahill, Ruairí Ó Brádaigh, and Peig King, this activist was strongly influenced by family background. When armed struggle by Irish republican activists is limited - in the 1930s (Cahill), the 1940s (King), the early 1950s (Ó Brádaigh), and the 2000 - family connections are that much more valuable a source of recruits (see Veugelers 2011; Della Porta 1988).

Family connections and repression have never been the only source of recruits to the Irish republican movement. Another person who joined Republican Sinn Féin in the early 2000 commented:

Republican Sinn Féin activist 2: I suppose just all my life I've felt that continued British rule in Ireland was unjust and immoral as well as illegal and so I suppose in a sense it was merely inevitable [that I would become involved].

The Good Friday Agreement did not resolve the fundamental issue that has sustained Irish republicanism since the 1790s. Ideology, the belief that Ireland should be free, continues to motivate recruits to organizations that engage in armed struggle.

However, family connections and the belief that Ireland should be free do not provide recruits to the degree that events like August 1969, internment, and Bloody Sunday sent recruits into the Provisionals in droves. Compare 'I was brought up in a very republican household' and 'British rule in Ireland was unjust and immoral as well as illegal' with 'The best way to defend the area is to get involved in the republican movement'. If, in the early 2000 , there had been a re-occurrence of widespread state repression, there might also have been a groundswell of support for organizations like the Continuity IRA and the Real IRA. That did not happen.

In the wave of mobilization that generated the Provisionals, the British learned that widespread repression was counterproductive in Northern Ireland. Therefore, they turned to selective repression, a more sophisticated approach. In response to continued political violence from so-called 'dissident' organizations, the British, Irish, and Northern Irish (which includes Sinn Féin) governments have replaced the counterproductive repression of the early 1970 s with a more sophisticated approach - 'internment by remand'. Dissent is selectively repressed. Martin Corey was arrested in 
April 2010. A 'Release Martin Corey' campaign was organized, but because he was one person its appeal was less successful than the anti-internment campaign of 1971-1972; the anti-internment march on Bloody Sunday attracted thousands. Corey's attorneys were not allowed to view the evidence against him, he was never allowed a parole hearing, and when he was finally released in January 2014 - without ever being charged - it was with restrictions. Activists in the Irish republican movement still face repression, even if the Provisionals do not.

There is also a curious situation with respect to Cumann na mBan. Sinn Féin claims that it is progressive on women's issues. Policies were adopted to enhance the role of women in Sinn Féin and the party proudly promotes women candidates and its elected women representatives. Michelle O'Neill, for example, is the party's new leader in Northern Ireland. The party also embraces Cumann na mBan's historic contribution to Irish republicanism, including having women dressed in 1916-1922 era Cumann na mBan uniforms appear at their events. And yet, while promoting women's activism, and because Cumann na mBan did not follow the Provisionals into constitutional politics, Sinn Féin claims that the organization ceased to exist in the late 1980 .

Cumann na mBan still exists, still sees the Dublin and Belfast parliaments as reformist institutions established by the British to maintain their rule in Ireland, and still considers itself a revolutionary organization:

Interviewer: I've heard it said that the more progressive women got involved in the movement more generally, and weren't interested necessarily in a women's organization because they felt they were equal, etc.

Cumann na Mban activist: Is that like in the Provisionals?

Interviewer: Yes.

Cumann na Mban activist:Yes, indeed, they were the ones that followed their men very, very, quietly into constitutional politics. And that's the answer to that. I mean, they weren't revolutionary. I know most of those women. And I was with them in Sinn Féin. Some of them would have been in Cumann na mBan at times. But if you look at Sinn Féin [...] you had this idea of having eight places reserved on the Ard Chomhairle for women. I never agreed with that. I think people should be recognized on their merits. And in Republican Sinn Féin [...] We don't have tokenism, you know? [...] Revolutionary women would stand by the Republic and 
stand by what they believe in and they won't worry about their husbands or their boyfriends, or their brothers or sisters - brothers, you know, and they stick up to their beliefs.

Interviewer: Are you a revolutionary?

Cumann na Mban activist: I would think so. I've always been a revolutionary.

For some observers, the women who stayed with Cumann na mBan, were less progressive and less feminist than their counterparts who went into the Provisionals (O'Keefe 2013: 135; see also O'Keefe, in this volume). This Cumann na mBan activist argues that the women who went with the Provisionals lost their revolutionary way.

\section{Summary}

Placing the Provisional IRA and Sinn Féin within the 'arena' of the broader Irish republican movement and following these two organizations over time offers insight on their transformation and the rise of anti-Good Friday Agreement 'dissidents' who pursue armed struggle today. Preexisting organizations, the timing of recruitment, and different belief systems among groups of activists influenced the Provisionals. So did events post-1969.

More generally with respect to activism, the Irish republican movement has experienced waves or cycles of mass mobilization, as occurred in 1919-1921 following the Easter Rising, in the early 1970s in response to state violence, and in 1980-1981 in response to the hunger strikes. Yet, the dynamics of activism during the lean years cannot be ignored. Even if the number of recruits is smaller between waves of recruitment, differences in the nature of recruitment during these years versus recruits brought in during a mass mobilization are important, as they may lay a foundation for splits.

Many social movements have lengthy histories with multiple social movement organizations. Without question, in-depth case studies of recruitment into specific organizations, including studies that focus on a particular period of time, have value. However, this case study of Provisional Irish republicans, over time and in the context of the broader Irish republican movement, shows that we cannot assume that activists within the same 
movement (or even the same social movement organization) experience the same recruitment process. These differences contribute to movement heterogeneity and organizational change. Finally, the persistence of some organizations in the face of external opposition from states and internal opposition from other movement organizations, like Cumann na mBan, merits further consideration.

\section{Interviews}

Belfast Republican, 1996

Clonard Republican, 1984

Cumann na mBan activist, 2009

Derry Republican, 1985

Joe Cahill, 1996

Peig King, 2009

Republican Sinn Féin activist 1, 2011

Republican Sinn Féin activist 2, 2011

Ruairí Ó Brádaigh, 2009

\section{Works Cited}

Balser, Deborah B. 1997. 'The Impact of Environmental Factors on Factionalism and Schism in Social Movement Organizations'. Social Forces 76.1: 199-228.

Bell, John Bowyer. 1979. The Secret Army: The IRA 1916-1979. Dublin: Academy Press.

Bosi, Lorenzo. 2012. 'Explaining Pathways to Armed Activism in the Provisional Irish Republican Army, 1969-1972'. Social Science History 36.3: 347-9o.

Bosi, Lorenzo, and Donatella della Porta. 2012. 'Micro-mobilization into Armed Groups: The Ideological, Instrumental and Solidaristic Paths'. Qualitative Sociology 35.4: 361-383.

Bosi, Lorenzo, and Simon Prince. 2009. 'Writing the Sixties into Northern Ireland and Northern Ireland into the Sixties'. The Sixties: A Journal of History, Politics, and Culture 2.2: 145-161.

De Fazio, Gianluca. 2013. 'The Radicalization of Contention in Northern Ireland, 1968-1972: A Relational Perspective. Mobilization 18.4: 475-96.

Della Porta, Donatella. 1988. 'Recruitment Processes in Clandestine Political Organizations: Italian Left-Wing Terrorism'. In International Social Movement Research, ed. B. Klandermans, H.P. Kriesi, and S. Tarrow. Greenwich, CT: JAI Press, 155-169. 
Demirel-Pegg, Tijen. 2014. 'From the Streets to the Mountains: The Dynamics of Transition from a Protest Wave to an Insurgency in Kashmir'. Mobilization 19.3: 309-327.

Demirel-Pegg, Tijen. Forthcoming. 'The Dynamics of the Demobilization of the Protest Campaign in Assam'. International Interactions. DOI: 10.1080/03050629.2016.1128430.

Freeman, Jo. 1978. 'Crises and Conflicts in Social Movement Organizations'. Chrysalis: A Magazine of Women's Culture 5: 43-51.

Gamson, William. 1990. The Strategy of Social Protest. Belmont, CA: Wadsworth.

Garner, Roberta Ash, and Mayer N. Zald. 1987. 'The Political Economy of Social Movement Sectors'. In Social Movements in an Organizational Society: Collected Essays, ed. Mayer N. Zald and John McCarthy. New Brunswick, NJ: Transaction, 293-317.

Jasper, James M. 2015. 'Introduction: Playing the Game'. In Players and Arenas: The Interactive Dynamics of Protest, ed. James M. Jasper and Jan Willem Duyvendak. Amsterdam: Amsterdam University Press, 9-32.

Klandermans, Bert. 1984. 'Mobilization and Participation: Social-Psychological Expansions of Resource Mobilization Theory'. American Sociological Review 49: 583-6oo.

Magee, Gerard. 2011. Tyrone's Struggle: Ar son Saoirse na hÉireann. Dublin: Brunswick Press.

McAdam, Doug. 1999. Political Process and the Development of Black Insurgency, 1930-1970. Chicago: University of Chicago Press.

McGuffin, John. 1973. Internment! Dingle: Anvil Books.

Mische, Ann. 2015. 'Fractal Arenas'. In Players and Arenas: The Interactive Dynamics of Protest, ed. James M. Jasper and Jan Willem Duyvendak. Amsterdam: Amsterdam University Press, 55-78.

Mooney, John, and Michael O'Toole. 2003. Black Operations: The Secret War against the Real IRA. Ashbourne: Maverick House.

Ní Chathmmhaoil, Líta, and Dieter Reinisch. 2014. Cumann na mBan: 100 Years Defending the Republic. Dublin: Cló Saoirse - Irish Freedom Press.

O'Keefe, Theresa. 2013. Feminist Identity Development and Activisms in Revolutionary Movements. London: Palgrave Macmillan.

Reinisch, Dieter. 2016. 'Cumann na mBan \& Women in Irish Republican Paramilitary Organisations, 1969-1986'. Estudios Irlandeses 11: 149-162.

Tarrow, Sidney. 1989. Democracy and Disorder: Protest and Politics in Italy, 1965-1975. Oxford: Oxford University Press.

Veugelers, John W.P. 2011. 'Dissenting Families and Social Movement Abeyance: The Transmission of Neo-Fascist Frames in Postwar Italy'. British Journal of Sociology 62.2: 241-261. 
Viterna, Jocelyn. 2013. Women in War: The Micro-Processes of Mobilization in El Salvador. Oxford: Oxford University Press.

Weinstein, Jeremy M. 2007. Inside Rebellion: The Politics of Insurgent Violence. Cambridge: Cambridge University Press.

White, Robert W.1989. 'From Peaceful Protest to Guerrilla War: Micro-mobilization of the Provisional Irish Republican Army'. American Journal of Sociology 94.6: 1277-1302.

White, Robert W. 1993. Provisional Irish Republicans: An Oral and Interpretive History. Westport, CT: Greenwood Press.

White, Robert W. 2006. Ruairí Ó Brádaigh: The Life and Politics of an Irish Revolutionary. Indianapolis: Indiana University Press.

White, Robert W. 2010. 'Structural Identity Theory and the Post-Recruitment Activism of Irish Republicans: Persistence, Disengagement, Splits, and Dissidents in Social Movement Organizations'. Social Problems 57-3: 341-370.

White, Robert W. 2017. Out of the Ashes: An Oral History of the Irish Republican Movement (Social Movements versus Terrorism). Newbridge, C. Kildare, Ireland: Merrion Press. 



\title{
8 Movement Inside and Outside of Prison
}

\author{
The H-Block Protest
}

Denis O'Hearn'

The vast majority of work on social movements concerns how people 'on the streets' mobilize material and symbolic resources in order to persuade people to expend time and take abnormal risks in hopes of achieving movement goals. ${ }^{2}$ Prisons are often regarded as places of confinement and immobility, especially cellular prisons and even more especially regimes of cellular isolation. Beginning with the H-Blocks in Northern Ireland during 1976-1981, there are many experiences of long-term cellular isolation around the world. The most notable examples are supermax prisons and security housing units (SHUs) in the United States after 1984 (now holding over 100,000 prisoners) and 'F-type' prisons of Turkey (housing 5000 mostly political prisoners). I argue here that prisons with cellular isolation are places of movement and communication, regardless of architecture and regime.

In past work on the H-Block prison movement I explored the impact of bare life on solidarity, arguing that the stripping of written media and consumer commodities freed prisoners to build a solidary community based on oral communication (O'Hearn 2009). I also explored how prison policy and strategies of resistance migrate across space and time (O'Hearn 2013, 2014). This chapter explores movement, in particular how prisoners may move into spaces and appropriate them for their own purposes. Moreover, they may 'move' across prison walls to connect to movements outside. Important factors in this story include attempts by prisoners to bring practices of resistance into the prison; ways in which communication and culture are achieved, although forbidden; the role of leadership/

1 Data sources, unless otherwise indicated, are provided in O'Hearn (2009: 504). A new analysis of the Irish blanketmen and other prisoners in solitary, as 'exilic communities' living on the edges of capitalism, is in Grubačić and O'Hearn (2016).

2 An excellent summary of this literature, both generally and with regard to Ireland, is provided in Bosi and De Fazio (in this volume). From a resource mobilization and political process perspective, as well as for its ethnographic and historical insights, the work of Robert White (see White and Demirel-Pegg, in this volume) is especially noteworthy. 
expertise in such achievements; and the interactions between movement activists inside and outside of prison. In the H-Blocks, we shall see how movement parts that appear 'disadvantaged' and isolated from the main community of insurgents can nonetheless control movement campaigns and repertoires. The discussion ends with a review of the learning process the H-Block conflict enabled in Turkish and US prisons. This comparative history indicates that the Irish experience of imprisonment and prison struggle not only presents crucial lessons that are repeated in other places but even that isolated prisoners learn from other experiences and that of the blanketmen is among the most important.

The proposition that prisoners may mobilize significant movements may seem to contradict most of the resource mobilization and political process literature within the field of social movement studies (Morris and Herring 1987). In particular, it is assumed that social movements need both material (money, organizations) and symbolic (legitimacy, leadership, elite endorsement) resources to successfully mobilize people. In addition, they must have political opportunities that they can seize in order to challenge and exploit the vulnerabilities of a regime. Prisoners, it might appear, have few such resources: they have little money and are often indigent; they may or may not be associated with political organizations or so-called gangs but are often cut off from them by their prison isolation; leadership and formal organization may be elided by isolation; and they are usually regarded as social pariahs by most of the population.

On the other hand, and as we shall see in this chapter, prisoners are very creative at obtaining resources and they are extremely efficient at their use of what they have; they have an abundance of one particular resource, time, which enables them to organize and build new forms of communication despite physical and institutional obstacles and frequent failure; they may turn their arm's length relations with their parent organizations into a resource because they have the independence to create their own strategies and coalitions without seeking continuous approval by their 'superiors'; and the lack of access to written materials or face-to-face contact may be turned into a positive thing because the dependence on oral communication may enable much deeper relations of solidarity than is otherwise possible.

\section{Background: Movement from Open to Cellular Prisons}

In the early 1970s, Northern Irish prisoners found guilty of politically motivated offences were given 'Special Category' (political prisoner) status. The 
state also interned thousands without trial, mostly young Catholic men. Convicted and interned prisoners were kept in 'cages' with Quonset huts and rudimentary wooden buildings in the hastily built Long Kesh prison. They self-managed their lives on a communal basis and organized revolutionary education, including history, Irish language, guerrilla warfare, and arms training. In time, they re-organized and radicalized the Irish Republican Army (IRA) and Sinn Féin from within prison walls. ${ }^{3}$

The British government soon realized that self-organization in a prison camp was not in their interests. In November 1975, it announced that anyone found guilty of an offence related to the conflict after 1 March 1976 would serve their time in a new cellular prison, HM Prison The Maze, in 'H-Blocks' built in the same complex as the 'cages'. By changing the prison's name the British hoped the controversy of internment would go away. Instead, prisoners refused to go silently into the new cellular regime and a new controversy emerged about long-term cellular isolation.

The new regime was simple. Prisoners were brought into the administration area of an H-Block (see figure 8.1) and told that they were criminals and would have to wear prison uniforms and perform prison work. Prison guards were 'Sir!' and prisoners were known by a number. Each prisoner was stripped and offered a prison uniform.

According to popular narrative, when the first IRA prisoner (Kieran Nugent) was offered a uniform, he said 'if you want me to wear that you'll have to nail it to my back'. The guards put him in a cell alone, without clothing or reading or writing materials, some rudimentary furniture, a towel, and blankets. From then, hundreds of men who refused to wear prison uniforms or do work were left naked in H-block cells. They draped

3 A short explanation is useful. The 'Republican Movement' that led the 1916 Easter Rising split after the partition of Ireland and creation of Northern Ireland in 1920/21. One side went into (Southern Irish) government and the other remained primarily committed to Irish unity, retaining the clandestine Irish Republican Army (IRA) and its associated political party Sinn Féin. This movement split again in 1969, into 'Official' and 'Provisional' wings. By the time covered in this article, the Official IRA had declared a ceasefire and the 'Provisional' republican movement could be accurately called the IRA, associated with the Sinn Féin. In this article, I refer to these two groups together as the republican movement or, simply, the movement. Although certain people identified with either the IRA or Sinn Féin, dual membership was common. In prison matters, people often acted as Sinn Féin representatives even though they came under the discipline and orders of the IRA. To complicate matters, an armed organization split from the Official republican movement in 1974 after the ceasefire: the Irish National Liberation Army (INLA), associated with the Irish Republican Socialist Party (IRSP). INLA blanketmen protested alongside IRA blanketmen, although in fewer numbers. 
Figure 8.1 Layout of an H-Block in Long Kesh prison

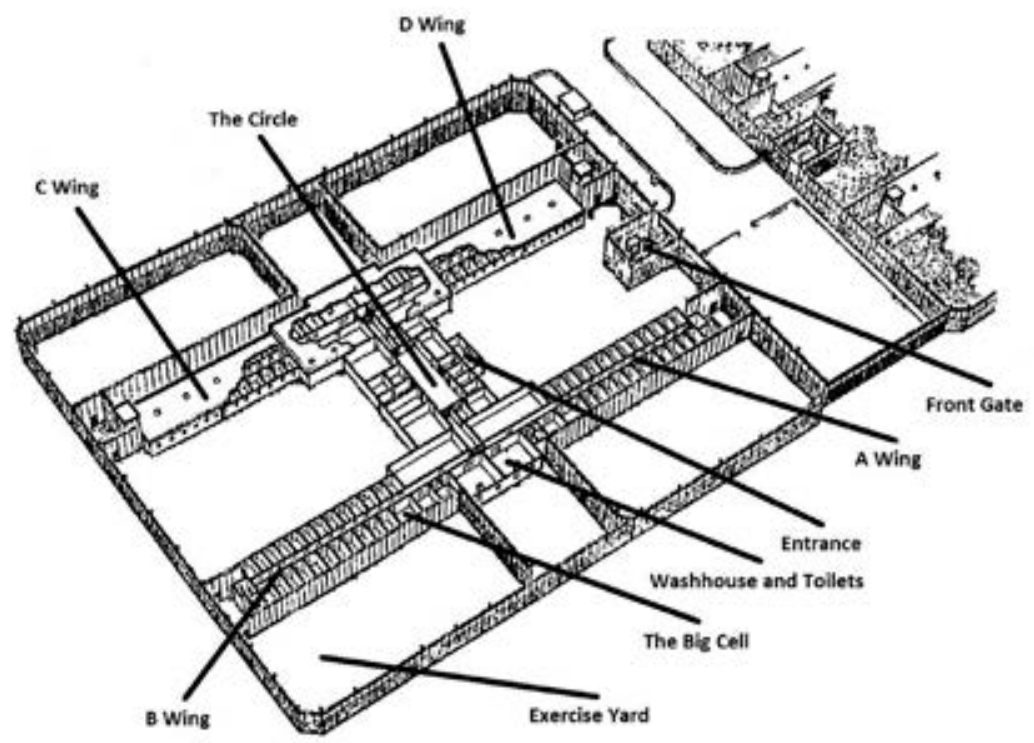

blankets around their waists and shoulders and thus became known as 'blanketmen'.

The blanketmen communicated by talking out of cell windows and shouting out the doors. Those on the inside of the ' $\mathrm{H}$ ' could shout to prisoners on the opposite leg. At night, they shouted from block to block. They developed creative ways of communicating like tying items onto a string unravelled from their blankets, tying the other end to a button, and 'shooting the button' across the corridor under cell doors. Their only outside communication was with priests, through whom they passed messages and received supplies including cigarette papers, ballpoint refills, and tobacco.

\section{Turning Immobility to Movement}

At first, a macho regime of total non-cooperation prevailed. The blanketmen stayed in their cells for two years, assuming that the British would eventually reinstate political status. This was a miscalculation. The authorities had no moral quandaries about keeping prisoners in bare conditions and, if asked, trotted out a standard explanation: the Maze was the most modern prison in Europe, if the men wanted to take advantage of its facilities all they 
had to do was to put on a uniform like any other criminal. It was difficult for prisoners to get word about their conditions to the public. A few family members organized small protests with little impact.

The blanketmen only came out of their cells to shower and, on Sundays, for mass. To attend mass they had to wear uniform trousers so 'harder' prisoners did not even come out then. Hardly anyone took their allotted monthly visit because they would have to wear a uniform to do so. That was considered capitulation to British oppression.

Two things changed passive protest to movement. First, key prisoners arrived and advocated coming out of cells. Then, the prisoners coordinated a protest campaign with outside supporters. As a result, by the time of the 1980-1981 hunger strikes in which ten blanketmen died, there was massive support for their campaign not only in Ireland but around the world.

In early 1978, Brendan Hughes, legendary IR A commander and close confidant of Gerry Adams, was transferred from the cages to the H-Blocks when found guilty of a minor infraction. Hughes became Officer Commanding (OC) of the IRA blanketmen. Bobby Sands was already 'on the blanket', convicted of charges related to a bombing mission. Hughes and Sands led a remarkable prison campaign from adjacent cells over the next four years. Instead of staying in their cells, they told blanketmen to take visits. Not only would it ease their lives and get information to the outside world, they could smuggle ballpoint refills, cigarette papers, tobacco, and communications (comms). ${ }^{4}$

Moving out of cells had consequences on relations between prisoners and guards. When blanketmen moved through 'their' spaces - corridors, dining halls, visiting areas - the authorities punished them, provoking further actions by the blanketmen, further punishments, and so on in an escalating pattern. Sunday masses became organizing meetings and smuggling zones; even the priests moved messages and material supplies for prisoners. But visits became the main source of supply and communication with the movement and public.

The second challenge was to build a support campaign outside of prison. Unfortunately, the republican movement did not support the prisoners much, apart from sending money to their families. Early support came from relatives of prisoners who formed a group called Relatives for Justice. Support by the IRA and the broader republican movement had to be built, by pressure from inside the prison.

4 Comms were messages written in tiny handwriting on cigarette papers or toilet paper. They were folded tightly into a small package and wrapped in cling film so that they could be smuggled internally in the body. 


\section{Appropriating Prison Spaces}

For years, the public knew little about conditions in the H-Blocks. Without visits, even the prisoners' families were unaware of their full degradation. Soon after he arrived in the H-Blocks in late 1977, Bobby Sands began smuggling articles through visits. His first article in the Sinn Féin newspaper Republican News gave readers their first description of life 'on the blanket'. 'Everyone with the exception of the latest arrivals has a beard of sorts. When I first arrived here I noticed that a lot of the men's eyes seemed to be sunk into the pits of their eyes, and everyone's face was a pale yellowish complexion' (O'Hearn 2006: 173). Another article starkly revealed the harsh winter conditions in the H-Blocks:

It is so cold that we are unable to walk upon the concrete cell floor in our bare feet; the water in the drinking container has frozen and my filthy foam mattress upon the ground is wet with the snow that came in through the window during the night.

I had no sleep again last night, my three flimsy blankets being no match for the biting bitter cold. I spent last night huddled up in a corner listening to many of my comrades coughing and groaning, whilst scores of men lay shivering from flu, fighting against high temperatures and severe pain. (O’Hearn 2006: 176)

Sands continued taking his monthly visits. His mother, Rosaleen, was such a magnificent smuggler that the prisoners called her 'old faithful'. If Sands had a visit, they knew they would have a smoke that night. This taught them that visits were not just a source of communications but also luxuries.

By himself, Sands could do little but when Hughes arrived in the H-Blocks and more blanketmen began taking visits things changed. They opened new lines of communications and got pens and other materials. 'It was quite tough at the time to go out of your cell and put on that prison uniform', said Hughes, yet taking visits lightened the protest. Prisoners saw loved ones and moved the protest forward.

Visits turned to confrontation when guards discovered the smuggling. They started strip-searching prisoners, probing their hair, mouths, and rectums. Forced squatting, bending, and probing became common; beatings increased (the issue of strip-searching would become even more controversial for women prisoners in Armagh jail).

Hughes and Sands were intensifying the protest. They wanted to increase publicity about their conditions and were aware that this would 
provoke further repression. Yet, they hardly predicted the escalation that followed.

Action and reaction combined in a creative process of confrontation. Both sides strategized and improvised. Familiar tactics from open prisons were adapted to new conditions in the H-Blocks; there was no predictability about the outcome. Despite brutal searches, smuggling raised prisoner morale by providing resources. And by taking risks for each other, the blanketmen became a tight, solidary community.

The authorities tested their solidarity at the weakest link: young prisoners (YPs). On the pretext that the H-Blocks were becoming overcrowded, the guards refused to let YPs out of their cells to wash. They boasted openly about how many YPs they could drive off the protest. The blanketmen decided if the YPs couldn't wash, no one would. On 20 March 1978, they refused to wash, shower, or clean their cells, beginning a long 'no-wash' protest (the authorities and media would it call a 'dirty' protest). Says Brendan Hughes, 'We basically slid into it. It wasn't a conscious decision [...] It was because of the situation, people getting brutalized going to the shower and so forth.'

Every Monday the prisoners introduced a new protest; in return, the guards introduced new punishments. After the prisoners refused to wash, the guards took away all soap, toothbrushes, toothpaste, and combs. When the authorities stopped supplying clean sheets, the prisoners threw their dirty sheets onto the landing. When the guards came to take away the few bits of furniture, the prisoners smashed it first.

Eventually, the authorities took away everything except food and human waste. When the prisoners tried to get rid of these, the guards gave them back. They refused to take leftover food so the prisoners had to throw it into the corner of the cell, where it piled up and bred mould and maggots. When they began slopping their urine under the doors, the guards squeegeed it back, leaving their foam mattresses sopping wet. When the prisoners threw their excrement out the window the guards threw it back. Eventually, they had to spread it on the cell walls.

Hughes and Sands recognized potential in all this. In Hughes's words, a series of unplanned events 'soon became a tactic'. If the mess escalated far enough, the authorities would have to grant them political status to bring order back into their 'modern' prison.

The prisoners interpreted each new punishment as a sign that they were winning. Says one ex-blanketman, 'Morale was sky high. We felt that we were winning and for a change that we, not the screws, had control over our lives because we dictated the pace of events' (O'Hearn 2009: 509). 
As morale improved, the community bonded tightly together. They invented new entertainments like the 'book at bedtime', where storytellers recited books from memory after the screws left the wing at night. Days were filled with lessons and debates. The number of prisoners fluent in Irish rose from a few to hundreds. A full-fledged solidary community developed. ${ }^{5}$

\section{Building Support}

To build a campaign, however, the movements inside and outside of prison had to be brought onto the same wavelength. When Hughes arrived in the H-Blocks he had been directing the IRA's armed campaign in Belfast. He knew how weak the IRA was after years of arrests and was among a handful of leaders who began restructuring the IRA from its old brigade system towards a secretive cell structure. 'We had an issue here that could give some help to the leadership on the outside. I knew that was the situation, and that's what we were doing' (Hughes, quoted in O'Hearn 2006, p. 182). Hughes also knew that movement leaders wanted to create a dynamic political party to agitate around social and economic issues. It would take years for the new structures to mature, if they even survived the onslaught by British security. In the meantime, Hughes thought the prison protest could provide a popular platform, allowing the movement to mobilize support while the IRA regrouped.

Yet, prisoners' rights were low on the movement's agenda. Gerry Adams thought that 'prisoners should always take second place'. Apart from diverting resources, this was a time of extreme repression:

People were being shot in the streets. People were being arrested on sight $[\ldots .$.$] These areas were under very heavy occupation and people were living$ underground. So there was enough to be getting on with and those of us who wanted to try and build some sort of a popular movement, it was very difficult to do. (Adams, quoted in O'Hearn 2006, p. 235)

Once the 'no-wash protest' began, a public campaign was more important than ever. Hughes and Sands knew that it was important to feed information to outside supporters. The first move was to create a communications infrastructure by smuggling messages through visits, to give supporters information on which to build a campaign. 
They were helped by fortuitous incidents. After visiting the H-Blocks, Irish Archbishop (later Cardinal) Tomas Ó Fiaich made a highly publicized speech in which he compared the conditions of the blanketmen to the 'sewers of Calcutta'. In October 1978, the blanketmen hit international headlines when US syndicated columnist Jack Anderson compared the H-Blocks to 'the most barbarous regimes of Communist commissars or tinhorn Latin American dictators' (Clark 1987: 96). Then, Frank Maguire, an independent member of British parliament from Fermanagh-Tyrone, visited the H-Blocks and spoke out against conditions there. Activists in the United States and Europe heard about the blanketmen and organized support among trade unionists, politicians, and intellectuals.

Mostly, the blanketmen required mass publicity in Ireland and Britain. For this, the movement had to get on board. Bobby Sands wrote a letter to the IRA leadership. 'As you know', he wrote, 'we have failed to reach a broader base of support, therefore we have failed to engage any active support outside of our immediate hardcore, friends, relatives, etc.'. He called on the movement for more support, saying that they could not survive unless the prisoners won their struggle. Using the analogy of the 'breaker's yard' where prisoners were once consigned to break stones day after day, he said, 'We cannot allow the Brits to turn the H-Blocks into the breaker's yard for the Republican struggle.'

Movement attitudes began to change after Gerry Adams was charged with IRA membership and held in the H-Blocks until he was released due to lack of evidence. He observed the horrid conditions in the H-Blocks and, on his release, he lobbied Sinn Féin to give a higher profile to the prison campaign. According to Adams, the movement then,

started to handle [the prison protest] better, motivated I think by two concerns; one was a genuine concern for the plight of the people in there and the other one was to illustrate to the world and to our own people that here was a manifestation of British rule. (Adams, quoted in O'Hearn 2006, p. 235)

Sands and Hughes were not long in testing the movement. Sands led a discussion in his H-Block about mobilizing publicity. He sent a series of comms to the republican leadership in which he outlined an ambitious plan $^{6}$ : The idea to reach people is to pass a simple message to them [...] "Smash H-Block" [...] We want to get this message to everyone, we want to

6 The comm from which the following quotes are taken was from 'Marcella' to the 'Republican Leadership', see O'Hearn (2006: 237-241). 
make it impossible for people to forget it, no matter who they are or where they are, they shall see it, hear it. Sands said that, 'we must create our own mass media' through direct action.

In one weekend we move and distribute one million posters [...] [W] stick them everywhere on roads, bridges, walls, trees, windows [...] [W]e must work on people to get them to put them up, we must put them on everything that moves to carry them for us, at traffic lights we stick them on vehicles, they'll be carried into towns [...] By doing this we create our own mass media.

Sands was certain they could win mass support if they kept hammering away at people. Supporters should

give our material and put our case, emotionally breaking people down into giving a commitment, put them on the spot there and then, offer them ways in which they can help [...] By continuing pushing 'Smash H-Block' we believe we are pushing a small message and making people aware through their wee jobs and those who they reach will learn something if it's only that H-Block exists. They will help and support. We'll pick up as we progress!!

Sands summarized his campaign in four simple steps:

1 Organize the people that we have already got.

2 Attack through mass media propaganda, through an army of propagandists, you out there and we in here [...]

3 Make our message simple - 'Smash H-Block', some details, a call for action, plenty of emotion.

4 Broaden our battlefield, locally, nationally, and internationally, the field is limitless.

But the blanketmen needed resources.

We need a list of names, a who's who, what's what in Ireland, all those who have influence, here's a few to start with, trade unions [...] social conscious groups, left wing groups, churchmen Catholic and Prod, with influence, newspaper and tv and media list of people who write or produce political or social programmes and articles, etc. Anybody who's anybody [...] The idea is this, one of us in here can write to one of those above or whoever, in a very emotional and distressing letter. 
To create 'an atmosphere of mass emotion' Sands suggested a

Poster with a child on it, emotional The Year of the Child 'Don't Let my Daddy Die in H-Block' [...] Get those 'Smash H-Block' posters up everywhere [...] Paint 'Smash H-Block' all over the major motorways in Britain [... ] We want H-Block more common than Shamrock and we can do it.

Finally, Sands suggested chain letters, pirate radio stations, school boycotts, industrial strikes, demos at sporting events, an H-Block flag, and an International Committee headed up by a team of sympathetic priests.

Over the following months many of these suggestions were enacted. A National H-Block/Armagh Committee was launched with its campaign centred on the simple message, 'Smash H-Block'. Within months that slogan appeared on walls, bridges, and hoardings across Ireland. Posters did appear with the slogan 'Don't Let My Daddy Die in H-Block'. And Sands organized a 'factory' where the blanketmen wrote hundreds of letters each week to practically anyone with any kind of influence.

This factory required raw materials: writing supplies, addresses, and other information. Sands organized the prison side while women from Sinn Féin coordinated a team of young women who visited the prison twice a day, smuggling messages and supplies. Sands could send out messages in the morning and receive replies from the movement that afternoon.

Smuggling involved kissing prisoners who were filthy, had not brushed their teeth for years, to get communications that had been in all parts of their bodies. The women did things that went against much they had been taught about the purity of their bodies. They had to secrete comms, supplies, and even miniature radios and cameras in their own bodies. Despite the ordeal, day after day, month after month, they kept up their visits.

Comms going out of the prison described conditions in the H-blocks. A designated prisoner on each wing of each H-Block gave his blanketmen lists of names and addresses. They each wrote four or five letters a day, based on sample letters that explained the conditions in the H-Blocks and why they had been forced into the no-wash protest. Each letter contained a personalized message. As time went on, templates were customized for different readers. One prisoner wrote a US journalist about how his founding fathers had fought the British for independence and the Irish had as much right to fight. Then he wrote to a 'comrade' in Pravda about the working-class struggle against imperialism. Personalized letters from blanketmen went to celebrities such as Muhammad Ali and Jean-Paul Sartre. 
While communication was important, prisoners also used 'mis'communication to invert movement power structures to their advantage. One incident happened after guards told the prisoners that they would begin washing them forcibly. They would start the forced washings among YPs, knowing that if they could break YPs, others would follow. Hughes and Sands thought the forced washings could involve violent scrubbing and prisoners could be injured. They decided to order the YPs to 'resist'. Sands shouted the order to the block that contained most YPs. The OC of that block, however, feared that resisting would be bloody and disastrous. Moreover, the young men were afraid and might refuse to resist. That would hurt morale and might even endanger the whole blanket protest. So the OC 'did not hear' Sands' order and the YPs went peacefully to the washings without losing face.

Another incident occurred between the first (1980) and second (1981) hunger strikes. During this period the IRA leadership ordered blanketmen in two H-Blocks to abandon their protest, to see if the prison authorities would deliver their own clothes to them. On a Friday, families arrived at Long Kesh with packages of clothes. On Sunday, Sands informed the movement that if they did not have their clothes by Tuesday night they would smash their furniture. The IRA frantically sent comms to Sands through a priest, instructing him to call off the action. Sands got the comms but he did not call off the protest.

'The sagart [priest] didn't appear', he wrote the movement as an excuse after the prisoners smashed their furniture.

Sands wanted to send a clear signal to his own superiors that he 'meant business'. He also wanted to put them into a clear frame of action for a new hunger strike. The movement thought smashing furniture would start a transition back into the no-wash protest, but the prisoners meant it as a prelude to a new hunger strike. The IRA was so opposed to the second hunger strike that they did not realize how far into that strategy the prisoners had already moved. On Tuesday the blanketmen trashed their cells. A month later they were on a hunger strike in which ten men including Bobby Sands would die. Control of communications allowed subservient prisoner leaders to 'not hear' their IRA superiors, just as the OC in the YP's block 'did not hear' Sands' order to resist forced washings.

\section{Discussion}

Prison, even cellular isolation, is about movement: through spaces and movement in the sense of organized action aimed at achieving change. 
Effective movement requires solidary purpose, clear goals, and strategies to strengthen collective identity (Gamson 1992). The bare life conditions in the H-Blocks, where the community shared resistance and a daily experience of intersubjective communication and collective joy, strengthened them against oppressive actions of authorities (O'Hearn 2009).

But the collective also required connections to outside networks for material needs and public support. This was difficult since their 'natural' allies (their movement) were initially unwilling to help build a sustained campaign. The degree to which prisoners swayed the minds of key leaders in the movement was remarkable, as was their ability to provide information (propaganda) for the campaign and even direct its tactics (down to slogans and poster content).

De Vito's model connecting inside-outside movement relations to prisoner radicalization ${ }^{7}$ is of limited use here. He relates the 'peak' of European prison radicalization in the early 1970 s to heightened awareness of the connections between the social function of prisons and inequality in society - what Wacquant (2009) would later call 'punishing the poor'. This enabled Marxist prisoners to see others as oppressed proletarians rather than lumpenproletarians and thus make common cause with them (De Vito 2012: 78). This model does not really apply well to national liberation movements, a fact De Vito later admits when discussing political prisoners in the later 1970s.

IRA prisoners brought their movement practices into prison by resisting 'British/Protestant rule' there and by prefiguratively building a sort of utopian society in the cages and $\mathrm{H}$-Blocks. The need to restructure relations with the movement arose in the H-Blocks because of the special needs of the blanketmen. Prisoners won their case to get more resources on the grounds that an active public campaign around prison issues could revitalize the movement. If there was radicalization of prisoners, it was primarily about deepening their consciousness about why they were in struggle, a process that was enabled less by inside-outside relations than by the prisoners' intense close proximity to each other, without the usual distractions of consumerist life. In the case of the IRA, the movement was largely rebuilt from within the prison in 1974-1976, again in 1978-1981, and yet again in the late 1980s-1990s (McKeown 2001). Political prisoners brought into prison

7 De Vito defines radicalization as 'a shift in the contents and/or forms of contention that, in relation to previous contents and/or forms of contention, is perceived as an escalation by (some) historical agents and/or by external observers' (2012: 72). It is mainly informed by prisoners/ movements in a European context. 
an experience of active resistance and brought back out a spirit of intense community-building, horizontal/participative practice, and communal risk-taking. Such community-building was necessary if 'radicalization', in De Vito's sense of escalated activity, was to be attained.

The actual logistics of escalation raises issues of leadership and space. Some distinguish between 'task-oriented' and 'people-oriented' leadership, between bureaucrats and charismatics. The former 'get things done' while the latter 'reshape their followers' interpretations of the world and emotional responses to it' (Aminzade, Goldstone, and Perry 2001: 130; also Nepstad and Bob 2006). The H-Block protest indicates that such distinctions may be limited. As O'Hearn (2009: 502) proposes, '[i]n intense episodes of contention, it may be precisely the charismatic ability to motivate people into action that "gets things done"'. Certain leaders are particularly sensitive to the needs and potentialities of collective change in a changing environment. They are good at what Goldstone (1991) calls 'process tracing', the ability to guide rapidly changing processes towards desired outcomes.

Process tracing happens in and through space; not simple Cartesian spaces (like football fields upon which the game of contention is played) but socially constructed spaces that have contested and constantly changing uses and meanings (Harvey 1969, 1973; Massey 1994). Spaces are appropriated and mobilized by insurgents as material and symbolic resources, and defended by the powers-that-be as spaces of authority to be kept out of the hands of insurgents. Sewell (2001: 55) refers to spatial agency as the ability of groups to transform and restructure meanings, uses, and the strategic value of space through struggle. Even if, as Sewell contends, insurgents are resource poor in traditional senses, the H-Block struggle shows that prisoners may have an abundance of generally unrecognized resources like solidarity and transformative vision that enable them to use spaces in new and creative ways. In the H-Blocks, while authorities imposed massive mechanisms of physical control, blanketmen changed meanings and uses of prison spaces to gain material needs and change symbolic perceptions of what prison was, including a massive publicity campaign that moulded the public perception of practices like strip-searches as oppression rather than control.

A key advantage of authorities is their capacity to manage the problem of 'time-distance': getting messages from one place to another. They manage what Scott (2009) calls the 'friction of space'. Although the prison authorities had tremendous advantages in time-distance technologies, the blanketmen built rival communications networks that overcame them.

One final form of movement should be explored: movement of experiences across time and space. On the policy side, a clear thread runs from 
the H-Blocks (1976-1981), to US Security Housing Units (SHUs) and supermax prisons (1983-today), to Turkish F-type prisons (2000-today) and Guantanamo. In Turkey we even have a 'smoking gun': Gordon Lakes, Britain's top prison securocrat, advised the Turkish government about avoiding the mistakes of the H-Blocks and publicly intervened in support of introducing F-type isolation (O'Hearn 2013).

Prisoners also learn from each other. While the Irish hunger strikes of 1980/81 were going on, prisoners in Robben Island, Diyarbakir (Kurdistan), and Chiapas (Mexico) followed the Irish hunger strike example. Political prisoners in Turkey and the Basque Country followed. More profound was the movement of the blanketmen's strategies of community-building and resistance, even to accused 'gang leaders' in US prisons. In Ohio, California, and Illinois movements of solidarity leading to hunger strikes were heavily influenced by studying the blanket protest. In Pelican Bay SHU, Latinos, African-Americans, and white prisoners joined together to form a 'Short Corridor Collective'. They shared experiences and discussed texts on left politics, Mayan culture and Irish blanketmen (Ashker 2013). The collective built shared, orally based practices that crossed racial barriers; constructed networks to other prisons and outside supporters, trying to overcome timedistance disadvantages; began using the media to publicize the nature of solitary confinement in California and the United States; organized a hunger strike with more than 30,00o prisoner participants; and eventually forced the California legislature and the prison authorities to change their isolation policies.

As IRA prisoners changed the republican movement from inside the prison, the Short Corridor Collective launched a successful initiative to stop racially motivated prisoner-on-prisoner violence by gangs in California jails and to stop gangbanging by youth gangs in California's urban ghettos. The bare life experience of the SHU, combined with knowledge gained from the H-Blocks and perceptive leadership by a small group of prisoners placed in close proximity, produced a movement for change that was unthinkable a few years before, in one of the most tightly controlled prisons in world history. ${ }^{8}$

Yet a little learning can also be a harmful thing. Leftist prisoners used the blanketmen's experience as guidance for their own hunger strike against the Turkish state's forcible move from open ward-style prisons to cellular isolation in new F-type prisons. On the surface, it looked the same as the British move from the cages to the H-Blocks. From 2000 to 2007, more 
than 120 prisoners and their supporters died on hunger strike. Unlike prisoners in California, however, the Turkish prisoners missed a series of key lessons of the blanket campaign. First, the blanketmen built a strong solidary culture and a powerful support movement, along with a widespread publicity campaign before undertaking the ultimate step of hunger strike. They were assured of mass public support. Turkish prisoners began with hunger strike as a first tactic and never mobilized such support. Second, the blanketmen practiced high participation; no one would be forced to go or stay on hunger strike. The Turkish movement, however, used force and intimidation against its own hunger strikers. Perhaps most crucially, the blanketmen were masters of 'process tracing'; in the no-wash protest as well as the hunger strike they changed tactics as conditions changed. After a few months and ten deaths, the blanketmen stopped their strike and went into new tactics, where they achieved their objectives of regaining control of prison spaces. Turkish prisoners stayed on for seven years, without public support, and even today have no creative strategies for fighting the isolation of the F-type prisons.

\section{Conclusions}

The example of the blanketmen in Long Kesh prison continues to influence policymakers and prisoners across space and time. It also has important implications for the study of social movements. It demonstrated that state policies that are meant to isolate prisoners from each other, short of extreme measures of dungeons and wells, are likely to fail. The more prisoners are stripped the more they build a solidary culture. An equally important finding is how difficult it is for authorities to turn prisons into regimes of total confinement. Prisoners always find ways to move. The more they achieve solidarity and begin taking risks for each other, the more ways they find to appropriate spaces for new purposes and to overcome frictions of space that are imposed by authorities. Eventually, they cross prison walls and build networks with movements and supporters. Significantly, not only the H-Blocks but also US supermaxes like Pelican Bay show how prisoners can use moral authority as well as creative strategies to control their interactions with seemingly more 'powerful' outside movements and activists. Prisoners, whether 'political' or not, are not captives of an all-encompassing 'gaze' that turns them into their own jailers. They are potential actors with astonishing flexibility and power of movement. 


\section{Works Cited}

Aminzade, Ronald R, Jack A. Goldstone, and Elizabeth J. Perry. 2001. 'Leadership Dynamics and Dynamics of Contention'. In Silence and Voice in the Study of Contentious Politics, ed. Ronald R. Aminzade, Jack A. Goldstone, Doug McAdam, Elizabeth J. Perry, William H. Sewell, Jr., Sidney Tarrow, and Charles Tilly. Cambridge: Cambridge University Press, 126-154.

Ashker, Todd. 2013. 'A Prisoner's Story from Pelican Bay's SHU: Concrete Windowless Isolation Cells, a California Tale of Evolving Resistance'. Unpublished manuscript.

Clarke, Liam. 1987. Broadening the Battlefield: The H-Blocks and the Rise of Sinn Féin. Dublin: Gill and Macmillan.

De Vito, Christian. 2014. 'Processes of Radicalization and De-Radicalization in Western European Prisons (1965-1986)'. In Dynamics of Political Violence: A Process-oriented Perspective on Radicalization and the Escalation of Political Conflict, edited by L. Bosi, C. Demetriou, and S. Malthaner, 71-91. London: Routledge.

Gamson, William A. 1992. Talking Politics. Cambridge: Cambridge University Press. Goldstone, Jack. 1991. Revolution and Rebellion in the Early Modern World. Berkeley: University of California Press.

Grubačić, Andrej, and Denis O'Hearn. 2016. Living at the Edges of Capitalism: Studies in Exile and Mutual Aid. Berkeley: University of California Press.

Harvey, David. 1969. Explanation in Geography. London: Edward Arnold.

Harvey, David. 1973. Social Justice and the City. Athens: University of Georgia Press.

McKeown, Laurence. 2001. Out of Time: Irish Republican Prisoners Long Kesh, 197220oo. Belfast: Beyond the Pale.

Massey, Doreen. 1994. Space, Place, and Gender. Minneapolis: University of Minnesota Press.

Morris, Aldon, and Cedric Herring. 1987. 'Theory and Research in Social Movements: A Critical Review'. Annual Review of Political Science 2: 137-198.

Nepstad, Sharon, and Clifford Bob. 20o6. 'When Do Leaders Matter? Hypotheses on Leadership Dynamics in Social Movements'. Mobilization 11.1: 1-22.

O'Hearn, Denis. 2006. Nothing but an Unfinished Song: Bobby Sands, the Irish Hunger Striker Who Ignited a Generation. New York: Nation Books.

O'Hearn, Denis. 2009. 'Repression and Solidary Cultures of Resistance: Irish Political Prisoners on Protest'. American Journal of Sociology 115.2: 491-526.

O'Hearn, Denis. 2013. 'Diaspora of Practice: Northern Irish Imprisonment and the Transnational Rise of Cellular Isolation'. Breac 1.1. https://breac.nd.edu/ articles/36998-diaspora-of-practice-northern-irish-imprisonment-and-thetransnational-rise-of-cellular-isolation/. 
O’Hearn, Denis. 2014. 'Hücre tecridi ve mahpus direnişi' Teorik Bakış 4.

Scott, James. 2009. The Art of Not Being Governed: An Anarchist History of Upland Southeast Asia. New Haven, CT: Yale University Press.

Sewell, William, Jr. 2001. 'Space in Contentious Politics'. In Silence and Voice in the

Study of Contentious Politics'. In Silence and Voice in the Study of Contentious Politics, ed. Ronald R. Aminzade, Jack A. Goldstone, Doug McAdam, Elizabeth J. Perry, William H. Sewell, Jr., Sidney Tarrow, and Charles Tilly. Cambridge: Cambridge University Press, 51-89. 


\title{
9 'Mother Ireland, Get Off Our Backs'
}

\author{
Republican Feminist Resistance in the North of Ireland
}

Theresa O'Keefe

\section{Introduction}

Feminist organizing in Northern Ireland garnered international attention in the wake of the peace process that ended the military campaign of the Irish Republican Army (IRA). This process gave birth to the Northern Ireland Women's Coalition, an all-female political party that claimed to span the ethnonational divide between Catholics and Protestants. The Coalition was drenched in the global limelight and heralded as a success for a feminist politics of peace. This particular history of the Troubles has, however, skewed the mapping of feminist organizing in the North as the over-emphasis on the Coalition comes at the expense of a vast array of feminist groups and campaigns. More broadly, the tendency to emphasize the 'bridge-building' politics has led to a dominant narrative of women's organizing in the North that is far from holistic.

Women organizing under the rubric of republicanism offers one such example of an understudied contribution to the feminist landscape. While the roles undertaken by women during the Troubles remain under-examined relative to their male counterparts (McDowell 2008), a limited body of scholarship does try to account for women's involvement in republicanism and the republican armed struggle (Alison 2009; Aretxaga 1997; Bloom 2011; Dowler 1998; Gilmartin 2013; O'Keefe 2013; Sharoni 2001). Despite these contributions, research that analyzes republican women's organizing as feminists is almost non-existent bar a few notable exceptions (Cockburn 1998; Rooney 1995; Roulston 1997). Republican feminist politics are, for the most part, hidden from view. To be sure, icons like Bernadette Devlin McAliskey are easily recognisable as feminist actors within the wider republican movement but how these feminists organized as republican feminists is significantly less celebrated. As a consequence, the contributions of this form of feminist resistance are in danger of being written out of history despite the saturation of scholarship on the Troubles.

This chapter, in the first instance, contributes to the widening of a Northern Irish feminist genealogy as it charts the development, success, and failures of republican feminism - the feminist organizing undertaken 
by those who identify as both feminist and republican. Republican feminism is also situated within a social movement context to reveal the tensions and tribulations that plagued wider feminist organizing during the war. Thus, the chapter also speaks to the ways in which social movements are themselves boundary makers, and how agendas are shaped not just internally but across social movements. In divided societies, where borders are more starkly drawn (Todd et al. 2006), material, symbolic, and physical boundaries serve to encase and shape social movements. Boundary work is more acute in this context and, as such, republican feminism has much to show us about this process, including the constraints and opportunities of agenda setting and movement-building. Relatedly, this research also builds on the question of why actors join high-risk movements as posed by White and Demirel-Pegg (in this volume). Why did women who were not initially republican feel feminism was bettered through republicanism than the women's movement? As Nancy Whittier (2014) documents, feminism comprises many struggles and feminists active in such struggles do so in an array of social movements and not necessarily in the autonomous women's movement, as is the case with republican feminism. Many women, as explored through this chapter, chose to organize as feminists through republicanism not just because they identified with republicanism but also for reasons connected to class, state repression, and the perceived exclusionary nature of the Northern Irish women's movement. This story is meaningful not only for the articulation of difficulties that arise when organizing in a conflict zone; the analysis also offers compelling insight into how collective identification is shaped by both negative and positive relational experiences (Gamson 1995).

The research for this work is part of a larger project on Irish republican feminism and is based on a feminist ethnography that began in 2000 and concluded in 2007. The data in this article consists primarily of 20 qualitative, in-depth, face-to-face interviews with women active within the republican movement during the Troubles. Interviews were obtained through snowballing with the help of two key gatekeepers who are former republican prisoners. Themes covered by the interviews spanned a range of topics from prior political activism, motivations for joining the republican movement (including the IRA), gender roles within the movement, feminism, and relationships with other groups and campaigns. Documentary research and artefact analysis of political party manifestos, pamphlets, murals, and political ephemera are also an integral part of this feminist ethnography. The research suggests that republican feminism was ignited and shaped by a number of key factors. It formed into a coherent, critical feminist project 
that positively impacted the lives of women in working-class republican communities across the North, as well as the wider republican and women's movements.

\section{Republican Feminist Praxis}

Republican feminism is not derived from any written manifesto as such but its presence is strongly felt in the community as well is in more formal political structures. It is a collective identity, fluid and relational (Polletta and Jasper 2001: 298), 'located in action and interaction', formed through relationships as opposed to any identification formed through individual self-conceptions (Whittier 1995: 16; Melucci 1995). Republican feminism has been shaped over time by four key factors: a historical connection between feminism and Irish nationalism, politicization and 'gender awareness' from experiences with gender-based state violence, feminist politicization around prison struggles, and a marginalization of republican women by both the republican movement and the broader women's movement.

Those who identify as republican feminist claim it to be a radical politics flavoured with Marxist/socialist tendencies rooted in the material realities of working-class women. Some depict it as an all-encompassing view that speaks to broader issues of autonomy, equality, and social justice. Republican and lesbian feminist activist Claire Hackett explains the approach best when she defined it as a commitment to 'self-determination':

The concept of self-determination is what best defines republican feminism for me. This concept is perhaps better known for its nationalist than its feminist connotations. Yet, it must be clear that it has meaning for feminist discourse - self-determination as the right and ability to make real choices about our lives: our fertility, our sexuality, childcare, the means to be independent in all the areas in which we are currently denied autonomy and dignity in our various identities as women. (1995:11)

The British occupation of the North is considered to be the main source of women's oppression as it shapes all political, economic, and social structures. The late Mairéad Farrell, perhaps the most illustrious female IRA volunteer, claimed women in the North are doubly oppressed: 'I am oppressed as a woman, and I'm also oppressed as an Irish person. Everyone in this country is oppressed and yet we can only end our oppression as women if we end the oppression of our nation as a whole' (Derry Film and Video Collective 
1988). Farrell also suggested women were not taken seriously as political actors by republicans or wider society due to traditional gender norms, including those rooted in nationalistic tropes. She claimed the republican prisoners in Armagh women's prison felt hampered by societal expectations regarding motherhood and femininity emblematic in the trope of Mother Ireland. Republican feminism can thus be understood as an attempt to disrupt such norms, to say 'Mother Ireland, get off our back [sic]' (Derry Film and Video Collective 1988).

Republican feminism, situated in the context of the broader struggle for an end to British imperialism in Ireland, has taken on many forms of the years. Its origins lie in grass-roots organizing though it quickly bled into the formal political realm as republicanism increasingly engaged in electioneering. Though there have been many groups connected to republican feminism since the start of the Troubles and, as a result, differences abound, at the core of this organizing is a belief that partition has put a particular shape on gender relations on the island of Ireland.

\section{Historical Contexts}

The first factor to give rise to republican feminism was the pre-existing relationship between Irish nationalism and feminism. Feminist nationalist icons active in the 1916 Easter Rising like Constance Markievicz and Helena Moloney continue to serve as role models to most republican women (Ward 1983). While, as Connolly (2003) suggests, the suffragettes had victories independent of the nationalist movement, for many the two struggles were inextricable. Markievicz made clear the relationship between women's position in Irish society and the national question when in 1909 she wrote that the 'first step on the road to freedom is to realise ourselves as Irishwomen - not as Irish or merely as women, but as Irishwomen doubly enslaved and with a double battle to fight' (as cited in Owens 2005: 112). Cumann na mBan's formation in 1914 pronounced the tensions between those who wished to place primacy on the suffragette movement and those who favoured prioritizing the national struggle. Noted suffragette Hanna Sheehy Skeffington felt the women's question was not taken seriously enough within nationalist quarters and registered her disdain for those women who chose to join Cumann na mBan in a letter to the Irish Times denouncing the organization as nothing more than an 'animated collecting box' for men (Owens 2005: 115). Nevertheless, as Diarmaid Ferriter (2004: 218) argues, many women took on multi-dimensional roles that spanned these 
two key movements (Ferriter 2004: 217-218). The visibility and celebration of historic feminist nationalist figures normalized the presence of women and feminist ideas within the republican movement (Sales 1997).

\section{Gendered State Violence and Politicization}

The development of contemporary feminist nationalism though inspired by the actions its foremothers was predominantly instigated through a response to the violence of the British state. When the Troubles erupted in 1968, women were primarily located within the home. With political, economic, and social marginalization of working-class Catholics, the introduction of British soldiers to the streets of the North, and atrocities such as Bloody Sunday, many women became involved in the resistance movement that developed in response to these repressions. The experience of state violence can be considered a 'moral shock' (Jasper 1997) for some respondents insofar as it forced many women to engage in a politics of resistance for the first time in their lives. One republican feminist activist and former IRA member explains:

Growing up in the early seventies [...] there were riots every night, CS gas, Catholics being burnt out of their houses. All this madness was around you daily. I was swept up in what was happening. I joined gCaílní na hÉireann, the junior wing of the IRA, when I was thirteen. Unconsciously I became more politically aware. At sixteen I joined the army. (Interview No. 13)

Similarly, another former IRA volunteer and republican feminist states, 'I grew up in the conflict and war was all around. I gained a political awareness when I was twelve or thirteen and I started asking questions about who is responsible for all of this' (Interview No. 12). These women are 'reluctant guerrillas', a term Jocelyn Viterna uses to describe women who joined revolutionary movements out of necessity (2006: 24), as they felt they were left with no other options but to fight back. This process of politicization is commonly recognized by social movement scholars as symptomatic of the lived experience of hardship and oppression around which grievances and mobilizations are based (Piven and Cloward 1977; Nilsen and Cox 2013).

Republican feminism thus arose, in part, from a process of politicization acquired through engagement in community resistance. Women remarked that their 'increased involvement in political activity gave them a new sense 
of identity'. A former female political prisoner compared the politicization of women in republican communities to the shift in gender roles that took place during the Second World War, particularly in relation to internment when women were left almost entirely to run the communities and the movement as men were in prison or on the run: 'Women took over from the men, everything that they did. But, unlike that [WWII], after internment when the men returned, women stayed there and excelled at things. They didn't go back into the home because men expected them to [...] Nothing's ever been the same since' (Interview No. 5).

Experiences of state violence motivated republican women to engage in a politics of resistance which in turn fostered a 'gender awareness' brought sharply into focus through a realization that the violence of the state was gendered. Because of the gender roles in Irish society, women - women's bodies, in particular - became the interface at which the struggle for power in the North was fought. At that time women were less likely to work outside the home, they brought the children to school, did the shopping during the day and, when internment was first introduced, made up the majority in housing estates as men were either on the run or locked up. Women had to contend with continual house raids and street interrogations by security forces as they carried out their daily routine. In addition, women led the street resistance against the state, forming 'hen patrols' to warn of approaching army patrols, breaking state-imposed curfews, and disrupting everyday army blockades.

While sectarian harassment by security forces was commonplace (McVeigh 1994), women experienced sexual harassment on countless occasions (Pickering 2002: 37). Sexual slurs and jeers at their bodies were often part of the verbal assaults in attempts to sexualize women and make them uncomfortable. In addition to being called a 'slut', 'Irish whore' or 'Provie blanket', references to rape were also made. Such comments were made by soldiers in passing foot patrols, driving Land Rovers, or even standing in watchtowers where women were easily scrutinized (Harris and Healy 2001: $69,85,89$ ). This harassment was so commonplace that women typically considered them normal or 'just the usual' (Interview No. 18).

Sexualized violence and harassment was also found inside detention centres and jails. Sexual overtones, slurs, and actions were frequently used as a means of intimidation during interrogation while some go so far as to suggest multiple cases of 'rape, threats of rape, and technical rape' committed by the army and the RUC in the North (Harris and Healy 2001; McCafferty 1981: 34). More than one interviewee reported experiences with sexual violence at the hands of state forces and their stories ranged from threats of rape to harassment and assault (Interview No. 18; Interview No. 21A; O'Keefe 2013). 
The execution of gender-based state violence is also evident in the stripsearching of female political prisoners, instituted as a regular practice in 1982 (Gillespie 1994: 2). Strip searches were used to target republican women in particular, including those on detention awaiting a court hearing. Women endured strip searches more often than their male counterparts and the searches were often accompanied by the threat of sexual violence or the use of sexually violent language (Pickering 2002). Many who experienced these invasive procedures compared them to rape (POWs in Maghaberry Prison 1986; Aretxaga 1997:24; Aretxaga 2001: 9). Searches were justified as a security measure despite the fact that little contraband was ever unearthed. Both the National Council of Civil Liberties and Amnesty International conducted inquiries into the practice and condemned it as an exercise 'with the deliberate intention of degrading and humiliating women' (as cited in O'Rourke 2013: 76).

Republican women were attuned to the gendered nature of this violence as is shown in former republican prisoner and current Sinn Féin MEP Martina Anderson's statement on her experience: 'The British government is using women's nakedness to tyrannise them. We feel that our bodies are used like a weapon to penalise us with the intention of making us collapse under the pressure' (McAuley 1989: 75). The ability to use a gender lens to examine their experiences of state violence helped to foster a deeper, feminist political awareness. Republican activist Lily Fitzsimmons suggests that 'The British presence unified women in a determination where we organized ourselves against the military repression of the British army. It also made us realize our strength as a group' (Gillespie 1994:12).

\section{Prison Struggles and Acts of Solidarity}

Another factor that contributed to the growth of feminism amongst republican women is the experience of prison struggles either as a prisoner or campaigner on the issue of women's prison conditions. Though related to strip searches and gender-based state violence during detention, time spent in prison is distinctly significant in that it was a fortuitous educational experience. Political incarceration created a space for discussion, learning, and reading about other struggles for social justice. Though Armagh prison did not have formal classes like those offered to men in Long Kesh (McKeown 1999: 9; Interview No. 13) women engaged in self and collective education by means of shared reading and discussions through prison walls. Many of these readings included histories of struggles for equality. 
One former Armagh prisoner states, 'Throughout my life I have always identified with women's rights and equality but throughout jail my whole outlook was broadened [...] The whole range of how I would think and speak is a feminist outlook' (Interview No. 12). Similarly, Mairéad Farrell said of her time in prison: 'Well, we were educating ourselves in there and through events we became more aware of ourselves as women. So the movement developed and has developed over the years as regards to women prisoners and we developed ourselves in there. It was educational for both I think' (Derry Film and Video Collective 1988).

Familiarity with social movement struggles across the globe was commonplace amongst republican activists. Long-standing connections had been made with other movements, including Palestinian solidarity organizing, the anti-apartheid movement in South Africa, and the US Civil Rights Movement. Feminist icons, such as Andrea Dworkin, spoke on the Falls Road, the heart of republican West Belfast while Bernadette Devlin popularized the politics of former Black Panther Angela Davis when she visited her in prison (Interview No. 17). Some feminists outside the North sought to lend their solidarity to the women in prison and many feminists from Britain, Europe, and as far away as the United States and New Zealand joined the pickets organized by republican feminists outside the gates of Armagh prison (D'Arcy 1981; Interview No. 6). These acts of solidarity had a profound effect on the republican women as they resulted in knowledge exchanges and the sharing of feminist ideas. One woman who helped organize the pickets explains:

It was a whole learning process [...] A lot of the women who came over to help were lesbians and it was free and open [...] They were talking about different things and we realised that we were so ignorant and we decided we should read about women's bodies, so I read Our Bodies, Our Selves. I was reading it and thought, 'I didn't have a clue'. Once you broke out of your shell you wanted to know everything. (Interview No. 5)

Thus, for those women who spent time in prison or organized on the condition of women prisoners, their experiences helped foster an appreciation and commitment to feminism issues.

\section{Marginalization}

Finally, republican feminism was fostered through the experiences of marginalization and disempowerment many women felt inside both the 
republican movement and the broader Northern Irish women's movement. Studies concerning other cases of feminist organizing highlight the importance of boundary work or oppositional identification to the framing of particular feminist collective identities (Taylor and Whittier 1992; Roth 2008; Rupp and Taylor 1999). Kimberly Springer (2005) details the significance of oppositional conflict in collective identity formation to Black feminist struggle. Relating to both Black men active in the struggle for Black liberation and white women in the women's liberation movement was an integral part of the process of politicization and group definition for Black feminism. This relational process resonates with the development of republican feminism in that oppositional conflict within and across both the nationalist and women's movement was also part of the process of republican feminist collectivization.

Gender divisions were clearly evident within the IRA, for instance, as women initially had to fight to be admitted in to the organization. Prior to the early 1970s, women were relegated to auxiliary roles as part of Cumann na mBan. This changed when women demanded military training from a new IRA leadership (Interview No. 11; Interview No. 13).

According to a number of the women I interviewed, men did have difficulty when women joined the army initially, while others insisted they had to engage in a more sustained struggle for equality. 'They had to fight for it', one former volunteer explains. 'A lot of the women that were involved had to fight for their position and certainly Marian Coyle and Rita O'Hare even had to fight to be a volunteer, you know, because we were just supposed to be making the tea or whatever' (Interview No. 21A).

Once within the IRA women took on key roles like bomb-making and training but their work in combat was not reflected in the organizational structure of the Army. One former female IRA volunteer states:

They still only have second-class status. They would not be in top-ranking positions and that is all across the board, North and South [...] Over the past 30 years you might find five [women at a high level within the leadership of the IRA] [...] Men make all the important decisions. Generally speaking, the Army Council is men and maybe a token woman [...] Men are there because they are men; women have to earn their place because they're women. (Interview No. 7)

This gendered divide is made clearer when looking at the peace process and the limited role afforded to women over the course of the negotiations. Republican women were angry at their exclusion and publicly called on the 
leadership to rectify their marginalization (Falls Women’s Centre 1995; Clár na mBan 1994: 15).

The exclusion of women from these formal structures is not the only indication of the unequal status of women relative to men within the movement. Women's participation in the republican armed struggle is not given the same prominence as that of their male comrades. Hero worship in the form of ballads, poems, murals, and memorabilia are overwhelmingly dedicated to male volunteers (O'Keefe, 2013; McDowell, 2008; Dowler 1998). So explicit is this 'exorcism', as Martina Anderson termed it (Anderson 2001), that women organized their own collective memory work to ensure their place within the movement's history is documented (see, for example, Brady et al. 2011; Falls Women's Centre 1995).

Republican feminism as a collective identity was also shaped and consolidated by the marginalization of republican women from the broader women's movement in the North. Republican women were blamed for the tensions and subsequent under-development of the movement. Monica McWilliams of the Northern Ireland Women's Coalition, the Northern Ireland Women's Rights Movement, and the Downtown Women's Centre writes: 'Regardless of the differences between some of the groups, the dominant voice within the women's movement in Northern Ireland has been that of the various shades of nationalism. Giving top priority to the nationalist question served to silence the voices of Protestant women' (McWilliams 1995: 27; McWilliams 1991: 94).

Many within the movement emphasized the importance of bridgebuilding and felt it necessary to focus on universality rather than difference. A 'check your label at the door' policy was adopted for a number of meetings, and, most notably, as general policy for the largest group - the Northern Ireland Women's Rights Movement. This 'lowest common denominator politics' (O'Keefe 2013) meant that women attending meetings were not allowed to raise issues that were not shared by all women. It silenced those who wished to talk about experiences of oppression as, for example, gay women, working-class women, or republican woman.

This lowest common denominator politics meant that republican women were not allowed, for instance, to discuss the most pressing issues in their lives, namely, the violence of the state. Claire Hackett, a self-described republican feminist and queer activist, says:

There were no concerted efforts on behalf of the women's movement to address [state violence against women]. It came from women organising within the republican communities [...] The daily state harassment wasn't articulated as a gender issue but a republican issue [...] They didn't deal 
with it because they would have had to take up a position themselves on the state and that was too scary. (Interview No. 14)

This policy, therefore, ignored the daily material realities of most women living in the North (Roulston 1997). It obscured the conflict and its affects on women, particularly women in working-class areas.

The campaign for the rights and dignity of female republican prisoners was particularly contentious for the women's movement. As strip searches were implemented, republican women pleaded with the broader women's movement for support (Loughran 1985; McCafferty 1980). Rather than condemning gendered state violence, many groups gave these women the cold shoulder, leaving them to organize on their own or with the support of women outside of the North.

More contemporary women's organizations (such as the Northern Ireland Women's Coalition) continued to anchor their politics on the assumption that overcoming 'tribalism' and encouraging communities to get along would resolve the political and structural issues in the North. Like their predecessors, the Coalition refused to take a position on state violence and argued 'politics is about getting on with people [...] [and] moving beyond the often destructive divisions of the past' (Northern Ireland Women's Coalition 2001:1).

This marginalization shaped republican feminism insofar as it encouraged a reflexive approach to dialogues around difference (Cockburn 1998). It also created a space for republican women to organize with other women isolated by lowest common denominator politics (Interview No. 2). For example, lesbian feminists were also silenced by this approach as issues pertaining to sexual orientation were deemed divisive and 'putting off ordinary women' (Interview No. 17; Interview No. 14). A strong relationship between republican and lesbian feminist communities developed as a result of their shared marginalization. Some within the lesbian community even chose to put their faith in republicanism to struggle for LGBTQ equality (Hackett 2001; Interview No. 17; Interview No. 9; Interview No. 14). The collaboration and solidarity that developed helped shape republican feminism insofar as it made it more inclusive and meant LGBTQ issues were incorporated into republican feminist politics.

\section{Republican Feminism in Practice}

Republican feminism sought to link patriarchal violence of the state to that which occurred in the bedroom. Republican feminists were active in 
naming and resisting state violence and also in challenging violence against women in the community. They positioned their work at the intersection of capitalism, imperialism, and patriarchy. Examples of what constitutes republican feminism in practice are best found in Women Against Imperialism, the Falls Women's Centre, Sinn Féin Women's Department, and Clár na mBan, all of which made tangible challenges to gender inequality in the North.

Women Against Imperialism (WAI) formed in 1978 the wake of a series of splits in the broader women's movement in the six counties. It was made up of working-class women from republican communities in Belfast and Derry who wished to organize against the violence of the British state and to simultaneously challenge inequality on a number of fronts. According to founding member Una Ní Mhearain, WAI 'took the view that imperialism had distorted all the landscapes within Ireland, all the personal landscapes and political landscapes' (Interview No. 9). WAI is best known for leading the pickets outside the gates of Armagh prison during the no-wash strike. This small group of women gave talks in pubs and clubs on the topic of domestic violence in republican households for which they received a lot of criticism and outrage (Interview No. 9). Una Ní Mhearain suggests these talks had an effect on women in the community: 'An awful lot of women actually made the links as well when we were doing those talks. And it allowed, I think, it allowed women to come together and start to mention those things and start to mention violence, "yeah it does exist in this community"' (Northern Visions Television 2009). WAI members were also critical to bringing an end to the IRA practice of tarring and feathering. Women were tied to a lamp post in plain view and literally tarred and feathered as punishment for 'fraternizing' with British soldiers (Interview No. 9). These women also mobilized around debt, poverty, and living conditions (Interview No. 9). The group lasted until 1981, but many of its members continued to be active across a range of campaigns and organizations.

After WAI disbanded some members, including Una Ní Mhearain, founded the Falls Women's Centre. The centre became a vital support and resource for women in republican West Belfast. It opened its doors in 1981 and sought to provide a safe space for women in the community to be able to discuss and organize around all issues, including abortion, domestic violence, and poverty. The leaflets advertising the centre asked, 'Do you need help, support, advice with marital problems, D.H.S.S., assault, rape, incest or housing queries?' (Northern Visions Television 2009). The centre's volunteers (and, later on, paid staff) accompanied women to the courts, 
to see solicitors when their marriage was breaking down, or to banks and debt collectors, if in financial crisis. They also escorted many frightened women to Women's Aid and removed them and their children from danger if they were being abused. In addition to being a women-only drop-in centre that served as a space for women to meet and chat, it provided classes on subjects ranging from computer training to confidence-building. With an on-site crèche, this made education a reality for many women (Interview No. 9).

The Falls Road was a community not served by the police, so for many women the centre was the only line of defence between them and the husbands who were battering them. Like other women's centres that subsequently popped up in West Belfast, the Falls Women's Centre offered much-needed services and support to working-class women who did not have access to traditional supports. Advice was offered on taboo subjects like pregnancy and childbirth as well as abortion and contraception, significant as abortion was illegal and access to contraception was limited (Interview No. 9). The establishment of the centre was a major achievement for republican feminism as it improved the material realities of many women and helped forge feminist connections between them.

Sinn Féin Women's Department is another example of republican feminism in practice. Operational in 1980, its purpose was to ensure women had a political voice within the party and in its 'ballot box' politics. It sought to affect party policy and introduce women-friendly structures in addition to raising key concerns for women. This was done using more formal party mechanisms as well as through regular publications such as Women in Struggle, a series of manifestos and policy documents. Its first comprehensive policy document was introduced and adopted by Sinn Féin at its 1980 Ard Fheis. The department highlighted issues of importance not just in relation to the republican struggle, like strip searches or the conditions of women prisoners. It also broke the silence on issues like abortion, contraception access, childcare, divorce, and domestic violence. The department is also responsible for Sinn Féin's quota system, which ensures 25 per cent of positions on its Ard Comhairle (Executive Committee) are reserved for women. The department also had the party commit to placing female candidates in winnable seats during elections (Interview No. 2; Ward 2000: 7; Rooney 1995: 52).

Due to pressure from the Women's Department, Sinn Féin introduced an educational process for its members on domestic violence (A Woman's Voice 1988; De Rossa 1998). Childcare subsidies were also introduced for 
Sinn Féin's female employees (Lyons 1992: 267). Una Ní Mhearain of the Falls Women's Centre explains: 'Women have fought very long and hard to have those policies brought in and to shape policy' (Interview No. 9). Despite these achievements, the Women's Department failed to secure a pro-choice position from the party, much to the disappointment and anger of many republican women. Though the Women's Department no longer exists, the issue of reproductive choice continues to be a thorn in the side of the party as republican feminists place pressure on the party from the inside to adopt a feminist, pro-choice stance (Lane 1998).

Clár na mBan is another important example of republican feminist mobilization. Based on a series of informal conversations about the future of women in Irish nationalism, Clár na mBan officially formed in 1994 in the wake of the ongoing Hume-Adams talks. The group consisted of many established republican feminists like Claire Hackett and Una Ní Mhearain and sought to bring republican women together to discuss what a new Northern Irish society might look like. Clár na mBan was committed to ensuring that the voices of working-class women were heard when it came to shaping the future and in that vein organized a Belfast conference in March 1994 entitled 'Clár na mBan' (Irish for 'Women's Agenda for Peace'). The conference heard from many prominent republican feminists, such as Bernadette Devlin McAliskey, who denounced the ongoing peace talks: 'I reject the Hume-Adams agreement for the very simple reason, I haven't seen it' (Clár na mBan 1994: 15). There was a shared concern that the new society promised through the peace process would mean business as usual for women: '[W] hen the [British] government are talking about guaranteeing an end to violence, they are talking about the IRA handing over the weapons [...] they are not talking about making it a criminal offence for a man to beat his wife' (Clár na mBan 1994:15). The agenda put forward as a result of the conference called for a 'demilitarised society, economic equality, rights for children, and an end to discrimination against disabled people and lesbians' (Clár na mBan 1994: 15). These proposals were submitted to the Forum for Peace and Reconciliation and also helped to shape the equality measures introduced in the Good Friday Agreement (Rooney 2000: 172; Interview No. 14).

These four examples expose the reach of republican feminism across both grass-roots and institutional levels. They also provide a snapshot of the shape republican feminism has taken as the Troubles progressed over time and as different issues came into focus. While the richness of this approach is evident throughout the conflict, the same cannot be said as the movement transitioned away from armed struggle. 


\section{Republican Feminism after the Good Friday Agreement}

In the aftermath of the Good Friday Agreement republican feminism bears little resemblance to its early manifestations. This, in part, can be blamed on the institutionalization of republicanism as Sinn Féin strives for all-Ireland electoral success. The Women's Department was replaced by an Equality Department and manifestos dedicated solely to gender concerns are no longer issued. Feminists are still active within the party though are much less visible as a collective entity now.

Republican feminists are still active at the community level though in a manner that is more dispersed and less obvious. With funding for many community groups coming from EU Peace and Reconciliation Funds, many are forced to emphasize peace-building initiatives rather than decidedly feminist projects (Women's Support Network 2004: 7; O'Dowd et al. 2006). The Falls Women's Centre still exists, however, even though its founding members have moved on to other things. It offers much the same services as when it first opened the doors and these are greatly expanded and professionalized. It remains a feminist stalwart in republican West Belfast, drawing in younger generations to avail of its educational and social offerings.

While the heyday of republican feminism may have passed its significance it should not be discounted, as the lives of many women improved as a result of the collective organizing done in its name. It is, therefore, important that it is included in any documentation of the history of struggles for equality and social justice in the North. More broadly, there are lessons to be learned from republican feminism. Its development tells a story of how feminism can grow in extraordinary circumstances, how it can be made meaningful, how it is contradictory, and how it can affect change even in the face of treacherous conditions. Social movement scholars can draw on this case as an example of the significance of relational processes leading to collectivization and collective identity formation. Feminist activists and academics too, can use it to understand the complexities of organizing in divided societies. It serves as a reminder for feminists to be cognizant of the pitfalls of failing to adopt an intersectional approach to building inclusive feminist politics. The republican feminist case also serves as a useful critique of universal sisterhood insofar as it shows why the construction of difference is as important as notions of universality when organising as feminists. Finally, the story of republican feminism reminds us of the importance of reflexive feminism grounded in the everyday lives of women, of ensuring feminism is relevant and reflective of 'where we live, in our present' (hooks 2000: 117). 


\section{Interviews}

No. 2, 12 September 2000

No. 5,16 October 2000

No. 6, 17 October 2000

No. 7,18 October 2000

No. 9, with Una Ní Mhearain, 23 October 2000

No. 11, 30 October 2000

No. 12, 1 November 2000

No. 13, 1 November 2000

No. 14, with Claire Hackett, 7 November 2000

No. 17, with Maggie Feeley, 30 August 2005

No. 18, 4 August 2009

No. 21A, 23 February 2010

\section{Works Cited}

Alison, Miranda. 2009. Women and Political Violence: Female Combatants in Ethnonational Conflict. London: Routledge.

Anderson, Martina. 2001. 'Lessons of Irish Hunger Strikes'. Speech delivered to a Bloody Sunday Meeting, 27 January. Bloody Sunday Weekend Centre, Derry.

Aretxaga, Begoña. 1997. Shattering Silence: Women, Nationalism, and Political Subjectivity in Northern Ireland. Princeton: Princeton University Press.

Aretxaga, Begoña. 2001. 'The Sexual Games of the Body Politic: Fantasy and State Violence in Northern Ireland'. Culture, Medicine and Psychiatry 25.1: 1-27.

A Woman's Voice. 1988. 'Domestic Violence: Stop It Now'. A Woman's Voice 2 (September).

Bean, Kevin. 2008. The New Politics of Sinn Féin. Liverpool: Liverpool University Press.

Bloom, Mia. 2011. Bombshell: The Many Faces of Women Terrorists. Toronto:Penguin.

Brady, Evelyn, Rosie Hamill, Pauline Jackson, Kate McKinney, and Eva Patterson, eds. 2011. In the Footsteps of Anne: Stories of Republican Women Ex-prisoners. Belfast: Shannaway Press.

Clár na mBan. 1994. ‘Clár na mBan/Women's Agenda for Peace.' Conference Report. Belfast: Clár na mBan.

Cockburn, C.1998. The Space between Us:Negotiating Gender and National Identities in Conflict. London: Zed Books.

Connolly, Cynthia. 1995. 'Ourselves Alone? Clár na mBan Conference Report'. Feminist Review 50: 118-126. 
Connolly, Linda. 2003. The Irish Women's Movement:From Revolution to Devolution. Dublin: Lilliput Press.

Cowell-Meyers, Kimberly. 2011. 'A Collarette on a Donkey: The Northern Ireland Women's Coalition and the Limitations of Contagion Theory'. Political Studies 59: 411-431.

D’Arcy, Margaretta. 1981. Tell Them Everything. London: Pluto Press.

De Rossa, Róisín. 1998. 'Violence against Women - Taking on the Ideology'. An Phoblacht, 7 January.

Derry Film and Video Collective. 1988. 'Mother Ireland'. Video.

Dowler, Lorraine. 1998. "And They Think I'm Just a Nice Old Lady": Women and War in Belfast, Northern Ireland'. Gender, Place and Culture 5.2: 159-176.

English, Richard. 2003. Armed Struggle: The History of the IRA. London: Pan Macmillan.

Falls Women's Centre. 1995. 'What Did You Do in the War Mammy?' Video.

Fearon, Kate. 1999. Women's Work: The Story of the Northern Ireland Women's Coalition. Belfast: Blackstaff Press.

Ferriter, Diarmaid. 2004. The Transformation ofIreland, 1900-200o. London: Profile Books.

Gamson, Joshua. 1995. 'Must Identity Movements Self-Destruct? A Queer Dilemma'. Social Problems 42.3: 390-407.

Gillespie, Una. 1994. 'Women in Struggle, 1969-1994'. Women in Struggle (Sinn Féin Women's Department) 2 (Autumn).

Gilmartin, Niall. 2013. 'Negotiating New Roles: Irish Republican Women and the Politics of Conflict Transformation'. International Feminist Journal of Politics 17: 58-76.

Hackett, Claire. 1995. 'Self-Determination: The Republican Feminist Agenda'. Feminist Review 50 (Summer): 111-116.

Hackett, Claire. 2001. 'Irish Queer and Equal'. Left Republican Review 4 (August): 20-23.

Harris, Helen, and Eileen Healy, eds. 2001. 'Strong about It All': Rural and Urban Women's Experiences of the Security Forces in Northern Ireland. Derry: Northwest Women's/Human Rights Project.

hooks, bell. 2000. Feminism Is for Everybody. Cambridge, MA: South End Press. Jasper, James. 1997. The Art of Moral Protest. Chicago: University of Chicago Press. Lane, Fern. 1998. 'Abortion Policy Unchanged'. An Phoblacht, 23 April. http:// republican-news.org/archive/1998/April23/23abor.html.

Loughran, Christine. 1985. '10 Years of Feminism in Northern Ireland'. Women's News 10 (May): 4.

Lyons, Laura. 1992 "At the End of the Day”: An Interview with Mairead Keane, National Head of Sinn Féin Women's Department'. Boundary 2.19. 
McAuley, Chrissie, ed. 1989. Women in a War Zone: Twenty Years of Resistance. Dublin: Republican Publications.

McCafferty, Nell. 1980. 'It Is My Belief That Armagh Is a Feminist Issue'. Irish Times, 22 August.

McCafferty, Nell. 1981. The Armagh Women. Dublin: Co-op Books.

McDowell, Sara. 2008. 'Commemorating Dead "Men”: Gendering the Past and Present in Post-Conflict Northern Ireland'. Gender, Place and Culture 15.4:335-354.

McKeown, Laurence. 1999. 'Gender and the Social Construction of an Irish Republican Prisoner Community'. Paper presented at the International Studies Association conference, Washington, DC, February.

McVeigh, Robbie. 1994. 'It's Part of Life Here...': The Security Forces and Harassment in Northern Ireland. Belfast: Committee on the Administration of Justice.

McWilliams, Monica. 1991. 'Women in Northern Ireland: An Overview'. In Culture and Politics in Northern Ireland, 1960-199o, ed. Eamonn Hughes. Milton Keyes: Open University Press, 81-100.

McWilliams, Monica. 1995. 'Struggling for Peace and Justice: Reflections on Women's Activism in Northern Ireland'. Journal of Women's History 6.4/7.1: 13-39.

Melucci, Alberto. 1995. 'The Process of Collective Identity'. In Social Movements and Culture, ed. Hank Johnston and Bert Klandermans. Minneapolis: University of Minnesota Press, 41-63.

Moloney, Ed. 2007. The Secret History of the IRA. Toronto: Penguin.

Nilsen, Alf, and Laurence Cox. 2013. 'What Would a Marxist Theory of Social Movements Look Like?' In Marxism and Social Movements, ed. Colin Barker, Laurence Cox, John Krinsky and Alf Nilsen. Boston: Brill, 63-82.

Northern Ireland Women's Coalition. 2001. 'Northern Ireland Local Government Election Manifesto'. Belfast.

Northern Visions Television. 2009. 'Our Generation - Falls Women’s Centre'. Video.

O'Dowd, Liam, Cathal McCall, and Ivo Damkat. 2006. 'Sustaining Cross-border Cooperation: A Cross-sectoral Case Study Approach'. Mapping Frontiers, Plotting Pathways Working Paper No. 11. Institute for British-Irish Studies, University College Dublin/Institute for Governance, Queen's University Belfast. https://www.qub.ac.uk/research-centres/CentreforInternationalBordersResearch/Publications/WorkingPapers/MappingFrontiersworkingpapers/ Filetoupload,175407,en.pdf.

O'Keefe, Theresa. 2013. Feminist Identity Development and Activism in Revolutionary Movements: Unusual Suspects. Basingstoke: Palgrave Macmillan.

O'Rawe, Richard. 2005. Blanketmen: An Untold Story of the H-Block Hunger Strike. Dublin: New Island. 
O'Rourke, Catherine. 2013. Gender Politics in TransitionalJustice. London: Routledge.

Owens, Cullen Rosemary. 2005. A Social History of Women in Ireland, 1870-1970. Dublin: Gill and Macmillan.

Pickering, Sharon. 2002. Women, Policing and Resistance in Northern Ireland. Belfast: Beyond the Pale.

Piven, Frances Fox, and Richard Cloward. 1977. Poor People's Movements: Why They Succeed, How They Fail. New York: Vintage Books.

Polletta, Francesca, and James Jasper. 2001. 'Collective Identity and Social Movements'. Annual Review of Sociology 27.1: 283-305.

Power, Maria, ed. 2011. Building Peace in Northern Ireland. Liverpool: Liverpool University Press.

POWs in Maghaberry Prison. 1986. 'Strip-Searching ... Violence against Women'. Women's News 21.

Rooney, Eilish. 1995. 'Political Division, Practical Alliance: Problems for Women in Conflict'. Journal of Women's History 7.1: 40-48.

Rooney, Eilish. 2000. 'Women in Northern Irish Politics: Difference Matters'. In Gender, Democracy and Inclusion in Northern Ireland, ed. Carmel Roulston and Celine Davies. Basingstoke: Palgrave, 164-186.

Roth, Silke. 2008. 'Dealing with Diversity: The Coalition of Labor Union Women'. In Identity Work in Social Movements, ed. Jo Reger, Daniel Myers, and Rachel Einwohner. Minneapolis: University of Minnesota Press, 213-231.

Roulston, Carmel. 1997. 'Women on the Margin: The Women's Movements in Northern Ireland, 1973-1995’. In Feminist Nationalism, ed. Lois West. New York: Routledge, 41-58.

Rupp, Leila, and Verta Taylor. 1999. 'Forging Feminist Identity in an International Movement: A Collective Identity Approach to Feminism'. Signs:Journal of Women in Culture and Society 24.2: 363-86.

Rynder, Constance. 2002. 'The Origins and Early Years of the Northern Ireland Women's Coalition'. New Hibernia Review 6.1: 44-58.

Sales, Rosemary. 1997. Women Divided: Gender, Religion and Politics in Northern Ireland. London: Routledge.

Sharoni, Simona. 2001. 'Women in Israel-Palestine and the North of Ireland'. In Victims, Perpetrators or Actors: Gender, Armed Conflict and Political Violence, ed. Caroline Moser and Fiona Clark. London: Zed, 85-98.

Springer, Kimberly. 2005. Living for the Revolution: Black Feminist Organizations, 1968-1980. Durham, NC: Duke University Press.

Taylor, Verta, and Nancy Whittier. 1992. 'Collective Identity in Social Movement Communities: Lesbian Feminist Mobilization'. In Frontiers in Social Movement Theory, ed. A.D. Morris and C.M. Mueller. New Haven, CT: Yale University Press, 104-129. 
Todd, Jennifer, Theresa O'Keefe, Natalie Rougier, and Lorenzo Cañás Bottros. 2006. 'Fluid or Frozen? Choice and Change in Ethno-national Identification in Contemporary Northern Ireland'. Nationalism and Ethnic Politics 12.3-4:323-346. Viterna, Jocelyn. 2006. 'Pulled, Pushed, and Persuaded: Explaining Women's Mobilization into the Salvadoran Guerrilla Army'. American Journal of Sociology 112.1: 1-45.

Ward, Margaret. 1983. Unmanageable Revolutionaries: Women and Irish Nationalism. London: Pluto.

Ward, Margaret. 2000. 'The Northern Ireland Assembly and Women: Assessing the Gender Deficit'. Democratic Dialogue, December. http://www.peacewomen.org/ sites/default/files/partpol_northernirelandassemblygenderdeficit_democraticdialogue_dec200o_o.pdf.

Whittier, Nancy. 1995. Feminist Generations: The Persistence of the Radical Women's Movement. Philadelphia: Temple University Press.

Whittier, Nancy. 2014. 'Sustaining Commitment among Radical Feminists'. In The Social Movements Reader: Cases and Concepts, ed. Jeff Goodwin and James M. Jasper. $3^{\text {rd }}$ ed. New York: John Wiley \& Sons, 114-125.

Women's Support Network. 2004. 'A Response to SEUPB Consultation Document "EU Programme for Peace and Reconciliation in Northern Ireland and the Border Regions of Ireland"'. Women's Support Network, Belfast, September. http://www.wsn.org.uk/sites/default/files/consultations/s_sep_04.pdf. 


\section{0 'One Community, Many Faces'}

Non-sectarian Social Movements and Peace-building in

Northern Ireland and Lebanon

John Nagle

\section{Introduction}

Deeply divided societies are those places where ethnicity contains 'permeative propensities' (Horowitz 2000: 7-8) in which virtually all political and social issues align on the dominant ethnonational rather than the socio-economic cleavage. Social movements here play a key role in advancing sectarian interests, fomenting inter-communal antagonism, and even spawning collective violence. Some movements may take to the streets to defend their cultural capital, while others emerge to petition for various group-based rights, or to press for an enlarged share of public goods to be distributed among co-ethnics. In such societies, it is often assumed that there is little space for alternative modes of politics that cross-cut ethnic cleavages. In such discussions, non-sectarian movements are either invisible or rendered as actors that are marginalized, co-opted, stripped of agency, and disempowered. Yet - as this chapter will highlight - non-sectarian social movements in divided societies, like Northern Ireland and Lebanon, represent important forms of mobilization that can even foment policy and social transformation. Such movements include lesbian, gay, bisexual, and transgender (LGBT) groups, environmentalists, trade unionists, housing tenants, the global justice movement, feminists, anti-racists, and peace mobilizations.

In this chapter, I explore the complex forms of mobilization engendered by non-sectarian social movements in Northern Ireland and Lebanon. I ask how these movements contribute to peace-building in the aftermath of inter-communal violence, especially in the context of power-sharing institutions that seek to recognize and accommodate divergent ethnic and ethnonational identities. Such institutional frameworks are critiqued as they supposedly 'close down the space for other ways of being, other ways of being political, other forms of political conflict' (Finlay 2011: 10). Instead of this narrow view, non-sectarian social movements, I argue, force us to question the supposedly isomorphic relationship between ethnicity and conflict in divided societies. Yet, through examining social 
movements, we apprehend the multiple ways in which ethnicity and ethnic groupness is constructed to allow for violent conflict to materialize and how it may be transcended to facilitate peace. Towards this, I note two different types of non-sectarian social movements in Northern Ireland and Lebanon that aim to create change in different ways - transformationist and pluralist movements. While transformationist movements seek to strive to completely transform identities by undermining what they view as a sectarian form of politics that exacerbates ethnic cleavages in divided societies, pluralists seek to force the divided society to recognize and accommodate a greater range of interests and identities that are permitted by a binary, 'either/or' system that reinforces particularistic and antagonistic ethnic politics.

Non-sectarian movements in Northern Ireland and Lebanon can contribute towards political and social change consonant with the goals of sustainable peace-building. Certainly, there are quite obvious ways in which some movements position themselves as fundamental to peacebuilding. Some movements appoint themselves as guardians of peace in the divided society. They take to the streets, for example, to call for the militants to end violence, or hold vigils during peace negotiations, and then mobilize to gather popular support for a peace agreement (see Smithey, in this volume). However, in this chapter, I argue that many non-sectarian movements can support peace-building in extremely complex ways that are, in themselves, not always classified as traditional forms of conflict management. They engage in activities, for instance, to promote equality for LGBT members, to demand better rights for workers, for greater choice for women over reproductive rights, and for better public services. Yet, in calling for these changes, these social movements challenge and unsettle the basic grammar and structure that supports violent separation and the articulation of narrow ethnic interests in the divided society.

Given the strength of ethnic divisions in divided societies, how might non-sectarian social movements provide an alternative? Determining a movement's impact on policymakers requires demonstrating that 'staterelated collective goods would not have appeared in the absence of the movement or specific actions taken by it' (Amenta et al. 2010: 300). Given the number of third parties existing between the movement and the state, the 'principal difficulty is how to establish a causal relationship between a series of events that we can reasonably classify as social movement actions and an observed change in society, be it minor or fundamental, durable or temporary' (Giugni 1998: 373). 
This issue of causality is notably challenging in relation to movements involved in peace-making activities. Hermann (2009) identifies a number of difficulties with assessing peace movements' achievements and failures in Israel. Such movements were interpreted by politicians and ordinary citizens alike as a threat to the national consensus, and sometimes even to national security. The problem of determining social movement outcomes is, I argue, compounded in violently divided societies. Research has demonstrated that the prospects of social movements to influence public policy is bleak when it is closely tied to the national cleavage structure and on which public opinion is very strong (Giugni 2004). The very intensity of ethnic and ethnonational cleavages in divided societies means that practically all issues become points of extreme communal polarization and antagonism. Thus, the mobilization on distributive policies, such as public goods, or over the environment, nuclear weapons, or economic investment, tend to reinforce rather than weaken divisions. Further mitigating the effect of non-sectarian movements is the fact that the state is often weak or highly fractured in divided societies, thus limiting the available political opportunity structure for movements.

If we were to use Gamson's (1990) criteria of 'acceptance' - the capacity of the state to cede to movement requests - then non-sectarian movements in divided societies could claim little evidence of impact. As such, we need to consider different ways to measure the influence of non-sectarian movements. One way to consider this is via Diani's (2000: 391) concept of social movements that create 'intersecting' networks. For Diani, intersecting movements are those that forge relationships which are voluntary, multiple, and overlapping, thereby contributing to the creation of new models of communitarian and organizational action. Such intersecting movements contain relationships that cut across established social and political cleavages. These movements are able to 'draw upon, or generate, new solidarities and group memberships which cut across the boundaries of any specific traditional political cleavage, and thus undermine current forms of encapsulation' (Diani 2000: 399). Diani points to the 'patterns of social relations they generate through the overlapping memberships and personal linkages of their activists, and through the alliances between the different groups which identify with a given cause' (2000: 387 ). Although Diani is not necessarily writing about divided societies, non-sectarian movements, by providing intersecting networks and advancing issues that transcend established sectarian cleavages, provide powerful alternative forms to narrow ethnic politics in divided societies. 


\section{Identity, Consociationalism, and Divided Societies}

Northern Ireland and Lebanon are usually categorized as prototypical examples of deeply divided societies (Kerr 2005). These are places in which the main ethnic groups have mobilized into separate political parties and high levels of residential segregation are prevalent as the main groups live alongside each other in parallel subsocieties' (Horowitz 2000: 6). In divided societies, it is assumed that 'ethnic divisions are resilient rather than rapidly biodegradable, and that they must be recognized rather than wished away' (McGarry and O'Leary 1995: 338). This conceptualization of ethnicity is broadly coterminous with the prevailing explanation of conflict in Lebanon and Northern Ireland (Kerr 2005). In viewing conflict as the product of competing ethnonational or ethnoreligious identities, specific institutions and forms of governance which aim to manage destructive intergroup conflict have been created. In consequence of this understanding of ethnicity, the objective of conflict management is to accommodate the salient, conflicting groups in structures of governance.

This process of accommodation finds fullest expression in consociational forms of ethnic power-sharing. In assuring ethnic minorities some minimum representation in government and influence over policy, including veto power, consociationalism conforms to 'accomodationist strategies' of conflict regulation. By seeking to equally accommodate dual or multiple identities in the polity, consociationalism stands in contrast to centripetal approaches which seek to forge an all-embracing public identity through integration (McGarry and O'Leary 2009).

Consociational power-sharing provides the fundamental point around which conflict management in Northern Ireland and Lebanon rests. Although Lebanon has a long history of power-sharing, consociationalism was recalibrated and reintroduced in 1989 as part of efforts to end the civil war which began in 1975 and led to circa 150,00o deaths. The Lebanese civil war is often portrayed as essentially one between Christians (wishing to preserve their control over the state) and Muslims (seeking to challenge Christian hegemony). In reality, the conflict involved a much greater degree of complexity, encompassing a wide range of external actors, political goals, and high levels of intracommunal fracture. Nevertheless, the signing of the Taif Agreement (1989), which returned consociationalism to Lebanon, primarily sought to revise power-sharing in a way that accommodated the shifting balance of power between Christian and Muslim sects. The agreement's ethos - 'no victor, no vanquished' - signified that no group could exercise dominance over the others within a finely tuned institutional 
apparatus which managed competing group identities (Haddad 2009). Towards this objective, Lebanese power-sharing created an equitable formula in which positions are distributed equally to Muslims and Christians in governance and throughout the public sphere. As part of maintaining this equilibrium, Lebanon's power-sharing is a classic example of 'corporate consociationalism', a form that assumes 'group identities are fixed, and that groups are both internally homogeneous and externally bounded' (McGarry and O'Leary 2007: 675). Group representation is enforced in Lebanon via a quota system which rigidly reserves and allocates executive and legislative positions for the main groups, an arrangement mirrored across the public sector. Until 2009, all citizens had to carry identity cards demarcating ethnic identity in order to apply for public sector jobs.

Consociational power-sharing was introduced to Northern Ireland as part of the Good Friday Agreement (1998). Like the Taif Agreement, the purpose of the consociational agreement was to end violent conflict in the region, which began in 1969, and it also outlined a framework for creating inclusivity in representation between the main groups - nationalists and unionists - as well as institutional roles for the salient external actors, the United Kingdom, and the Republic of Ireland. In contrast to the corporate structure of the Taif Agreement, Northern Ireland's consociational model is celebrated by its proponents for its 'liberal' characteristics; that is, it 'rewards whatever salient political identities emerge in democratic elections' (McGarry and O'Leary 2007: 675). Thus, neither seats nor public positions are reserved for the ethnonational groups in advance of elections. In so doing, proponents argue that liberal consociationalism 'is more likely to transform identities in the long run' (McGarry 2001:124) compared to corporate forms.

While power-sharing is largely recognized as instrumental in ending destructive violence in the two regions, a number of commentators have critiqued both forms of consociationalism for prohibiting a stronger, more enduring peace including intergroup reconciliation. Certainly, one major consequence of the elite level focus of consociationalism in relation to sustainable peace-building is that it typically occludes a range of non-ethnic identity groups that are not institutionally recognized and accommodated. In fact, the de facto process of excluding these identity groups may even have negative consequences for the human rights of individual members. It also fails to include all sectors of society, most especially civil society. Yet, while it is undeniably clear that we need to be careful when crafting institutions to end violent conflict, consociational arrangements may expedite uncertain outcomes some of which are unintended by the architects of these measures. Towards this, this chapter examines the intertwining limitations 
and opportunities afforded by power-sharing and the complex forms of engagement created by non-ethnic movements in response. Power-sharing generates various dynamics that can result in either hegemonic compliance, constructive engagement, or active resistance by social movement actors that cross-cut established ethnic cleavages and who even foment policy and social transformation.

\section{Transformationist Movements}

Transformationist social movements are those that strive to completely transform sectarian identities and politics in the divided society. Transformationist social movements in Northern Ireland are those that strive to completely change a polity dominated by zero-sum ethnonational politics and encourage 'individual actors to transform their social identities into something other than merely Protestant Unionist or Catholic Nationalist' (Edwards 2007: 139-140). An example of this can be seen in class-based movements, which asks citizens to see their common interests as workers rather than as divided ethnicities. In this way, antagonistic ethnic identities will be superseded by unified class encapsulations. One socialist movement campaigns to 'make the class we belong to more important than the community we come from' (Socialist Environmental Alliance 2005).

The main focus of this type of social movement is annual socialist and trade union May Day march through Belfast city centre. The Belfast May Day parade is relevant to the present discussion due to how the event has been reimagined during the peace process as a form of mobilization that embraces ethnic diversity within the broad unity of a class-based movement. Prior to the peace process, in the late 1960s and 1970s, when sectarian violence was its most intense in the city, the May Day organizers fought to provide an image of working-class unity in distinction to the acrimony promulgated by the divisive narratives of ethnonationalism.

The development of the Northern Irish peace process in the 199os provided impetus for the trade union movement to reframe its objectives in terms of diversity enshrined in the aims of the international workers movement and peace-building. Trade unionists use the May Day parade to challenge the competitive nationalisms which contribute to the sedimentation of violence and segregation in Northern Ireland. A May Day organizer told me:

What we have strived to do is to create a safe space for people of all religions and none to come together to mark their relationship as working 
people rather than as Catholics, as Protestants, as atheists, whatever [...] It's a non-sectarian, non-denominational march. (Interview No. 1, 2007)

Another organizer described the annual May Day demonstration thus:

It's a very good thing coming out and saying: 'My identity does not necessarily come from the religion I was born into or my perceived political baggage or my past or my age or my race or my gender or for that matter my sexuality'. What you do when you take part in that May Day parade is that you are expressing $[\ldots]$ solidarity $[\ldots]$ based upon our class and also our common humanity. I think it is quite important that it happens every year in Belfast. (Interview No. 2, 2007)

The diversity of May Day is further expressed through the range of groups who participate: not only trade unions, but also nationalist and unionist groupings traditionally linked to paramilitary organizations (such as Sinn Féin and the Progressive Unionist Party (PUP)), the Anti-Racist Network, the Campaign Against Water Privatization, environmentalists, the Anti-War Coalition, the Northern Irish Gay Rights Association (NIGRA), amongst many others. One of the most successful mobilizations in recent years was in 2005 when 6000 people marched to protest against rising levels of racism and to proclaim solidarity with the city's migrant groupings. The 2003 May Day celebration was described as 'rejecting sectarianism and celebrating diversity in Northern Ireland. Today's parade is seen as one of the few marches in Northern Ireland which has been designed to embrace participation from people of different backgrounds' (Belfast Telegraph 2003). Lebanese transformationists are more direct in seeking to end state-sanctioned sectarianism, such as the use of the ethnic quotas to determine political representation and public positions, and the role of religion in governing public life. These movements may deal with specific aspects of political sectarianism or generate broad-based platforms that encompass a range of interconnected campaigns. Issues advanced by movements focus on civil marriage (Laïque Pride), electoral reform (Take Back Parliament), domestic violence, women's reproductive rights (Nasawiya), LGBT rights (Helem, Meem), and even the introduction of a shared history text for Lebanon's school children (AUB Secular Society). Given the intersectionality of issues these movements engage in, it is often the case that the membership of these movements strongly overlaps.

A good example of a Lebanese Transformationist movement is the 'You Stink' mobilization that emerged in 2015. In July 2015, the power-sharing 
government, stuck in a fierce political deadlock, was unable to renew the contract for the main refuse company to dispose waste in a landfill. As a result, more than 20,00o tonnes of rubbish amassed uncollected in Beirut's streets. In response, a newly formed protest movement - 'You Stink' - gathered tens of thousands of protestors in Beirut city centre to demand the government's resignation for allowing sectarian differences to supersede the public's environmental and health needs. Many protestors - reported as 'people from across the sectarian and political spectrum' (Al Jazeera 2015) - carried placards and symbolic refuse bags and wore paper masks to cover the stench of the trash and what they viewed as the decaying political class.

For You Stink's activists, the incapacity of the state to deliver key public goods is an outcome of the power-sharing system that incentivizes corruption and sectarian conflict. A leading activist explained that the sectarian elites 'are using the confessional system for their corruption, so it is a vicious circle and you have to find a way to stop it' (Interview No. 5, 2016). The You Stink protests, which attracted up to 100,00o participants in Beirut city centre, exposed the level of opposition to how power-sharing has been deployed to legitimate corruption and to diminish the public sector. A You Stink leader argued that the movement represented 'the silent majority that is disenfranchised, but they are not powerless' (Interview No. 6, 2016). In mobilizing these people, You Stink articulated a powerful alternative politics to the sectarianism reproduced by political leaders. You Stink, therefore, connect to 'cognitive liberation': the process through which activists encourage individuals to formalize shared understandings of their situation as one of oppression and marginalization so that they achieve groupness (McAdam 1982). While sectarian politics has typically operated by reproducing ethnic antagonism, You Stink's encourages cross-cleavage alliances and a political sensibility that fosters civic interests. A leader explained:

People are angry in Lebanon and what the politicians do is that they turn this anger towards the sectarian 'other'. What we try to do is redirect the anger at the actual culprits. For once we realise that our economic and our day-to-day anger shouldn't be directed at one another. It should be directed at the people in power and for us to make them accountable. As long as we keep redirecting the anger, this might get the people to forget about their confessional background and go towards the higher goal: a better country for us all [...] There is no such thing as sectarian segregation unless it's in the mind of our politicians. (Interview No. 6, 2016) 
Rejecting the status of marginalized and disempowered actors that are unable to affect social and policy change in the context of a monolithic sectarian structure, You Stink activists see the protests as fomenting significant opposition to a form of political sectarianism that incentivizes ethnic antagonism, corruption, and dysfunctional political institutions. For a You Stink leader, an important achievement of the movement is to break the 'godlike' stature of the ethnic elites:

They have been treated as gods for the past thirty years [...] They are supposed to be held accountable when they fail and they have failed us miserably. We are killing off their godlike aspect and bringing them down to the ground and when you have them on the ground, you will beat them up. (Interview No. 6, 2016)

\section{Pluralist Movements}

Pluralists are typically cross-cleavage groups who feel that their identities have traditionally been rendered mute or even anomalous in a divided society characterized by ethnonational/ethnoreligious conflict and either/ or approaches to social identity. Their job is to make wider society more appreciative of 'difference', especially in regards to issues concerning gender and ethnicity. If divided societies are characterized by intolerance, the purpose of pluralists is to be heterogeneous so that society, in time, will become more open to the presence of multiple identities. Examples of pluralist social movements in Northern Ireland include LGBT, feminist, and anti-racist mobilizations.

The LGBT rights movement in Northern Ireland emerged in response to Victorian legislation that criminalized homosexuality. Northern Ireland's first LGBT organization - the Gay Liberation Society (GLS) - began in 1971 to demand homosexual law reform. In 1974, members of GLS formed the Campaign for Homosexual Law Reform (CHLR), which was then followed by the Northern Ireland Gay Rights Association (NIGRA), a broad-based social movement designed to promote equality for the region's LGBT population (Nagle and Clancy 2010). The rise of the Northern Irish LGBT movement coincided with the intensification of violent conflict over national selfdetermination in the early 1970s. Political resistance to homosexual law reform came from the Rev. Ian Paisley, a unionist MP, who collected nearly 70,000 signatures as he led a petition to 'Save Ulster from Sodomy'. The campaign for law reform, led by LGBT activists, finally succeeded in 1981 
when the European Court of Human Rights declared that criminalization represented a violation of Article 8 of the European Convention on Human Rights.

Despite law reform, sexual minorities represented a marginalized community with little recognition within wider policy debates in Northern Ireland. Decriminalization did not represent a mandate for equality but a mere act of toleration. Whereas equality belies approval and acceptance, tolerance is a tacit form of disapproval and tolerance has limits. In response, LGBT activism started to mobilize in public spaces, especially an annual 'Belfast Pride' event, which began in 1991 with a short parade containing $5^{0}$ participants singing 'gay rights anthems' (Nagle and Clancy 2010:122). In the 1990s, Belfast Pride become a broader-based movement characterized by interleaved alliances seeking to pluralize a society defined by ethnonational division (Nagle 2013). Pride increasingly focused on a number of interrelated issues: achieving equality in all spheres of social life; increased visibility in public policy; and promoting diversity to foster mutual tolerance between all groups in society. Pride positioned the LGBT movement as a model of peaceful coexistence between groups.

The development of the Northern Irish peace process in the early $1990 \mathrm{~s}$ created the broader context for the LGBT movement to articulate an agenda for minority rights. At this point, increasing - albeit incomplete - consensus was that the conflict in Northern Ireland was essentially one anchored in identity: two ethnonational groups with clashing national self-determination aspirations. The peace process, consequently, centred on the discourse of 'parity of esteem' for ethnic identities. Within this framework, the LGBT movement situated itself as a peace process actor. Evidence of this can be seen in the official theme of the 1995 Pride celebration: 'Time for Peace, Time for Pride'. At the same time, NIGRA (1995: 1) declared its mission statement as 'Let Us Unite in Diversity': 'It is our object to found an organization not merely to protect the interests of minorities in Northern Ireland but to argue the fact that in diversity is genuine strength'. In subsequent years, organizers of Pride, both in the lead up and after the signing of the peace agreement, framed the event as a celebration of all forms of diversity to counter ethnonational polarization. Such emphasis on alliances and relationships is apparent in the theme given annually to Belfast Pride: 'Unity Through Diversity' (1998); 'One Community, Many Faces' (2001); 'Let's Respect Diversity' (2003).

The experience of Lebanon's sexual minority population is formed by Article 534, which criminalizes non-heterosexuality by carrying a maximum one-year prison sentence. Article 534's impact ranged from 
'discrimination in employment and arbitrary dismissal, to limited access to housing, health, and social services, to political and financial extortion' (Makarem 2011a: 100). A 2015 report noted that sexual minorities 'are still periodically arrested, detained, and tortured by Lebanese security forces, while incidents of societal and family-based discrimination have not abated' (Nasr and Zeidan 2015: 7).

Since Article 534 discouraged individuals from publically identifying as gay, it has been argued that that sexual minorities rarely 'express any particular group solidarity [...] based on a perceived common sexuality or one informed by a mutually embraced political cause' (Merabet 2014: 112-113). An LGBT activist explained to me: 'It is very difficult for me to conceive of a LGBT community in Lebanon much less a LGBT movement' (Interview No. 4, 2015). In other words, while there are many individual gay men and women in Lebanon, they have yet to identify themselves as part of a collectivity with unified political goals. The task of Helem, therefore, was to generate 'cognitive liberation' (McAdam 1982): the process through which activists encourage individuals to formalize shared understandings of their situation as one of oppression and marginalization so that they achieve groupness.

Despite unpropitious conditions for activism, LGBT social movements emerged. In Lebanon, most notably Helem, identified as the first gay rights movement in the Middle East and North Africa. Helem developed in 2002 out of a network of lesbians and gay men that socialized together and in 2004 became a public movement by forming an NGO to advocate on behalf of Lebanon's sexual minorities. Helem's strategic options were initially constrained by the law on criminalization, which deprived the organization from gaining official recognition as an NGO. In 2005, leading members were subsequently detained and interrogated by the security forces.

The emerging LGBT social movement in Lebanon interlinks its campaign against homophobia with the wider fight to oppose the political sectarianism of power-sharing. In interviews with Lebanese LGBT members, Naber and Zaatari (2014:100) note how these informants view 'Lebanon's sectarian structure $[. .$.$] as a key site of struggle not only because it is divisive [...] but$ also because it is patriarchal and requires compulsory heterosexuality'. An LGBT activist explained to me that the power-sharing 'system has always been opposed to us [sexual minorities]'. In turn, LGBT activists argue that their task is 'fighting to end confessionalism of the political system' (Makarem 2011a). A lesbian social movement called Meem (M. 2010: 15) is 'resisting sectarianism' since 'the biggest challenge to any form of social 
justice in Lebanon is the sectarian makeup of its society'. Thus, rather than mobilize for rights within the system, Lebanese consociationalism disavows the opportunities for sexual minorities to claim incremental reform. Meem argues:

$[\mathrm{H}]$ ow does one advocate for gay rights in Lebanon? Suppose the government did want to expand gay rights, how would they even do that? Any effort to reform laws and practices towards expansion of gay rights would have to negotiate independently with each religious community because [...] any major political development in Lebanon requires the support of all the various sects. (M. 2010:17)

Radical opposition to power-sharing embodies the protest politics of a body of LGBT activists. Some activists view 'Lebanon's sectarian structure [...] as a key site of struggle not only because it is divisive [...] but also because it is patriarchal and requires compulsory heterosexuality' (Naber and Zaatari 2014: 100). This opposition to power-sharing is evident in the statements of movement activists. For one former Helem leader, a fundamental objective of the LGBT movement is 'fighting to end confessionalism of the political system' (Makarem 2011b). A lesbian movement identified one of its major goals as 'resisting sectarianism', since 'the biggest challenge to any form of social justice in Lebanon is the sectarian makeup of its society' (M. 2010: 15). LGBT activists also align themselves with non-sectarian movements that call for political 'deconfessionalism', the abolition of power-sharing. Thus, Helem's development as an 'anti-imperialist movement led to the adoption of an anti-sectarian, anti-racist, and anti-xenophobic position' (Makarem 2011a: 105).

In identifying power-sharing as censoring non-heterosexuality, radical Lebanese activists oppose it. LGBT resistance, therefore, is articulated through rejecting a sectarian identity (Naber and Zaatari 2014: 103). Such politics, as Seidman notes (2012:22), is a 'resistance to identity-based models of self and politics [...] in a nation in which kin and sect impose enveloping and inflexible identities on all individuals'. One lesbian movement's (M. 2010: 9) 'very existence as a diverse [...] community - one of the rare few in Lebanon - is in itself a challenge to the sectarianism endemic in Lebanese society and politics'. The movement's non-identitarian resistance to the political sectarianism of power-sharing is further achieved by the relationships of members. To freeze the balance of power between the main groups, Lebanon's power-sharing system forbids marriage between members of different religious sects unless one of the partners converts to the other's 
religion. The existence of same-sex relationships that cross sectarian boundaries profoundly disturbs the ethnic mosaic in which individuals are assigned to monolithic and discrete communities. Naber and Zaatari (2014: 101) illuminate, in relation to Lebanon, that 'nonconformist sexuality challenges sectarianism, and there are more same-sex couples that come together across sectarian divides than heterosexual couples'. Yet, while LGBT activists view the movement as a challenge to political sectarianism, they also recognize that, in some ways, it can reproduce sectarian divisions. A Helem activist noted:

The way that confessional politics works here is amazing, because sometimes it seeps into the LGBT community itself, much less so than the rest of the country [...] You see a lot more bi-sectarian relationships among the community. However, you also notice that there are a lot of LGBT people with a heightened sense of confessional and religious belonging. They go to two churches, the gay bar and the actual church. (Interview No. 3, 2012)

\section{Conclusion}

The literature on social movements in ethnic conflict largely focuses on the mobilization of insurgents seeking to challenge state power (Olzak 2006; Gurr 2000; Della Porta 2013). These are groups historically excluded from the polity and which demand forms of national self-determination. Such social movements figure predominantly in the literature associated with the 'politics of collective violence' (Tilly 2003) and/or 'clandestine political violence' (Della Porta 2013). This focus is also evident in social movement research in Northern Ireland and Lebanon, though Northern Ireland merits a caveat in so far as there has been a rich corpus of literature on the inter-communal civil rights movement of the 1960s. Yet, in order to understand how conflict and peace is achieved in such societies, it is necessary to develop a broader analysis to include movements that do not readily fit into the dominant narrative. This mode of analysis is particularly important in relation to the aftermath of peace agreements, such as the Good Friday Agreement (1998) and the Taif Agreement (1989), since the objective of both agreements is to recognize and even strengthen the power of the main ethnic groups. Such models of conflict regulation are predicated on the assumption of the relative homogeneity of the respective groups. While ethnicity is undoubtedly a salient and widespread form of belonging 
and organization in divided societies, the ability of social movements to challenge, overcome, and even provide radical alternatives is extremely important.

Social movements can foster a public sphere of debate in which issues salient to all groups can be deliberated so that shared polices can be forged, and which make ethnonational politicians accommodate identities unconfined to their own narrow constituencies. This public sphere of debate is also essential to conflict resolution by allowing many issues of communal contestation to be aired so they can be potentially resolved through rational debate. Many movements also bring about many important policies that contribute to social change. The LGBT movement in Northern Ireland, for example, has successfully brought about many legislative changes conducive to engendering equality for gay and lesbian people in the region. As such, polices aimed at enhancing equality and the tolerance of diversity can make a significant alteration to the social structure.

At the same time, this chapter illuminates the complex ways in which non-sectarian movements operate in their respective societies relative to different types of power-sharing. In Northern Ireland's relatively liberal power-sharing form few movements purposely mobilize to directly reform or end consociationalism; instead movements - such as those associated with the May Day event - aim to provide alternatives to sectarianism. They are transformative movements in the sense that they desire to transform antagonistic concepts of ethnicity into ones more redolent of shared class encapsulations. In Lebanon, the corporate power-sharing system institutionalizes ethnicity to such an extent that non-sectarian movements - such as secularists - organize to directly transform this system by calling for the end of political sectarianism. A slightly different type of movement explored in the chapter concerns pluralists, groups that attempt to encourage cross-cutting and hybrid identities and interests.

\section{Interviews}

No. 1, with a May Day organizer, 2007

No. 2, with another May Day organizer, 2007

No. 3, with a Helem activist, September 2012

No. 4, with an LGBT activist, June 2015

No. 5, with a leading You Stink activist, January 2016

No. 6, with a You Stink leader, January 2016 


\section{Works Cited}

Al Jazeera. 2015. 'Lebanese Protest against Waste-Disposal Crisis'. Al Jazeera, 26 July. http://www.aljazeera.com/news/2015/o7/lebanon-beirut-trash-rubbishcrisis-150725060723178.html.

Amenta, Edwin, Neal Caren, Elizabeth Chiarello, and Yang Su. 2010. 'The Political Consequences of Social Movements'. Annual Review of Sociology 36: 287-307.

Belfast Telegraph. 2003. 'May Day parade set to draw the crowds'. Belfast Telegraph, 5 May.

Bourke, K. 2005. 'Gay Community to Stage Annual Parade'. Irish News, 6 August.

Della Porta, Donatella. 2013. Clandestine Political Violence. Cambridge: Cambridge University Press.

Diani, Mario. 2000. 'Simmel to Rokkan and Beyond: Towards a Network Theory of (New) Social Movements'. European Journal of Social Theory 3·4: 387-406.

Edwards, Aaron. 2007. 'Democratic Socialism and Sectarianism'. Politics 27.1: 24-31.

Finlay, Andrew. 2011. Governing Ethnic Conflict: Consociation, Identity and the Price of Peace. Abingdon: Routledge.

Gamson, William A. 1990. The Strategy of Social Protest. Belmont, CA: Wadsworth.

Giugni, Marco. 1998. 'Was It Worth the Effort? The Outcomes and Consequences of Social Movements'. Annual Review of Sociology 24: 371-393.

Giugni, Marco. 2004. Social Protest and Policy Change:Ecology, Antinuclear, and Peace Movements in Comparative Perspective. Lanham, MD: Rowman \& Littlefield.

Gurr, Tedd. 2000. Peoples versus States: Minorities at Risk in the New Century. Washington, DC: United States Institute of Peace.

Haddad, Simon. 2009. 'Lebanon: From Consociationalism to Conciliation'. Nationalism and Ethnic Politics 15-3-4: 398-416.

Hayes, Bernadette C., and John Nagle. 2016. 'Ethnonationalism and Attitudes towards Gay and Lesbian Rights in Northern Ireland'. Nations and Nationalism 22.1: $20-41$.

Helem. 2015. 'Article 534'. Helem, http://www.helem.net/?q=node/22.

Hermann, Tamar. 2009. The IsraeliPeace Movement:A Shattered Dream. Cambridge: Cambridge University Press.

Horowitz, Donald. 2000. Ethnic Groups in Conflict. Berkeley: University of California Press.

Kerr, Michael. 2005. Imposing Power-sharing: Conflict and Coexistence in Northern Ireland and Lebanon. Dublin: Irish Academic Press.

M., Nadine. 2010. 'Arab Queer Women and Transgenders Confronting Diverse Religious Fundamentalisms: The Case of Meem in Lebanon'. Association for Women's Rights in Development (AWID) . https://www.awid.org/sites/default/ files/atoms/files/feminists_on_the_frontline_-_arab_queer_women_trans.pdf. 
Makarem, Ghassan. 2011a. 'The LGBT Struggle in Lebanon', SocialistWorker.org, 2 February. http://socialistworker.org/2011/o2/o2/lgbt-struggle-in-lebanon.

Makarem, Ghassan. 2011b. 'The Story of Helem'. Journal of Middle East Women's Studies 7.3: 98-112.

McAdam, Doug. 1982. Political Process and the Development of Black Insurgency, 1930-1970. Chicago: University of Chicago Press.

McGarry, John. 2001. 'Northern Ireland, Civic Nationalism, and the Good Friday Agreement'. In Northern Ireland and the Divided World, ed. R. Wilford. Oxford: Oxford University Press, 109-136.

McGarry, John, and Brendan O'Leary. 1995. Explaining Northern Ireland: Broken Images. London: Wiley-Blackwell.

McGarry, John, and Brendan O'Leary. 2007. 'Iraq's Constitution of 2005: Liberal Consociation as Political Prescription'. International Journal of International Law 5.4: 670-698.

McGarry, John, and Brendan O'Leary. 2009. 'Power Shared after the Deaths of Thousands'. In Consociational Theory: McGarry and O'Leary and the Northern Ireland Conflict, ed. R. Taylor. London: Routledge, 15-84.

Meem (2009) Bareed Mistajjil. Meem: Beirut.

Melucci, Alberto. 1996. Challenging Codes: Collective Action in the Information Age. Cambridge: Cambridge University Press.

Merabet, Sofian. 2014. Queer Beirut. Austin: University of Texas Press.

Naber, Nadine, and Zeina Zaatari. 2014. 'Reframing the War on Terror: Feminist and Lesbian, Gay, Bisexual, Transgender, and Queer (LGBTQ) Activism in the Context of the 2006 Israeli Invasion of Lebanon'. Cultural Dynamics, 26.1: 91-111.

Nagle, John. 2013. “Unity in Diversity”: Non-sectarian Social Movement Challenges to the Politics of Ethnic Antagonism in Violently Divided Cities'. International Journal for Urban and Regional Research 37.1: 78-92

Nagle, John, and M.A.C. Clancy. 2010. Shared Society of Benign Apartheid: Peacebuilding in Divided Societies. Basingstoke: Palgrave Macmillan.

Nagle, John, and M.A.C. Clancy. 2012. 'Constructing a Shared Public Identity in Ethnonationally Divided Societies: Comparing Consociational and Transformationist Perspectives'. Nations and Nationalism 18.1: 78-97.

Nasr, Nour, and Tarek Zeidan. 2015. "As Long as They Stay Away”: Exploring Lebanese Attitudes towards Sexualities and Gender Identities'. Gender \& Sexuality Resource Center. Beirut: Arab Foundation for Freedoms and Equality. http:// afemena.org/wp-content/uploads/2015/12/Report-high-resolution.pdf.

NIGRA. 1995. Let's Unite in Diversity. Belfast: Northern Ireland Gay Rights Association.

Olzak, Susan. 2006. The Global Dynamics of Racial and Ethnic Mobilization. Stanford, CA: Stanford University Press. 
Seidman, Steven. 2012. 'The Politics of Cosmopolitan Beirut: From the Stranger to the Other'. Theory Culture Society 29.2: 3-36.

Socialist Environmental Alliance. 2005. 'Election flyer', Socialist Environmental Alliance.

Tilly, Charles. 2003. The Politics of Contentious Violence. Cambridge: Cambridge University Press. 



\title{
11 The Peace People
}

\author{
Principled and Revolutionary Non-violence in Northern \\ Ireland $^{1}$
}

Lee A. Smithey

The Peace People movement emerged in 1976 in response to a wave of intense violence that had grown in Northern Ireland since 1969. The movement quickly drew large crowds at mass rallies to protest violence, attracting international attention. Many of the people of Northern Ireland seemed ready to challenge the status quo of violence and sectarianism that had come to dominate everyday life. The Peace People movement, or the 'Community of the Peace People', adopted non-violent tactics and a non-violent ideology, challenged all forms of violence, worked to develop a democratic social movement organization, supported community relations and community development work, and called for a new unifying Northern Irish identity.

In the early stages of the movement, mass rallies were well-attended by both Catholics and Protestants. Enthusiasm ran high, and the movement enjoyed substantial support both at home and abroad. Indeed, Betty Williams and Mairead Corrigan, two of the movement's leaders, received the 1976 Nobel Peace Prize. During the second phase of the movement, the leaders proposed an expansive plan for grass-roots transformation of the region, both politically and culturally. However, two years later, the organization suffered from financial challenges, and internal dissension came to a head.

The energy of the movement's launch and the scope of the Peace People programme were remarkable. During the first phase of rallies, it was as if the normal ethnonational fault lines became less salient in a liminal moment as tens of thousands of people joined together in public demonstrations. Ciaran McKeown, Mairead Corrigan, and Betty Williams sought to provide direction and leadership in this unusual moment of collective emotional outpouring. Through the organization, they also worked to build

1 Sections of this chapter also appear in Smithey (2009). The author thanks Anne Kane, Lester Kurtz, Rob Fairmichael, and Matt Meyer for feedback on earlier drafts of this chapter. Any mistakes belong to the author. The Swarthmore College Peace Collection provided access to the newsletters of the Peace People organization. 
further participation, a democratically elected central social movement organization, a network of community-based chapters, and a constructive programme to address contemporary social issues. All the while, they hitched their work to the transnational peace movement, establishing relationships with prominent peace activists and organizations in the United States, Latin America, Europe, and the Middle East. The Peace People movement constituted a significant challenge to political violence in a region wracked with bombings, assassinations, and covert and overt military operations. The leadership envisioned an end to violence; transformation of longstanding sectarian divisions; social, political, and economic reform; a new Northern Irish identity; and a new local political system, all achieved through non-violent organizing within a framework of love and respect for humanity. Participants were initially optimistic about the movement's potential, though some observers remained guardedly pessimistic, expecting the movement to quickly disappear as other grass-roots interventions had done. Politicians initially dismissed the movement's potential, but later became frustrated with their inability to co-opt it. The Peace People were not following the usual sectarian and political scripts employed by other political actors, and this afforded a novelty that appealed to many otherwise disillusioned citizens.

As the editors explained in their introduction, this long-awaited volume brings together social movement research and scholarship on divided societies, encouraging us to think more deeply about how social movements play important roles in what are often called 'intractable' identity conflicts and how the dynamics of such conflicts shape collective action. They furthermore highlight the importance of 'actor-based approaches' and the 'contextualizing of contentious politics'. In this chapter, we examine a social movement with leaders who sought to overcome ethnonational identity barriers, rejuvenate local democracy, and further a global peace and justice movement. To understand its emergence and decline, it is important to take into account historical, political, and socio-economic conditions as well as movement strategy and cognitive and cultural forces. The Peace People constituted a direct non-violent response to violent conflict that had deepened ethnonational division. However, the strategic and ideological choices that movement leaders made to embrace non-violent methods and praxes proved crucial in shaping the trajectory of the movement.

The movement has been documented by McKeown (1984), Fairmichael (1987), and Deutsch (1977), though it has rarely been taken up in academic literature and usually only evokes passing reference by historians. The case could lend itself to a range of analyses of leadership, organizational 
structures, transnational movement, gender studies, conflict transformation, and more. Here, I focus on the cognitive and cultural dimensions of the relationship between the expansive programme laid out by Williams, Corrigan, and McKeown (the latter two in particular) and movement participants.

Cultural considerations have become well-grounded in the study of social movements, and as I have argued elsewhere (Smithey 2009), sociologists are now beginning to turn their attention towards the cultural implications of the methods that social movement organizations employ, including the use of non-violent action. This is an exciting new vista of research that views conflict as a culturally rich form of interaction within and between contending parties. It is important to remember, however, that the effects of the framing work and strategic action decisions that movement leaders make are contingent on the socio-historical contexts in which movements emerge, the cultural terrain that both enables and constrains movements. In the case of the Peace People, their far-reaching non-violent agenda allowed them to distance themselves from the usual spiral of ethnonational conflict that wracked the region, but it also proved difficult to sustain.

The Peace People represented what Nagle (in this volume) calls a 'transformationist' social movement. Much as the trade union movement in post-accord Northern Ireland has worked to challenge sectarianism through appeals to class identity and a common humanity, the nonviolent programme and ideology advocated by the Peace People movement leadership aimed to transform the familiar sectarian terrain of Northern Ireland. They called for a new post-sectarian identity and new political systems decoupled from ethnonational divisions. Whether and how such a revolutionary programme of non-violent transformation could be made to resonate broadly in the midst of an 'intractable' ethnonational conflict constitutes the particular focus of this chapter.

Ethnonational identities often become monolithic and polarized in the heat and trauma of violent conflicts, and trying to soften or diversify collective identities is a common goal of conflict transformation efforts. Fortunately, collective identities are malleable, but only within limits (Todd 2005; Jenkins 2008; Wimmer 2008). Through framing processes, movement leaders can work to shift the cultural terrain of collective identities, prioritizing some over others. However, such transformative work is never unconstrained. It takes place within a field of historical experience, countervailing identities, and predispositions. Leaders with a deep understanding of their own in-groups often have the cultural capital to introduce new interpretations of where group boundaries lie. Such change 
is incremental, and leaders can stretch their constituents too far when they call them to radical new interpretations of collective identities that outpace constituents' abilities to reconcile the new models with those they have already internalized (Smithey 2011). Certainly, many factors were responsible for the Peace People's downturn, including internal contention, funding problems, and leadership challenges (Fairmichael 1987), but this chapter will focus on the crucial interaction between the principled and revolutionary non-violence that the movement's leaders envisioned and cultural and ideological preferences in Northern Ireland. ${ }^{2}$

After relaying the series of events that led to the rapid rise of the Peace People and the two main phases of the movement's development, I present the framing of movement values and goals as an important process through which to observe the challenges movements face when trying to overcome centrifugal forces of division in the midst of a violent ethnonational conflict. Moreover, I argue that the leaders of the Peace People called participants not just to non-violent action but to extensive ideological commitments to principled and revolutionary non-violence. They aimed to escape the relentless pull of everyday violence and trauma, a broken political system, and polarized collective identities, but their goals proved too great a departure from the lived experience and habitus of many in Northern Ireland.

\section{The Peace People}

On Wednesday, 11 August 1976, one day after a car chase resulted in the fatal shooting of an Irish republican Army (IRA) volunteer by the British military and the deaths of three children, 50 women in the republican neighbourhoods of Andersontown and Stewartstown in Belfast protested republican violence by marching with baby carriages. Later that evening, Mairead Corrigan, ${ }^{3}$ an aunt of the children, appeared on television, pleading for an end to violence. Betty Williams took action door to door in her neighbourhood with a petition protesting paramilitary violence. By the following evening (Thursday), Williams had collected 6ooo signatures (Deutsch 1977: 6). She also scheduled a rally to take place the next day

2 The analysis I offer draws on secondary literature about the Peace People movement, published first-hand accounts by activists and observers, and articles from The Times of London, and the movement newsletter, Peace by Peace (1976-1978).

3 Mairead Corrigan later married her sister's husband after her sister's death, and she is therefore referred to in more recent literature as Mairead Corrigan Maguire. 
in Andersontown. Ten to fifteen thousand women, both Protestant and Catholic, attended (McKeown 1984: 142-143).

Corrigan and Williams were generally recognized as the leaders during the early months of the movement, and Ciaran McKeown, a journalist and non-violent activist, soon joined them in leading the movement for the next three and a half years. The first movement participants were almost exclusively women, and the press often referred to the movement as the 'womens' movement' (Walker 1976b). The leaders promptly sought to include all citizens, and they adopted the name, 'Peace People'.

\section{Phase One - Rallies}

The initial phase of movement activity extended from the first rally in West Belfast on 14 August 1976 through a rally in Drogheda in the Republic of Ireland on 5 December 1976. At least 26 marches or rallies took place in Northern Ireland, Britain, and the Republic of Ireland, attracting intense international media attention and international financial and political support. Meanwhile, 'Peace Committees' or local groups (110 by one count) sprang up in communities as participants in the rallies organized themselves, and a group development programme was arranged to support local organizations (Deutsch 1977:159; Fairmichael 1987:13). The leaders secured a meagre central office in Belfast to facilitate communication between the various peace committees that formed and established an Assembly and Executive committee.

The first rally boasted between 10,000 and 15,000 participants (Geddes 1976a; McKeown 1984). The rally on 21 August in Protestant East Belfast involved more than 20,000 people, and the rallies on Belfast's Shankill Road and in Derry/Londonderry each attracted around 25,000 participants (Geddes 1976b; Walker 1976b). These were the largest, but other marches and rallies across Britain, Northern Ireland, and the Republic of Ireland involved thousands more participants. Fairmichael (1987:6) estimates roughly that 100,000 people in Northern Ireland (approximately 6.5 per cent of the population) attended at least one rally. The death of the Maguire children had revealed collective concerns within the war-weary public about the continuing violence, and the rallies became catalytic rituals through which many in Northern Ireland sought to reframe the boundaries of acceptable political action and surmount deeply entrenched ethnic and political divisions.

The movement also attracted international media attention. Camera crews arrived from the United States and European countries to document 
the movement's activities. McKeown, Williams, and Corrigan travelled to the United States on at least two occasions for television interviews and meetings with members of Congress, including Senator Edward Kennedy. The Norwegian People's Peace Prize, organized by Norwegian media, raised more than $£ 200,000$ for the movement by December 1976, and Corrigan and Williams received the 1976 Nobel Peace Prize in December 1977.

\section{Phase Two - Community Politics}

The second phase of the movement began in early January 1977 as the leadership organized for the long-term maintenance of the movement and set out goals that would fulfil their vision of grass-roots transformation. Community peace groups had formed during the rally phase, and the leadership planned to coordinate them in a bid to create new 'community politics' and a shared 'Northern Irish' identity that would transcend polarized political identities (McKeown 1976: 24-25; 1984: 1, 4). In McKeown's (1984:189) words:

Our more immediate concern was with the low-level application of these ideas in the wake of 'hot war' [...] Our purpose was to encourage such neighbours to take an active interest in the quality of life of their own streets and districts, to feel that they had friends in other communities busy in the same genuine patriotism, and that together they would defeat the deepest law of repression, 'whatever you say, say nothing'.

To support this programme of grass-roots transformation, a non-profit company and trust were set up to disburse funds to community improvement programmes and small businesses. An 'escape route' was established to relocate those who wanted to defect from paramilitary organizations. At the same time, effort was directed towards establishing a sustainable organization to coordinate efforts. The strategy was designed to encourage a measure of self-esteem and mutual identification among the people of Northern Ireland that would eventually erode the sectarian bases for continuing violence and establish a social, political, and economic platform for self-governance.

However, over time, the movement began to experience difficulties among the leadership and community groups, many of which faltered after the rally phase. A train was chartered to take members to a rally in Dublin on 18 February 1978, but by then, many had lost interest, and the event was not considered as successful as earlier rallies (Walker 1978). Concern arose over the use of funds, including the Nobel Peace Prize award 
to Corrigan and Williams. Controversy also developed over McKeown's prominence in decision-making and the organization's fiscal strategy as limited funds ran short and loans were written off (Deutsch 1977; McKeown 1984). To demonstrate their faith in the democratic structures that had been established and to encourage greater grass-roots ownership of the programme, McKeown, Corrigan, and Williams all resigned from the Executive committee in October 1978. Peter MacLachlan, formerly a prominent unionist politician, took over the chairmanship of the Executive.

\section{Framing Non-violent Revolution in a Divided Society}

Meaning making has become a central task of the study of social movements. Social movements introduce new narratives and discourses that are no less important than the demands they make of their opponents. They engage in 'framing' battles as they seek to legitimate new policies and often lifestyles and delegitimize those of their opponents. To mobilize participants, movement leaders develop frames and narratives about themselves and their opponents that resonate with potential movement members. In their early groundbreaking work on framing, Hunt, Benford, and Snow (1994) describe a 'frame alignment process' 'by which social movement organizations (SMO) seek to bring the beliefs and attitudes of potential recruits into sync with the ideological frame of the movement' (Hunt, Benford, and Snow 1994; McAdam, McCarthy, and Zald 1988: 725). A major element of the process is the creation (or realignment) of in-group and out-group identities (Hunt, Benford, and Snow 1994: 193-194). They stress that this process of identity formation is ongoing and that SMOs must be persistent if they hope to succeed.

However, framing contests take place in pre-existing fields of collective identities, preferences, and interests. The alignment of movement goals with pre-existing narratives, discourses, and identities is a particularly important challenge (Woehrle, Coy, and Maney 2008). Eyerman and Jamison (1991: 5657) stress the compatibility of the movement's message with contemporary norms and cultural expectations, or the 'willingness and capacity of the entire social formation to absorb, incorporate, or reject the "message" of the movement'.

Cognitive dissonance can set in when a movement's ideological basis or praxis ${ }^{4}$ conflicts with participants' pre-existing cognitions. As a movement's

4 Eyerman and Jamison (1991: 46) define praxis as a "'packages of ideas" or clusters of issues, or, perhaps most ambitiously, as organizational ideologies or profiles'. 
ideology and frames must compete in a cultural and political space against other competing ideologies and norms, we should explore successes and failures in these battles of ideas. The relationship between movement praxis and the level of integration among movement participants also becomes particularly relevant when studying the Peace People's efforts to reach their stated goals of a radical new democracy in a highly segregated society. I focus in this chapter on a particular set of non-violent praxes, principled and revolutionary non-violence, that served as central ideologies in the Peace People movement.

\section{Principled Non-violence}

'Principled non-violence' refers to an ideology or system of ideas and beliefs that accompany and legitimate the use of non-violent civil resistance while calling adherents to repudiate violence and encourage pre-figurative collective action. A brief look at several central elements of Gandhi's non-violent philosophy help illuminate the basics of principled non-violence (Gandhi 1962, 1967, 1986; Kurtz 2008). For principled activists, non-violence:

- is spiritual or metaphysical;

- is ethically or morally superior to the use of violence;

- should be practiced as a lifestyle;

- can produce new societal paradigms;

- separates the doer (opponent) from their deeds (oppression);

- assumes a oneness among humans.

Principled non-violence is both a strategy and a belief system. Adherents to principled non-violence reject the use of violence on moral and ethical grounds and insist that violence is ultimately more destructive than productive. Thus, means and ends become inseparable. Those who advocate principled non-violence emphasis its moral and strategic superiority for achieving the interests of their group and, ultimately, even their opponents.

\section{Revolutionary Non-violence}

The Peace People leadership also called for revolutionary non-violence, a praxis that shares many of the fundamentals of strategic non-violent action and principled non-violence. ${ }^{5}$ According to the peace activist, scholar, and

5 The now familiar distinction between strategic and principled nonviolence should not imply that non-violent revolutionaries are without strategy or principles. 
educator Matt Meyer, 'Revolutionary nonviolence emphasizes unity among radicals and proposes a militant non-violent praxis based on revolutionary transformation and mass civil resistance. ${ }^{6}$ Meyer (2014) asserts that revolutionary non-violence requires careful introspection of structural violence, colonial histories, and power structures. And while it might be argued that the Peace People side-stepped issues of colonial history in Ireland, the leadership felt that an end to violence would be necessary but not sufficient. A lasting peace would require root-and-branch transformation of politics, economics, and social relations through mass organizing and grass-roots action.

The organization's newsletter reveals consistent efforts to express solidarity with contemporary activists and movements often associated with revolutionary non-violence, such as the Plowshares movement, Movement for a New Society, advocates of Catholic liberation theology, and non-violent revolutionaries, such as the Berrigan Brothers and Steve Biko in South Africa (Meyer 2014). Many of the Peace People were inclined to participate in local social work, community development activities, or mass rallies, but a revolutionary programme that sought to address global economic disparities or authoritarianism in other countries proved elusive and even offensive to some.

\section{The Peace People and Principled Non-violence}

From the beginning, the main leaders embraced a radical non-violent ideology. Betty Williams' initial efforts gathering signatures for a petition protesting the death of the Maguire children expressed a simple desire for an end to violence and the dissolution of the IRA. She declared, 'After such a tragedy, we must and will have peace!' (Deutsch 1977:6). Mairead Corrigan responded boldly to threats by the IRA: 'We realize that before this is finished people may have to die for peace in Northern Ireland. But this only makes us more determined than ever, as none of us can think of a better cause to have to die for' (Walker 1976a). Ciaran McKeown soon joined Williams and Corrigan and brought a new sophistication to the leadership's non-violent vision. After the rallies subsided, McKeown intended for the movement to generate pressure through 'community politics' and new power-sharing arrangements, but he also envisioned changes in hearts and minds.

6 https://web.archive.org/web/20150808153426/http://beautifultrouble.org/theory/ revolutionary-nonviolence/. 
Williams and Corrigan remained the central spokespeople, but McKeown (1976) penned the Peace People Declaration and a pamphlet entitled The Price of Peace, in which he framed the movement's potential and long-term goals. It is in McKeown's writings that one often finds calls to principled non-violence, such as those enumerated in the Gandhian template above.

\section{Use of Spiritual, Metaphysical, or Religious Tenets}

Northern Ireland is a highly religious region within Europe, and the three primary leaders often drew on Christian theology and practice, especially Corrigan and McKeown. They spoke in familiar religious terms, and they used theological principles to emphasize the importance of non-violence and the oneness of humanity. McKeown (1976:14) wrote, 'If you believe in God, you will already know your own value as a divinely created person with the possibility of a divine destiny [...] you will know that you must have an equal respect and love for his other creatures'. Mairead Corrigan, a devout Catholic, often drew on her faith and spoke of love and forgiveness as she did in her regular column in the movement newsletter, Peace by Peace.

\section{Non-violence Is Morally Superior}

McKeown highlighted the virtue of non-violence and emphasized the need for courage to carry out principled non-violence: 'Both logically and emotionally, it takes far more courage to be prepared to die, but never to kill, than it takes to be prepared to kill and take your chance on dying' (1976: 3). Courage emerges as a recurring virtue that Williams, Corrigan, and McKeown associated with non-violence. In their Noble Peace Prize lecture, Williams and Corrigan (1977) contrasted global militarism and military expenditures with courageous non-violence:

We know that this insane and immoral imbalance of priorities cannot be changed overnight: we also know that it will not be changed without the greatest struggle [...] And that struggle must be all the greater because it has to be an unarmed, a nonviolent struggle, and requires more courage and more persistence than the courage to squeeze triggers or press murderous buttons.

In this excerpt, Williams and Corrigan frame non-violent action as courageous (and difficult) and imply by contrast that violence is easy and cowardly. 


\section{Non-violence as a Lifestyle}

Applying non-violent philosophy in all areas of one's life coincided with the movement's goal of transforming society from the bottom up. Whether dealing with domestic conflicts in the home (McKeown 1976: 18) or working to build the movement, one's commitment to non-violence required continuous discipline. According to McKeown (1976:3), 'the genuine pacifist is engaged in a battle every day of his life'. In the 20 May 1977 issue of the movement's newspaper, nearly a full page was dedicated to an article about the Community of the Ark (L'Arche), a non-violent community in France, where,

To become the instrument of non-violence and unity, intelligence and affections must be constantly renewed and animated by Truth and Living Love [...] This is why the members of the non-violent community must seek together every day the spiritual strength in which they may find comfort, surmount their oppositions and live in a practical unity which reaches out to every person, even an adversary. (_.1977:5)

While the Community of the Peace People did not develop communal living, the basic principle of daily commitment was consonant with the bottom-up transformation of Northern Ireland that lay at the heart of the leadership's programme.

\section{New Societal Paradigms}

Advocates of principled non-violence focus not only on the means of nonviolent struggle but also on non-violent ends of more peaceful and just economic, political, and social relationships. McKeown criticized Northern Ireland's limited 'party-political' system and its inability to provide a solution to the Troubles. He felt any sustainable peace process would be produced from the grass roots. Only by transforming sectarian impulses at the individual and community level could a consensus be built. McKeown (1976) also felt the energy of the movement provided an opportunity to create an entirely new and unprecedented political system, an 'optimum' democracy (McKeown 1976: 27). Moreover, McKeown's transformationist vision called for a revolutionary new society distinguished by 'peace culture’:

Those with a deep interest in peace beyond a mere end to violence will have a special role in helping to create a 'peace culture' which will 
compete with and finally replace the received and meekly accepted cultural tradition with its violent tones, undertones and overtones. In short, we are attempting nothing less than the creation of a new civilization (1976: 28).

Campaigns were proposed to reform policies, such as police interrogation practices and Diplock courts, and to institute corrective policies, such as emergency status for prisoners charged under the Emergency Provisions Act. Together, they reflected the call for a new vision of a just future.

\section{Oneness of Humanity and Separating the Doer from the Deed}

Principled non-violence is often underpinned by a belief in a fundamental equivalence (and sometimes even metaphysical unity) of all humans, challenging processes of dehumanization that legitimate violence. McKeown touched on the oneness of humanity in his recognition of divinity in all humans, but more often, he emphasized Western concepts of individual liberties that all people share. Corrigan, writing in the Peace by Peace newspaper, declared that in the afterlife, 'I will be judged as a child of the universe and on my capacity to love all men of all nations' (Corrigan 1978:3).

A universalist position on the unity of all humans that considers humanity fundamentally good requires a way to distinguish humanity from destructive human behaviour and provide a pathway to atonement. McKeown and his successor as chairman of the Peace People Executive, Peter McLachlan, agreed that an authentic peace process, and ultimately reconciliation, would require involving ex-combatants from all sides and differentiating perpetrators from their violent actions in order to incorporate them into a new emerging society. As editor of Peace by Peace, McKeown published pieces by Gusty Spence, an imprisoned leader of the loyalist Ulster Volunteer Force paramilitary, and he foresaw a time when those, like Spence who had previously been involved in violence, should be released from prison (McKeown 1984: 188).

\section{Aligning Principled and Revolutionary Non-violence with Northern Ireland Culture}

Why did the movement decline? A complete answer lies beyond the scope of this chapter. I propose, as only one factor, that many who participated in the rally phase could not fully embrace the revolutionary scope of the 
programme formulated by the movement's leadership. McKeown's philosophy of non-violence constituted not only a set of strategies for achieving a conventional political end. He proposed a redefinition of the entire political structure and human relations in Northern Ireland.

Northern Ireland's unique historical context, including its divided political system and the traumatized collective psyche of the region, generated both opportunities and constraints for the movement. According to Fairmichael (1987:3), a genuine political vacuum was left in the wake of politicians' failures to establish a power-sharing government in 1973 . Moreover, the deaths of the Maguire children further dramatized the daily violence of the Troubles, evoking a public sense of outrage. Deutsch (1977), Fairmichael (1987), McKeown (1976: 11), and McKeown (1984) each noted a war-weariness or demoralization hanging over the region that reached a critical mass as the Peace People emerged (Deutsch 1977: 24). Unemployment had risen to record levels, and rates of violent deaths and injuries had risen to levels not seen since 1972 (Fairmichael 1987). As McKeown (1984: 139) describes, 'Violence was consuming itself, it seemed, and could beget no more violence [...] A volcano working up from the depths of the communal soul was looking for an outlet'. The bold and unconventional responses of Betty Williams and Mairead Corrigan provided an outlet for a collective frustration that had been building.

Even though Northern Ireland's troubled past provided an impetus for the Peace People, the context in which a movement emerges can also constrain it. Herein, one finds an important paradox in the emergence and maintenance of the Peace People. The non-violent nature of the movement made it appealing to the war-weary citizens of Northern Ireland. Yet, in the long run, the extensive commitment to principled and revolutionary non-violence proved unsustainable, because the Peace People's leaders were unable to align their non-violent praxis with the culture and experience of the people of Northern Ireland.

As Eyerman and Jamison (1991) point out, the ability of movement intellectuals to convey a movement's ideological foundation is important to the movement's capacity to establish and maintain itself. More importantly, a movement's ideology only has significant meaning when the meaning is collectively attributed or assigned (Kane 2011). Structural and cultural conditions hindered widespread adoption of an elaborate and radical programme of revolutionary non-violence and political transformation in Northern Ireland.

Ethnonational identities in Northern Ireland constitute important 'crosscutting solidarities' that can inhibit movement (McAdam, McCarthy, and 
Zald 1988), and the Peace People drew support from a divided constituency harbouring divided loyalties. Consequently, the Peace People's ideology tended to conflict with pervasive local configurations of identity fields. Among Peace People participants, ethnonational loyalties varied in intensity, but they persisted. McAdam, McCarthy, and Zald (1988: 704) argue that the greater the number and strength of such cross-cutting ties, the less likely a social movement will be able to emerge. As McAdam (1982: 49) argued when he introduced micro-mobilization processes to the study of social movements, 'It is not simply the extent and speed with which insurgency is spread but the very cognitions on which it depends that are conditioned by the strength of integrative ties within the movement's mass base'. It is equally true that once a social movement emerges, cross-cutting solidarities may also serve to precipitate its decline, especially when movement participants are already culturally predisposed to segregation (Bardon 1992: 727; Gamson 1995). The principled and revolutionary non-violent ideology of the Peace People became problematic as their leaders sought to redefine boundaries in Northern Ireland in radically egalitarian ways.

There are surely several reasons for the waning local support and the eventual decline of the Peace People during the movement's second phase. These include frayed relationships, financial problems, and misconceptions regarding the leadership's international roles (Fairmichael 1987; Walker 1978). ${ }^{7}$ However, events during the second phase and appraisals by observers and participants indicate that the goals of the movement, derived from principled and revolutionary non-violence, proved unacceptable to a significant portion of the movement's potential supporters. Movement participants were constantly confronted with the incongruity between their experience and the official non-violent vision for the movement. Richard Deutsch (1977: 175), who observed and documented the movement, offers this 'critical evaluation':

In many ways, the Northern Irish were not ready for the ideas of the Peace People. They were astonished by the plans, the scope of the program and of the thinking behind it. They must make a mental adjustment. They wanted peace, almost an immediate peace, a 'natural' peace without problems and without sacrifices. Then along came the Peace People and overwhelmed them with new thoughts and grandiose projects. Instead of bringing ready-made solutions, they asked for an extra effort, a collective

$7 \quad$ Further scholarly historiography of the movement could expand on Fairmichael's (1987) investigation and serve to elevate these factors in subsequent analyses. 
effort and, above all, a personal effort. And that, no doubt, is why the movement has met with so much resistance.

McKeown also found that the commitment of the movement's leaders to a radical philosophy of non-violence proved problematic:

By and large, in our early declarations of purpose, we were benignly dismissed as naive idealists, who might be forgiven such aberrations as nonviolence, in favour of the excellent promotional job we were otherwise doing. It would be much later, as it became clearer that nonviolence was the be-all and end-all of our commitment, that benign patronisation would give way more generally to irate opposition. (McKeown 1984: 177)

A couple of Ciaran McKeown's proposals for Peace People action demonstrate internal disconnects between what Fairmichael (1987:43) characterizes as the 'prophetic' (or revolutionary) project of non-violence backed by the leaders and the 'quieter project work' on which others wanted to focus.

First, contention over the treatment of prisoners held under the terms of the Emergency Provisions Act presented a significant stumbling block. Secretary of State Merlyn Rees withdrew 'special category status' for prisoners convicted of crimes after 1 March 1976. Republican prisoners protested this reversal, first by refusing to wear prison uniforms and then by refusing to use the sanitary facilities and smearing their own faeces on the walls of their cells. McKeown proposed that the issue be resolved by establishing an 'emergency status' for prisoners charged under the Emergency Act. Thus, those with extensive sentences established under the emergency situation would not be subject to the sentences indefinitely once the emergency ended. For McKeown (1984: 250), the prison issue was a crucial one on which the trajectory of the conflict could depend. It 'was the very touchstone of our seriousness as a peace movement seeking to work at the heart of the conflict'. The Peace People Assembly backed the proposal during its conference in October 1978, but for many Peace People, focusing on the politically charged prison issues amounted to 'becoming political' and risked upsetting the reconciliation work with which they were more comfortable. Others simply could not stomach extending any sort of relief to those they considered convicted terrorists (? 1978: 8).

Others found the international focus of McKeown, Williams, and Corrigan too ambitious or distracting. McKeown (1984:221-224), in particular, felt that Peace People groups should be actively involved in solidary relationships with other peace groups around the world as an appropriate expression of 
the unity of humanity. 'It seemed to me that we could not seriously tackle Northern Ireland's problems with the appropriate non-violent strategy and determination, if we did not have a constant, relentless appreciation that every human life is sacred: and that understanding dictated an immediate and active concern about "Third World" conditions' (1984: 223) (cf. Lakey 1973: 75-76). Hazel Senior of the Holywood Peace Group described the disconnect over international solidarity in an interview with Rob Fairmichael (1987:39):

Some of our people are very much if I may use the phrase, into nonviolence, and this means that perhaps they are just as involved in the non-violent aspect worldwide. For others I feel that they're interested in peace in Northern Ireland and that nonviolence might come into their vocabulary equally. I think in some ways people regard it as an academic thing.

These sorts of disputes represent a problem with framing and collective attribution, an inability of movement intellectuals to reconcile their radical non-violent philosophy with participants' understandings of reality. After all, framing is only one part of an interactive process of meaning making within social movements as participants experience, interpret, and internalize discourses over time from within their own socio-economic, cultural, and historical contexts (Kane 2011). As the Peace People emerged in a flash of weary frustration at the height of the Troubles and the three main leaders assumed such prominent roles, there was less opportunity for a more organic development of the movement's claims.

\section{Conclusion}

Collective identities play central roles in both ethnonational conflicts and social movements. Conflict, whether violent or non-violent, can deepen and polarize ethnonational boundaries, but some movements call for realignments of identities and social structures (see Nagle, in this volume). Nevertheless, each social movement emerges within its own political and historical context, and its praxis competes with other contradictory and established identities and ideological commitments. Careful framing can take advantage of the malleable nature of identities and introduce new models of identification that rearrange or transcend normal boundaries. However, new models introduced in moments of social movement can also prove too radical. To the extent that leaders' goals contradict or challenge 
prevailing identities and habitus, social movement organizations will find recruiting and retaining participants challenging.

The Peace People in Northern Ireland emerged in a society marked by deep social, political, cultural, and psychological divisions. Many citizens opened to new ideas of reconciliation and social change during the rally phase of the movement. McKeown, Corrigan, and Williams envisioned an unprecedented, totally inclusive, and non-violent society, a radical democracy that would arise from individuals deeply committed to principled non-violence and aligned with a global network of solidary movements, but Northern Ireland presented a difficult environment within which to establish and maintain support for a movement based on a combination of principled and revolutionary non-violence, especially once the effervescence of the early rallies faded. The scope of the leaders' goals exceeded the immediate desire for an end to violence and required a reconfiguration of world views extensive enough that their programme could not maintain broad support. For some, the immediacy of the Troubles trumped international solidarity, for others their views on justice precluded the call to reintegrate ex-combatants, and still others could not reconcile the poles of principled and revolutionary non-violence when called on to intervene and restructure the political system. These disconnects on matters of policy signal a deeper problem in meaning making at the intersection of framing and collective attribution.

\section{Works Cited}

_.1977. "The Community of the Ark: An Experience of Non-violent Society”. Peace by Peace 2.5 (20 May): 5 .

_. 1978. "An Open Letter to the Editor and Members of the Executive". Peace by Peace 3.18 (29 September): 8 .

Bardon, Jonathan. 1992. A History of Ulster. Belfast: Blackstaff Press.

Corrigan, Mairead. 1978. 'Irish, British, Northern Irish or 'A Child of the Universe'. Peace by Peace 3.20 (27 October)

Deutsch, Richard. 1977. Mairead Corrigan, Betty Williams. Woodbury, NY: Barron's Educational Series.

Eyerman, Ron, and Andrew Jamison. 1991. SocialMovements: A Cognitive Approach. University Park: Pennsylvania State University Press.

Fairmichael, Rob. 1987. 'The Peace People Experience'. Dawn Train 5.

Gamson, William A. 1995. 'Hiroshima, the Holocaust, and the Politics of Exclusion: 1994 Presidential Address'. American Sociological Review 60: 1-20. 
Gandhi, M.K. 1962. The Essential Gandhi, ed. Louis Fischer. New York: Vintage Books.

Gandhi, M.K. 1967. The Mind of Mahatma Gandhi, ed. R.K. Prabhu and U.R. Rao. Ahmedabad: Navajivan Publishing House.

Gandhi, M.K. 1986. The Moral and Political Writings of Mahatma Gandhi, vol. 2, Truth and Nonviolence, ed. Raghavan Iyer. Oxford: Clarendon Press.

Geddes, Diana. 1976a. 'Dispute Over Security in Northern Ireland Denied'. The Times (London), August 16, p. 2.

Geddes, Diana. 1976b. 'Mr. Rees Would Like Mrs. Drumm to Be “Locked up"'. The Times (London), August 3o. p. 3.

Hunt, Scott A., Robert D. Benford, and David A. Snow. 1994. 'Identity Fields: Framing Processes and the Social Construction of Movement Identities'. In New Social Movements, ed. Enrique Laraña, Hank Johnston, and Joseph R. Gusfield. Philadelphia: Temple University Press, 185-208.

Jenkins, Richard. 2008. Social Identity. New York: Routledge.

Kane, Anne. 2011. Constructing Irish National Identity: Discourse and Ritual during the Land War, 1879-1882. New York: Palgrave Macmillan.

Kurtz, Lester R. 2008. 'Gandhi and His Legacies'. In Encyclopedia of Violence, Peace \& Conflict, ed. L.R. Kurtz. $2^{\text {nd }}$ ed. London: Elsevier, 837-851.

Lakey, George. 1973. Strategy for a Living Revolution. New York: Grossman.

McAdam, Doug. 1982. Political Process and the Development of Black Insurgency, 1930-1970. Chicago: University of Chicago Press.

McAdam, Doug, John D. McCarthy, and Mayer N. Zald. 1988. 'Social Movements'. In The Handbook of Sociology, ed. Neil J. Smelser. Newbury Park, CA: Sage, 695-737.

McKeown, Ciaran. 1976. The Price of Peace. Belfast: Ciaran McKeown.

McKeown, Ciaran. 1984. The Passion of Peace. Belfast: Blackstaff Press.

Meyer, Matt. 2014. 'Rebuilding Revolutionary Nonviolence in an Anti-Imperialist Era'. Peace Review: A Journal of Social Justice 26:1, 69-77.

Smithey, Lee A. 2009. 'Social Movement Strategy, Tactics, and Collective Identity'. Sociology Compass 3: 658-671.

Smithey, Lee A. 2011. Unionists, Loyalists, and Conflict Transformation in Northern Ireland. Oxford: Oxford University Press.

Todd, Jennifer. 2005. 'Social Transformation, Collective Categories, and Identity Change'. Theory and Society 34: 429-463.

Walker, Christopher. 1976a. 'IRA Threatens Peace Supporters after Rise in Information to Security Forces'. The Times (London), 27 August, p. 1.

Walker, Christopher. 1976b. 'Coming Weeks Will Show Whether New Ulster Peace Movement Can Have Lasting Influence'. The Times (London), 6 September, p. 2. Walker, Christopher. 1978. 'Peace Movement Loses Local Support as Criticism Increases'. The Times (London), 17 April, p. 2. 
Weber, Thomas. 2003. 'Nonviolence Is Who? Gene Sharp and Gandhi'. Peace and Change 28: 250-270.

Williams, Betty and Mairead Corrigan. 1977. 'Nobel Lecture, December 11, 1977'. https://www.nobelprize.org/nobel_prizes/peace/laureates/1976/ williams-lecture_en.html.

Wimmer, Andreas. 2008. 'The Making and Unmaking of Ethnic Boundaries: A Multilevel Process Theory'. American Journal of Sociology 113: 970-1022.

Woehrle, Lynne M., Patrick G. Coy, and Gregory M. Maney. 2008. Contesting Patriotism: Culture, Power, and Strategy in the Peace Movement. Lanham, MD: Rowman \& Littlefield. 



\section{Afterword}

Social Movements, Long-term Processes, and Ethnic

Division in Northern Ireland

Joseph Ruane and Jennifer Todd

\section{Introduction: Social Movement Theory and Research on Northern Ireland}

Northern Ireland is a deeply divided society. The divisions, however, are socially and spatially uneven and their intensity varies over time with individuals swaying from relatively liberal and permeable views to deeper polarization and back again. John Whyte (1991) documented this for the 196os and 1970s and it is still the case today (Ruane 2017). Even at the height of communal polarization the division was never complete: there were individuals and subgroups who ignored it and seemed immune from antagonism, and local areas where mixing continued in the midst of violence.

The basis of division is also diverse. It has ethnic, national, religious, and colonial dimensions and its logic is not reducible to any one of these. It is not 'an ethnic conflict' or 'a colonial conflict', and still less a 'religious conflict', tout court. On the contrary, division persists and polarizes not because of one foundational element but because of the entwining of different cleavages in a context of power and inequality. As we have long argued, there are historically deep structures of power and inequality within the British-Irish archipelago, embedded in institutions and routinized practices in Northern Ireland which themselves embody overlapping and intersecting cultural differences, and which in turn produce and reproduce communities as emergent entities with richly layered repertoires of opposition (Ruane and Todd 1996, 2004, 2015). The communities are composite products of successive conjunctural confrontations during this long historical process. Contesting subgroups within each community may emphasize religion or nationality or colonialism, according to their particular ideological standpoint or interest, and each reproduces conflict between communities in the process of asserting their interests within them. Others - keeping themselves detached from conflict for the most part - retain links with those more directly involved by family, schooling, and neighbourhood which allows for future communal mobilization. If the emergent communities-in-conflict might be conceived as 'ethnic' communities, they are not ones defined by descent or 
by a common and continuous culture. They are rather constituted from the whole family of overlapping dimensions of difference, and the meanings and identities associated with division are themselves multiple and contested,.

There are structurally based tendencies for the culturally diverse dimensions of difference to converge in a continuity of division. But not all is structure or culture. There is also strategic action by individuals, political parties, economic and political elites, and groups of different size and level of organization. Some of this takes place in and through established institutions where - more often than not - it acts as a mechanism of structural and cultural reproduction. But there is also collective strategic action that brings pressure on the established institutions. The latter is the domain of social movements and it is this aspect of Northern Irish society and the Northern Irish conflict that engages the attention of Bosi, De Fazio, and their associates.

Starting from a view of ethnicity as an emergent property of social practice, Bosi and De Fazio draw on existing social movement theory and develop it in new ways. They engage at once with the contingency of movement choices and the unpredictability of movement outcomes, on the one hand, and with the underdetermining but nonetheless causally important structural conditions, on the other. These latter make some directions of collective mobilization more likely than others, and that shape the interactions between competing and conflicting social movements. These may generate new identities, interrelations and conflicts, reproduce existing ones, or renew older ones.

A range of scholars have highlighted the relational, temporal, and spatial situation of social movements, which are themselves rooted in longerlasting relations. Movements emerge and gain momentum in conjunctures where longer-term processes and unexpected events intersect, giving opportunities for change (Della Porta 2013; Bosi, Giugni, and Uba 2016; Bosi, Ó Dochartaigh, and Pisoiu 2015). Unlike the atheoretical event-oriented approach of many historians, or the party-system and actor-oriented approaches of many political scientists, or the synchronic structuralism of much sociology, social movement theorists concentrate in a fine-tuned manner on the ways in which actors from outside the mainstream political parties mobilize populations into powerful groups with the capacity to re-shape the political arena.

One of the key contributions of social movement theory to the study of ethnicity lies in its theory-mediated approach to understanding the making, unmaking, and remaking of ethnic divisions. It can explore the deeper context of resources and opportunities that lead ethnic mobilizations in unanticipated directions (see, for example, Hoewer 2015; Bosi and 
Davis, forthcoming). As such social movement theory has a key contribution to make to the task of situating successive critical junctures within a longer-term historical account of how 'ethnic' divisions emerge and become long-lasting, get unmade and remade. That said, many social movement studies focus on short-term, event-oriented processes, framed by middleterm institutional resources and take the deeper level structural processes as givens (Beissinger 2002).

The Northern Ireland case requires scholars to go beyond events and the middle-term to look also at the changing structural circumstances that condition the emergence and outcomes of social movements. In what follows we look at how social movement theory adds to our knowledge of Northern Ireland, where it could give still more insights, and where it might benefit from further broadening and contextualization. In conclusion, we suggest areas and questions where social movement studies might fruitfully focus its research.

\section{Broadening Theoretical Perspectives}

Recent work by social movement theorists like Della Porta, Bosi, De Fazio, and their colleagues represents an opening out of social movement studies to a broader relational, historical, and, indeed, structural context that converges with a historico-structural approach (see, in particular,Bosi, Ó Dochartaigh, and Pisoiu 2015; Della Porta 2013). Implicitly, if not explicitly, this work rests on a social ontology of practice: in Marx's terms, humans 'make their own history but not under conditions of their own choosing'. Historically situated practice over time produces its own constraints institutions, power structures, routinized habitus - which take on a pathdependent quality conditioning future practice in ways that are very hard to undo. From within this broad tradition, social movement theorists have emphasized the creative potential of collaborative agency, structuralists the constraints on it, and historical sociologists the path-dependent character of the processes involved. This is a division of labour where each can learn from the other.

From this perspective, the units of analysis - societies, conflicts, parties, movements, classes, ethnic groups - are complex entities constituted by intersecting global, regional, and local processes, whose properties vary with the precise timing and sequencing of the intersections. Rather than comparison that generalizes across abstractly conceived variables, or schematic ideal types as in the Weberian tradition, this approach reconstructs 
complex contextualized unities out of simpler elements and identifies their specific dynamic. Comparison comes in - as McAdam, Tilly, and Tarrow argue (2001) - by showing the differential impact of the same mechanisms and processes in different sequences and combinations.

For the study of ethnicity, this means a multi-level and multi-temporal approach. The very concept of ethnicity is an umbrella one encompassing a family of diverse phenomena (Ruane and Todd 2004). If short-term mobilization and framing highlights one set of divisions over others, middle term institution-building generates a set of routine practices and distinctions that makes some framings more plausible than others (Brubaker et al. 2006), while longer-term structural divisions and power imbalances are the context of successive rounds of state- and institution-building. If sometimes the result is radical discontinuity in the groups that come into conflict, in the Irish case the result has more often been continuity and persistence.

Bosi and De Fazio, and the authors they have brought together, correctly point out that the coherence and crystallization of ethnic groups in conflict is in part a product of successful social movements. They also show how these social movements build on and challenge embedded structural divisions, often with unanticipated consequences. They show the value of studying social movements in a deeply divided society like Northern Ireland. As the editors point out, it is a rich case for social movement theory that shows characteristics, trajectories, and patterns that are not so evident in more peaceful societies.

One of these patterns is the tendency of social movements in divided societies to generate continuity as well as change. As is well recognized in the literature, social movements may generate new alliances, aims, and identities through mechanisms of brokerage, object-shift, and framing, and bring change in institutions, power resources,power relations, and networks (McAdam, Tilly, and Tarrow 2001). But a new social movement may also be mobilized to confirm old alliances, aims, and identities and to prevent or reverse change in institutions and power relations. Even where it seeks change it may do so in a way that reinforces existing patterns and reproduces old divisions. The mechanisms by which longer-term patterns are reproduced in new contexts are far from adequately understood. The Northern Ireland case allows us to explore the social and cultural mechanisms which seem to 'lock in' division even in new contexts (Wright 1996; Ruane 2012). These mechanisms are of significance not just for deeply divided societies but also for the study of social change more generally, and the ways in which continuities are unintentionally reproduced (on institutional change, see 
Streeck and Thelen 2005; on identity change, see Rumelili and Todd 2017; on conflict, see Ruane and Todd 2015).

This means looking more closely at the relationship between movements/ politicians/publics in an effort to explain why some movements did and others did not gain support, why some metamorphosed to different aims and frames in mid-movement, and why the outcomes differed from the intent. This fruitful research agenda could only be increased by contextualizing the social movements in longer-term processes, including slow-moving demographic and power changes and showing how earlier movements at critical junctures in the past shaped these processes and redefined their direction.

\section{Contingency, Creativity and Continuity}

Bosi and De Fazio rightly point out that the ethnonational conflict and violence in Northern Ireland that characterized the period from 1969 to 1998 was far from determined by underlying structural conditions. And yet, it was far from contingent. This is an old conflict and a recurring one. Its conditions were put in place by conquest and the imposition and enforcement of inequality and maintained and sequentially reproduced despite continuing resistance. Settlement patterns, institutional structures, communication networks, class structures, and family structures underlay the persistence of division and made conflict likely to re-emerge in the future. The geopolitical context reproduced these conditions: division was a key mechanism through which Britain controlled Ireland.

The role of contingency in what happened in Northern Ireland in the late 1960 s has been well brought out by many of the authors in this volume in this and previous works. But 'pure' contingency is rare. If conflict and division have been underdetermined by structure, agency and contingency have operated within structural constraints. For example, Ó Dochartaigh and Bosi (2010) point to one of the ways in which the famous People's Democracy march in January 1969 served to crystallize community division for reasons that might seem contingent: the marchers slept overnight in the Catholic and republican villages of Toome and Bellaghy, rather than the Protestant and unionist villages of Castledawson and Knockloughrim. The decision was made because of already existing division: widespread, if uneven, local Protestant anger at the march meant it might be dangerous for the marchers to sleep in Protestant areas. Its outcome was massively to reinforce division so that it came to characterize the social movement itself: it cemented Catholic networks and friendships, increased the young marchers' openness 
to republican repertoires, and precluded local Protestant empathy with the students when they were later ambushed at Burntollet Bridge.

This volume takes the interplay of structure and contingency farther. It begins with a wide-ranging theoretical article by Bosi and De Fazio, which brings social movement theory in a direction that recognizes structural conditions while emphasizing their less-than-determining character and the need to look at the relational processes put in motion by contingent choices. This gives a full role to agency, and the creativity by which social movements can produce new processes and unexpected distinctions, while also recognizing the constraints on this creativity. A key issue is how, despite underdetermination by structure, the old divisions re-emerged. If 'contingency' is part of an explanation, the points at which there were alternative paths have to be highlighted and why these were not taken up explained.

Ó Dochartaigh (in this volume) is particularly relevant here. He emphasizes the bottom-up processes by which inequality is politicized. But he also emphasizes the continuity of themes within civil rights and anti-state movements over a quarter century. Enduring patterns of horizontal inequality, power, and state organization (particularly of the security forces) meant that successive anti-state social movements - though framed differently and with different activists and leaders - regenerated old demands and relations. Whether framed in civil rights or republican terms, whether peaceful or militarist, whether gathering together supporters on universalist, ethnic or republican grounds, and despite the often creative sequential reframing of the movements, the unintended consequence of challenge was continuity.

The balance of continuity and discontinuity - as Maney (in this volume) reminds us - is not simply a function of the Irish context. International processes intersect with civil rights mobilization and counter-mobilization, providing models and authoritative framing in the international media. These framing processes, themselves developed in a wider conflictual context, find partial parallels and homologies in Northern Ireland and define and strengthen those parallels: they partially create the conditions (the change from a civil rights movement framed as universalistic and open to one linked to republicanism and framed as particularist and violent) that they describe.

The process and outcomes of the civil rights mobilization were affected not just by the civil rights movement or the media, nor even by loyalist counter-mobilization, but by the political choices made by unionist and British governments. These choices were structurally circumscribed and, to a degree, overdetermined. They provided the opportunity structure for the movements and the incentives for activists to focus their attention on the 
unionist regime rather than simply its policies, and later to refocus attention on the British state rather than simply on the unionist regime. Turner and De Fazio's chapter on unionist Minister for Home Affairs William Craig shows that his actions need to be seen in a much broader context. Turner and De Fazio show that the actions appear irrational and, indeed, formed by 'ideological and emotional' responses. Yet, their chapter also suggests another hypothesis, that his actions may take on a more rational aspect if fully contextualized within unionism. Was Craig intuitively attempting to mobilize a wider swathe of unionist support behind the government and avoid the splits in unionism that followed - a policy that failed but was far from irrational? And was there any unionist governmental response that could have reconciled the demands of the civil rights campaign and the unionist imperative of saving the unionist-dominated state? Bosi and De Fazio (in this volume) imply there was such an option, even it is difficult to articulate how it might have worked out.

\section{Agency and Constraints on Agency}

The articles describe the multiple and intersecting social movements within Northern Ireland in the last half century. The contest between the opposing frames put forward by the different social movements becomes more and more striking and compelling as one reads through the book. Peace People, socialists, LGBT activists gave alternative cognitive schema for understanding Northern Ireland, as did the civil rights movement itself. So, too, did movements which worked from the traditional divisions. Republican prisoners worked collectively and tirelessly to get their story across to the wider public and to control public reception of it: to reframe state control as brutal repression, the modern prison system as equivalent to Calcutta, and the prisoners as fragile and suffering humans (O'Hearn, in this volume). Their local audience was Catholic and nationalist, but their methods were general. O'Hearn's account highlights the contrast between their innovative strategy and the rather traditional images they disseminated (their 'Don't Let My Daddy Die' poster was widely distributed during the hunger strikes). Republican feminists were attempting simultaneously to mobilize the wider (Catholic and nationalist) society for the republican project while mobilizing republicans on feminist lines and highlighting issues - LGBT - that potentially would allow later broadening beyond the traditional support base (O'Keefe, in this volume). All of this republican activity was highly creative. 
It was also contested within the movements, and particularly within republicanism. The 'dissidents' - later framed as those who left the republican fold - were on their own account those who were at the centre of republicanism and held to its core views (White and Demirel-Pegg, in this volume). The chapters by O'Hearn, O'Keefe, and White and Demirel-Pegg show how those struggling within the republican movement used a whole range of social movement mechanisms both for the struggle within the republican organization and support base, and in addressing a wider public. This is a paradigmatic case of within-movement contest and change.

The trajectory of unionist mobilization was very different. It had mobilized a great swathe of the Northern Protestant population at the start of the twentieth century. The great Unionist defining moment was over by 1921, and its institutionalization in Northern Ireland was well under way. The unionist political leadership came out for each year's ritual celebrations, but it was primarily loyalists - in the Orange Order and the hard-line working-class organizations - who participated in the parades and kept the engine of unionist mobilization ticking over. The engine was upgraded after 1968 in response to the civil rights movement, the IRA's campaign, and the attempt by the British government to establish power-sharing. Their mobilization was framed within the achieved unionist order, and intended to confirm and harden it against subversion: as Campbell (in this volume) notes, they appealed to the past, not just to the Ulster Covenant of 1912 but also to the seventeenth-century defence of the Protestant Crown and to the (working-class) Apprentice Boys of Derry who shut the gates against the Catholic King James (Buckley and Kenny 1995). This was a tradition that they repeated as much as remade: there was no loyalist feminist movement to challenge loyalism's internal structure, nor did loyalist prisoners remake loyalism on the outside. The young men who joined loyalist paramilitary organizations did so because their inherited belief systems and cognitive schema were challenged by events and by the intensity and persistence of republican violence (Ferguson and McAuley, in this volume). Some of them later challenged these ideas. But there was and is less dissent, less of a ferment of ideas, in loyalism than in republicanism or nationalism. As a movement defending a given power structure, albeit from a position of class assertion, there was less room for such debate.

In previous work, McAuley (2016), like Campbell (in this volume), points out the processes and habits that led working-class Protestants and loyalists to accept their tradition: solidarity, community, history, culture, and conflict. He is right that these were weighty motivations. But there were other options: those offered by the communists and trades unionists, Labour 
and Alliance Party supporters, and the range of religious and cultural and cross-community activists who lived and organized in these local areas (Munck and Rolston 1987; Smithey 2011; Smithey, in this volume). Though these groups always provided a counterpoint to the different strands of loyalism, they never seriously challenged it.

That pattern seems to be continuing. Working-class loyalists, teenagers, as well as those with experience of past conflict, recently remobilized in a loyalist protest against restrictions on the flying of the British flag from Belfast city hall (Nolan et al. 2014). The explanation needs to go beyond simply working-class loyalism. Rather, the explanation goes back to that earlier critical juncture at the start of the twentieth century where unionism was crystallized as the dominant force in the north-east of Ireland and organized itself politically to ensure its own solidarity and survival. At its core was a class contract between the unionist elite and the Protestant working class, which integrated the latter into the state and gave them a role in public policy. The new political order diminishes that role. The flags crisis marked loyalist insistence on maintaining the contract, and the unwillingnessof the Unionist Party elites fully to break it (Nolan et al. 2014; Tonge et al. 2014).

This volume shows in fascinating detail the differential patterning of social movements in Northern Ireland. The articles take us closer to the goal of explaining the diverse logics of mobilization and of success in this. If they do not all explicitly problematize the differentiation of choices, the uneven success, and the asymmetrical demands and organization of the movements, they give us much of the material we need to do so.

Bosi, De Fazio, and their contributors have focused on the agency of social movements and of the politicians they address. A further step - although this may push social movement theory to its limits - is to analyse the agency of the public who receive the competing social movement claims. It is here that what is often called 'ethnicity' (what we would see as a patterned concatenation of highly varying values, beliefs, solidarities, dispositions, and interests) weights public choices. In some cases, as in loyalist neighbourhoods, the weighting seems strong, persistent, and continuous, although this is occasionally disrupted (see Smithey, in this volume; Smithey 2011). The dynamic here is one of political as well as intellectual interest.

\section{Cross-cutting Alternatives}

There were - and are - alternatives to the varieties of unionism and nationalism. Northern Ireland was always awash with social movements, incipient 
social movements, and attempted movements of all sorts, each proposing its own cognitive schema for understanding Northern Ireland and its place in the world. Some of these intermittently gained very significant public support, most importantly the Peace People of the 1970s (Smithey, in this volume). There has also been a wide range of socialist movements, some cross-community organizations (the Alliance Party), and more recently ecological and LGBT mobilization (Nagle, in this volume). There were other movements again: Christian and post-Christian networks; the campaigns for equal citizenship, to save Ulster from sodomy, for abortion rights; organizations led by Protestant dissenters or by non-violent and non-provisional republicans; peace organizations like Corrymeela; community education projects like Conway Mill that took a quasi-movement form; music enthusiasts - punks - who thought of themselves as forming networks alternative to the main division; one-time activists partially retired but ready to join new movements (see Mitchell and Ganiel 2011; Finlay 2011).

Nagle and Smithey remind us, in their respective chapters, of the scope and potential of these movements, their significant public support, and their successes in organizing. Yet, not only did they fail to displace the varieties of unionism and nationalism, the most ambitious of them - the Peace People - collapsed. Smithey explains the failure: a too ambitious peace philosophy framed at a global level that failed to connect with wider public interests and expectations. His previous work (Smithey 2011) might suggest a further explanation: the lack of (publicly funded) arenas and locales and ritual practices where this movement might have flourished and gained more support. Timing was important: there were fewer opportunities for change in the $1970 \mathrm{~s}$ than in the late 1980 s and 1990s after the Anglo-Irish Agreement had opened British-Irish relations and the new equality legislation began to take effect.

Smithey and Nagle give us important information about the activists in these movements. But we know relatively little about the people who at least temporarily showed interest in and support for them, even if they later fell away. Were they past unionist or nationalist voters or the politically unaligned? Were they ex-civilrighters, or one-time Ulster Workers' Council strikers? Were they new generations wanting something different? Were they stay-at-homes or garden centre enthusiasts, previously unmobilized, who came out briefly to show their support? Or were they the individuals - of every politics and none - who routinely attended political meetings through the Troubles and always spoke up? Did those unionists and nationalists who privatized out of disappointment, loss of hope of change, come back again with a different vision, or did they, when they came back to vote or to march, simply return to the positions of the past? How did the support base 
of these alternative movements differ and did it affect the outcome? Why did the intermittent support for some of these movements subsequently fall away, and could it have been held onto? Here the new-generation social movement theory exemplified in this volume has much to contribute, not least in showing how the networks formed at one stage of mobilization helped or hindered new and alternative movements.

\section{Beyond Social Movement Theory}

Social movement theory, as this volume illustrates, can contribute much to the analysis of Northern Ireland and other divided societies. It also has greater potential: to address issues in general social theory in and through its deeper exploration of particular social movements.

It is a truism that periods of social crisis offer unique insights into the social world because for a brief moment the veil that obscures its operation is pulled aside. The study of social movements offers a strikingly similar potential. Social movements involve a deliberate, collective attempt to challenge the status quo, to which those who uphold it respond with varying degrees of resistance. The manner in which each goes about this can be a major source of insight into the workings of the social and political order, the functioning of its institutions, the resources and mechanisms of power and the interests it serves, the norms, values and aspirations of the powerful and the powerless, the values and attitudes of the wider populations.

Social movement theorists typically engage with their subject matter at close quarters and often in microscopic detail. They look at what change is sought and why; who the activists are and what their background is; the choices they make and why they make them; why they pursue this goal rather than that one, and why in this way rather than another; how they attempt to recruit support and on what they base their appeal; the responses of the power-holders and the methods they use; why some movements succeed, or succeed for a time, while others fail, absolutely or by losing their radical potential; how much movements achieve and what they do not achieved.

Very often social movement theorists do not go much beyond the empirical details of the case they study, its immediate societal contextualization, and its similarities or dissimilarities with other cases. This is a lost opportunity. The insights gained from the study of social movements are directly relevant to the workings of the social at the highest level of generality: the forms of social life, how power operates and when and why it may cease to be effective, the different layers of the historical, the manner in which they 
intersect and converge in the present, the formation and interplay of interest and identities, the role of structure and contingency in social life, the role of actors in history, and whether they are determining or determined.

Historians go to great length to stress the infinite openness of events in history before they happen. Social theorists write of changes over time as if the particular and the contingent hardly matter: everything seems already inscribed in abstract social forms which presuppose and predetermine the outcome. Though they rarely do so, social movement theorists are uniquely positioned to break down this dichotomy, not least because this is also the enterprise that social activists are engaged in, whether consciously or unconsciously. Activists, too, make decisions on what was possible before and what is possible now, what goals it is reasonable to pursue, who can usefully be appealed to and on what grounds, what layers of the social to try to tap into, whether they are working with or against the 'grain of history', whether this is a unique historical juncture that can be intervened in, what reference to make to the past and how to interrelate it with the present. They are buffeted and frustrated by hostile events they did not anticipate, and are quick to exploit unanticipated opportunities, knowing that the goals they pursue must have deeper roots than what is provided simply by contingent events. By reflecting on their actions and outcomes, social movement theorists are in an excellent position to engage in the more general debates.

In this context the Northern Ireland case - and the island of Ireland more generally - is of exceptional interest, not simply because for more than two centuries change has repeatedly been driven by processes of social and political and cultural mobilization, but because of the complexities and ambiguities of its history. Its divisions are complex composites rather than unitary phenomena, both emergent and long-lasting, persistent and always in process of being unmade and remade, both underdetermined and, from another angle, overdetermined, and open to tracking in temporal sequences that are simultaneously long, middle, and short term. In this context, the detailed study of particular social movements always involves taking a stance on more general historical and wider theoretical issues.

The Northern Ireland civil rights movement and the nationalist mobilizations that followed invite such reflections on the longer historical process and its general theoretical implications. As this volume shows, the civil rights movement offers immense scope for social movement analysis. It also invites further questioning as to its timing, form, and outcome. That particular movement - and Protestant responses to it - can be fitted into a long history of Catholic pressure group politics and Protestant responses that goes back to the eighteenth century. Was the civil rights movement something truly new, 
or simply the old in new guise? The question, raised by the actors themselves, is theoretically relevant. Successive mobilizations are related to shifts in the balance of Catholic-Protestant demographic and economic power (Ruane and Todd 1996), but the interrelation of these structural conditions with particular events and contingent decisions demands theoretical attention. Was a challenge inevitable and only the particular form contingent? This might explain why a rights-based Catholic mobilization did not emerge in (say) the 1920 s and 1930 s when aggrieved minorities all over Europe were protesting and claiming rights, and instead emerged in the 196os, able then to take the example of the 1950s and 196os Civil Rights Movement in the United States. But even this may imply too much determinism. If some challenge became likely in the post-war period, might it have been neutralized by political reform? This raises the further question of why egalitarian reformist unionism was so weak. The questions are alluded to but not fully addressed by Bosi, De Fazio, and the other contributors.

Then there is the question of why the civil rights movement was so quickly followed by non-violent nationalist and violent republican mobilizations. Were these extensions of the earlier movement, or distinct and separate movements that opportunistically exploited the crisis created by the civil rights movement and the unionist response to it? Are these entirely separate strands - a reasonable conclusion given the tendency of the adherents of each to denounce the other - or are they interwoven strands with the same structural basis? Or - more plausibly again - would a more differentiated structural approach which points to the intersection of class, religious, and other cleavages allow us to show the overlapping basis of these movements?

The point of asking these questions is to highlight issues of theoretical significance which need to be addressed explicitly rather than embedded in implicit assumptions. To answer them requires judgement on the relative weight of different structurally based tendencies, probabilities, and degrees of chance. It requires an engagement with fundamental questions about the history of the island of Ireland - not least its history of conquest, colonization, and religious wars - and the social and political structures and communal divisions that emerged as a result of it. This means locating social movements in their wider geo-political context and the role of the British and more recently Irish states in manipulating opportunities and incentives.

The role of the colonial dimension in the British-Irish relationship is far from simple. Has it generated a 'grain of history' that has stubbornly asserted itself, despite all attempts to block it or circumvent its effects? Or is this simply nationalist ideology? Any argument framed in terms of the 'grain of history' needs to show the mechanisms through which it operates. Here 
the detailed analyses of social movement scholars are of great relevance. Equally, to highlight the more general questions is to encourage social movement research to move beyond simple assumptions about the 'ethnic' agents mobilized or mobilizing, and to problematize the processes by which continuities are reproduced. As the new generation of social movement scholars explores such movements in their context and spatio-temporal relations, they encounter basic questions of social theory and of the application of theoretical concepts to 'actual societies' including what - if anything - it means to talk in terms of 'Irish society' or 'Northern Irish society'. The strength of social movement research comes from its detailed knowledge of particular cases and particular processes. It is time for social movement theorists to bring this knowledge to bear on wider questions.

\section{Works Cited}

Beissinger, Mark R. 2002. Nationalist Mobilisation and the Collapse of the Soviet State. Cambridge: Cambridge University Press.

Bosi, Lorenzo, and Donagh Davis. Forthcoming. “What Is to Be Done?": Agency and the Causation of Transformative Events in Ireland's 1916 Rising and 1969 Long March'. Mobilization.

Bosi, Lorenzo, Marco Giugni, and Katrin Uba, eds. 2016. The Consequences of Social Movements. Cambridge: Cambridge University Press.

Bosi, Lorenzo, Niall Ó Dochartaigh, and Daniela Pisoiu, eds. 2015. Political Violence in Context: Time, Space and Milieu. Colchester: ECPR Press.

Brubaker, Rogers, Margit Fleishschmidt, Jon Fox, and Liana Grancea. 2006. Nationalist Politics and Everyday Ethnicity in a Transylvanian Town. Princeton: Princeton University Press.

Buckley, Anthony D., and Mary C. Kenny. 1995. Negotiating Identity: Rhetoric, Metaphor and SocialDrama in Northern Ireland. London:Smithsonian Institute Press.

Della Porta, Donatella. 2013. Clandestine Political Violence. Cambridge: Cambridge University Press.

Finlay, Andrew. 2011. Governing Ethnic Conflict: Consociation, Identity and the Price of Peace. London: Routledge.

Hoewer, Melanie. 2015. Crossing Boundaries during Peace and Conflict: Transforming Identity in Chiapas and in Northern Ireland. New York: Palgrave Macmillan.

McAdam, Doug, Sidney Tarrow, and Charles Tilly. 2001. Dynamics of Contention. Cambridge: Cambridge University Press.

McAuley, James. 2016. Very British Rebels? The Culture and Politics of Ulster Loyalism. London: Bloomsbury. 
Mitchell, Claire, and Gladys Ganiel. 2011. EvangelicalJourneys: Choice and Change in a Northern Irish Religious Subculture. Dublin: UCD Press.

Morrow, Duncan, Gillian Robinson, and Lizanne Dowds. 2013. 'The Long View of Community Relations in Northern Ireland: 1989-2012'. ARK Research Update 87. Belfast: ARK. http://www.ark.ac.uk/publications/updates/update87.pdf.

Munck, Ronald, and William Rolston. 1987. Belfast in the Thirties: An Oral History. Belfast: Blackstaff Press.

Nolan, Paul, Dominic Bryan, Clare Dwyer, Katy Hayward, Katy Radford, and Peter Shirlow. 2014. The Flag Dispute: Anatomy of a Protest. Queen's University Belfast. http://pure.qub.ac.uk/portal/files/13748797/The_Flag_Dispute_report_PRINTED.pdf.

Ó Dochartaigh, Niall, and Lorenzo Bosi. 2010. 'Territoriality and Mobilization: The Civil Rights Campaign in Northern Ireland'. Mobilization 15.4: 405-424.

Ruane, Joseph. 2012. 'Ireland's Ethno-religious Conflicts: Path Dependence and Its Legacies'. In At the Anvil: Essays in Honour of William J. Smyth, ed. P.J. Duffy and W. Nolan. Dublin: Geography Publications, 631-652.

Ruane, Joseph. 2017. 'Modelling Ireland's Crises: North, South, and North-South Intersections'. In Dynamics of Political Change in Ireland: Making and Breaking a Divided Island, ed. Niall Ó Dochartaigh, Katy Hayward, and Elizabeth Meehan. London: Routledge (forthcoming).

Ruane, Joseph, and Jennifer Todd. 1996. The Dynamics of Conflict in Northern Ireland:Power, Conflict and Emancipation. Cambridge: Cambridge University Press. Ruane, Joseph, and Jennifer Todd. 2004. 'The Roots of Intense Ethnic Conflict May Not In Fact Be Ethnic: Categories, Communities and Path Dependence'. European Journal of Sociology 45.2: 209-232.

Ruane, Joseph, and Jennifer Todd. 2015. 'Multiple Temporalities in Violent Conflicts: Northern Ireland, the Basque Country and Macedonia'. In Political Violence in Context: Time, Space and Milieu, ed. Lorenzo Bosi, Niall Ó Dochartaigh, and Daniela Pisoiu. Colchester: EPCR Press, 43-66.

Rumelili, B. and J. Todd. 2017 (forthcoming). 'Paradoxes of Identity Change: Macro, Meso, Micro Perspectives'. Politics.

Smithey, Lee A. 2011. Unionists, Loyalists, and Conflict Transformation in Northern Ireland. Oxford: Oxford University Press.

Streeck, Wolfgang, and Kathleen Thelen. 2005. Beyond Continuity: Institutional Change in Advanced Political Economies. Oxford: Oxford University Press.

Tonge, Jonathan, Máire Braniff, Thomas Hennessey, James W. McAuley, and Sophie A. Whiting. 2014. The Democratic Unionist Party: From Protest to Power. Oxford: Oxford University Press.

Whyte, John. 1991. Interpreting Northern Ireland. Oxford: Oxford University Press. 
Wright, Frank. 1996. Two Lands on One Soil:Ulster Politics before Home Rule. Dublin: Gill and Macmillan. 


\section{List of Authors}

Lorenzo Bosi is based at Scuola Normale Superiore.

Email: lorenzo.bosi@sns.it

Sarah Campbell is based at Newcastle University.

Email: sarah.campbell@ncl.ac.uk

Gianluca De Fazio is based at James Madison University.

Email: defazigx@jmu.edu

Tijen Demirel-Pegg is based at Indiana University-Purdue University Indianapolis.

Email: tipegg@iupui.edu

Neil Ferguson is based at Liverpool Hope University.

Email:FERGUSN@hope.ac.uk

Gregory Maney is based at Hofstra University.

Email: gregory.m.maney@hofstra.edu

James W. McAuley is based at the University of Huddersfield.

Email:j.w.mcauley@hud.ac.uk

John Nagle is based at the University of Aberdeen.

Email:j.nagle@abdn.ac.uk

Niall Ó Dochartaigh is based at National University of Ireland, Galway.

Email:niall.odochartaigh@nuigalway.ie

Denis O'Hearn is Head of the Sociology Department at Texas A\&M University.

Email:dohearn@tamu.edu

Theresa O'Keefe is based at University College Cork.

Email: theresa.okeefe@ucc.ie

Joseph Ruane is based at University College Cork.

Email:j.ruane@ucc.ie 
Lee A. Smithey is based at Swarthmore College.

Email:1smithe1@swarthmore.edu

Jennifer Todd is based at University College Dublin.

Email: jennifer.todd@ucd.ie

Erin-Beth Turner received her Master's Degree from Uppsala University. Email: erinbeth.turner@gmail.com

Robert W. White is based at Indiana University-Purdue University Indianapolis.

Email: spike@iupui.edu 


\section{Index}

Adams, Gerry 36, 133, 138-139, 151, 154-156, 178 Arthur, Paul 37

Bean, Kevin 21

Benford, Robert 72, 105, 209

Bosi, Lorenzo 38-39, 104, 112, 125, 224-232

Brubaker, Rogers 13

Cahill, Joe 134-143

Campbell, Sarah 24, 138, 230

Carson, Edward 98, 100, 102-106

Chichester-Clark, James 80

Cooper, Ivan 42, 45

Corrigan, Mairead 203-219

Craig, Bill 100

Craig, William 58-67, 77, 229

Currie, Austin 76

De Fazio, Gianluca 104, 112, 224-232

Della Porta, Donatella 14, 33, 125, 225

Demirel-Pegg, Tijen 24, 72-73, 166

Devlin, Bernadette 83, 166, 172, 178

Diani, Mario 14, 187

English, Richard 22

Eyerman, Ron 209, 215

Farrell, Mairéad 165, 172

Farrell, Michael 83

Faulkner, Brian 62, 78, 80

Ferguson, Neil 99, 106

Ferriter, Diarmuid 168

Fillieule, Olivier 112

Gandhi 210, 212

Harris, Frederick 91

Hughes, Brendan 151-158

Hume, John 45, 77, 178

Hunt, Scott 79

Irvin, Cynthia 20

Jamison, Andrew 209, 215

Maguire, Diarmuid 20

Maney, Gregory 23, 37, 46, 228
Martin, Greg 21

McAdam, Doug 45, 71, 216, 226

McAuley, James 24, 99, 106, 230

McCann, Eamonn 36, 83

McCauley, Clark 124

McGuinness, Martin 133-134, 138-139

McKeown, Ciaran 203-205, 207-209, 211-215, 217,219

McWilliams, Monica 174

Meyer, David 102

Morrison, Danny 138

Moskalenko, Sophia 124

Nagle, John 18, 25, 205, 218, 232

Ó Brádaigh, Ruairí 135-138, 140

Ó Dochartaigh, Fionbarra 76

Ó Dochartaigh, Niall 22-23, 57-58, 72, 227-228

O'Hearn, Denis 21, 24, 37, 138, 160, 229-230

O'Keefe, Theresa 24-25, 229-230

O'Neill, Terence 23, 54, 59, 61-62, 64-67, 79, 98

Paisley, Ian 58, 67, 100, 104, 113-114, 193

Purdie, Bob 22, 37

Sands, Bobby 151-158

Sewell, William 160

Shirlow, Peter 98

Smithey, Lee 17, 25, 186, 231-232

Snow, David 72, 96

Spence, Gusty 214

Tarrow, Sidney 72, 129, 226

Tilly, Charles 33, 94, 226

Turner, Erin 23, 44, 46, 72, 229

Viterna, Jocelyn 169

White, Robert 20, 24, 33, 72, 147, 166, 230

Whittier, Nancy 166

Whyte, John 37, 223

Williams, Betty 203, 205-209, 211-212, 215, 217, 219

Wilson, Harold 44, 6o-64, 79, 98 



\section{Protest and Social Movements}

James M. Jasper and Jan Willem Duyvendak (eds): Players and Arenas.

The Interactive Dynamics of Protest

2015, ISBN 9789089647085

Isabel David and Kumru F. Toktamış (eds): 'Everywhere Taksim'. Sowing

the Seeds for a New Turkey at Gezi

2015, ISBN 9789089648075

Johanna Siméant, Marie-Emmanuelle Pommerolle and Isabelle Sommier (eds): Observing Protest from a Place. The World Social Forum in Dakar (2011)

2015, ISBN 9789089647801

Robert M. Press: Ripples of Hope. How Ordinary People Resist Repression without Violence

2015, ISBN 9789089647481

Jan Willem Duyvendak and James M. Jasper (eds): Breaking Down the

State. Protestors Engaged

2015, ISBN 9789089647597

Christophe Traïni: The Animal Rights Struggle. An Essay in Historical Sociology

2016, ISBN 9789089648495

Mustafa Gurbuz: Rival Kurdish Movements in Turkey. Transforming Ethnic Conflict

2016, ISBN 9789089648785

Marcos Ancelovici, Pascale Dufour and Héloïse Nez (eds): Street Politics in the Age of Austerity. From the Indignados to Occupy 2016, ISBN 9789089647634

Johanna Siméant and Christophe Traini: Bodies in Protest. Hunger Strikes and Angry Music

2016, ISBN 9789089649331 
Kerstin Jacobsson and Jonas Lindblom: Animal Rights Activism.

A Moral-Sociological Perspective on Social Movements 2016, ISBN 9789089647641 